\title{
Menina Mulher da Pele Preta \\ Projeto de Série Televisiva que discute questões de Gênero e Raça ligados a Mulher Negra.
}

Universidade de São Paulo

Escola de Comunicações e Artes 
Programa em Pós Graduação em Ciências da Comunicação pela ECA/USP - PPGCOM.

\title{
Menina Mulher da Pele Preta \\ Projeto de Série Televisiva que discute questões de Gênero e Raça ligados a Mulher Negra.
}

\begin{abstract}
Dissertação apresentada ao Programa de Pós-Graduação em Ciências da Comunicação, Área de Concentração Estudos do Meio de Produção Mediática, Linha de Pesquisa Comunicação Impressa e Audiovisual, da Escola de Comunicações e Artes da Universidade de São Paulo, como exigência parcial para obtenção do Título de Mestre em Ciências da Comunicação, sob orientação da Prof. ${ }^{a}$ Livre Docente Esther Império Hamburger.
\end{abstract}




\section{Ficha Catalográfica}

\section{Catalogação na publicação \\ Serviço de Biblioteca e Documentação \\ Escola de Comunicações e Artes da Universidade de São Paulo}

Lima, Renato Candido de

Menina mulher da pele preta : projeto de série televisiva que discute questões de gênero e raça ligados a mulher negra / Renato Candido de Lima - São Paulo : R.C. Lima, 2011.

291 p. : il. + DVD

Dissertação (Mestrado) - Escola de Comunicações e Artes / Universidade de São Paulo.

Orientadora: Prof ${ }^{\mathrm{a}} \mathrm{Dr}^{\mathrm{a}}$ Esther Império Hamburger

1. Mulher negra 2. Série televisiva 3. Roteiro 4. Representação da periferia 5. Representação do negro 6. Audiovisual brasileiro 7. Dramaturgia audiovisual I. Hamburger, Esther Império II. Título 


\section{Comissão Julgadora}

Prof. ${ }^{a}$ Livre Docente Esther Império Hamburger

Prof. Dr. Rubens Arnaldo Rewald

Prof. ${ }^{a}$ Dr. ${ }^{a}$ Ana Paula da Silva

Esta dissertação foi julgada adequada à obtenção do título de Mestre em Ciências da Comunicação e aprovada em sua forma final pelo Curso de Mestrado em Ciências da Comunicação da Escola de Comunicações e Artes da Universidade de São Paulo.

São Paulo, de

de 2011.

Orientação: Livre Docente Esther Império Hamburger Instituição: Universidade de São Paulo

Professor: Prof. Dr. Rubens Arnaldo Rewald Instituição: Universidade de São Paulo

Professor: Prof. ${ }^{a}$ Dr. ${ }^{a}$ Ana Paula da Silva Instituição: Universidade de São Paulo 


\section{MANIFESTO DO OLHAR VISCERAL}

Sou viela, ciranda ou morro.

O corpo. As vísceras.

Reivindicando a alma sequestrada há mais de 500 anos.

O vídeo-artesão na linha de montagem feita de organismo vivo; gerado da necessidade de representar o universo que nos circunda.

O nosso vídeo se faz à imagem esculpida do puro caos ordenado no calor da noção de quem não só filma, mas se filma ao narrar sua própria história pela lente fria da câmera.

O olhar em desintoxicação!

Uma ofensa ao pobre cinema-manso, à mediocridade da novela nossa de cada dia.

Nossa estética é a da procura, a do resgate, a do encontro, da experimentação.

Olhar quilombola que ofusca e risca a imagem dos borba-gatos da colonização cultural.

Sabotagem na linha de produção e reprodução de estereótipos.

Celebração do personagem vivo, do personagem-alma, da periferia viva.

O encontro entre personagem, espectador e realizador, um na bolinha do olho do outro.

Em busca da cinemateca perdida criamos nossos cineclubes-avessos em bares, escadões, becos, nossas quebradas... 
Periferias como centro. Periferia do universo, do mundo, do país, da cidade, dialogando com nossos sentimentos.

E... nosso nome não é Zé Pequeno!!!!!!!!!!!!!

\section{CineBecos, NCA, Arte na Periferia, MUCCA}

(Coletivos Audiovisuais da Periferia Sul da Cidade de São Paulo) 


\section{SOU MULHER NEGRA E RESISTO!}

Sou Mulher negra e resisto!

Contra tudo que um dia me julgou incapaz

Contra o que um dia alegou que minha capacidade estava na cozinha

Que falou que minha sina era ser submissa

SOU MULHER NEGRA E RESISTO!

Contra a mídia, que tenta me prostituir.

Contra o embranquecimento sobre a minha negritude, tenha respeito!!! SOU MULHER NEGRA E RESISTO!

E graças á minha ancestralidade de mulheres guerreiras, tenho em que me apegar... Pois Carolina Maria de Jesus resistiu, mesmo passando fome não se rendeu ao dinheiro fácil.

E com sofrimento em meio ao papel que catava encontrou um caderno e uma caneta, e fez disso uma arma

Para denunciar toda miséria sofrida da favela...

Resistente como Luiza Mahin.

Que era princesa africana, lutou bravamente na revolta dos Malês, vendendo seus quitutes ajudava os irmãos com os recados que passava.

Resisto como a preta Anastácia

Que usou mordaça de ferro por ter rejeitado um "senhor branco" era bela, chamada de princesa nunca negou sua nobreza.

Resistente como mãe Menininha dos Gantoá

Pois sofreu repressão por praticar o candomblé... foi presa, perseguida...

Mas não deixou de executar a religião, era certa que o candomblé era o último meio de resistência e dignidade negra.

E como muitas outras mulheres negras resisto e resistirei!

Somos fortes, somos mais que guerreiras. 
Somos deusas...

Somos verdade, beleza, sutileza, fortaleza.

Somos história, e não lenda.

Por toda mulher negra, que lutou e resistiu hoje eu bato no peito e grito com verdade e pensamento convicto

EU SOU MULHER NEGRA E RESISTO!

Raquel Almeida - Sarau Elo da Corrente (Pirituba) 


\section{Agradecimentos}

Agradeço a minha família pernambucana que fizeram chão nesta terra paulista. Suas histórias Agrestes de lutas e de amor me fizeram possível na existência deste mundo e deste tempo.

Aos meus pais operários que desde os anos 60 sempre batalharam muito, mesmo num país e numa sociedade que, muitas vezes, não os levaram a sério.

Ao CineBecos, do qual faço parte, pelos grandes braços e mãos estendidas da Zona Sul para Zona Norte e vice-versa.

A Odun Formação e Produção, na figura de Viviane Ferreira da Cruz e Elcimar Dias Pereira que exercem seus protagonismos femininos na condução de uma empresa de produção e formação de cultura.

As pessoas que contribuem com seus poemas, poesias e contos nos Sarais da Cooperifa, Binho, Ademar, Brasa e Elo da Corrente; assim como os compositores em Sambas como da Vela, do Monte, de São Mateus. Agradecimento especial ao sambista compositor Marquinho Dikuã, do Jardim São Luís, Zona Sul de São Paulo.

Ao grupo teatral Capulanas - Companhia de Arte Teatral Negra, nas figuras das atrizes Adriana Paixão, Priscila Preta, Débora Maria Marçal e Flávia Rosa e a Companhia Teatral Clariô, especificamente às atrizes Naruna Costa, Martinha Soares, Naloana Lima e ao diretor da companhia Mário Pazini. 
Agradeço especialmente ao Giovani Di Ganzá, musicista afro-erudito; a Rogério Pixote, cineasta preto-periférico como eu; Elizandra Souza, jornalista poeta que me ofereceu seus contos para roteirização, Ana Paula dos Santos Risos, atrizescritora de quem roteirizei o conto "Estação de Transferência" e a Juliana Rodrigues Valente Santana Nunes, amiga de graduação na USP com quem sempre esteve junto ao compartilhar e desenvolver o filme "Jennifer" e suas oficinas decorrentes. 
"Sonhei ser cineasta pra re-escrever todo o roteiro" (Rocha, cantor/compositor Hip-Hop e poeta da Cooperifa). 


\section{Resumo}

Esta dissertação em mestrado consiste na construção dramatúrgica de um projeto de série televisiva que dialoga questões de gênero e raça atrelados a representação da pessoa negra no audiovisual brasileiro. "Menina Mulher da Pele Preta" é o nome desta série e ela desenvolve cinco histórias de cinco mulheres negras protagonistas de diferentes idades com suas cinco diferentes realidades sociais e contextos. Seu título dialoga com a música "Essa Menina Mulher da Pele Preta" composta pelo cantor/compositor Jorge Ben, músico negro de grande referência para cultura brasileira. Apresento como parte da dissertação, o episódio piloto "Jennifer" no DVD em anexo. Neste capítulo, conta-se a história de uma adolescente filha de mãe negra e pai branco (filha de mãe solteira) moradora de uma região periférica da Zona Norte de São Paulo. Os roteiros dos cinco episódios compõem a primeira parte da dissertação.

A criação da série parte de minha avaliação crítica sobre produções audiovisuais contemporâneas de grande visibilidade que retrataram espaços periféricos. Esta análise também compreende situações biográficas ocorridas comigo na relação entre periferia e universidade. Assim, com um texto ensaístico apresentado na segunda parte desta dissertação, eu me situo no debate contemporâneo sobre a política e a poética das expressões audiovisuais da periferia, de negros, para negros e sobre negros.

Esta dissertação dialoga com dois textos acadêmicos recentes: Da política a poética de certas formas audiovisuais, livre docência da Professora Livre Docente Esther Império Hamburger e A Periferia nas Séries Televisivas Cidade dos Homens 
e Antônia, dissertação da Cientista Social e Mestre em Ciências da Comunicação Ananda Stücker. Eles se inserem num amplo debate acerca da necessidade de projetos audiovisuais atentos ao dilema da representação do outro na periferia.

Palavras Chave: Periferia, Mulher Negra, Relações Raciais, Série televisiva, roteiro cinematográfico, dramaturgia audiovisual. 


\section{Résumé}

Cette thèse de master propose la construction dramaturgique d'une série télévisée qui parle de questions de genre et de race liées à la représentation audiovisuel brésilien du peuple noir. Menina Mulher da Pele Preta est le nom de cette série télévisée et elle développe cinq histoires de cinq protagonistes femmes noires de différents âges avec ses cinq différentes réalités sociales et contextes. La référence pour le titre de cette série télévisée est la chanson titre Essa Menina Mulher da Pele Preta écrit par le chanteur / compositeur Jorge Ben, un musicien noir de grande référence pour la culture brésilienne. J'introduis dans le cadre de la thèse, l'épisode pilote Jennifer sur le DVD ci-joint. Ce chapitre raconte l'histoire de Jennifer, une fille adolescente d'une mère noire et père blanc (fille de mère célibataire) qui vit dans un banlieu nord de la ville de São Paulo. Les scénarios des cinq épisodes comprenent la première partie de la dissertation.

La création de la série part de ma évaluation critique des productions audiovisuelles contemporaines qui dépeint très visible les espaces périphériques. Cet analyse comprend également mes situations biographiques dans la relation entre la périphérie et l'université. Ainsi, avec un essai présentés dans la seconde partie de cette thèse, je me situe dans le débat contemporain sur la politique et poétique audio-visuel des expressions périphériques des Noirs, pour les Noirs et sur les Noirs,.

Cette thèse repond à deux récents documents universitaires: La thèse $D a$ política e poética de certas formas audiovisuais, écrit par la professeur resident 
Esther Império Hamburger, et la thèse de master La périphérie dans séries télévisées Cité d'hommes et Antonia, de la Maîtrise en Sciences de la communication Ananda Stücker. Ils partent d'un large débat sur la nécessité de projets audiovisuels conscients du dilemme de la représentation de l'autre dans la périphérie.

Mots-clés: Banlieu, femmes noires, relations raciales, série televisée, scénario, dramaturgie audio-visuel. 


\section{Sumário}

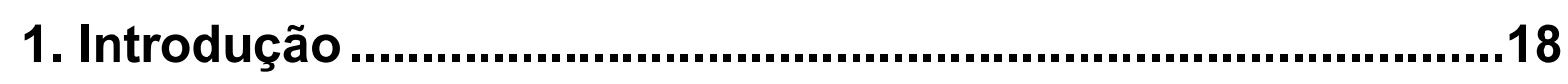

2. Roteiros de Menina Mulher da Pele Preta.............................26

2.1 Menina Mulher da Pele Preta - Episódio 1: Jennifer .................... 26

2.2 Menina Mulher da Pele Preta - Episódio 2: Larissa S/A ................59

2.3 Menina Mulher da Pele Preta - Episódio 3: Simone - Estórias em

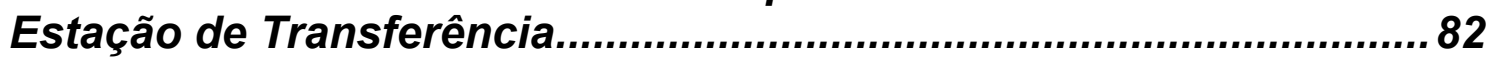

2.4 Menina Mulher da Pele Preta - Episódio 4: Dara - A Primeira Vez

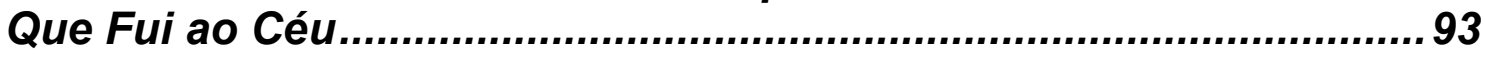

2.5 Menina Mulher da Pele Preta - Episódio 5: Deolinda ................. 104

3. Ensaio: Demolir para Construir ..........................................131

3.1 Metáforas com a Construção Civil. Demolindo para construir. 131

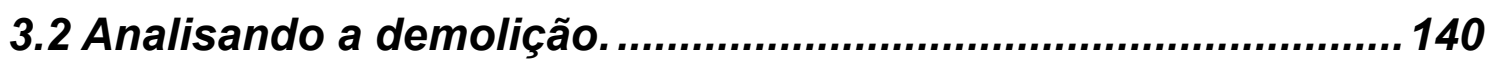

3.3 A Periferia sumiu no audiovisual atual? ..................................... 158

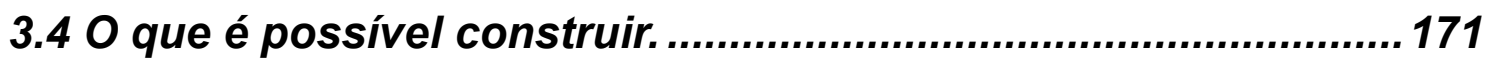

3.5. Audiovisual, Negro, Expressão, Representação, Universidade

Pública e Periferia. Problematizando a relação entre elas. .............. 176

3.6 Interlocução entre Periferia e Universidade............................... 219

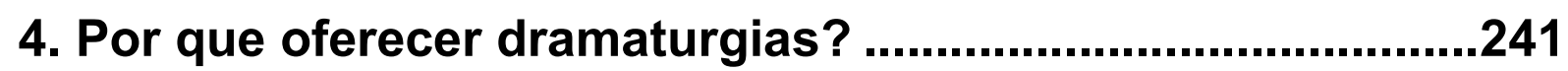

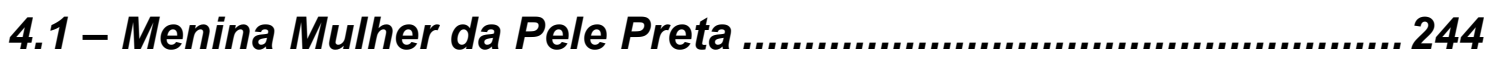

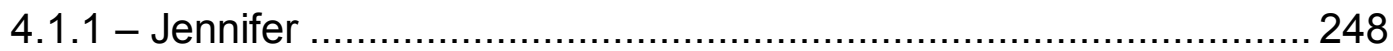

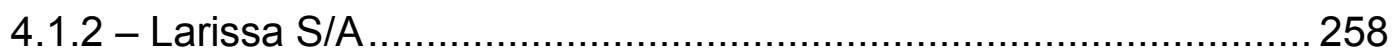

4.1.3 - Simone - Estórias em Estação de Transferência......................... 266

4.1.4 - Dara - A Primeira Vez que fui ao Céu ...................................... 269

4.1.5 - Deolinda ...................................................................... 2733 


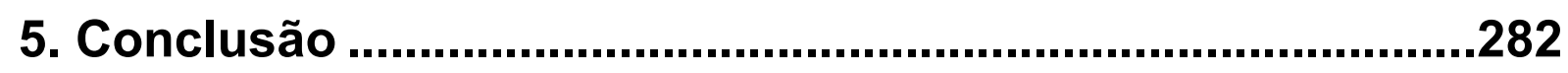

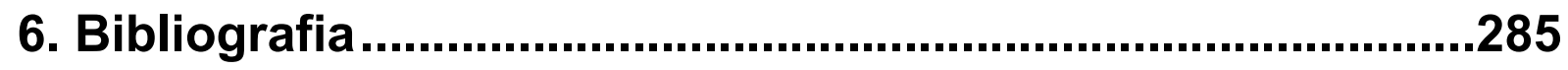

7. Referências Audiovisuais ..................................................288

8. Referencias Fonográficas .................................................291 


\section{Introdução}

Na primeira década do século XXI, houve inúmeras produções audiovisuais brasileiras que retrataram personagens e espaços periféricos através do cinema e da televisão. Alguns filmes desta vertente foram vistos por um grande número de espectadores como Cidade de Deus (2003, Fernando Meirelles) ou Tropa de Elite (2007, José Padilha). Estes exemplos geraram muitas discussões para além destas obras, permeando notícias telejornalísticas, discursos e críticas que inclusive se contrapõem aos retratos realizados nestes filmes, um exemplo disto foi o texto Cosmética da Fome ${ }^{1}$ de Ivana Bentes. Outros exemplos fílmicos não fizeram tantos espectadores no cinema como Uma Onda no $\operatorname{Ar}$ (2002, Helvécio Hatton) e Antônia (2006, Tata Amaral), apesar destas mesmas produções proporem retratar de maneira que pode ser considerada digna os espaços periféricos presentes nelas (não necessariamente apenas pelo viés da violência). Paralelamente a este contexto, muitos coletivos audiovisuais periféricos começaram a realizar suas obras em vídeo num intuito de dominar a linguagem cinematográfica/audiovisual e se colocarem como contraponto a representação da periferia na busca de formas de expressar este lugar e as pessoas que moram nela de maneira que ajudem a desarticular preconceitos e estereótipos ao invés de reforçá-los.

Filmes como Cidade de Deus e Tropa de Elite propuseram dramaturgias audiovisuais que situam nos bairros periféricos o espaço protagonista da violência das

1 No artigo "Da Estética à Cosmética da Fome", Jornal do Brasil, julho de 2001, a pesquisadora de cinema Ivana Bentes defende que há, no cinema nacional, uma retomada dos temas do Cinema Novo como a miséria e a violência, não como forma de denúncia social para desmascarar a sociedade brasileira como acontecia neste Cinema brasileiro dos anos 60, mas como uma "Cosmética da Fome", na qual miséria e violência são espetacularizadas para entreter e surgem de forma folclorizadas, paternalistas, conformista e piegas. 
grandes metrópoles brasileiras. Basicamente nestes filmes, a violência retratada acontece, nasce e se cria em espaços identificados como periferia (favela, subúrbio, quebrada, perifa). Os protagonistas destes filmes, habitantes destes lugares, são freqüentemente homens negros. Já em filmes como Uma Onda no Ar ou Antônia, os(as) protagonistas vencem batalhas cotidianas e superam algumas das muitas carências que imperam em espaços periféricos (como ausência de políticas públicas efetivas, falta de oportunidades, falta da presença do estado, etc). Por outro lado, produções de coletivos audiovisuais periféricos como o Filmagens Periféricas da Cidade Tiradentes, por exemplo, trabalham o espaço periférico não somente como sinônimo de violência; há nas realizações desses coletivos um desejo frequente em retratar a periferia e as pessoas que moram nela como protagonistas em diversos sentidos. Se analisarmos as obras que retratam periferia e aquelas protagonizadas por pessoas que estão nela, iremos constatar diversos elementos que evidenciam disputas sobre as formas de abordar esses espaços metropolitanos. Essas disputas reproduzem as desigualdades sociais no que tange, por exemplo, ao não equilíbrio de acesso a aparatos cinematográficos; desde o equipamento e o treinamento necessário a obtenção de qualidade técnica de imagem e som, até o acesso a formas de distribuição, fato que acirra ainda mais neste confronto.

Nas produções audiovisuais televisivas de maior visibilidade que retrataram espaços periféricos como as séries televisivas Cidade dos Homens (Rede Globo, 2003 a 2006), Antônia (Rede Globo, 2006 a 2007) e Turma do Gueto (Rede Record, 2002 a 2005), os protagonistas são negros e negras. Entenda-se produções audiovisuais de maior visibilidade como aquelas que mobilizaram ou mobilizam um intenso aparato de produção (como número de personagens, locações, trabalhadores) e são financiadas 
por Lei do Audiovisual ${ }^{2}$ ou mesmo pelo mercado televisivo. O fato de haver negros protagonistas nestas produções mostra uma mudança no audiovisual brasileiro uma vez que, como bem demonstrou o doutor em ciências da comunicação e cineasta Joel Zito de Araújo no livro e documentário $A$ Negação do Brasil, em que ele revela a histórica invisibilidade ou então estereotipia das representações do homem negro e da mulher negra na televisão brasileira

Em sua obra, Joel Zito Araújo analisa a presença e a qualidade dos(as) personagens negro(as) nas telenovelas brasileiras no período entre a década de 60 (1961-1970) até a metade final dos anos 90 (Até 1997, mais precisamente). Ao rever historicamente os personagens negros representados nas telenovelas, Joel Zito conclui que dentro das articulações entre invisibilidades e visibilidades de personagens negros, frequentemente a eles estão designados representações de estereótipos ou de inserção através de um processo de embranquecimento, mas ele aponta para um amadurecimento da sociedade, que torna possíveis produções em que o protagonismo dos afro-brasileiros seja evidente. No ínterim de sua argumentação na obra, há uma reiteração do que significa "ser branco como regra", ou seja, daquilo que significa branco representar o normal, o corriqueiro, a representação do humano por excelência.

A análise de Joel Zito não chegou até a primeira década do século XXI quando houve um grande número de obras audiovisuais que retrataram periferia nos quais

2 - A Lei do Audiovisual se trata da Lei Federal 8685/93, que regulamenta modalidades de investimento na produção e co-produção de obras cinematográficas e audiovisuais e infraestrutura para produção e exibição. A edição desta lei foi feita em 20 de julho de 1993. Prevista originalmente para vigorar até o exercício fiscal de 2003, esta lei foi prorrogada por mais 20 anos por meio da medida provisória $n .^{\circ} 2.228 / 01$, daquele mesmo ano. A Lei do Audiovisual permite que o investimento seja até $100 \%$ dedutível do Imposto de Renda (limitado a $4 \%$ do IR devido, para pessoas jurídicas) e o desembolso pode ser deduzido como despesa operacional excluindo o valor investido no LALUR reduzindo a base de cálculo do próprio IR e do adicional do IR. 
seus protagonistas são majoritariamente negros; mas partindo do que ele realizou, cabe compreender quais as qualidades atribuídas e trabalhadas nos retratos destes protagonistas negros nas produções audiovisuais de maior visibilidade que retrataram espaços periféricos. Será que elas também circularam pelas estereotipias e reiteraram um jeito branco de ser como normativo ou civilizado? Como personagens negros, quais significados atribuídos e trabalhados nestes protagonistas?

Analisando obras audiovisuais recentes de grande visibilidade que retrataram periferias, percebe-se a presença majoritária de protagonistas negros, fato que poderia corroborar a hipótese lançada por Joel Zito ao relacionar a evidencia de protagonistas negros com um amadurecimento da nossa sociedade. No entanto, este protagonismo negro ainda é pouco discutido se relacionarmos a invisibilidade e/ou a estereotipia do negro e da negra no audiovisual brasileiro em corpo e em história. Ou seja, as discussões que permeiam tensões raciais aparecem às vezes como embates eventuais e não como caráter intrínseco da relação entre aquilo que significa branco e o negro na nossa sociedade. Não obstante, é também frequente a violência ser validada como forma e expressão intrínseca ao homem negro. No caráter de se trabalhar as questões raciais por embates eventuais, pode se perceber isto, por exemplo, no capítulo Uóloce e João Victor da primeira temporada da série televisiva Cidade dos Homens. O episódio conta a história de uma relação entre dois adolescentes, um branco de classe media (João Victor) e um negro pobre (Uóloce), João Victor em sua imaginação chama Uóloce de racista, mas dificilmente na nossa sociedade a prática do racismo partiria de quem historicamente sofreu o exercício desta discriminação.

Ao que parece, a presença protagonista do corpo e do rosto negro nas obras 
audiovisuais que retratam periferia acontece muitas vezes como fato dado e encerrado como um dos alicerces para se legitimar aquilo que acontece no espaço periférico. A periferia é caótica e nada melhor que negros para representá-la, assegurando-se assim a necessidade de se criar este OUTRO negro e assegurar este lugar onde ele sempre habitará. Neste sentido, o texto “As Formas Africanas de Auto-Inscrição" do filósofo e sociólogo camaronês Achille Mbembe traz uma interessante interpretação crítica sobre os diversos essencialismos construídos em torno de uma suposta leitura pan-africana e consensual do mundo; Achille alerta para os perigos advindos da busca irrefletida de uma alteridade africana sem o devido reconhecimento das especificidades culturais, políticas e geográficas na África. Esta análise serve como advertência em relação a possíveis essencialismos ligados a representação do negro nas periferias urbanas brasileiras.

Para que se possa entender as implicações políticas destes debates, talvez eu deva assinalar que, para o pensamento iluminista, a humanidade se define pela posse de uma identidade genérica que é universal em sua essência, e da qual derivam direitos e valores que podem ser partilhados por todos. Uma natureza comum une todos os seres humanos. Ela é idêntica em cada um deles, porque a razão está em seu centro. O exercício da razão leva não apenas à liberdade e à autonomia, mas também à habilidade de guiar a vida individual de acordo com princípios morais e com a ideia do bem. Fora deste círculo, não há lugar para uma política do universal...

...Em outras palavras, seria possível encontrar, entre os africanos, o mesmo ser humano, apenas disfarçado sob diferentes formas e designações? Poderíamos considerar os corpos, as línguas, o trabalho e a vida africanos como produtos de uma atividade humana, como manifestações de uma subjetividade - ou seja, de uma consciência tal como a nossa - de forma a permitir que os consideremos, a cada um deles individualmente, como um alter ego (um outro eu)? (Mbembe, 2001, p.177)

Situando esta análise no nosso contexto sobre periferia, será que na relação que se estabelece entre centro(s) e periferia(s), as obras audiovisuais de maior 
visibilidade que retrataram a periferia ressaltam formas de inadequação da população que vive nela na nossa sociedade? No nosso caso, a natureza comum que une a todos no nosso país é uma essência naquilo que significa o branco por excelência? A visibilidade e o protagonismo dos rostos e corpos negros no retrato de espaços periféricos, sejam eles vistos de maneira positiva ou negativa, relacionam-se à reprodução de desigualdades históricas?

Como mestrando, roteirista, negro e realizador audiovisual periférico; percebi que para encarar estas questões, primeiramente seria importante compreender esta distância mediada pelo lugar da periferia aliada à representação do corpo e do rosto negros. Entendi que o desafio não estava em apontar novamente o que falta em obras audiovisuais como Cidade de Deus, Cidade dos Homens, Turma do Gueto, Antônia, etc; mas sim está naquilo que eu posso propor como dramaturgia e produção também audiovisuais. Neste contexto, nasce nesta dissertação a proposta dramatúrgica audiovisual: "Menina Mulher da Pele Preta". Na série, seus objetivos percorrem os seguintes pontos:

1 - Problematizar como as discriminações são praticadas quando se há um contexto ou condição de igualdade social entre brancos e negros. Apontando para exercícios de branquitude na nossa sociedade.

2 - Observar a persistência e a atualidade de uma ideologia embranquecedora ou olhar embranquecedor que permeia o desejo de ascensão social pela via econômica ou educacional da pessoa negra ou mulata. 
3 - Abordar maneiras pelas quais o sujeito negro e mulato negocia sua branquitude e sua negritude em determinados lugares, situações e contextos.

4 - Problematizar os estereótipos convencionais ligados à mulher negra, frequentemente invisibilizada ou tratada como exótica em representações audiovisuais.

5 - Pesquisar uma dramaturgia audiovisual em formato de série televisiva que dialogue e problematize vários significados atrelados ao imaginário sobre o homem negro e a mulher negra em nossa sociedade.

6 - Proporcionar em "Menina Mulher da Pele Preta" uma importante contribuição dramatúrgica na representação de mulheres negras no audiovisual brasileiro.

7 - Problematizar questões sobre o retrato do negro em nosso audiovisual e relacionálas a literatura antropológica e sociológica que aborda questões acerca do pertencimento do negro na nossa sociedade.

8 - Ser em "Mulher da Pele Preta" um exemplo de discussão afirmativa sobre o papel e a presença do que significa o negro, a pessoa negra, em nossa sociedade.

9 - Possibilitar um novo olhar acerca dos espaços periféricos e as pessoas que moram neles.

Como comumente um Roteiro Cinematográfico é uma peça com estrutura diferente da dissertação em si, para conciliar os roteiros desenvolvidos neste processo 
com os textos desta dissertação, eu trago o seguinte caminho: Primeiramente contextualizo o ponto de vista desta dissertação e seus objetivos através deste capítulo introdutório. Depois, trago os roteiros desenvolvidos para os cinco capítulos desta série, a ideia é que eles tragam o tema por si. Logo após as dramaturgias, elaboro um ensaio que serve de base aos questionamentos colocados nos roteiros. Por fim, realizo um descritivo de cada capítulo da série "Menina Mulher da Pele Preta" e em seguida, eu trago a conclusão deste trabalho. 
2. Roteiros de Menina Mulher da Pele Preta

2.1 Menina Mulher da Pele Preta - Episódio 1: Jennifer

Argumento e Roteiro

Renato Candido de Lima 
TELA PRETA

Professora fala aula de REDAÇÃo enquanto créditos sobem.

1 - INT/DIA - SALA DE COMPUTADORES/ESCOLA

Tela de computador mostra DOCUMENTO DE TEXTO escrito "Jennifer Ferreira Lopes da Silva" com tópicos escritos como "Formação", "Experiência Profissional", entre outros. PROFESSORA, em pé, arruma livros sobre a mesa.

\title{
PROFESSORA
}

Gente, faltam oito minutos pro

sinal! Quem quiser ver e-mails e tal, ok?

Mãos manipulam TECLADO DE COMPUTADOR E MOUSE. Jennifer, 17 anos, negra, pele clara, alta, cabelos onduladoencaracolados é quem manipula, ela está vestida com camiseta do uniforme escolar. Ao lado dela se aproxima Thamires, 17 anos, morena clara, cabelos lisos, vestida com camiseta do uniforme escolar cortado em diagonal que revela parte de seu bustiê, tem diversos penduricalhos no pescoço, pulso e orelhas. Thamires conecta seu celular na USB do computador e senta-se. Ao fundo há jovens manipulando computadores.

THAMIRES

Jennifer, rola mexer numas fotinhas?

Jennifer gesticula querendo dinheiro. Thamires lhe dá uma nota de $R \$ 2,00$ (ou $R \$ 5,00$ ). Jennifer pega e manipula mouse. Na tela do computador, minimiza-se documento de texto com currículo e maximiza-se foto de Thamires, de corpo inteiro vestida de bustiê rosa e minissaia preta. Jennifer insere linhas na imagem como se selecionasse a pele de Thamires, que olha atentamente para a tela e para Jennifer. Jennifer manipula e pele de Thamires na foto fica mais branca.

\author{
THAMIRES (off) \\ Ah, legal! \\ JENNIFER (off) (ri) \\ Legal... parece uma fantasma!
}

Jennifer olha tela e manipula mouse. Pele de Thamires fica mais escura. Thamires gesticula com as mãos em seus seios. Jennifer manipula o software e aumenta muito o tamanho dos seios de Thamires na foto. As duas riem. Jennifer diminui o tamanho dos seios de Thamires na foto 
e compara com a imagem anterior sem as modificações.

\author{
JENNIFER \\ E aí?
}

Thamires sorri e olha para seu corpo, em seguida, beija o rosto de Jennifer.

THAMIRES

Aproveita e posta as fotinhos pra mim?

\author{
JENNIFER \\ Qual a senha? \\ THAMIRES (sussurra) \\ Thamipervertida, tudo junto. Com H. \\ (tapa na bunda) Ái, ái, ô! (ri)
}

Jennifer e Thamires se olham, sorriem. Jennifer dá tapa na bunda de Thamires, que sai da sala.

Na tela de computador, campo de senha termina de ser preenchido e acessa PÁGINA ELETRÔNICA DE RELACIONAMENTO ORKUT. Jennifer manipula computador. No site com foto e nome de Thamires, há mensagens sedutoras de garotos e de rapazes, dentre estas, encontra a mensagem de Cauã, 16 anos, branco, alto, cabelos curtos, usa boné com a aba invertida. Ela clica numa pequena foto de cauã e vê algumas fotos do rapaz.

Jennifer olha para trás e para os lados, ela encontra os garotos que estão na sala e se atém a Cauã, vestido com uniforme escolar que agarra a definição de seus músculos e tem boné invertido como na foto do site. O rapaz olha para Jennifer; ela rapidamente disfarça, retorna a manipular o computador e nota que ao lado do monitor há uma FLOR DE PAPEL COLORIDO FEITA DE DOBRADURA. Jennifer a pega e olha para trás, ela encontra Cauã, que a olha. Jennifer vira sua cabeça para frente, contempla a dobradura e sorri. Em seguida, Jennifer se atém a tela do computador.

Algumas fotos de Thamires estão na tela do computador. Roupas curtas/coloridas e poses sensuais.

Jennifer olha para seu próprio busto, agarra sua camisa branca e a silhueta de seu busto aparece. Risadas ecoam, Jennifer se assusta ligeiramente e se aborrece. Ela se levanta, guarda a flor feita de dobradura colorida em seu estojo. Garotos 1 e 2, o primeiro moreno claro e o segundo 
negro, vestidos de uniforme com calça jeans, estão ao lado de Cauã e manipulam outro computador. Eles riem apontando para o monitor.

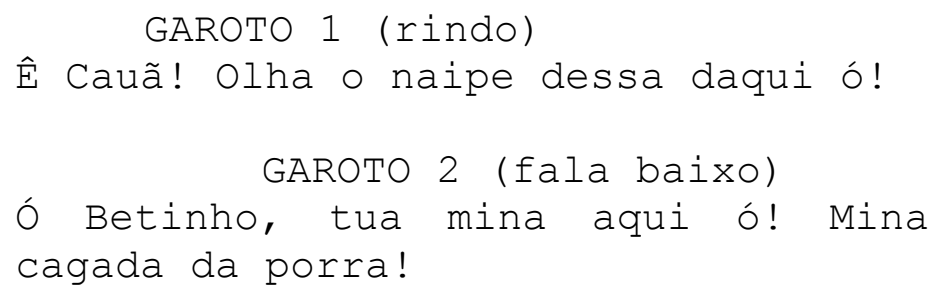

Betinho, 16 anos, negro, vestido com uniforme escolar, está próximo dos garotos, mas em outro computador. Ele olha o monitor e também sorri ligeiramente, em seguida ele olha para Jennifer, que sai de mochila.

2 - INT/DIA - CORREDOR DA ESCOLA

Jennifer sai correndo da porta da sala de aula e corre em direção ao banheiro. Entra som de torneira aberta.

3 - INT/DIA - BANHEIRO DA ESCOLA

Torneira derrama água. Mãos de Jennifer se enxáguam e lavam seu rosto, a garota se olha diante do espelho. Jennifer fecha a torneira e ajeita seu uniforme que não delineia o seu corpo. Jennifer fica cabisbaixa e suspira. Sinal escolar toca, começa som de burburinho de jovens.

4 - EXT/DIA - PATEO DA ESCOLA

Numa perspectiva subjetiva, Jovens e adolescentes conversam, gritam. Muitos caminham em direção a um portão preto.

Jennifer, séria e de mochila, caminha sozinha pelo pátio e sai pelo portão preto. Adolescentes saem pelo portão.

5 - EXT/DIA - RUA DA ESCOLA

Jennifer caminha pela rua. Ao fundo, com capacete de bicicleta na cabeça e mochila, Thamires pedala uma BICICLETA em direção a Jennifer e chega junto a Jennifer.

\section{THAMIRES}

Não me esperou?

JENNIFER

Pensei que ia pro Shopping... Você pedala? 
Thamires oferece outro capacete de bicicleta que está amarrado na parte traseira da bicicleta.

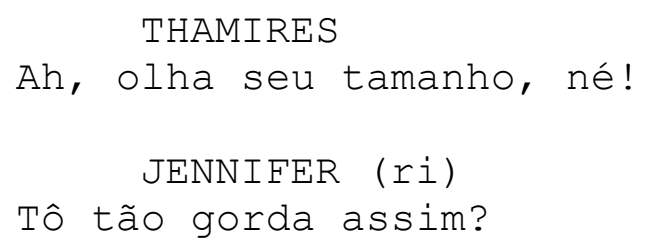

As duas sorriem e Jennifer se prepara para montar a Bicicleta junto a Thamires. CARRO REBAIXADO se aproxima.

$$
\begin{aligned}
& \text { JOÃo (off) } \\
& \text { Aê, Thammy! }
\end{aligned}
$$

Thamires desce da bicicleta e vai até João, 18 anos, moreno claro, cabelos espetados, óculos escuros tipo Spy que sai do carro junto a Baltazar, 19 anos, negro, vestido de moletom, que sai pela porta do passageiro no carro. Jennifer se mantém sobre a bicicleta.

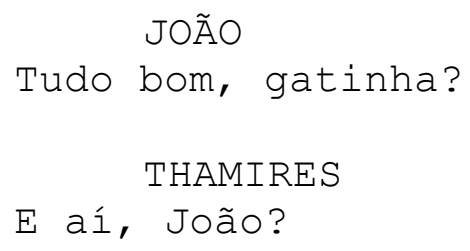

Thamires tira capacete e abraça João, que a abraça apalpando as nádegas dela. Thamires bate em João com o capacete; ele faz careta de repreensão, mas sorri.

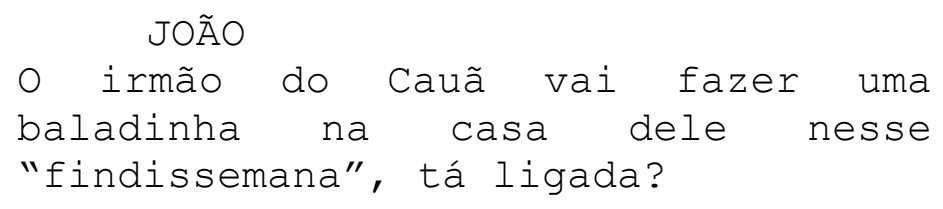


nem naquela baladinha lá da Melissa,

lembra? Eu e você... mó gostoso, né?

Abraçado a Thamires, João a aperta mais por entre os braços.

\author{
THAMIRES (ri) \\ Nossa! Mó bom!
}

Thamires beija João na Boca. Thamires está de costas para a amiga e ainda beijando João olha para Jennifer. Jennifer o olha reprovando-o. Termina beijo, João olha para Thamires.

\title{
JOÃO \\ Tua amiga da bicicleta vai?
}

Thamires demonstra dúvida. João olha para Baltazar.

JOÃO

$\hat{E}$ Baltazar! Convida a mina aê, ô!

Baltazar olha João e em seguida Jennifer.

BALTAZAR (seco)

Cê vai colar lá, mina?

Vou ver.

JENNIFER (séria)

BALTAZAR

Como cê se chama?

JENNIFER

Jennifer.

Jennifer olha para os três.

BALTAZAR

Vamo, Jão!

Baltazar olha para João. Thamires veste capacete, sobe na bicicleta, joga beijo para João. As garotas partem.

\author{
JOÃO \\ ...Te vejo lá, hein, Jéssica! \\ É Jênice! \\ BALTAZAR (fala baixo para João)
}


JOÃO (para Baltazar)

Tá mais pra Jarilene... (ri) Mó mina

estranha! Mas tem uns coxão, cê viu?

Baltazar ri. Thamires e Jennifer andam de bicicleta ao longe.

BALTAZAR (certo humor) (off)

Se liga, Jão! Num empurra essas

tranquera ái não, véi! A mina parece

aqueles macaco branco tipo da

África, que a gente viu na TV a

Cabo... Balbuíno, tá ligado?

6 - EXT/DIA - AVENIDA LARGA DO BAIRRO DE JENNIFER/THAMIRES

Imagens de casas vistas num ponto de vista em movimento.

JENNIFER (off)

Thamires, como que foi o lance entre você e o João? Foi você que chegou

junto? Ele que se declarou?

Jennifer e Thamires estão numa bicicleta no canto direito de uma grande avenida de periferia.

THAMIRES
Nada, ele chegou me agarrando na
balada. Deu um puta beijo gostoso e
trocamo telefone... e hoje a gente tá
junto aê...
JENNIFER
Então, mas e se você tomasse a
iniciativa?

EXT/DIA - RUA DE POUCO MOVIMENTO BAIRRO DE JENNIFER/THAMIRES

Imagens de casas e bares vistas num ponto de vista em movimento. Detalhe de pés de Jennifer pedalando.

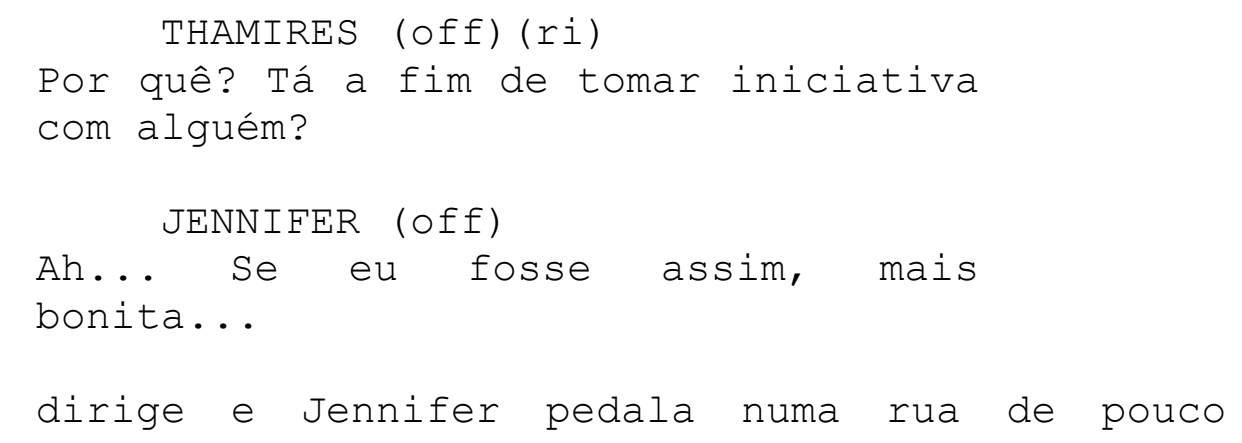


movimento.

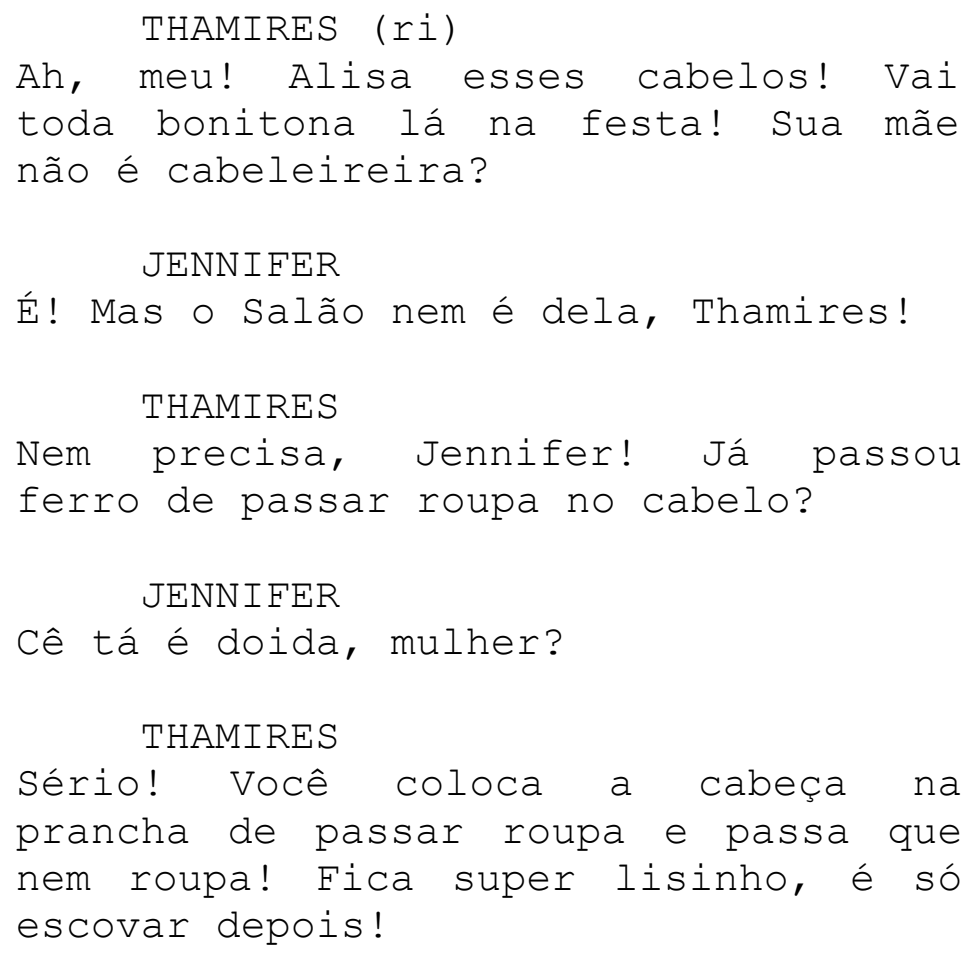

Jennifer e Thamires pedalam. Imagem pára em seu movimento.

7 - EXT/DIA - RUA DA CASA DE JENNIFER

Sobre a bicicleta, Jennifer e Thamires descem a rua. Param a bicicleta a frente da casa de Thamires. Jennifer desce, coloca capacete na traseira da bicicleta, que, em seguida e Thamires a leva.

Jennifer atravessa a rua, há uma KOMBI parada e ao lado da porta lateral do automóvel está Gusmão, 36 anos, negro, alto. Ele retira uma TORRE DE COMPUTADOR ao lado dele está Betinho, ainda com camiseta de uniforme escolar, que o ajuda carregando um MONITOR.

JENNIFER

Oi Betinho! (ri) Oi, seu Gusmão!

$$
\begin{gathered}
\text { GUSMÃO } \\
\text { Oi, Jennifer! }
\end{gathered}
$$

Jennifer abre o portão, mas não o fecha a pedido de Betinho. Gusmão e Betinho se aproximam com os equipamentos do computador.

BETINHO

Ô Jennifer! Espera aí. 


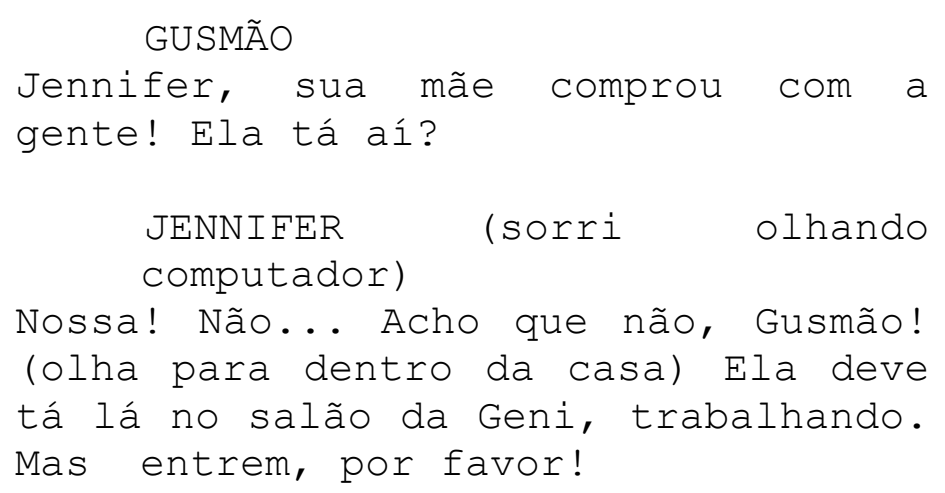

Betinho e Gusmão entram pelo portão, Jennifer o encosta. 8 - INT/DIA - SALA DA CASA DE JENNIFER

Gusmão e Betinho adentram a sala.

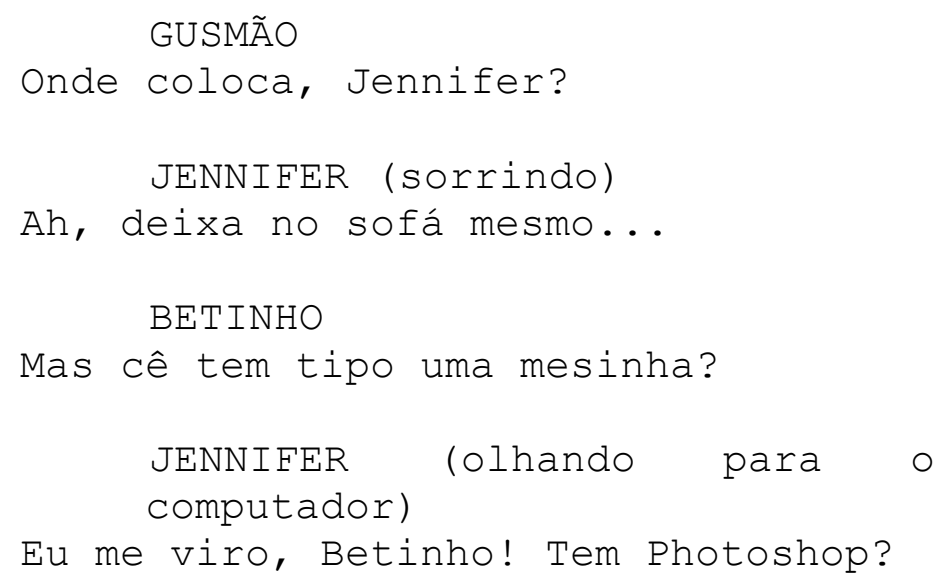

Betinho olha para Jennifer e ajeita sua pochete nas suas costas. Betinho acena para Jennifer estender as mãos. Betinho tem dificuldades de retirar algo da pochete. Som de telefone celular.

\section{BETINHO (para Jennifer)}

Peraí... Nada nessa mão, nada nessa outra, fecha os olhos!

Gusmão olha para Betinho e atende celular.

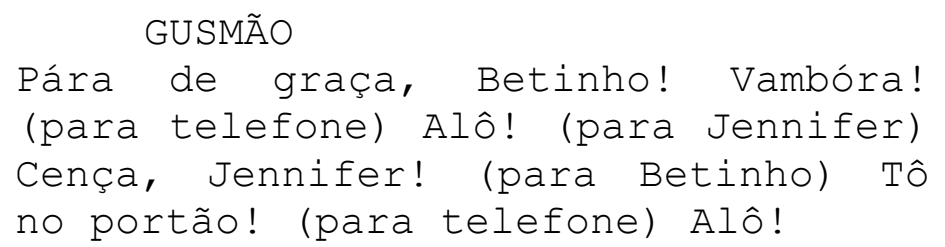


Jennifer acena positivamente com a cabeça para Gusmão e olha para Betinho, ela fecha os olhos. Gusmão sai da sala.

$$
\begin{aligned}
& \text { BETINHO } \\
& \text { Tó . . . Ái... }
\end{aligned}
$$

CD cai no chão, Jennifer abre seus olhos. Betinho pega a mídia caída e entrega a Jennifer.

\section{JENNIFER \\ Quanto é?}

Betinho gesticula para Jennifer ficar com o objeto. Jennifer beija o rosto de Betinho, que sorri levemente e se despede saindo pela porta.

Jennifer olha para o computador e sorri. Som de portão batendo. Jennifer pula de alegria e faz uma dança engraçada. Ela olha para trás e vê Betinho parado na porta, ela rapidamente pára de pular.

BETINHO

Esqueci! Veio esta câmera também!

Betinho entrega ESTOJO COM ARTE EM FLORES de câmera fotográfica a Jennifer. Betinho e Jennifer se olham.

$$
\begin{aligned}
& \text { BETINHO } \\
& \text { Er... Tchau, Jennifer. }
\end{aligned}
$$

Betinho sai, Jennifer abre o estojo da câmera e manipula o aparelho, distraidamente ela bate uma foto com flash, fato que a assusta ligeiramente.

9 - INT/DIA - QUARTO

Imagem de foto de Jennifer vinda da tela de computador. É uma foto torta e mal tirada. Outras fotos aparecem, são imagens de caretas de Jennifer. Jennifer, com uma toalha na cabeça, vestida de camisa grande e bermuda larga furtacor, está à frente do monitor. Ela ri, termina de comer num prato de comida e o coloca sobre o aparelho. Jennifer olha em direção a Janela e se levanta.

10 - EXT/DIA - LAJE DA CASA DE JENNIFER

Jennifer tira foto de uma montanha que tem um bairro à frente. Em seguida, Jennifer enquadra diversas pessoas do seu bairro e tira fotos. 
Num dado momento, Jennifer vê Thamires através da câmera. A amiga sai pelo portão e senta num pequeno muro de sua casa. Thamires está vestida de top com arte de flor estampada e bermuda agarrada. Jennifer tira fotos de Thamires, que está cabisbaixa. Em seguida, Jennifer tira fotos de partes do corpo de Thamires e olha para seu próprio corpo.

\section{1 - INT/DIA - QUARTO}

Imagens de tela de computador mostram fotos de Thamires.

No espelho, Jennifer dobra sua camisa, que agora parece um bustiê e abaixa a cintura de sua bermuda. Jennifer manipula sua câmera sobre o computador e aperta um botão. Ela corre para próximo da porta e realiza uma pose. Flash de Foto.

Imagens em "Still" seguidas, cada disparo de flash muda uma pose de Jennifer para a câmera. Som de porta sendo destrancada.

VERA (off)

\section{Filha?}

Jennifer desamarra rapidamente sua camisa e ajeita sua bermuda.

12 - INT/DIA - PORTA DO QUARTO

Vera, 40 anos, negra, magra, cabelos crespos, estatura mediana, abre a porta, ao fundo, Jennifer termina de abotoar a bermuda.

VERA

Filha, o Gusmão passou? (olha

computador) Ah! Que lindo!

JENNIFER

Bonito, né, mãe! ...Brigada!

Jennifer abraça Vera.

VERA

Olha veio tudo! Impressora! Veio com câmera também?

A mãe pega a câmera, mas Jennifer toma de sua mão sem sobressaltos. 
JENNIFER

Er... Tá sem pilha, mãe. Num coloquei o cartão de memória ainda.

Vera retira sua blusa e fica de camiseta.

VERA (cerra o rosto)

Hummm... O almoço tá quente ainda?

(olha relógio)

JENNIFER

Tá sim. Tá tudo quente. Só o bife tem que esquentar...

Vera sai do quarto.

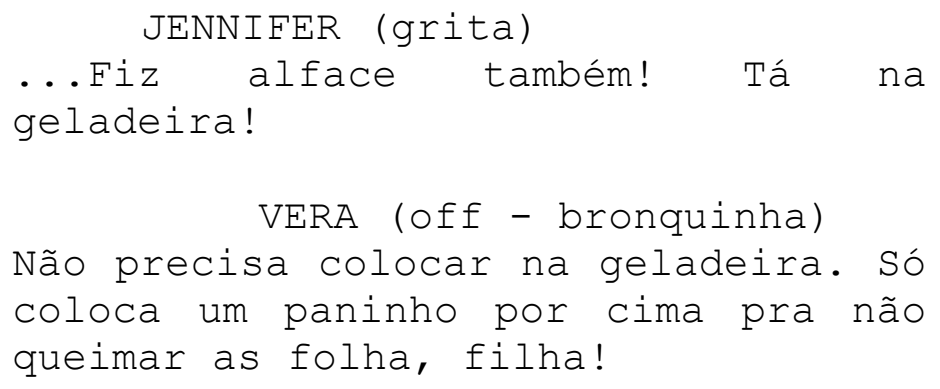

Em pé, Jennifer balança a cabeça negativamente e logo manipula o computador. A garota olha as fotos em que ela posou. Jennifer cerra o rosto e fecha o visualizador de imagens do computador. Jennifer se levanta da cadeira e sai. A dobradura da flor que Jennifer ganhou está sobre a mesa do computador. Som de programa televisivo qualquer (Sugestão: Chaves).

\section{3 - INT/DIA - SALA}

Vera, no sofá, almoça assistindo ao televisor. É um programa de comédia, Vera sorri. Jennifer, que está na porta do quarto contíguo à sala.

\section{JENNIFER}

Vou na Thamires!

\section{VERA!}

Tá!

Jennifer caminha até a porta da sala.

JENNIFER

Posso ir no salão mexer no meu cabelo? 
VERA

Tá corrido lá, filha! Inclusive

tenho que voltar daqui a pouco!

Vera não tira os olhos da TV. Jennifer olha os cabelos crespos da mãe e sua vestimenta. Jennifer está na porta da sala.

VERA (off)

A Claudinha pediu pra você fazer a mão de umas clientes dela na quinta

lá no salão.

JENNIFER

Tá bom...

Vera assiste ao televisor.

Mãe?

JENNIFER (off)

VERA (vendo TV)

Oi?

Jennifer olha para Vera.

JENNIFER

Nada...

Jennifer sai.

14 - EXT/DIA - RUA/PORTÃO CASA DE THAMIRES

Jennifer caminha e chega ao portão de Thamires, que está sentada no muro.

JENNIFER

Thamires! Sua mãe ainda vende roupa?

THAMIRES

Vende!

JENNIFER

ó! Vamos fazer assim? Ao invés de você me pagar em dinheiro o lance

das suas fotos, que tal ser paga com roupas.

THAMIRES

Humm... Mas que tipo? 


\author{
JENNIFER \\ Tipo as suas... assim!
}

Jennifer aponta para roupa que Thamires veste.

THAMIRES

Ah!... É uma boa, Jennifer! E aquela

dívida pode ser com roupa também?

JENNIFER

Opa! Fechou!

15 - INT/DIA - SALA DE COMPUTADORES/ESCOLA

Diversas fotos de Jennifer com várias mudas de roupa, sempre bem agarradas e apertadas, são passadas num monitor de computador. O Brilho da tela ilumina os rostos de Jennifer e Thamires, as duas estão de camiseta branca.

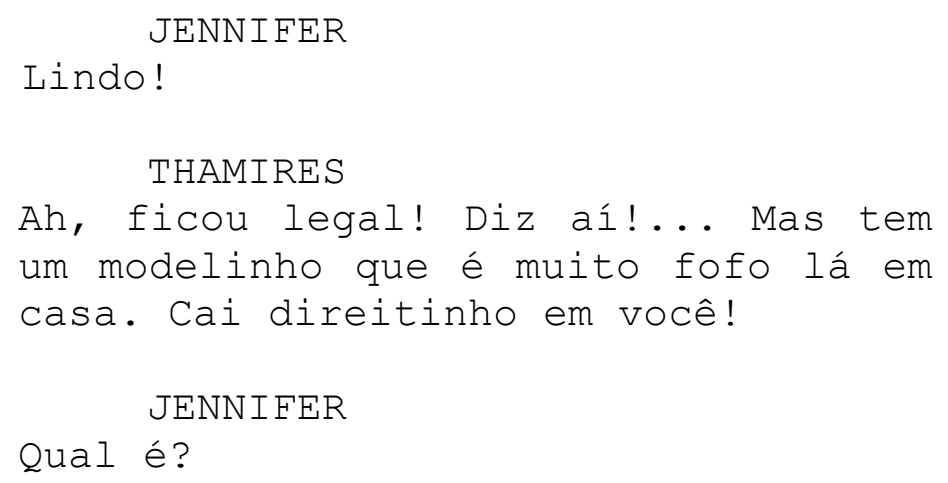

Mãos de Jennifer manipulam agilmente o teclado. Entra imagem de tela de computador com site de fotolog e foto de Thamires. Diversas fotos de Thamires são apresentadas na tela.

\title{
THAMIRES (off)
}

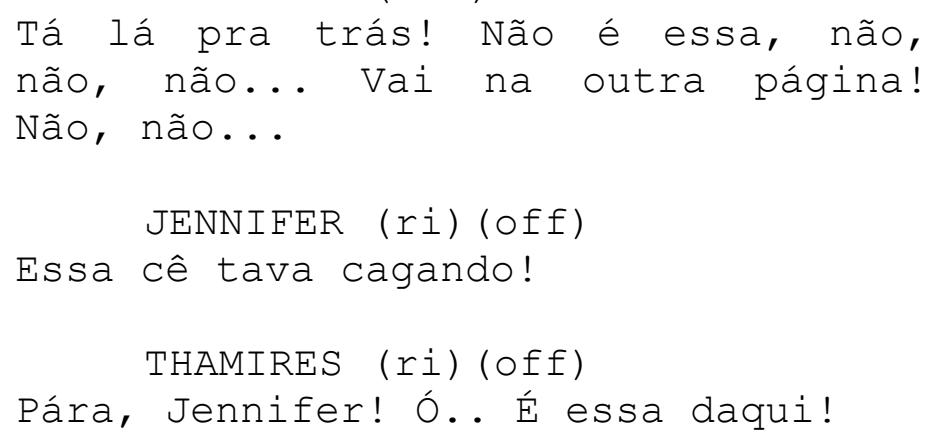

Pára numa foto em que Thamires veste mini-saia e bustiê vermelhos. Jennifer olha para Thamires, que por sua vez 
atém-se a tela do computador.

THAMIRES

Da hora, né!

Silêncio. As duas se olham. Cauã passa por trás de Jennifer e Thamires, ele abraça Thamires por trás.

CAŨ̃

Olha que gatona gostosa! Deixo ver

mais? Passa aí, Jennifer!

Jennifer olha para o casal, que se atêm à tela do computador. Outras fotos passam na tela. Pára numa foto que Thamires está ao lado de uma garota negra de cabelo liso.

CAUÃ (off)

Quem é a morenona?

THAMIRES (off)

Minha prima Kailine, de Uberaba. Bonita?

Jennifer olha para o casal, está séria.

$$
\text { CAŨ̃ (off) }
$$

É! Ela deu um jeito nos cabelos, né! Mas entre vocês duas, prum lance sério assim, eu sou mais você, ó! (tentativa de xaveco) Inclusive, eu quero que você vá com esta roupa lá na baladinha da minha casa!

THAMIRES (off)

Se liga, Cauã! Eu tô com o João!

Cauã e Thamires conversam.

CAUÃ

Orra, mina! Você vai me abandonar assim? Tô mó carente!

\section{THAMIRES}

Ô, qui dó!

Thamires dá beijo no rosto de Cauã. Jennifer os vê. Cauã dá tapinha nas costas de Jennifer e sai. Jennifer olha Cauã se afastar.

16 - INT/DIA - QUARTO 
Jennifer, de camisa larga e bermudão, manipula uma foto sua em que ela está vestida de bermuda e blusa agarradas. Ela aumenta o tamanho de seus seios, mas cerra o rosto. Na tela do computador está O Aviso: "Tem certeza que quer apagar o arquivo", ponteiro do mouse clica no "Sim".

A frente de uma camiseira, Jennifer abre a gaveta e pega diversas roupas como mini-saias, bermudas pequenas e blusinhas. Com uma muda de roupa, Jennifer encara-se no espelho e apalpa seus seios, aumentando o seu decote.

Com diversas outras mudas de roupas, Jennifer realiza diferentes poses. Quase todas elas são poses sensuais.

\section{7 - INT/DIA - SALA DE COMPUTADOR/ESCOLA}

Fotos sensuais de Jennifer são vistas uma a uma numa tela de computador. Em algumas fotos, Jennifer tem seus cabelos trocados para um tipo loiro liso. Cauã manipula mouse e teclado. Ao fundo, professora escreve algo na lousa, ao lado e um pouco a frente Cauã, Jennifer e Thamires manipulam seu respectivo computador. Tela abre página de Recados do site "Orkut", lá está uma mensagem de Jennifer escrito: "Tá carente mesmo? Eu te cuido", há um emoticon ";)" e também ":-\{\}". Cauã ri e olha ao lado.

CAUÃ (fala baixo)

Ê mano, chega aí!

Imagens de fotos de Jennifer. Dois garotos estão ao lado de Cauã. Imagens de outras fotos de Jennifer.

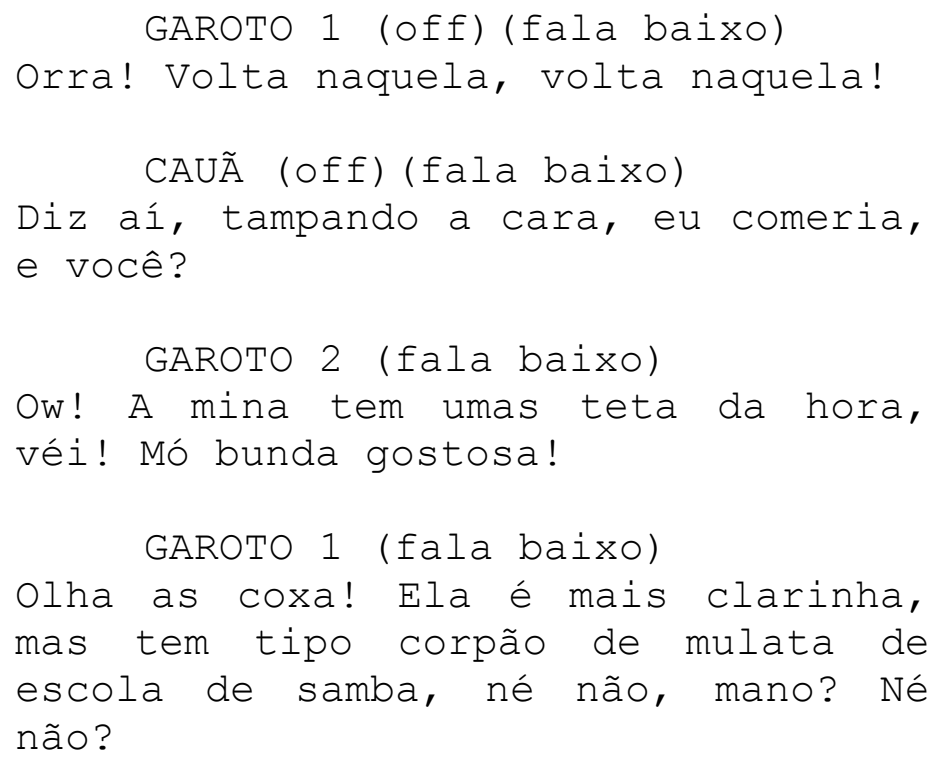


CAŨ̃

É bem do tipo Raimunda, véi!

Garotos riem. Jennifer manipula seu computador e olha para trás ao som das risadas. Som de batidas na lousa branca. Professora, em pé, olha para Cauã.

PROFESSORA

Cauã! Vocês também!

Garotos voltam aos seus lugares. Cauã e Jennifer se olham. Jennifer volta a manipular o computador e sorri. Ela digita seu curriculum vitae num editor de textos. Entra som de programa radiofônico com a música "Testando" de Ellen Oléria.

18 - INT/DIA - SALÃO DE BELEZA

Música continua como fundo sonoro. Mão de Jennifer pinta de esmalte claro unhas de mão feminina negra. Jennifer é quem as pinta.

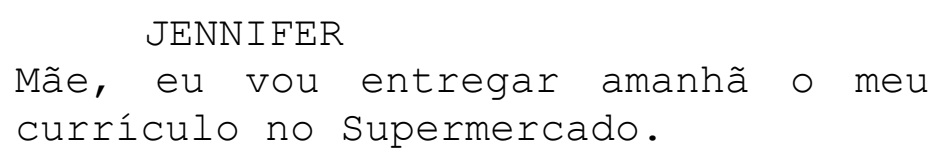

Vera passa creme nos cabelos de Denise, morena, cabelos pouco encaracolados. Ao fundo, refletida num espelho, Jennifer olha para Vera e segura mãos de Clarice, negra, cabelos encaracolados.

VERA

Pra qual vaga, filha?

JENNIFER

Operadora de Caixa...

VERA

É... interessante!

JENNIFER

Eu queria entregar o meu currículo toda bonita, sabe? Alisar meus cabelos!

Clarice olha Jennifer. A garota faz flores na unha de Clarice.

\section{CLARICE}

Poxa, Jennifer. Você já é tão bonita... Pra que alisar? 


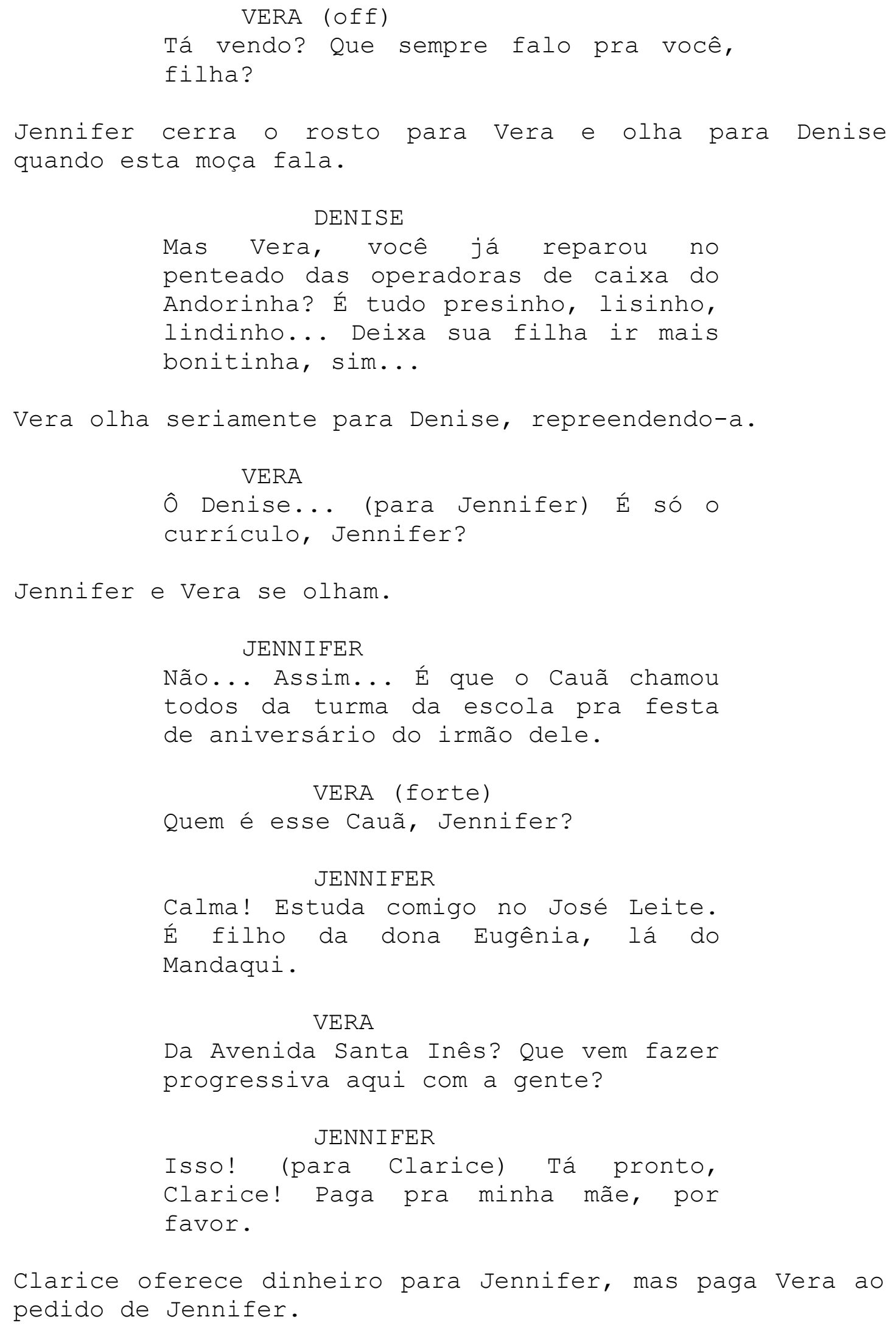

Clarice oferece dinheiro para Jennifer, mas paga Vera ao pedido de Jennifer.

VERA

Pessoalzinho bem de vida, esses. A Eugênia vai estar lá nesse 


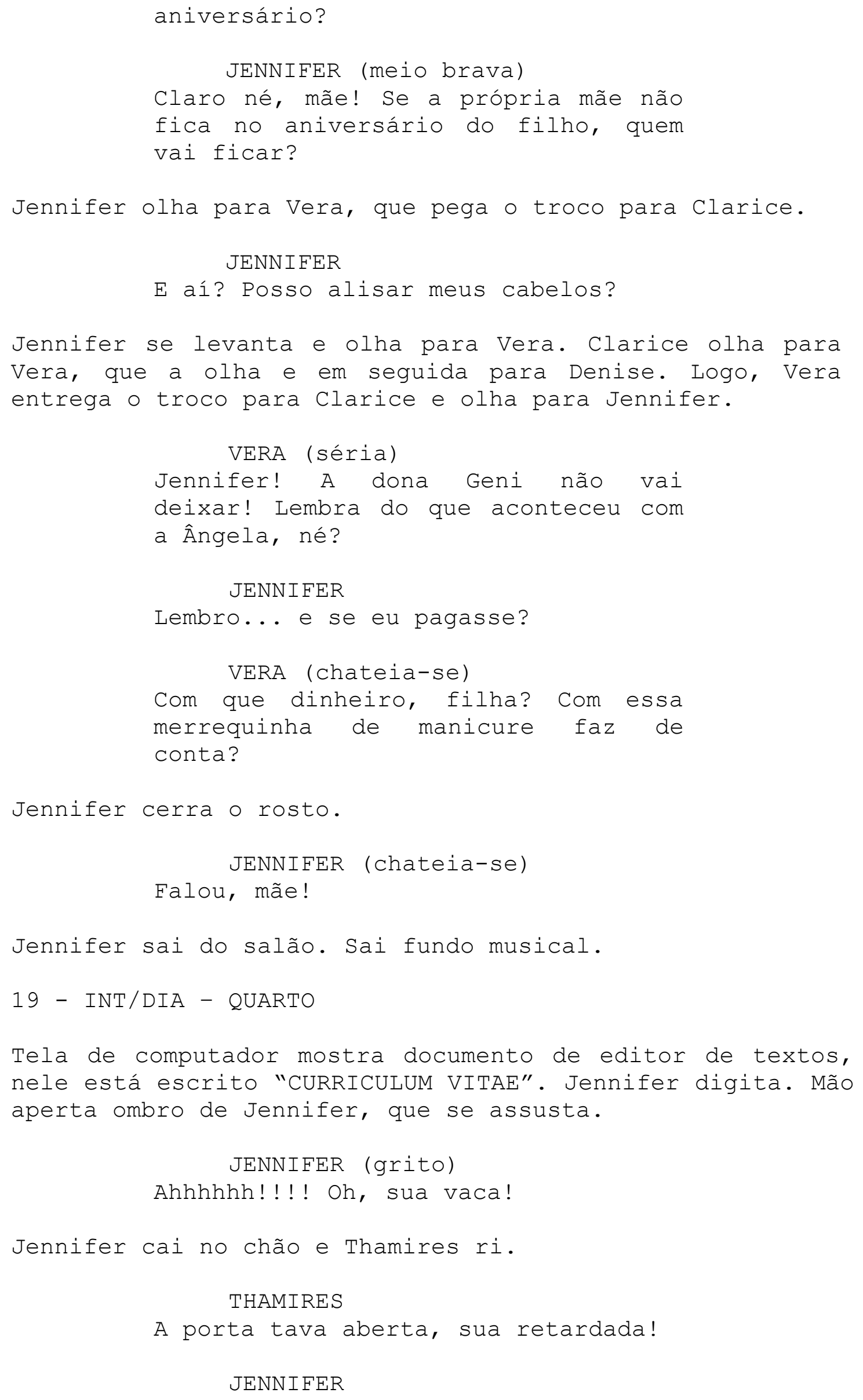


Pô, num faz isso! Vai se foder! (pra

si) Puta que pariu!

Jennifer se levanta e coloca a mão na altura de seu coração. Thamires começa a rir descontroladamente e deita de bruços sobre a cama de Jennifer. Jennifer, em pé, começa a rir também e dá um tapa na bunda de Thamires.

\section{THAMIRES (rindo) \\ Ai ai, ô!}

Thamires senta na cama.

THAMIRES

Você vai na festa do irmão do Cauã?

Ao fundo, Jennifer mexe numa gaveta da camiseira e retira algumas roupas.

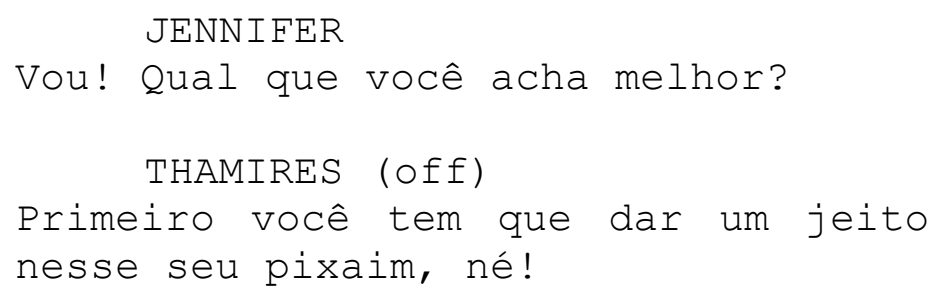

Entrecortes. Thamires olha Jennifer se despir. Detalhes do pôster no armário de Jennifer. Detalhe de tela de computador no qual há foto manipulada de Jennifer em que a garota está de cabelos loiros/lisos e sua pele mais clara. Detalhe da flor feita em dobradura. Thamires olha atentamente Jennifer.

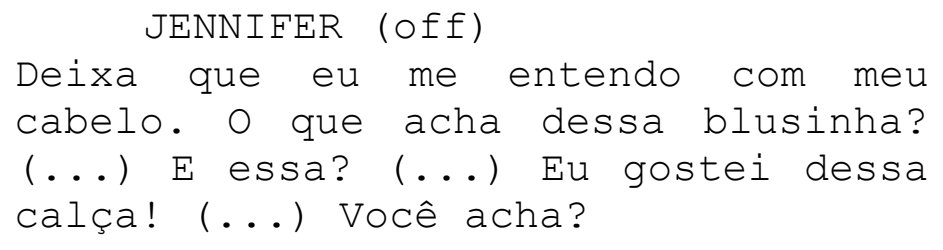

Detalhes do corpo de Jennifer ao estar vestida com diversas roupas. Seios, barriga, sorriso, pés no chão e Jennifer veste uma bermuda agarrada. Decote de Jennifer com uma blusa agarrada.

$$
\text { THAMIRES (off) }
$$

Eu prefiro a vermelha (...) Essa de florzinha é boa! (...) Oh, Jennifer, seus peitos são mó bonitos (olha seios)... por que não valoriza eles?

Thamires olha atentamente Jennifer. 


\section{E essa?}

JENNIFER (off)

\section{THAMIRES}

Parece sua mãe!

Jennifer está vestida de calça e camisa social feminina. Ela sobe num salto e olha-se no espelho.

\section{JENNIFER}

E é dela! Hehe, ficou ótima!

20 - INT/DIA - SALA DE AULA

Pés com sapato de salto baixo caminham e param ao lado de uma carteira. Jennifer assenta-se em sua carteira escolar. Thamires chega e a beija longamente no rosto. Jennifer sorri. Thamires senta na carteira atrás de Jennifer e olha para amiga.

Jennifer levanta seu rosto e olha para Cauã que está sentado ao fundo. O rapaz olha para Jennifer, ela sorri. Jennifer olha para baixo e em seguida levanta seu rosto, ela vê Thamires que a olha e vê que Cauã também a olha. Professora olha para Jennifer.

\section{PROFESSORA}

Algum problema, Jennifer?

Jennifer olha para Professora e sorri constrangida.

21 - INT/DIA - BANHEIRO DA ESCOLA

A frente do espelho, Jennifer, com uniforme escolar, passa a mão em seus cabelos. Jennifer os prende e se olha, em seguida ela os solta e balança sua cabeça. Ela pega sua mochila e retira uma muda de roupa social. Num reflexo do espelho, Jennifer ajeita sua roupa social. Jennifer se encara e suspira, Thamires entra no banheiro e Jennifer levanta seu rosto.

\section{JENNIFER \\ Você me ajuda, Thamires?}

22 - INT/DIA - SHOPPING/ENTRADA DE SUPERMERCADO.

De mochila nas costas, Jennifer e Thamires caminham lado a lado. Seguidas vezes, Thamires olha para Jennifer, que não a vê. 


\begin{abstract}
INT/DIA - SUPERMERCADO
Jennifer olha para as balconistas e em seguida para Thamires de baixo para cima. Thamires está vestida de uniforme escolar bastante agarrado em seu corpo.

Jennifer e Thamires dobram uma curva feita pela sequencia de caixas do supermercado. Ao final da curva, Jennifer olha para frente e vê Homem, 40 anos, negro, camisa de manga curta e gravata, uniformizado, que anota algo numa prancheta de mão. Abaixo da prancheta há com alguns envelopes. Olhando para o homem, Jennifer rapidamente dá meia volta e retorna para a curva feita pela sequencia de caixas do supermercado, lugar onde ela e Thamires não podem ser vistas pelo Homem.
\end{abstract}

\title{
THAMIRES \\ Que foi?
}

Jennifer retira envelope laranja da mala.

JENNIFER

Fica com a minha mala! Me espera na Praça de Alimentação! No Mac Donalds!

THAMIRES

Peraí! Vou lá contigo!

JENNIFER

Não! Vou sozinha!

Thamires e Jennifer se olham. Jennifer sai e caminha pelo corredor formado pelos caixas, ela se aproxima do homem uniformizado.

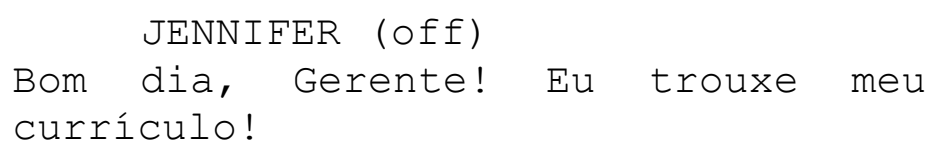

Homem uniformizado pega envelope laranja de Jennifer e o coloca junto aos outros envelopes que segura junto a prancheta. Homem anota algo na prancheta, Jennifer o olha.

HOMEM

(para alguém) Regiane, pega os
currículos e leva lá em cima pra
mim?

Homem pára de escrever e olha Jennifer. 


\author{
Algo mais? \\ JENNIFER \\ Não vai ler meu currículo?
}

HOMEM (olha Jennifer)

Homem sorri.

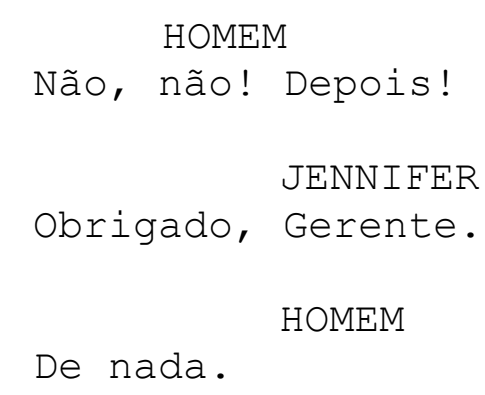

Jennifer cerra o rosto, dá meia volta e caminha rapidamente a passos largos.

23 - INT/DIA - TUNEL DE PASSAGEM SUPERMERCADO/SHOPPING

Jennifer caminha pelo túnel e olha para algo.

INT/DIA - SHOPPING

Subjetiva. Jennifer olha para fachadas de lojas, se atém a figuras loiras em cartazes e funcionárias de shopping.

$$
\begin{aligned}
& \text { THAMIRES (off) } \\
& \text { Jennifer! Ô, Jennifer! }
\end{aligned}
$$

24 - INT/DIA - PRAÇA DE ALIMENTAÇÃO

Subjetiva. Fachada desfocada de Loja do Mcdonalds. Imagem desce, Thamires, entrando em foco, olha para Jennifer.

THAMIRES

E aí? Deu certo?

Jennifer olha Thamires.

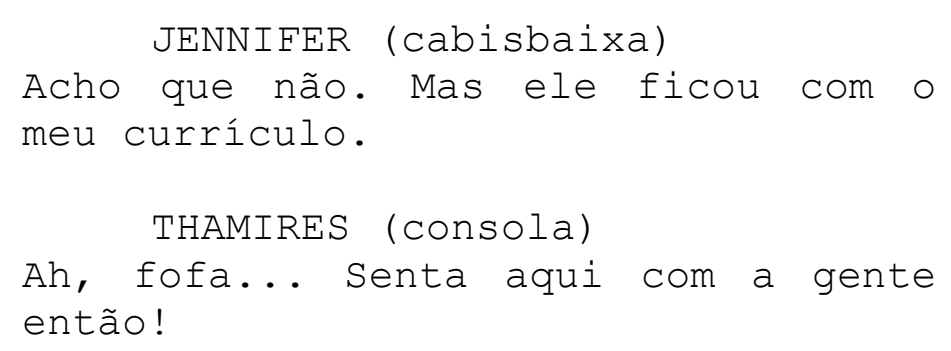


Jennifer olha a frente e vê Cauã sentado a uma mesa da lanchonete. O rapaz olha para Jennifer, que sorri, ao lado estão Garotos 1 e 2. Thamires olha para Jennifer. Cauã bebe sundae num grande copo.

\title{
CAŨ̃ \\ Quer, Jennifer?
}

Jennifer, já assentada, aceita balançando a cabeça e bebe do sundae. Cada um dos colegas de escola olham Jennifer. Mão cutuca ombro de Jennifer, um rapaz uniformizado do supermercado com CAMISA AMARELA lhe entrega uma FLOR DOBRADA COM PAPÉIS COLORIDOS. Jennifer estranha.

RAPAZ

Mandaram lhe entregar.

De quem é?

JENNIFER (pega flor)

Rapaz sai. Cauã, Jennifer, Thamires e garotos olham entre si e explodem em gargalhadas. Jennifer sorrindo, mas não entende.

25 - INT/NOITE - QUARTO

Sob o brilho de tela do computador e a luz de um abajur (ou mesmo de uma luz de poste ou da Lua que entra pela janela), Jennifer tem dobradura de flor nas mãos. Ela a olha e guarda junto a um pequeno baú de mão com bijuterias. Som de porta se abrindo e entra claridade de luz oriunda de outro ambiente.

\section{VERA (off) \\ Jennifer...}

Jennifer manipula sua foto em que ela mudou seus cabelos para loiro/lisos, sua pele está branca e seus olhos estão azuis. Vera se aproxima e senta na cama da filha.

VERA

Filha?

Jennifer, cabisbaixa e sentada ao computador, vira-se para Vera.

\author{
JENNIFER (cabisbaixa) \\ Oi Mãe. Como foi no trabalho?...
}

Vera olha para imagem manipulada de Jennifer no computador. 


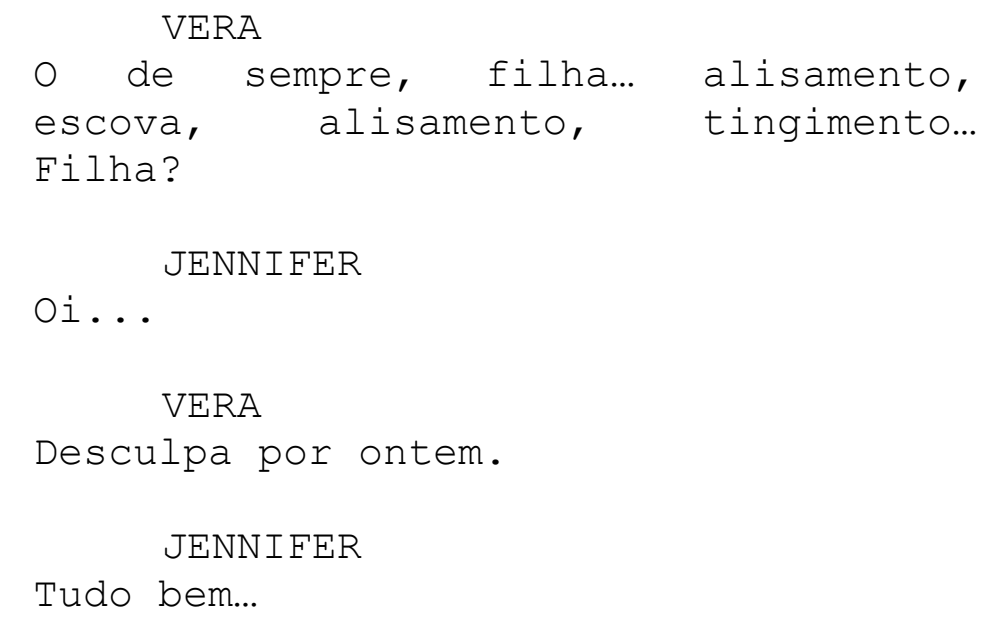

Vera coloca sua bolsa sobre mancebo.

VERA

Jennifer...

Vera bate palma da mão na cama, convidando a filha para se sentar ao lado dela. Elas se olham e Jennifer se levanta da cadeira e se assenta na cama.

VERA

Uma vez, a minha avó, sua bisavó, me ensinou a ser bonita...

Vera se levanta, pega cachos do cabelo de Jennifer e os trança. Entra som de pássaros cantando e programa radiofônico que toca música "Olhos Coloridos" de Sandra de Sá.

\section{6 - EXT/DIA - LAJE DA CASA DE JENNIFER}

Jennifer, com pano na cabeça que cobre parcialmente seus cabelos (trançados?), vestindo bermuda clara e camisa branca agarrada, estende roupas no varal. Jennifer olha para a rua e vê João e Baltazar sentados trocando palavras ríspidas com Thamires, que veste bermuda agarrada e bustiê. Jennifer diminui volume do rádio. Thamires parece discutir com João.

EXT/DIA - RUA DA CASA DE JENNIFER

Jennifer abre portão de sua casa e caminha pela rua, indo até portão da casa de Thamires.

$$
\begin{aligned}
& \text { BALtAZAR (off) } \\
& \text { E aí, gatinha? }
\end{aligned}
$$


EXT/DIA - PORTÃO DA CASA DE THAMIRES

Jennifer chega. Thamires, cabisbaixa, a olha.

BALTAZAR

Tá no jeito, hein?

JENNIFER

Jeito de quê?

BALTAZAR

Jeito... Jeitão...

Baltazar leva suas mãos ao seu peito e sorri.

Se liga!

JENNIFER

BALTAZAR (corta)

Calma! A gente vai levar vocês lá na baladinha do Cauã .

Thamires olha para Baltazar.

JENNIFER

Vem cá, te pedi carona?

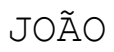

Não não, mas é tipo cortesia...

JENNIFER

Cortesia o cacete, seus folgado!

Vocês só querem carne nova no pedaço pra foder e jogar fora!

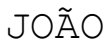

Relaxa Mina, a parada é o seguinte...

JENNIFER (corta)

A parada é que a gente não vai com vocês! Dá pra entender, ou vou ter que desenhar?

Thamires chora. Jennifer e João se encaram. Jennifer encara Baltazar.

BALTAZAR

Macumbeira do caralho!

João e Baltazar entram no carro e saem. Thamires e 
Jennifer encaram os rapazes.

Ao longe, o carro vira numa rua lateral. Jennifer não se contem e solta uma risada, em seguida, Thamires limpa choro e ri. Jennifer beija cabeça de Thamires.

Betinho, uniformizado como funcionário do supermercado (calça amarela com logotipo da empresa e calça azul), passa pela rua e cumprimenta as duas. Elas o cumprimentam e riem uma para a outra.

\section{JENNIFER \\ $\hat{E}$ Betinho!... Chega â̂!}

Um tanto distante, Betinho para e se vira. Ele se aproxima de Thamires e Jennifer.

\section{BETINHO}

Aê Thamires! Beleza, Jennifer?

Jennifer o cumprimenta.

JENNIFER

Belê! Você vai na baladinha do Cauã amanhã?

Betinho olha para Jennifer, em seguida os dois se olham. Sobe música funk.

\section{7 - INT/NOITE - EESTA}

Betinho bebe refrigerante num copo plástico e dança sozinho. Garotos e garotas dançam funk. Jennifer adentra o recinto ao lado de Thamires. Jennifer está vestida com visual de festa black. Ela está maquiada e seus cabelos estão trançados e soltos (ou cabelo estilo Vanessa da Mata). Thamires usa mini-saia jeans e miniblusa. Ela também está maquiada, utiliza muitas bijuterias e seus cabelos estão alisados.

Alguns rapazes as olham, inclusive João que sorri. Thamires vê João e sorri, eles se olham. João pisca olho. Thamires se aproxima de João, sob o olhar sério de Jennifer, Thamires e João se abraçam e se beijam.

Jennifer vai até o DJ da festa e fala algo no ouvido do rapaz e entrega um tocador de Mp3. Em seguida, o DJ acena positivamente. Sai música que estava tocando (funk) e entra música "Olhos Coloridos" de Sandra de Sá. Jennifer começa a dançar a musica black-soul sozinha, em seguida, Betinho se aproxima e dança junto a Jennifer. Jennifer 
olha em volta e vê, num canto, Thamires e João se beijando.

Ao longe, Jennifer vê Baltazar, que a olha. Jennifer olha para outro lado e encontra Cauã. Eles sorriem, Jennifer sorri e caminha em direção a cauã de braços abertos, abandonando Betinho. DJ coloca outra música (eletrônica ou funk).

Quando Jennifer e Cauã se encontram, a garota tenta beijálo, Cauã vira Jennifer de costas e a abraça por trás beijando e sussurrando na orelha da moça. Jennifer sorri de olhos fechados. Cauã leva a garota para outro ambiente.

Cauã e Jennifer se beijam efusivamente apalpando-a, em seguida, o rapaz sussurra algo a Jennifer e aponta para alguns garotos atrás de Jennifer, são os garotos 1 e 2 da escola. Eles a olham de cima a baixo, um deles coça seu púbis. Jennifer olha para os garotos e para Cauã, que mantém seu sorriso e seus olhos entre-abertos, como se estivesse embriagado. Jennifer agarra Cauã pelo colarinho e discute com o rapaz esfregando-o na parede, o som da música impede saber o que eles falam. Jennifer ameaça dar um soco, Cauã se protege, mas a garota dá um tapa no rosto do rapaz como se o acordasse e o ameaça gesticulando com a mão .

Jennifer olha em volta e vê João beijando e dançando com outra garota. Em seguida, sai vai para outro ambiente e encontra Thamires encostada na parede. Ela está chorando e bebendo cerveja num copo plástico. Jennifer chega ao lado de Thamires, a amiga tem movimentos lentos e vacilantes tanto que deixa cair o copo plástico no chão.

Jennifer olha para um corredor da casa e vê Cauã beijando outra moça. Jennifer desvia seu olhar para um pufe do local e encontra Betinho que realiza dobradura num papelguardanapo. Betinho desvia seu olhar da dobradura para Jennifer, que o olha, mas em seguida consola Thamires. A amiga de Jennifer, chorando, abraça-a rápida e fortemente. Thamires chora, levanta seu rosto. Thamires dá um selinho em Jennifer. As duas amigas estão de olhos fechados até que, rapidamente, Jennifer abre seus olhos, as duas amigas se olham e saem uma apoiada na outra.

28 - INT/DIA - SALA DE COMPUTADORES/ESCOLA

A sala de aula está em silêncio. Jennifer olha seu perfil em site de relacionamento pessoal, ela apaga álbum de fotos em que ela posa com roupas provocantes. Ela apaga 
várias mensagens enviadas para ela em que se evoca lesbianismo entre Jennifer e Thamires.

Jennifer olha em volta, Thamires, de óculos escuros, está noutro computador. Jennifer minimiza o browser e vê outra página aberta, trata-se de um e-mail. Ela abre a Mensagem intitulada "Aprovada". No corpo da mensagem relata-se sobre a aprovação de Jennifer para uma entrevista de emprego.

29 - INT/NOITE - QUARTO DA CASA DE JENNIFER

Jennifer, de bermudão e camisa branca larga, dobra roupas como pequenas bermudas, mini-blusas, mini-saias e as guarda num saco plástico. Ela se levanta, olha-se no espelho.

30 - EXT/DIA MANHÃ - PORTÃO/RUA DA CASA DE JENNIFER

Jennifer sai pelo portão de sua casa. Thamires, vestida de uniforme escolar, retira sua bicicleta do portão e a ajeita. Thamires estranha.

THAMIRES

Não vai pra escola?

JENNIFER

Não. Tenho entrevista de emprego.

As duas começam a caminhar. Sobem uma ladeira. Bicicleta faz som de catracagem.

THAMIRES

No supermercado?

JENNIFER

No supermercado...

Thamires coloca capacete de bicicleta.

THAMIRES

E se passar? Como ce vai fazer, Jennifer?

JENNIFER

Ah... Se eu passar, vou trabalhar de manhã e de tarde.

THAMIRES

Vai sair da escola! 


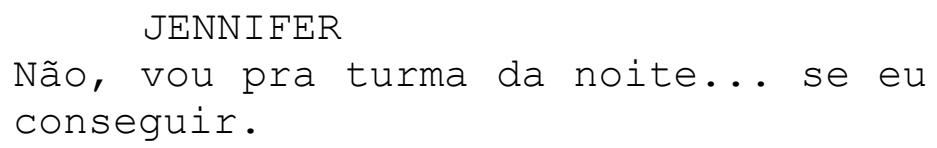

Silêncio.

THAMIRES

Jennifer... Quer uma carona?

Jennifer e Thamires se olham. Jennifer pega capacete sobressalente na traseira da bicicleta de Thamires e senta no selim. Jennifer pedala e Thamires dirige o guidão.

31 - EXT/DIA - RUAS E AVENIDAS DO BAIRRO

Movimento. Na bicicleta, Jennifer e Thamires caminham por paisagens do bairro. Elas passam pela mesma avenida larga em que passaram anteriormente.

Movimento. Jennifer e Thamires pedalam por um mirante em que a cidade se vê ao fundo.

Tableau. Na frente de um boteco, Jennifer e Thamires passam de bicicleta, clientes do bar acenam para o espectador.

Tableau. Jennifer e Thamires pedalam numa avenida de leve aclive com vista para outros morros onde há um ponto de ônibus, Pessoas num ponto de ônibus acenam para ônibus que chega.

Movimento. Jennifer e Thamires pedalam por uma leve descida onde há um conjunto habitacional popular e uma montanha florestal ao fundo.

Tableau. Ônibus lotado passa por uma ladeira.

Tableau. Jennifer e Thamires pedalam por uma favela ao lado de uma rua plana.

Movimento. Jennifer e Thamires pedalam por uma rua muito larga em que ao fundo, ao longe, há uma montanha florestal.

Tableau de Mulher Negra 1, 40 anos, numa biblioteca.

Tableau de Mulher Negra 2, 80 anos, a frente de sua casa.

Tableau de Mulher Morena 1, 22 anos, a frente de um muro grafitado. Ela tem marcas de tintas na roupa. 
Tableau de Mulher Negra 3, 35 anos, num salão de Beleza.

Tableau de Mulher Branca 1, nordestina, 26 anos, sentada ao volante de um ônibus de linha.

Tableau de Mulher Negra 4, 33 anos, de jaleco branco, numa sala de Fisioterapia.

Tableau de Mulher Negra 5, 65 anos, a frente de pinturas e quadros.

JENNIFER (over)
Sou Jennifer. Jennifer Ferreira
Lopes da Silva. Nasci aqui na Vila
Nova Cachoeirinha. Passei minha
infância na Bahia e com oito anos eu
voltei pra cá com minha mãe... Tenho
dezessete, vou fazer dezoito mês que
vem... Estudar? Vou fazer faculdade
de Computação ou de Design
Gráfico... Gosto, gosto bastante...
Experiência? Olha, com dezessete
seria injusto dizer que sou
experiente, mas tenho uma imensa
vontade de aprender neste trabalho,
aprender todas as fases e fazer de
coração... Conheço o Word, Excel,
Powerpoint... Ah, eu gosto do
Photoshop, do Corel, esses de
desenhos, sabe?... Pretendo ajudar
em casa, ajudar minha mãe a pagar as
prestações da casa onde a gente
mora, pagar o nosso computador,
pagar uma faculdade futuramente ou
até estudar numa Universidade
Pública... construir minha vida...
Ser sincera com que eu sei fazer e
com minha capacidade de aprender...
Ser sincera com minhas ancestrais,
mulheres que lutaram de alguma
forma pela liberdade... e que hoje
me dão a certeza para me sentir
forte e ser o que sou; resistindo,
lutando e me afirmando.

Som de equipamento que supermercado.

32 - INT/DIA - SUPERMERCADO

Operadoras de Caixa trabalham. Jennifer é uma delas e 
passa diversos produtos sobre leitor óptico e atende diversos clientes em seguida. Numa pausa, ela olha para as outras operadoras, todas estão de cabelos presos. Betinho passa carregando carrinhos de compras vazios.

HOMEM

Jennifer, os cabelos!

Homem gerente passa ao lado do caixa onde Jennifer trabalha. Jennifer amarra seus cabelos trançados e passa mais produtos pelo leitor óptico.

Grupos de adolescentes vestidos de uniformes escolares passam pelo corredor do supermercado. Eles brincam entre si, riem, tomam sorvete entre si, uma garota beija um garoto. Jennifer os olha.

\author{
CLIENTE (off) \\ ô, balconista! Você é retardada?
}

Vários objetos estão sobre a esteira automática do caixa. Jennifer os passa mais rapidamente pelo leitor óptico. Jennifer fala apontando para a cara de Cliente.

JENNIFER (brava)

Não! Não sou retardada! E mesmo que

fosse, o senhor não teria o direito

de me destratar dessa maneira!

Compreendeu bem?

Cliente e Jennifer se encaram.

Que bom.

JENNIFER (indignada)

Jennifer passa o último produto. Cliente paga, Jennifer lhe dá troco. Cliente sai. Jennifer limpa a esteira e ameaça chorar de raiva, mas limpa seus olhos. Sobre medidor de peso de alimentos na esteira, joga-se uma flor feita de dobradura de papel colorido.

\author{
BETINHO (off) \\ Nada nessa mão, nada nessa...
}

Jennifer desvia seu olhar para Betinho, em seguida ela sorri e desconcerta-se. Betinho oferece uma flor vermelha com o caule imerso num vidro com água a Jennifer. Jennifer ri, com lágrimas nos olhos. Ela pega, passa as mãos sobre a flor e guarda o vaso por dentro do balcão. Jennifer enxuga seus olhos e gesticula para Betinho como se fosse 
segredar algo ao ouvido, mas a garota rouba um beijo rápido e o empurra novamente. Jennifer olha para os lados e sorri para Betinho.

CRÉDITOS FINAIS 
2.2 Menina Mulher da Pele Preta - Episódio 2: Larissa S/A

\author{
Argumento \\ Carlos Alexandre Pereira \\ Renato Candido de Lima
}

Roteiro

Renato Candido de Lima 
1 - INT/DIA - ESCRITÓRIO

CRÉDITOS INICIAIS sobre imagens. MÃO NEGRA com lápis ESCREVE num papel palavras como "Diferencial emotivo", "Liderança", "Capacidade de Influenciar Pessoas". Som da escrita se destaca de várias pessoas falando uma seguida da outra. Olhos de RICARDO, alto, 31 anos, negro, vestido socialmente, dirigem-se às pessoas que falam.

\section{PESSOAS (off) (entrecortado)}

Acredito que o principal mesmo é o Diferencial Emotivo, entende? Aliado a isto... (corta) Mas uma palavra que me resume é Motivação! (corta)

PESSOAS, algumas jovens, estão vestidas socialmente e se apresentam entre si e para uma pessoa de crachá no peito, que anota sempre que alguém fala. Cortes na imagem ficam cada vez mais rápidos.

\section{PESSOAS (entrecortado)}

Liderança não se impõe, se conquista. (corta) A pró-atividade, para mim é essencial... (corta) Eu planejo minha vida pessoal e a minha carreira, evito surpresas. (corta) Atualização constante e Inteligência Emocional, eu me orgulho porque tenho essas duas qualidades. (corta)

\section{RICARDO}

(off) Eu? (corta para Ricardo) Eu sou Ricardo.

PESSOAS olham para Ricardo, a pessoa com crachá pára de escrever.

RICARDO
Ricardo Elias do Nascimento.
(respira para falar algo).

Ricardo olha para o papel que escreveu e pigarreia. Créditos cessam e entra título do filme.

2 - EXT/DIA MANHÃ - PORTA DE EDIFÍCIO E CALÇADA

Sai título do filme. Ricardo, sério, sai do pórtico de um edifício comercial de luxo. Ele olha a folha de papel que escrevera, amassa-a e a joga no lixo. Ao caminhar, Ricardo pára numa banca de jornal, confere um tablóide 
amarelo de empregos e o compra. Ao sair, Ricardo repara em algo e retorna lentamente a banca. Ricardo olha para uma REVISTA intitulada "E-BUSINESS", na capa está a foto de LARISSA, 32 anos, negra, vestida de roupa social. Sob sua foto está o título "A Nova Face da Executiva Feminina". Ricardo pega a revista, folheia-a e lê uma matéria em que se têm fotos de Larissa. Ricardo sorri levemente.

$$
\begin{aligned}
& \text { JORNALEIRO } \\
& \text { Vai levar, rapaz? } \\
& \text { RICARDO (pensa) } \\
& \text { Er... Não, não... obrigado! }
\end{aligned}
$$

Ricardo devolve a revista e sai. Ao lado, Ricardo abre seu automóvel relativamente novo, carro liga e parte.

\section{3 - INT/DIA MANHÃ - QUARTO DA CASA DE LARISSA}

Pacote translúcido com FOTOS sobre o colchão sem lençóis. Ao lado, diversas outras caixas de papelão contendo roupas, cabides, pastas, sapatos e papéis. Sobre a penteadeira, uma mala de maquiagem semi-aberta com perfumes e maquiagem arrumados. Na parede, diplomas com o nome "Larissa Pereira Lima" em cursos como Graduação em Marketing, MBA - Tecnologia da Informação, MBA - Carreira e Liderança. Som reverberado de mulheres conversando e de tilintar de colher em caneco de porcelana.

$$
\text { LARISSA (off-reverberado) }
$$

O que eles disseram?

LOURDES (off-reverberado)

Pediram desculpas, você sabe né! Mas hoje eles virão sem falta. Onze horas. Dizem que o caminhão quebrou ontem.

\section{LARISSA (off-reverberado)}

Tsc! Vai atrasar um monte de coisa...

$$
\text { LOURDES (off-reverberado) }
$$

Ah, a festa você pode dar outro dia!

$$
\text { LARISSA (off-reverberado) }
$$

Não! Tem que ser hoje! Eu já chamei buffet, comprei champanhe... 


\begin{abstract}
Entendi...
4 - INT/DIA MANHÃ - CORREDOR DA CASA DE LARISSA

Plásticos-bolha envolvem alguns móveis. LOURDES, 59 anos, pouco gorda, negra, de óculos pendurados no pescoço, adentra ao corredor arrastando seus chinelos. Ela abre a gaveta de um pequeno móvel e retira um PACOTE embrulhado como presente.
\end{abstract}

INT/DIA MANHÃ - COPA/COZINHA DA CASA DE LARISSA

LARISSA, maquiada e compenetrada, vê fotos de uma casa de alto padrão em seu LAPTOP e bebe café num caneco. Pequena mensagem Pop-up aparece na tela, está escrito "Reunião Geral" $10 \mathrm{~h}$ e 30min. É um pop-up amarelo, típico programa que simula um bloco de anotações amarelo (post-it virtual). Ao fundo está um site de email. Larissa cerra seu rosto e respira. Lourdes entra na cozinha.

\title{
$(o f f)$
}

Lourdes está de braços esticados segurando o presente em direção a Larissa.

\section{LOURDES \\ Parabéns, Filha!...}

Lourdes abraça Larissa e lhe entrega o presente. A mãe senta na cadeira. Larissa abre o presente, é uma caixa com livros e um pen-drive. Ao mesmo tempo, Larissa manipula seu Laptop.

\section{LOURDES \\ ...É um curso, Larissa!}

Lourdes ajeita roupa social de Larissa que folheia os livros e vê as capas dos livros. Larissa e Lourdes se olham.

\section{LARISSA}

(silêncio)... Curso do que, mãe?

Lourdes puxa seus óculos para colocá-los no rosto, ela lê um papel que tira da caixa.

\section{LOURDES}

É um Curso... Motivação profissional.

(Lê) Como utilizar a motivação no

trabalho, na carreira e na vida! 
Legal né? (sorri para Larissa)

Larissa, séria, olha para Lourdes. Em seguida, Larissa sorri muito levemente em resposta ao sorriso da mãe. Celular bipa e Larissa lê a tela de seu celular, apertando botões dos dígitos. Lourdes termina de sorrir e olha para os lados. Larissa desliga seu Laptop e o guarda na mochila. Larissa veste a mochila e sai da cozinha, acompanhada de sua mãe que leva o presente que dera a sua filha.

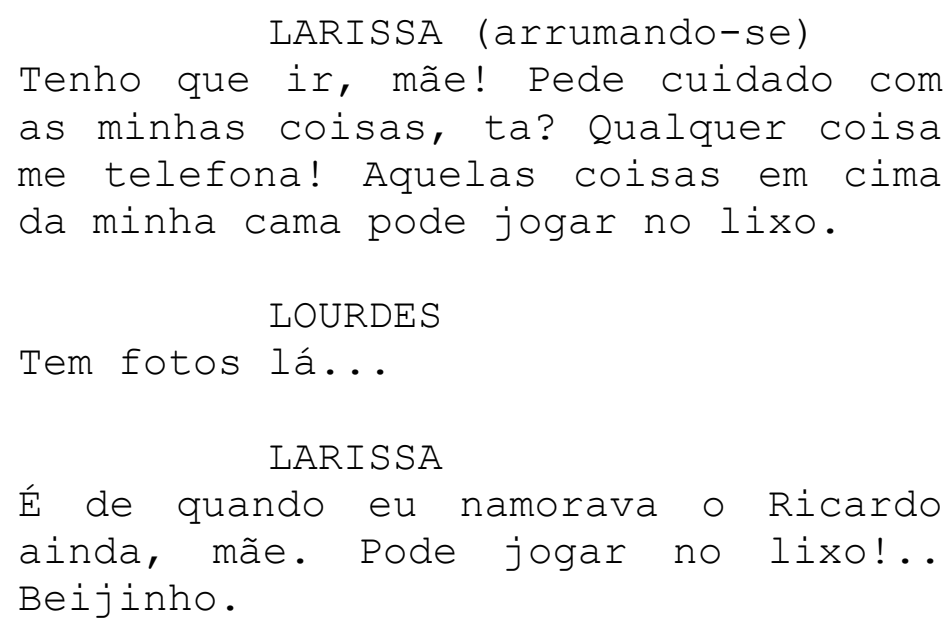

Lourdes beija testa de Larissa e saem pela porta.

5 - EXT/DIA MANHÃ - VARANDA/GARAGEM DA CASA

Lourdes e Larissa caminham até CARRO VERMELHO DE LUXO. Lourdes cumprimenta casal de idosos negros que saem do portão na casa a frente. Larissa entra no CARRO VERMELHO DE LUXO, ela olha para mãe e para a casa, Larissa suspira e olha para baixo. Lourdes entrega o presente que dera a filha. Larissa levanta o rosto, pega o presente, liga o carro. Porta automática de garagem se abre, carro sai. Entra som de carro em movimento.

6 - INT/DIA MANHÃ - CARRO DE RICARDO

Pelo vidro dianteiro de automóvel em movimento vê-se uma rua vazia ao lado de uma praça arborizada. Automóvel encosta e para. Ricardo olha para além do vidro dianteiro, ele sorri e sai do carro.

7 - INT/DIA MANHÃ - CARRO DE LARISSA

Mão negra feminina insere pen-drive em porta USB de rádio automotivo. Larissa dirige seu automóvel e olha para baixo, manipulando o rádio. Entra som de palestra sobre Carreira Profissional. 


\section{PALESTRA}

Marketing Pessoal é hoje a
ferramenta mais eficiente de fazer
com que seus pensamentos e atitudes,
sua apresentação e comunicação,
trabalhem a seu favor no ambiente
profissional...

\section{8 - EXT/DIA MANHÃ -PRAÇA-MIRANTE}

Ricardo caminha pela calçada lentamente e contempla o lugar. Ele se senta num banco de praça onde se vê uma grande montanha verde e a cidade abaixo. (corta) Ricardo, sentado no banco, lê um tablóide amarelo, mas em relances, pois contempla a praça. Entra som interno de automóvel em movimento.

PALESTRA (off)
Neste sentido, alguns detalhes
merecem atenção especial: Esteja
sempre pronto e capacitado para
enfrentar mudanças. Mantenha-se
motivado e controle suas emoções.
Mas não as anule, elas são muito
importantes para demonstrar o seu
envolvimento ou comprometimento com
o tema que está sendo tratado...

9 - INT/DIA MANHÃ - CARRO DE LARISSA

Mão negra feminina aperta botão "STOP" e retira pendrive, jogando-o displicentemente no porta-luvas. Larissa dirige seu carro e pelo vidro frontal vê-se a mesma praça que Ricardo está, inclusive o seu carro estacionado.

\section{0 - EXT/DIA MANHÃ - PRAÇA-MIRANTE}

Ricardo lê tablóide amarelo enquanto ao longe o carro de Larissa que se perde por entre ruas laterais. Ricardo se levanta e deixa tablóide amarelo sobre o banco da praça. Ricardo olha em torno da praça e sai.

\section{1 - INT/DIA MANHÃ - CARRO DE LARISSA}

Sons de buzinas e carros em marcha lenta. Mão de Larissa manipula Celular, em sua tela se exibe "Estou a caminho" e em seguida "Mensagem enviada". Batidas no vidro, Larissa se assusta. Do lado de fora, um vendedor de rua negro retira um pacote de balas do retrovisor, Larissa recusa e movimenta seu carro pelo trânsito carregado. 
12 - EXT/DIA MANHÃ - RUA DA CASA DE LARISSA

Ricardo tranca a porta de seu carro. Ele caminha poucos passos até a frente de uma casa relativamente simples, Ricardo aperta a campainha, ninguém o atende. Ricardo bate palmas. Som de caminhão estacionando (sirene de aviso para marcha a ré). Ricardo se vira e vê a casa de Larissa do outro lado da rua onde CAMINHÃO DE MUDANÇA estaciona de ré. No muro da casa há uma PLACA escrita "Vende-se". Ricardo caminha até o portão da casa de Larissa.

13 - INT/DIA MANHÃ - SAGUÃO DA EMPRESA / BLOQUEIO DE ENTRADA

MARCELA, 2 anos, morena e magra caminha atrás de Larissa e a olha seriamente. Larissa, caminhando, não a vê. Larissa passa seu crachá pela catraca, Marcela se aproxima.

MARCELA

Bom dia, Larissa!

Tarcela!

Oi, Marcela!

Elas se cumprimentam e sorriem ligeiramente.

MARCELA

Parabéns pelo seu aniversário!

LARISSA

Obrigada, Marcela!

Marcela entrega uma pequena caixa de presente a Larissa, que agradece. Larissa entrega um cartão a Marcela e as duas adentram a um elevador.

\section{LARISSA}

Vai lá no meu aniversário! Na minha nova casa. O endereço tá aí!

INT/DIA - CORREDOR ENCARPETADO DA EMPRESA

Marcela e Larissa caminham juntas. Marcela entrega uma pasta a Larissa, que demora a pegar, mas agradece e confere. Larissa abre porta dupla com uma placa escrita "Sala de Videoconferência".

14 - INT/DIA - SALA DE VIDEOCONFERENNCIA DA EMPRESA 
Numa mesa de reuniões, funcionários vestidos socialmente e com enfeites de aniversário se levantam, aplaudem Larissa; inclusive ÁLVARO, 50 anos, grisalho, branco, baixo, magro, através de um TELEVISOR DE VIDEOCONFERENCIA.

\section{5 - EXT/DIA - PORTA DA CASA DE LARISSA}

No portão, Ricardo bate palmas. DOIS CARREGADORES da mudança, negros, descem do caminhão e vão ao portão, também batem palmas. Lourdes vai ao portão rapidamente e os atendem de rosto cerrado.

Que demora!...

LOURDES (bronca)

Ricardo e os entregadores se olham. Lourdes abre o portão.

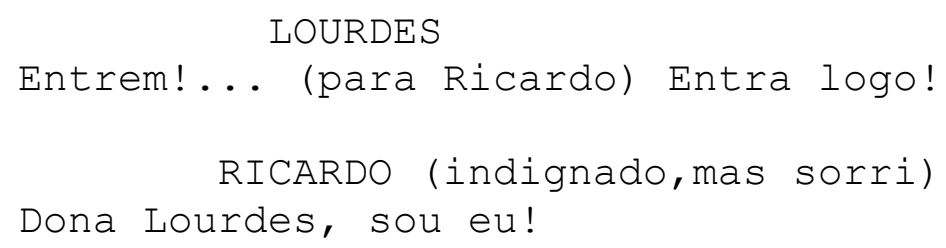

Lourdes olha para Ricardo, estranha-o, mas logo ela esboça um ligeiro sorriso. Ricardo sorri.

16 - INT/DIA - SALA DE VIDEOCONFERENNCIA DA EMPRESA

Larissa, sorrindo ligeiramente, entrega cartões aos funcionários(as) que retiram seus enfeites de aniversário e pegam seus objetos de trabalho como papéis, iPhones e/ou laptopes.

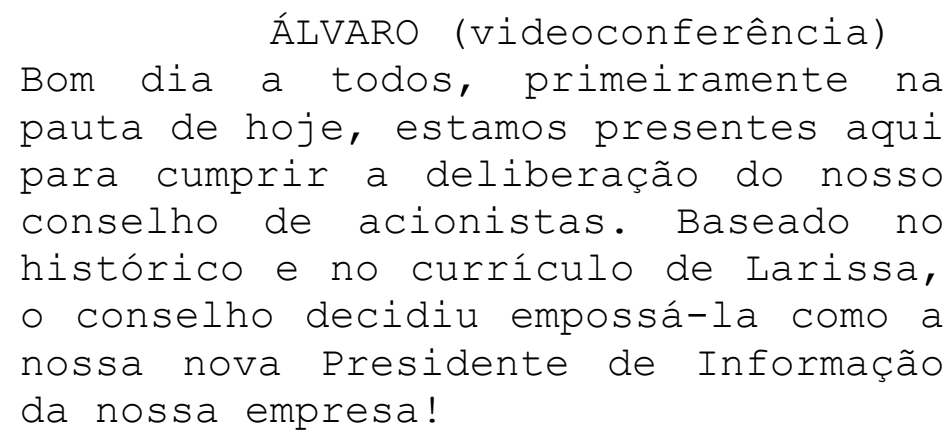

Silêncio. Funcionários se olham. Um deles aplaude, logo todos aplaudem e sorriem. Larissa agradece, não mais sorri. 
Mudou muita coisa por aqui, Dona

Lourdes.

17 - INT/DIA - CORREDOR DA CASA DE LARISSA

Ricardo, observando, percorre o corredor da casa a frente de Lourdes. Ao fundo, carregadores empilham caixas. Lourdes pára e junta pequenos enfeites envoltos em plástico. Ricardo adentra sozinho ao quarto de Larissa.

18 - INT/DIA - QUARTO DE LARISSA

Ricardo olha para os diplomas de Larissa.

LOURDES (off) (empolgada)
Verdade. Você que não mudou muito,
Ricardo! Belo Horizonte te fez bem...
RICARDo
Ah, é?
É! Tá menino ainda!.. Voltou a morar
aí em frente?

\section{RICARDO}

(ri) Obrigado! (..) Sim e não. Cheguei hoje praticamente! Mas é por pouco tempo. Não quero atrapalhar muito meus pais de novo, sabe? Quero meu cantinho próprio. Você sabe se eles saíram?

Ricardo olha para o corredor, Lourdes ajeita objetos. Ricardo olha para caixote amassado de papelão com roupas, papéis, revistas. Ao lado, Ricardo olha para pacote translúcido de fotos sobre a cama e o pega. Lourdes adentra ao quarto.

\section{LOURDES}

Acho que saíram sim, por quê?

\section{RICARDO}

Eu esqueci a chave de casa. Eles saíram e eu fiquei de fora.

Ricardo abre pacote e retira fotos.

LOURDES

Hehehe. Lembra quando você tinha uns doze anos? 


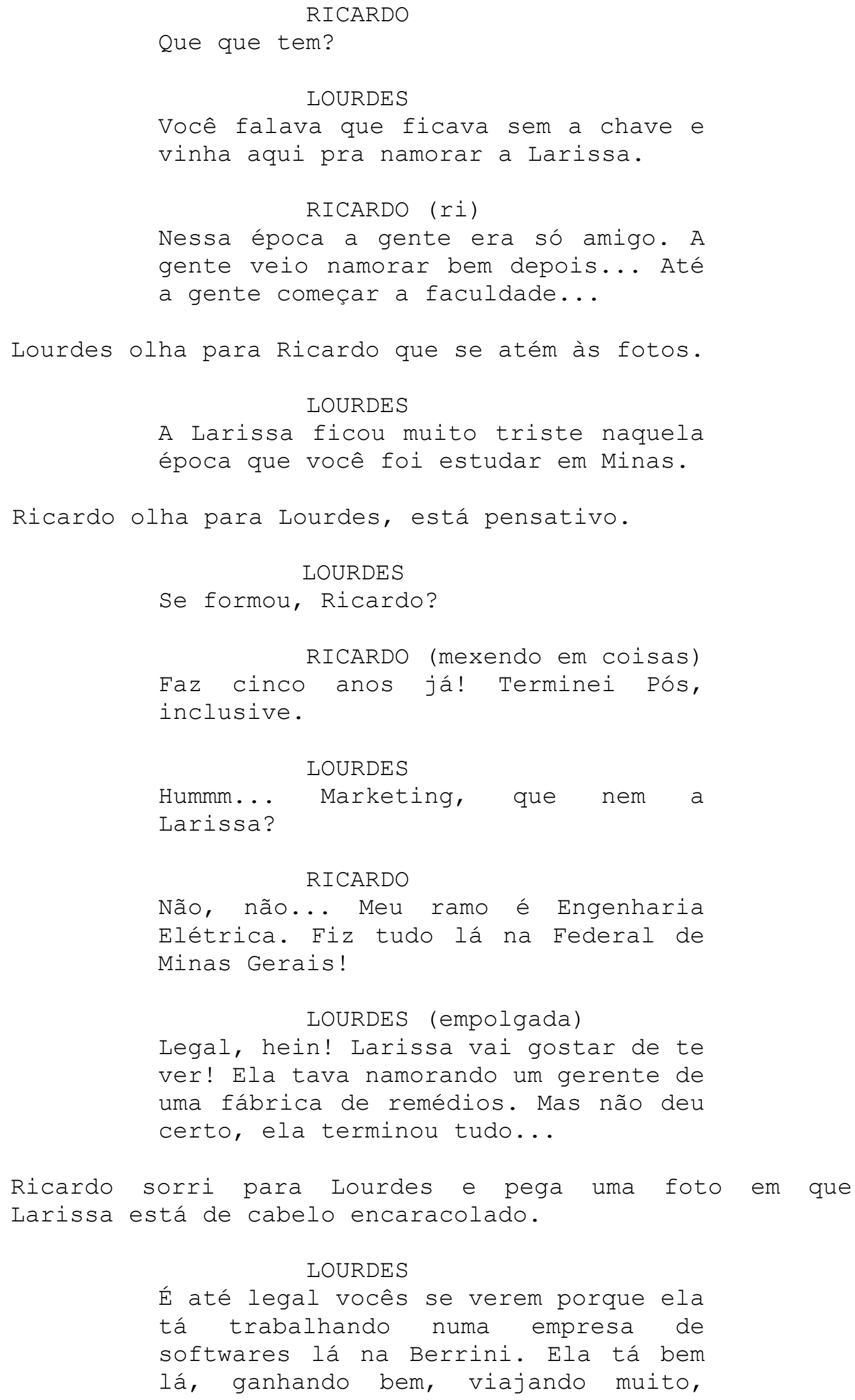

Ricardo sorri para Lourdes e pega uma foto em que Larissa está de cabelo encaracolado.

LOURDES

É até legal vocês se verem porque ela tá trabalhando numa empresa de softwares lá na Berrini. Ela tá bem lá, ganhando bem, viajando muito, 


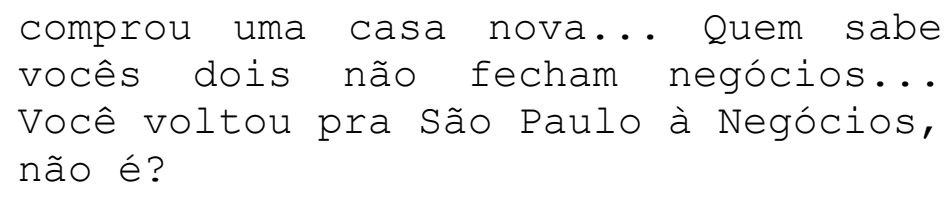

Ricardo ri, Lourdes cerra o rosto como se não entendesse.

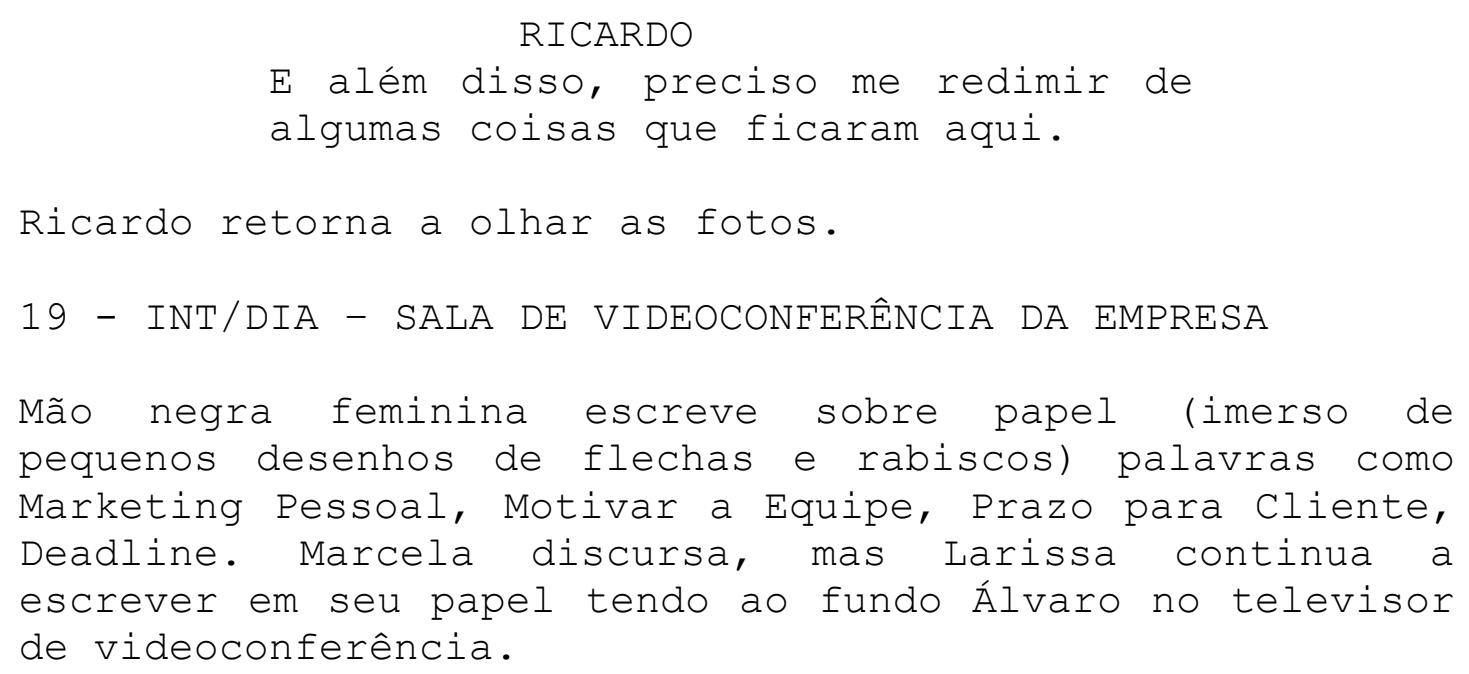

\section{MARCELA}

(off) E como se trata de um software robusto, para banco, o prazo exequível para término dos testes (imagem de Marcela) é de uma semana. Pelo menos assim é como nossa equipe estipula no cronograma.

\section{LARISSA}

Uma semana a mais é impossível, Marcela.

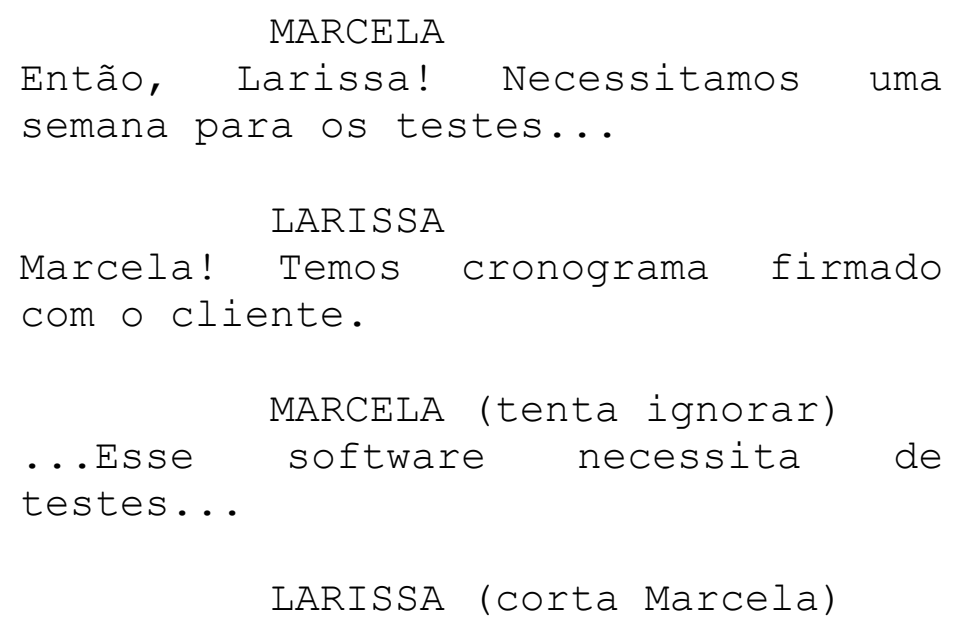


Menina, o cliente é banco. Compreende a responsabilidade! Se não compreende, não tem porque estar aqui.

MARCELA (nervosa)

- que não compreendo foi o cronograma que vocês estipularam.

\section{LARISSA}

Não quero discutir com você novamente. Segunda-Feira software pronto e testado. Esse é o desafio. Se nós somos uma equipe, temos de encarar esse desafio! Uma semana a mais é impossível. (corta Marcela) Testem o software aqui no final de semana. De noite, de dia, que seja! Segunda-feira esse software estará funcionando e pronto para a reunião com o cliente, entendeu?

Funcionários(as) anotam ou desviam olhares. Silêncio. Alguém pigarreia. Alguns guardam cartões nos bolsos. Marcela e Larissa se encaram.

ÁLVARO (videoconferência)
(off) Bom, er... (imagem de Álvaro no
Televisor) Faço as minhas palavras as
palavras de Larissa e declaro
encerrada esta reunião!...

Todos se levantam. Silêncio. Cadeiras arrastadas sobre carpete. Faxineiras, negras, entram na sala e limpam confetes da mesa. Funcionários saem.

$$
\text { RICARDO (off) }
$$

Eu senti que eu não fazia parte daquilo, Dona Lourdes. Daí eu saí. Acho que sempre foi assim.

20 - INT/DIA - QUARTO DA CASA DE LARISSA

Ricardo, rosto cerrado, retira uma foto do pacote translúcido. Na foto, Ricardo e Larissa estão juntos numa praça sob a luz poente do sol. Ricardo vira o verso da foto onde está escrito (Caligrafia de Larissa) "Simples Assim". 
Humm, que pena, Ricardo! Mas a Larissa pode te ajudar em algo. Agora ela é gente importante lá na empresa.

Lourdes sobe na cama para pegar algo numa prateleira.

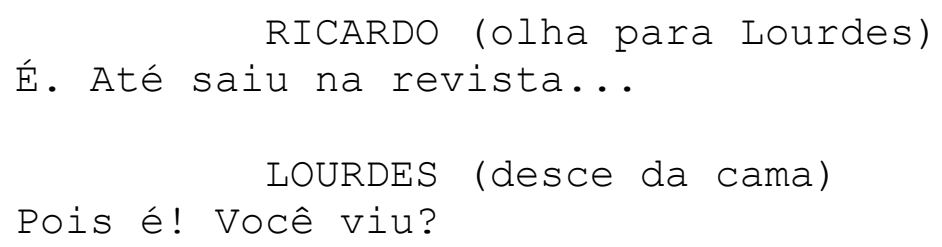

Ricardo gesticula positivamente e guarda a foto no bolso. Ricardo vai a Janela, ao lado está uma penteadeira.

\section{LOURDES}

Sua amiga tem futuro! Seguiu as coisas tudo direitinho! E seguindo assim, não tem erro!

RICARDO

Ela aprendeu muito...

Silêncio. Ricardo pega seu aparelho celular.

RICARDO

Qual é o celular da Larissa?

LOURDES

Ah, Ricardo! Er... Eu não lembro! (para Carregador) Não moço, esse daí vai em outra caixa...

Lourdes sai do quarto. Ricardo olha para uma agenda telefônica sobre a penteadeira e folheia. Letra L. Lá está escrito "Larissa (Celular)" e o respectivo número. Ricardo digita seu celular.

\section{CELULAR}

Você não tem crédito suficiente para efetuar esta ligação...

Ricardo desliga seu celular e olha para telefone sem fio.

\section{PALESTRA (off)}

o modelo de sociedade em que vivemos dita padrões de competitividade 
$\begin{array}{llr}\text { extremamente } & \text { elevados } \\ \text { praticamente } & \text { todas as áreas. }\end{array}$

Pequenas diferenças podem determinar

- sucesso ou o fracasso.

21 - INT/DIA - ESCRITÓRIO DA EMPRESA/BÁIA DE LARISSA

Larissa, com fones de ouvido, digita algo em seu Laptop.

PALESTRA (over)

Talvez seja um modelo injusto, mas a realidade é que este é o modelo em que transitamos! O reconhecimento de competências e habilidades é fundamental para diferenciar e situar um indivíduo no contexto social em que vive. Determina-se assim a maneira como ele estará posicionado para o sucesso profissional e pessoal...

Dedos de Larissa param de digitar num Laptop. Larissa retira seus fones de ouvido e ejeta pen-drive que ganhara de sua mãe. Ao fundo, pessoas trabalham em suas báias, algumas estão pensativas. Larissa apresenta cansaço e mau humor; ela pega uma pasta.

INT/DIA - ESCRITÓRIO DA EMPRESA/BÁIA DE MARCELA

Marcela, numa das báias, está cabisbaixa e pensativa, ela fala ao telefone.

MARCELA

Não Rodolfo... A vaca da minha chefe me obrigou... Já! Já faz mais de dois meses que não tenho final de semana, Rodolfo! Essa preta filha da puta nunca mandou em ninguém na vida e agora tá realizando o sonho dela... Fica pra uma próxima vez... eu queria a gente juntos... Mas tenho que ficar nessa porra de software...

Marcela rabisca papel e enxuga lágrimas dos olhos.

INT/DIA - ESCRITÓRIO DA EMPRESA/BÁIA DE LARISSA

Larissa fecha uma pasta, suspira e vira sua poltrona em 
direção a enorme janela solar de vidro. Larissa contempla a paisagem da janela preenchida por enormes prédios empresariais luxuosos e também por uma grande favela que margeia avenida multipista e um rio escuro de poluição visível. Larissa olha para os funcionários em suas baias, quase todos digitam atentamente em seus computadores. Larissa termina de olhar em volta e se espreguiça, seu Celular vibra e se ilumina. Seu visor mostra escrito "MãeCasa" .

\title{
LARISSA
}

Oi mãe! (susto) Que! Quem é? Quem tá falando?

Larissa se assusta.

$$
\text { Ricardo da onde? }
$$

LARISSA (séria)

Silencio.

LARISSA (dúvida)

Ricardo?

Silêncio.

\author{
LARISSA \\ Ricardo!
}

Silêncio.

LARISSA

Ricardo...

Larissa esboça um sorriso.

22 - INT/DIA - QUARTO DA CASA DE LARISSA

Ricardo, de telefone sem fio na mão e sentado sobre um caixote, sorri e folheia fotos. Ao fundo no corredor, Lourdes entra no quarto e em seguida os carregadores de mudança.

$$
\begin{aligned}
& \text { RICARDO } \\
& \text { Depois de bater muito a cara por } \\
& \text { aí... eu tô aqui... }
\end{aligned}
$$

23 - INT/DIA - ESCRITÓRIO DA EMPRESA

Silêncio. Mão folheia páginas de agenda. Caneta percorre vários escritos de compromissos e pára onde está escrito 
"13h - Almoço". Larissa risca e escreve o nome de Ricardo.

\section{LARISSA}

Não vai fugir de novo, né! (sorri)

Faz tanto tempo Ricardo... Brigada, brigada (risos) Trinta e Dois!

Ricardo, ó, vamos... (silêncio)

Então, Ricardo, vamos...

24 - INT/DIA - QUARTO DA CASA ANTIGA DE LARISSA

Silêncio. Ricardo, a pedido dos carregadores, levanta-se do caixote e caminha a fim de encontrar outro lugar para não atrapalhá-los, não consegue.

RICARDO

...Vamos! Vamos sim! Você me espera?

Não. Você me espera, é melhor...

25 - EXT/DIA - ESCRITÓRIO DA EMPRESA

Silêncio. Ainda ao celular, Larissa recebe papéis de um funcionário, ela assina e devolve os mesmos.

\section{LARISSA}

Espero... Desta vez eu espero... (ela

sorri) Beijo! Tchau!

Larissa desliga celular. Entra som de talheres e pratos.

26 - INT/DIA - RESTAURANTE DE LUXO.

Sentado à mesa, Ricardo une dois garfos. Ele olha em seu relógio de pulso e vê as outras mesas com poucas pessoas, brancas, algumas o olham desconfiadas. Ricardo olha para as janelas; Larissa, de mochila, está do lado de fora olhando para dentro do restaurante. O rapaz acena, mas Larissa não o vê. Ricardo, constrangido, abaixa a mão e desune os garfos. Larissa, sorridente, aparece novamente numa das janelas e cumprimenta Ricardo. Ele olha, mas quando a cumprimenta, Larissa sai novamente. Ricardo se levanta e ajeita sua roupa. Larissa caminha de braços abertos em sua direção. Eles se abraçam.

\section{LARISSA}

Desculpa, Ricardo!

RICARDO (sorridente)

Tudo bem... Parabéns, Larissa! 
Brigada!

Sentam-se, olham-se. Larissa ajeita roupa de

Ricardo.Silêncio. Pessoas olham para Larissa e Ricardo. Larissa sorri.

LARISSA

Eu lembrei do dia em que você passou

na faculdade.

Ricardo se entristece.

\section{RICARDO}

Eu nunca esqueci desse dia...

\section{LARISSA}

Ricardo, desencana! Você tava certo mesmo. Foi melhor pra nós dois.

\section{RICARDO}

Melhor ou não, Larissa, eu não me esqueço!.. Quando eu vi meu nome na lista de aprovados, eu julguei que ao entrar na faculdade, eu tinha que me afastar de você... Principalmente no caminho que eu queria seguir.

\section{LARISSA}

Mas me afastar de você naquele momento foi importante pra mim também. Segui o meu caminho. E foi melhor para nós dois.

Ricardo olha em volta.

RICARDO

Er... Cê tá sozinha?

LARISSA (cabisbaixa)

Eu tô! (pensa) Eu tava namorando... Gerente de uma fábrica de medicamentos...

Ricardo sorri constrangido.

\section{RICARDO}

Eh, assim, eu perguntei se você tava sozinha... sozinha. Com o pessoal da empresa, entende? 
LARISSA (constrangida)

Ahh! (olha para os lados) Tô.

Celular toca. Garçom entrega cardápio à Larissa. Ela retira seu celular da bolsa e o lê. Ricardo pega o cardápio.

\section{LARISSA}

Fui promovida hoje! Presidente de TI!

(lê mensagem)

Larissa, lendo o celular, cerra seu rosto. Ela guarda seu celular na bolsa.

\section{RICARDO}

Você sempre foi talentosa, Larissa...

$\mathrm{Eu}$ vi que você promoveu de casa

também...

Larissa olha para Ricardo e sorri. Ela retira seu Laptop da mochila e o coloca na mesa. Laptop disputa espaço com pratos e copos ainda vazios. Larissa mostra fotos internas e externas de uma casa luxuosa.

\section{LARISSA}

É. (Pega Laptop) Essa é minha nova casa, olha! Aqui é a lareira! só esse daqui é o meu quarto... a sala... salão de festas. Vou fazer uma festa hoje à noite lá! (tira cartão) Dez horas da noite nesse endereço. Você pode ir que não tem problema!

Larissa pega convite da bolsa e o dá para Ricardo, que estranha.

RICARDO
E porque teria problema?

$$
\begin{array}{r}
\text { LARISSA } \\
\text { responder) } \\
\text { Não, por nada... }
\end{array}
$$

(demora

a

Larissa fecha Laptop e olha para Ricardo.

\section{LARISSA}

Por que você voltou, Ricardo?

Negócios? 
Larissa cerra o rosto para Ricardo, demonstra dúvida.

RICARDO

Saí daquela empresa lá de Belo

Horizonte...

\title{
LARISSA
}

Que pena! (pensa) Er... vai ter algumas figuras importantes na minha festa de aniversário. Quem sabe eu não consigo te fazer uma boa rede de contatos? Marketing Pessoal, entende? Aliás...

Larissa retira da bolsa a revista em que ela está na capa. Ela abre numa página em que o título é "Você já fez um MBA?".

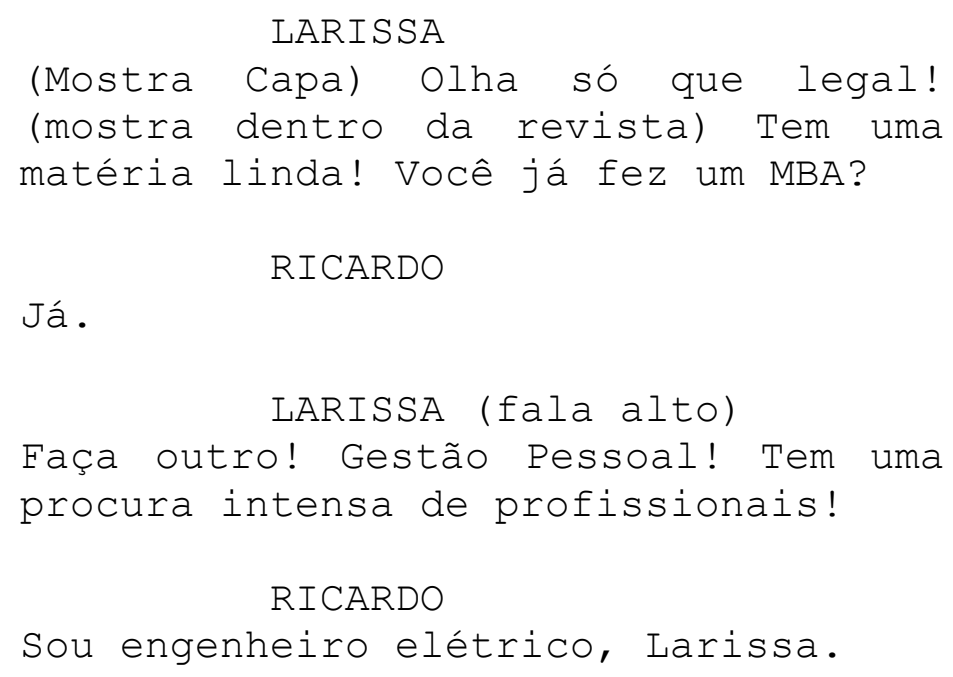

Ricardo tira do bolso uma foto em que os dois estão numa praça ao pôr-do-sol e a entrega para Larissa. Ela contempla a foto sob o olhar de Ricardo. Garçom chega. Larissa olha para o Garçom e para Ricardo. Ele aponta algo no cardápio para o Garçom, que anota o pedido e sai.

\section{RICARDO}

... Lembra?

Larissa olha a foto.

\author{
RICARDO \\ (pensa) Quem que tirou a foto?
}

Larissa pega foto com a mão. Silêncio. 
(pensa) A máquina?

Larissa sorri constrangida. Ricardo cerra o rosto, em dúvida.

LARISSA

Era automática... (relembra) Eu penava. A gente colocou no banquinho da praça, não tinha tripé... Eu não sabia como a máquina funcionava... Mas nesse dia a gente descobriu o mecanismo pra fazê-la funcionar...

Ricardo olha a foto e Larissa. O Casal se olha. Ricardo pega a foto.

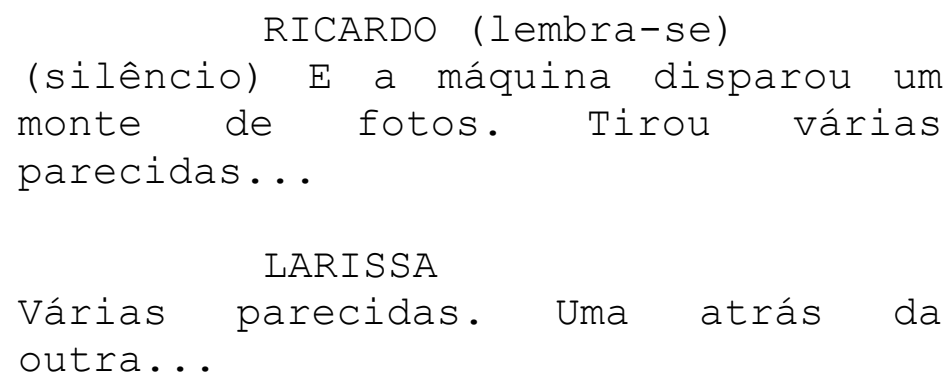

Larissa atende seu celular enquanto Ricardo fala.

\section{LARISSA \\ Alô! Oi, só um momento...}

Ricardo olha seu relógio de pulso e se levanta. Larissa permanece sentada.

RICARDO

Cê me desculpa, Larissa. Tenho uma outra entrevista de emprego daqui a pouco.

LARISSA

A gente se vê a noite? (atende) Alô, 
só um momento... A gente se vê a noite, Ricardo?

RICARDO

Err... amanhã, eu... eu vou ter uma

outra entrevista de emprego...

Larissa se levanta. Ela olha para Ricardo e para seu celular.

\section{LARISSA}

Mas amanhã é sábado! Ricardo!

Ricardo sorri e se despede. Ele deixa a foto e sai da mesa.

\section{RICARDO}

Parabéns, Larissa!

Ricardo sai do restaurante. Ao fundo e em pé Larissa olha para Ricardo. Garçom traz taças e um balde de gelo com champagne. Entra som de música eletrônica.

27 - INT/NOITE - NOVA CASA DE LARISSA/CORREDOR

Som de música eletrônica povoa o ambiente. Larissa, vestida elegantemente, mas não de gala, caminha pela casa com pessoas dançando, conversando e algumas vezes cumprimentando-a. Um senhor elegante e embriagado entrega em cartão a Larissa.

\section{HOMEM}

Parabéns, Larissa! José Mondego. Meu contato! Vamos se falar! Negócios!

Homem ri. Larissa lê o cartão. Homem se afasta. Larissa passa por um cômodo, num dado momento ela retorna e esboça entrar nele, mas é Lourdes quem sai de lá.

INT/NOITE - NOVA CASA DE LARISSA/SALA DE ESTAR

Lourdes, sorridente e vestida elegantemente, caminha junto de Larissa cumprimentando a todos. Lourdes abraça a filha bruscamente e alguém tira foto. Larissa entrega o cartão recebido para Lourdes.

\section{LOURDES}

Você chamou o Ricardo, filha?

LARISSA

Ele não vai vir! 


\section{LOURDES \\ É melhor! Melhor assim...}

Lourdes ajeita a roupa que Larissa veste. Marcela e outros funcionários que estavam na reunião abordam Larissa abraçando-a em roda. Marcela dá uma caixa de presente a Larissa. Ela abre, trata-se de uma cela com chicote. Larissa cerra seu rosto e encara Marcela. Pessoas riem. Lourdes, sorrindo, pega rapidamente o presente e o deixa sobre uma mesa. Álvaro, um tanto alcoolizado e de mãos dadas a uma jovem modelo negra, abraça Larissa.

\section{ÁLVARO}

Larissa! Gosto de você mandando, viu! Aprendeu tudo melhor que a gente.

Termina abraço. Álvaro olha Larissa de cima a baixo e sorri. Larissa encara Álvaro. A jovem modelo negra sorri para Larissa. Ao fundo, Lourdes puxa Larissa para uma mesa com bolo de velas faiscantes. Luzes se apagam. Faísca das velas com os números dois e nove iluminam algumas pessoas.

Todos
Parabéns pra você, nesta data
querida, muitas felicidades, muitos
anos de vida! E pra Larissa nada!
(apaga vela) Tudo... Então como é que
é? (alguns gritam) É pica, é pica! É
pica-pica-pica! É rola, é rola, é
rola-rola-rola! No bumbum! Larissa!
Larissa!

Velas se apagam. Escuro. Luzes se acendem. Larissa não está na festa. Todos param de cantar e de bater palmas.

28 - INT/MADRUGADA - CARRO (ENTRECORTES)

Larissa chora. Ela dirige por avenidas com vários prédios empresariais de alto luxo. Garota faz malabarismo com bolas de tênis a frente do carro, ela pede dinheiro, Larissa desce o vidro do carro. Elas se olham.

\section{9 - EXT/DIA AMANHECENDO - RUA DA CASA DE LARISSA}

Céu está mais claro, mas sol não alvoreceu. Larissa sai do carro, ela está a frente de sua casa. Ela olha rapidamente para sua antiga casa e olha, em seguida, para a casa a frente da sua onde o carro de Ricardo está 
estacionado na garagem. Larissa caminha enxugando o rosto. Ela ameaça tocar campainha da casa de Ricardo, mas alarme do carro de Larissa começa a tocar. Larissa se atrapalha para desligar o alarme, mas desliga-o. Larissa ameaça retornar a campainha, mas desiste e sai a pé. $\mathrm{Na}$ casa, o vitrô se ilumina e sombra aparece no vidro do vitrô.

30 - EXT/DIA AMANHECENDO - PRAÇA COM MIRANTE

Larissa caminha pelo gramado, ela tem lágrimas nos olhos e cruza os braços, sente frio. Ela se senta no gramado da praça e olha para o horizonte. Larissa pega um tablóide amarelo de empregos sobre um banco e o coloca sobre a grama para assentar-se. Larissa contempla a cidade que desliga suas luzes de ruas enquanto amanhece. Ao fundo, Ricardo, vestido de moletom, caminha e olha o nascente. Larissa olha para Ricardo, ele a olha. Ricardo chega. Larissa retira algumas folhas do tablóide e as entrega para Ricardo. Ele se assenta ao lado de Larissa e os dois voltam a olhar o horizonte. Larissa tira do bolso a foto que Ricardo entregara a ela. Eles se olham, olham a foto, sorriem. Como na foto, os dois contemplam o amanhecer que ilumina uma grande montanha verde sobre inúmeros prédios e bairros abaixo.

CRÉDITOS FINAIS 
2.3 Menina Mulher da Pele Preta - Episódio 3: Simone - Estórias em Estação de Transferência

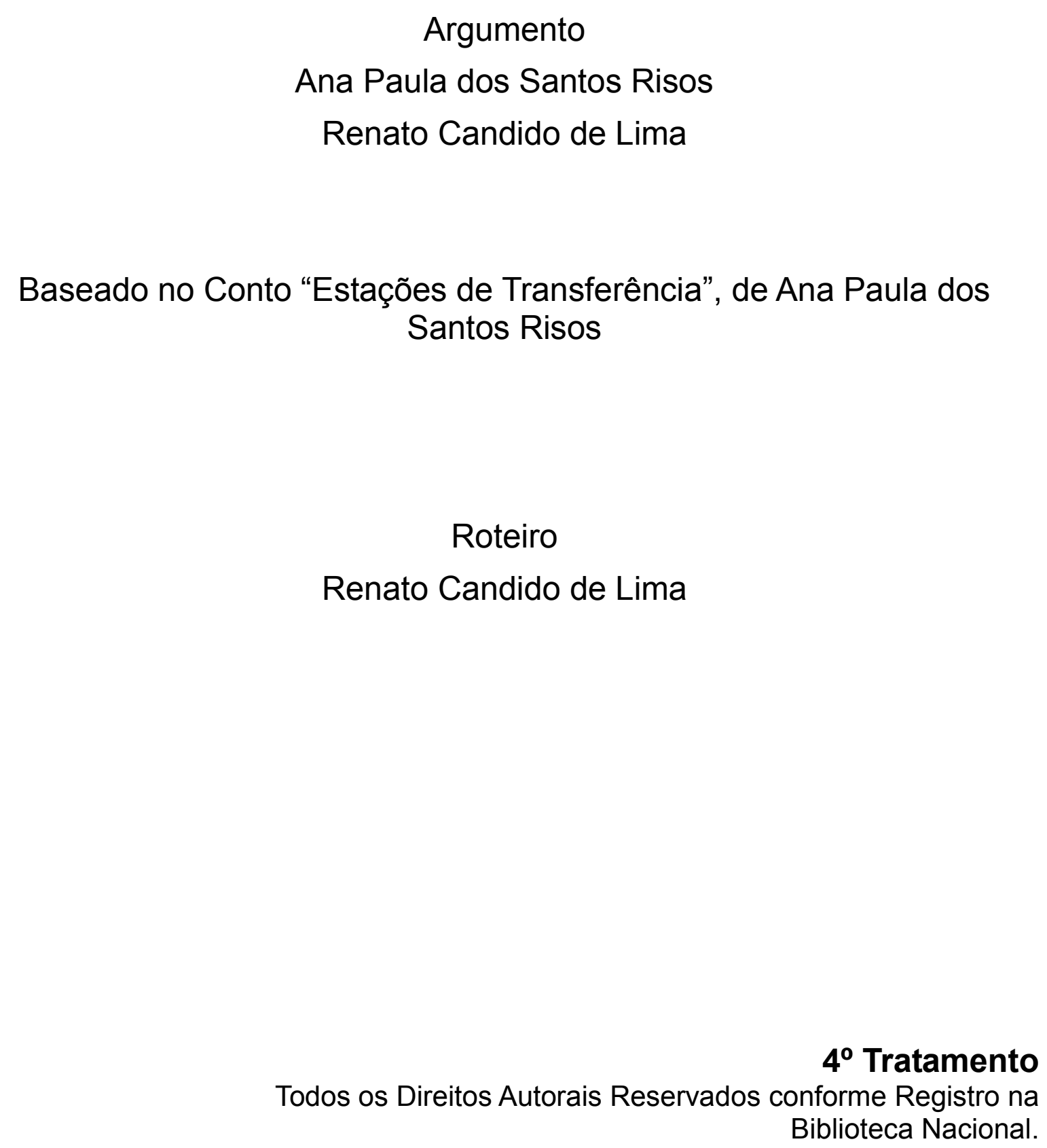


1 - INT/DIA - VAGÃO DE TREM SUBURBANO - REGISTRO ESBRANQUIÇADO

Créditos emergem sobre a imagem. Luz do sol tem tonalidade esbranquiçada, como se o tempo estivesse a se nublar. SIMONE, 20 anos, negra, cabelos crespos, baixa, veste calça jeans azul e blusa simples vermelha que agarra seu busto e cobre seus ombros, está sentada ao lado da janela do Trem.

Simone pega um pequeno pacote com bala de menta e olha para seu caderno. Ela guarda o pequeno pacote de bala na bolsa.

Vemos seus olhos olhando através desta janela e olhando para baixo: ela escreve algo num caderno que está sendo apoiado por sua mochila. Sua mão vacila no sacolejo do trem. No caderno está escrito dentre outras coisas a frase "Botei batom na boca! Bala bastava." seguidas vezes.

SIMONE (narração)

Gostaria de escrever uma estória. A

estória da minha personagem. Simone!

Simone é o nome da minha personagem.

Olhos de Simone desviam da janela e olham para o espectador.

SIMONE (narração)

Simone é negra.

MULHER 1, negra, gorda, aparentando ter 30 anos, está em pé segurando-se no balaustre do vagão.

SIMONE (narração)

Tem seus vinte e poucos anos... Está

cansada das oportunidades em

telemarketing...

MULHER 2, negra, jovem, magra dorme em seu assento e tem fones no ouvido.

SIMONE (narração)
Cansada do transe, do trânsito, de
dentro do Dois sete zero quatro,
Jardim Robru - Itaquera; Simone
resolveu pegar o trem. Inesperado
para aquela hora... atenderia
telefonemas de clientes furiosos no
trabalho. Mas aqui o telefonema foi


outro. Seus dedos digitaram. Sua decisão. A coragem do amor, de amar foi determinante para estar ali, naquela estação, naquele momento...

2 - INT/DIA - VAGÃO DE TREM SUBURBANO - REGISTRO AMARELO

Imagem solar. O amarelo do sol inunda a paisagem em movimento de bairro suburbano. No caminho se vê linha de trem com alimentação elétrica aérea. Passa trem de pantógrafo, é um trem prateado-azul-vermelho.

\section{SIMONE (narração)}

Foi radiante a ideia daquele sim...

Não importava lugar, lugar algum, mas

sim... Assim... Naquele sim, o

telefone, pela voz dele... Dentro

daquele sim, os dois... num só.

Encontro.

Aos poucos paisagem é percorrida pouco mais lenta. Agora é possível ver plataforma de estação de trem suburbano, pessoas nela e uma faixa laranja com nome da estação de trem suburbano "Corinthians Itaquera". Trem para e vemos Simone, ela leva uma mochila nas costas, alça num ombro só, e fala ao celular. Simone entra no vagão e se assenta ao lado da janela onde o sol a ilumina.

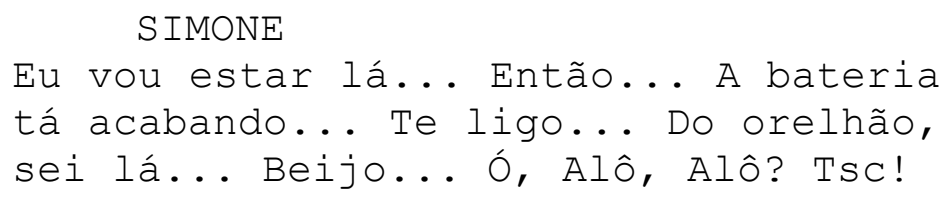

Nesta imagem, Simone esta disposta inversamente da primeira vez que a vemos. Trem parte, Simone guarda celular dentro de sua mochila.

SIMONE (narração)

Tomar a atitude traz seus encantos...

Tanto... só pra ter um pouco do tudo

entre os dois... Tanto...

Simone olha seu reflexo na janela. Ela mexe seus lábios e tira uma necessaire da mochila, suas mãos passeiam por pó básico, rimmel, curvex. Encontra um batom. Ela o pega, abre-o, mas o cosmético não tem mais ponta para passar nos lábios. Simone se olha novamente no reflexo da janela, mexe seus lábios e desiste do batom, jogando-o na necessaire. Ela continua a mexer na necessaire e deixa cair um preservativo. 


SIMoNE (narração)
Medo de amar tanto. Por que não
resolveu amar os outros? Seria mais
fácil! Seria? os outros homens! Será
que com ele (imagem de rapaz no trem)
seria mais fácil? Entenderia estes
lábios propondo carinho?... Por que
esperar dele a decisão para os dois
no amor?

Simone, apreensiva, olha para frente. Muda de feição, pega o preservativo sem constrangimento. Na janela, procura o relógio da torre de uma igreja, mas desiste e Simone tenta ver relógio de HOMEM 1, rapaz moreno claro que está em pé no vagão, não consegue. Simone nota num braço branco com relógio, esta pessoa está sentada ao seu lado, ela olha e percebe que esta pessoa é HOMEM 2, moreno claro, calvo, gordo, aparentando 50 anos. Ele a olha e sorri demonstrando interesse em Simone.

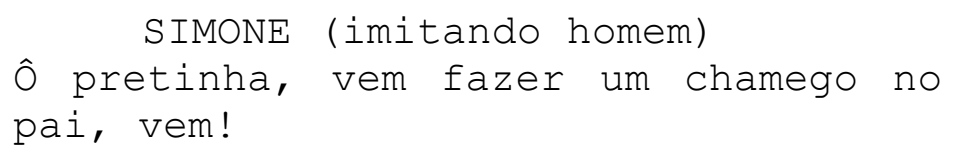

Imagens em still fotográfico. HOMEM 2, sentado ao lado de Simone, tem seu braço direito sobre os ombros da moça. Ele a olha. Simone o empurra com seus dois braços.

SIMONE (narração)
Simone tinha más lembranças de homens
aproveitadores das carnes novas.
Lembrou de seu padrasto morto,
acariciador dela... Maldito!

Imagem em movimento. HOMEM 2 olha Simone em relances. Simone olha para paisagem da janela.

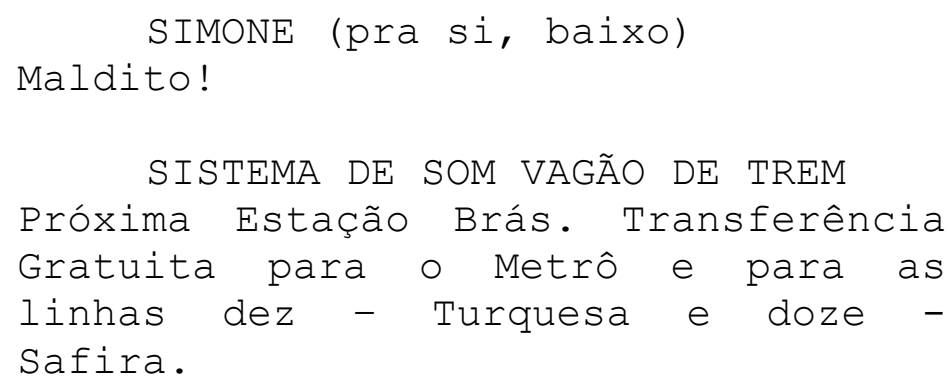

SISTEMA DE SOM VAGÃO DE TREM

Próxima Estação Brás. Transferência

Gratuita para o Metrô e para as

linhas dez - Turquesa e doze -

Safira.

Simone se levanta rapidamente.

3 - INT/DIA PLATAFORMA DE ESTAÇÃO DE TREM - TRANSFERÊNCIA 
Trem Suburbano chega na estação, abre suas portas, muitas pessoas saem dele.

\author{
SIMONE (narração) \\ E se para ele, Simone não soubesse \\ dizer não?
}

Simone sai do trem e caminha com a multidão.

INT/DIA - PLATAFORMA / ESCADA ROLANTE

Próxima a escada rolante, Simone vê a si própria carregando duas crianças, uma de colo e outra pela mão. Ao lado está HOMEM 3, negro, cabelos lisos, que aparenta embriaguez. Simone com as crianças olha para Simone com a mochila. As duas Simones vestem a mesma roupa.

HOMEM 3 gesticula de forma ríspida para Simone-Mãe a fim de subir a escada rolante. O casal sobe a tal escada rolante com suas crianças. Simone-Mãe demonstra tristeza. Simone-Jovem a vê. Simone-Mãe se perde entre a multidão. Simone-Jovem permanece olhando para cima, como se ainda buscasse se ver. Pessoas caminham ao lado dela. Simone começa a caminhar e sobe na escada rolante. Ela se perde em meio a multidão.

\title{
SIMONE (narração) \\ Lapidar pessoas brutas é um talento. \\ Mas Simone está cansada.
}

4 - INT/DIA - FRENTE DE LOJA EM ESTAÇÃO DE TREM SUBURBANO

Simone se vê num espelho de uma loja de bijuterias da estação. Ela passa suas mãos em seus cabelos, revelando ainda mais suas orelhas sem brincos.

INT/DIA - CATRACAS DE PASSAGEM

Simone procura algo na mochila e se encosta na parede ao lado da grande fileira de catracas da estação. Transeuntes passam, alguns poucos olham para Simone. Mulheres, Homens, Mães. Alguns homens olham para Simone e a paqueram de longe. A Moça direciona sua atenção da mochila para a catraca. HOMEM 4, loiro, alto, magro, vestido de camiseta T-Shirt e calça jeans passa pela catraca. Ela se enfadonha, olha para suas unhas e as morde. 
5 - INT/DIA - PASSAGEM DE ESTAÇÃO - "TEATRO DE RUA"

HOMEM 5, traços negros, mas com maquiagem branca no rosto e peruca loira, veste indumentária aristocrática que remete ao início do século XIX, tem lentes de contato azuis, aproxima-se de Simone.

\section{HOMEM 5}

Por que a pergunta? Semeei e colonizei esta terra! Todas amam um homem como eu! Estou nas revistas, nas novelas, na sua imaginação, no consumo de uma imagem que você nunca será!

Homem 5 abraça carinhosamente Simone, os dois caminham próximo a fileira de catracas, mas não as atravessam.

HOMEM 5

Veja meus olhos azuis! Veja em mim a Europa, a civilização e o poder na minha brancura! Eu sei! Você quer embranquecer, eu sei! E eu tenho a certidão, a posse e o passaporte para isto! Nossas crias nascerão mais brancas, poderão passar despercebidos pela Polícia. Seus netos? Imaginou? Terão vaga herdada na Universidade! Naquelas de nome, renome e sobrenome! Imagine você, avó de garotos que parecem santinhos, anjinhos de olhos azuis! Você! Dos mais bestiais e animistas orixás, poder beliscar nossa brancura, nosso poder... (sorri) Eu? Eu quero seu sexo, essa sua magia que você tem por entre suas pernas, coxas, bunda, tetas, sua pele, sua facilidade para atender os meus desejos... de um homem como eu!

HOMEM 5 leva Simone para mesa de jantar situada próxima a catraca. Transeuntes olham, o palco é semelhante a teatro de rua. Lá estão MULHER 3, traços negros mas com maquiagem branca, de peruca loira e lentes de contato azuis, magra, aparentando 50 anos, vestida com roupa de luxo que remete ao início do século XIX e HOMEM 6, traços negros com maquiagem branca, aparentando 50 anos, magro, vestido de indumentária aristocrática do início do século XIX. 
HOMEM 5

Veja papai, veja mamãe! Que exemplar exótico eu trago para Nossa Casa! Nossa Grande Casa, nossa Grande Casa Grande! Ganhei minha mulata, papai! Dê um sorriso para meus pais, minha mulatinha linda!

HOMEM 4 pega região da boca de Simone e força a moça a mostrar os dentes.

MULHER 3
Que dentes lindos! Tem saúde de uma
Égua! E suas mãos? Afeitas aos
serviços da Nossa Casa Grande!
HomeM 6
que herdou muito bem nosso
legado, meu filho!

HOMEM 5 sorri para HOMEM 6. Em seguida HOMEM 5 olha sorrindo para Simone.

\section{HOMEM 5}

Sim, papai! Desde os primeiros passos! Sinto-me pronto para exercer meu poder para que meus pais, minha família e meu país se orgulhem de mim!

Simone joga conteúdo de jarra em HOMEM 5 e sai da mesa.

SIMONE (narração)

Negra para estar em sua casa, mas mulata para estar em sua cama.

CORTA PARA

6 - INT/DIA - CATRACAS DE PASSAGEM

Simone, encostada na parede, se assusta. Ela vê HOMEM 7, negro de tranças, cruzar a catraca. Ela corre em direção ao rapaz.

SIMONE (grita)

André! André!

Simone se aproxima do rapaz e o pega pelo braço. Rapaz a olha. Simone gesticula desculpas. 
Foi mal, moço!

Simone retorna, mas muda o caminho para a loja de bijuterias presente na estação e vê alguns brincos e correntes.

7 - INT/DIA - LOJA DE BIJUTERIAS

Simone digita máquina de cartão de crédito. Mãos brancas femininas coloca brincos de argolas e batom em lado branco de papel presente.

\title{
SIMONE (off) \\ Precisa não, moça.
}

Mão negra de Simone leva brinco até sua orelha. Simone sai da loja.

8 - INT/DIA - CATRACAS DE PASSAGEM

Simone caminha e pega algo do bolso de sua calça. É um batom. Ela abre e passa por seus lábios. Seus lábios espalham o batom.

\section{ANDRÉ (off)}

Simone morde seus lábios. A Moça vira seu rosto. Frente a frente estão Simone e André, 20 anos, negro, alto, cabelo black, veste roupas largas que remete a visual Hip-Hop. Ele se aproxima e a abraça, sem apertá-la.

\author{
ANDRÉ \\ Simone, você é linda como uma rosa. \\ Nosso amor é belo.
}

André larga Simone e abraça MULHER 4, negra, jovem, vestido longo e decotado que sorri. André a abraça como se dançasse com ela.

\section{ANDRÉ}

Seus olhos têm a cor do ébano. E sua pele é a mais linda.

André larga MULHER 4 e abraça dançando com MULHER 5, morena clara de cabelos lisos e vestido curto.

\section{ANDRÉ}

Ninguém é de ninguém. Mas te quero!

Também! 
André baila com MULHER 6 de pele clara, cabelos escuros e vestido decotado colorido.

\title{
ANDRÉ
}

Sei que sou ator de pouco mérito. Interpreto a vida em vários braços

André abraça Simone por trás dela como se dançasse.

\section{ANDRÉ}

Mas vivamos intensamente este nosso

momento! Eu, você, todas vocês!

André puxa rosto de Simone.

CORTA PARA

\section{9 - INT/DIA - CATRACAS DE PASSAGEM}

Simone, em pé, ouve musica em seus fones de ouvido ao lado da catraca. Ela se balança ao sabor da música. Ela vê André ao longe antes da catraca. Simone sorri, suspira, leva as mãos a boca como se tentasse fazer um cone para potencializar seu grito, desiste. Simone acena para André. O rapaz a vê, mas não esboça reação intensa senão um balançar de cabeça confirmando que a viu. André chega e a beija rapidamente na boca com um selinho.

\author{
ANDRÉ \\ Simone! \\ SIMONE \\ Ô, André! Foi difícil pra você \\ chegar?...
}

ANDRÉ

Simone, eu queria lhe dizer que gosto de você. Mas você não me ama.

Simone cerra seu rosto.

\section{ANDRÉ}

Você ama a ideia de me transformar... um sujeito bruto, naquilo que você deseja... Mas eu encontrei uma outra garota. Ela é muito mais bonita que você! Ela é loira!

Simone ameaça chorar e falar algo, mas André a corta. 
ANDRÉ

Meu, não começa. É com ela que tô agora e com ela que quero estar! É importante para mim! Entende?

Simone olha André seriamente. Voz de André se mistura a voz feminina de aviso de sistema de som da estação

ANDRÉ E SISTEMA DE SOM

Você é mó carente, Simone! Eu não conseguia ser eu mesmo com você do meu lado! Você é mó zuada, seus cabelos são horríveis! Você se veste mal, eu tinha vergonha de sair com você, você é feia! Você tem cheiro de fritura, de empregada! Eu tenho dó você! E por essa dó é que eu lhe digo isto!

Simone encara André. Os dois estão frente a frente na imensidão da estação.

CORTA PARA

10 - INT/DIA - CATRACAS DE PASSAGEM - IMAGEM BRANQUIÇADA

Imagem com luz mais esbranquiçada. Simone dorme sentada ao chão apoiada pela parede próxima a catraca. Som de buzina de trem. Simone acorda.

EXT/DIA - LOCOMOTIVA NOS TRILHOS

Locomotiva a diesel passa.

INT/DIA - CATRACAS DE PASSAGEM

Vemos relógio que marca 16 horas. Simone olha para relógio, olha para passageiros da estação.

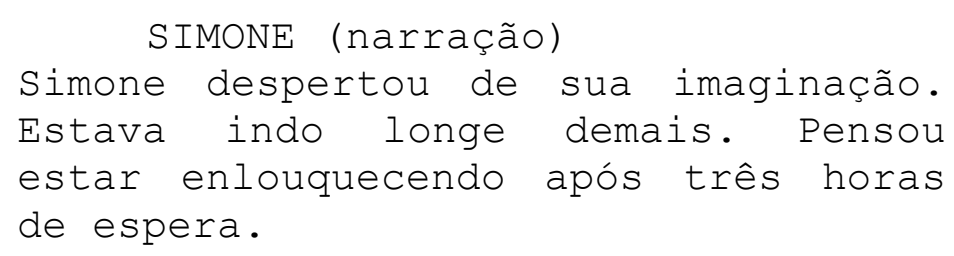

Simone retoca seu batom, pega mochila e sai.

11 - INT/DIA - PLATAFORMA DE TREM DE SUBURBIO

Sol ilumina com luz mais branca, como se estivesse o céu entre nuvens. Trem Suburbano chega na estação. Ao longe 
Simone entra no vagão, que fecha suas portas e parte.

SIMONE (narração)

Botei batom na boca. Bala bastava.

12 - INT/DIA - VAGÃO DE TREM

Simone escreve em seu caderno. Nele há a frase "Botei batom na boca! Bala bastava.".

SIMONE (narração)

Botei batom na boca. Bala bastava.

13 - EXT/DIA - SUBURBIO

Trem Suburbano percorre bairro ao lado de avenida movimentada.

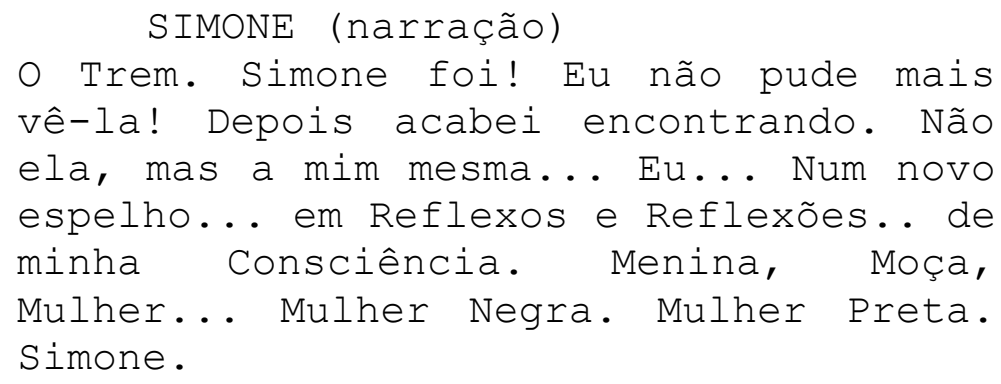

CORTA PARA PRETO

Créditos Finais.

FIM 
2.4 Menina Mulher da Pele Preta - Episódio 4: Dara - A Primeira Vez Que Fui ao Céu

\author{
Argumento \\ Elizandra Souza (Mjiba) \\ Renato Candido de Lima
}

Baseado no Conto "A Primeira Vez Que Fui ao Céu", de Elizandra Souza (Mjiba)

Roteiro

Renato Candido de Lima 
Para Abbas Kiarostami, Jafar Panahi e Família Makhmalbaf 
1 - INT/DIA - CARRO

Pelo vidro de um Carro, vemos a paisagem agrestina da Bahia. O caminho é de terra e num dado momento, avistamos uma árvore muito grande. É um cajueiro. Dara Senhora, 65 anos, negra, cabelos grisalhos, vestido claro, dirige este automóvel pela estrada de terra. Ela olha pelo vidro do carro e vê ao longe os frutos amarelos deste grande cajueiro. Créditos emergem sobre a imagem.

\section{2 - EXT/DIA - CAJUEIRO}

Sob sol forte, um Caju balança no galho da árvore. Vemos suas folhas, galhos, alguns deles com formigas ou outros invertebrados. Venta leve, som das folhas da árvore.

EXT/DIA - CAMINHO AO LADO DE CAJUEIRO

Dara Senhora sai do carro e olha para...

EXT/DIA - CAJUEIRO

...árvore de caju que tem um balanço feito de cordas e tábua de aspecto antigo. O balanço balança levemente com o vento.

EXT/DIA - CAMINHO AO LADO DE CAJUEIRO

Dara Senhora olha para árvore e olha para baixo, lágrimas saem de seus olhos fechados. Som de passos de animal com casco.

3 - EXT/DIA - CAMINHO AO LADO DE CAJUEIRO

Sol forte, Dara, 9 anos, cabelos trançados vestida com vestido branco com detalhes em desenhos a mão de joaninhas, caminha carregando um jumento por uma corda. No jumento há cesta com fibras de sisal. Dara caminha ao longe e se aproxima de uma porteira.

4 - EXT/DIA - TERREIRO DA CASA DE ADOBE

Menina 1, negra, 8 anos, vestida de calça e camiseta corre atrás de Menina 2, negra, 7 anos, com vestido longo amarelo.

5 - EXT/DIA - ALPENDRE DA CASA DE ADOBE

No Alpendre, espaço exterior da casa, mas coberto com telhas e lastros de madeira; Vó, 60 anos, negra, lenço na cabeça, dobra roupas sobre um tamborete (pequeno tronco 
que se assenta uma pessoa) e as coloca numa mala antiga.

6 - EXT/DIA - JANELA DA CASA DE ADOBE

Dara está sentada no enquadramento de uma janela verde numa casa de tijolos de adobe caiados de branco. Ela trança palhas de sisal, formando uma corda. Dara olha para algo ao horizonte.

EXT/DIA - PORTEIRA E CAMINHO DE TERRA

Vô, 63 anos, negro, carregando uma enxada e um saco de pano (ou balde) se aproxima.

EXT/DIA - TERREIRO E JANELA DA CASA DE ADOBE

Dara, trançando palha, olha para Vô.

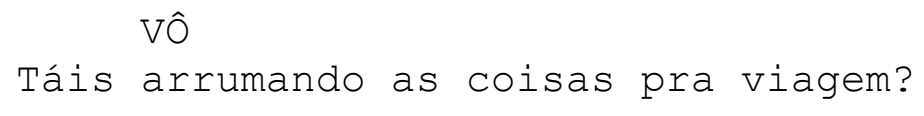

Vô olha Dara. Ele a consola e sai, dirigindo-se ao alpendre da casa.

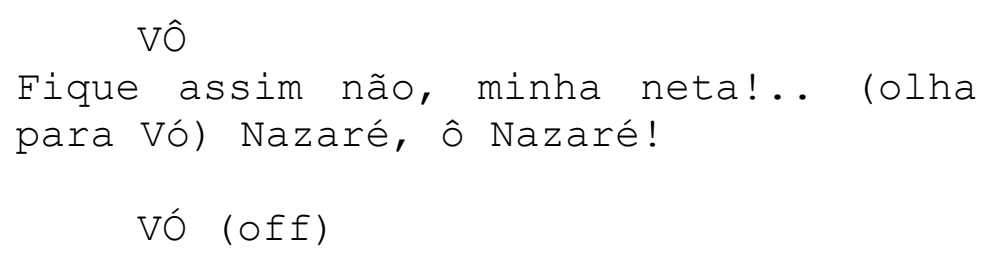

Dara acompanha vô com olhar. Ela estica uma das cordas que fez, olha para a mesma direção em que Vô está e sai da janela.

7 - EXT/DIA - ALPENDRE

Dara se aproxima de Vô, que ajeita as coisas que ele carrega. Vó ajeita roupas na mala.

DARA

Vô, você fez aquela tabuínha?

Vó (intervém)

Tabuínha do que? 
DARA

Daquela de colocar no meu balanço, Vó!

VÔ

Ah, Dara! Deve de tá por aí...

DARA

Queria levar daqui...

VÓ

Bobagem, Dara! Lá em São Paulo tá assim de balanço...

VÔ (sorri)

...Mas querendo a tabuínha, ela deve

de tá no celeiro.

Dara olha para seus avós, Vô ajeita saco e enxada, Vó ajeita roupas na mala. Dara sai e Vó a acompanha com olhar. Vó cerra seu olhar.

8 - INT/DIA - CELEIRO

No celeiro, onde estão jumento, uma vaca e uma mula, Dara pega uma tábua retangular furada em quatro pontos próximos aos vértices.

9 - EXT/DIA - JANELA DA CASA DE ADOBE

Dara pega cordas feitas de sisal e sai.

EXT/DIA - TERREIRO

Dara caminha, carrega as cordas e a tábua. Ao fundo Menina 1 e Menina 2 brincam de correr uma da outra.

MENINA 1

Onde cê vai? Vamo brinca no pega-pega, Dara!

DARA

Não, depois!

Dara caminha para fora do terreiro e sai pela porteira.

EXT/DIA - CAMINHO

Dara caminha por um caminho de terra.

EXT/DIA - CAMINHO AO LADO DE CAJUEIRO 
No galho de uma árvore, uma corda bate e cai. Dara, embaixo, da árvore joga a corda que cai novamente. Dara olha pra uma pedra pouco maior que duas mãos juntas e amarra a corda.

Dara joga a pedra amarrada com a corda, mas a pedra não chega a altura do galho. Ela tenta algumas vezes, não consegue, até que a pedra bate no galho, mas cai no chão.

Dara se aborrece, mas pega a pedra e olha para o galho. Ela respira e joga a pedra, que passa pelo galho. Dara pega a corda dupla e festeja. Dara se pendura na corda e balança.

\section{Vó (off)}

Vó está em pé e parada olhando aborrecida para Dara.

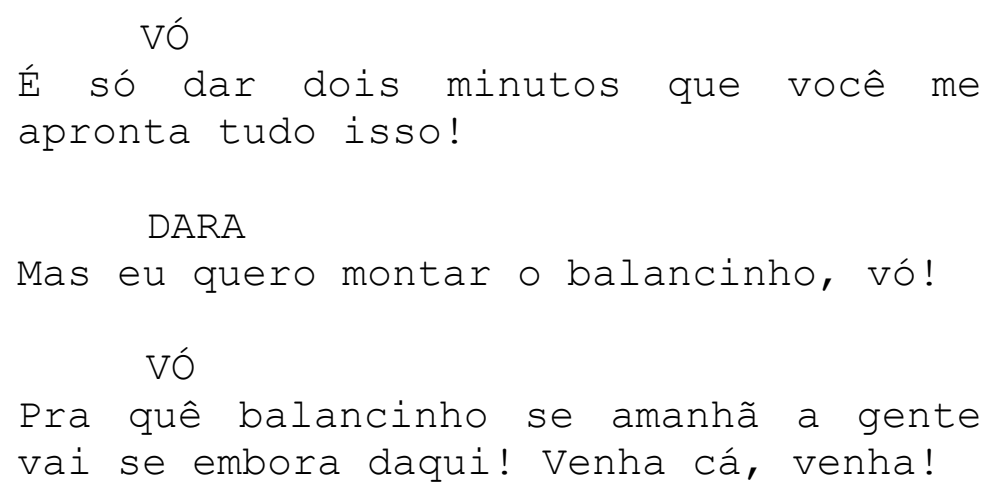

Vó, brava, pega na mão de Dara e a leva para a casa. Pedra com a corda fica; ao fundo, Dara olha para trás, mas caminha junto a sua avó.

$$
\text { Vó (ao longe) }
$$

Cê podia ter se machucado!

10 - EXT/DIA - CASA DE ADOBE

No enquadramento do espaço de janela verde há apenas o escuro do espaço interior.

$$
\text { VÓ (off) }
$$

Vai ficar aí pensando no que fez!

Som de porta batendo. Som de animais grunhindo e cantando. Som de Menina 1 e Menina 2 brincando.

$$
\begin{aligned}
& \text { Vó (off, ao longe) } \\
& \text { Vocês também, é hora de parar! }
\end{aligned}
$$


Dara surge na janela e vê a paisagem.

11 - EXT/DIA - PAISAGEM SOLAR

Ao longe na paisagem está o Cajueiro. Homem com carro de boi coloca galinhas em gaiolas sobre a plataforma, este Homem é ajudado por Vô e Vó. Pássaros voam no céu. Nuvens tem algumas formas. Pássaros estão pousados no beiral do sítio e na porteira. Homem paga Vô e sai.

12 - EXT/DiA ANOITECENDO - ANOITECER

Planeta Vênus está no céu. Grilos começam a cantar.

13 - INT/NOITE - COZINHA

Sob a luz de lampião, Vó, Vô, Dara, Menina 1 e Menina 2 estão a mesa para a janta. Todos estão de mãos dadas e oram.

TODOS

Ave Maria, cheia de graça, o senhor é convosco. Bendita sois vós entre as mulheres. Bendito o fruto do vosso ventre, Jesus... Santa Maria, Mãe de Deus, rogai por nós pecadores, agora e na hora da nossa morte. Amém!

VÔ

Agradeço ao alimento que o senhor nos deu através desta terra, da água e desse sol para esta família. Amém.

Dara, faz rapidamente o sinal da cruz com a mão esquerda. Vó, Vô, Dara, Menina 1 e Menina 2 jantam.

DARA

Vó, por que a gente vai embora?

VÓ

Você não tem saudade da mãe, do pai?

DARA

Tenho, mas eles podiam voltar de São Paulo!

VÓ

São Paulo é uma terra boa, Dara. É

lugar de emprego, é lugar de futuro... 
É Fria...

VÔ

VÓ

A gente vai viver melhor lá do que aqui... Antes que a gente acabe perdendo tudo... né não Dé?

VÔ

É Nazaré, infelizmente... tem que tá na cidade pra esperar Zé do Caminhão?

VÓ

Zé passou aqui de manhã e disse que não precisa ir na cidade não. Ele passa aqui pelas nove da manhã...

Dara olha para seus avós.

14 - SALA DA CASA DE ADOBE

Rádio transistorizado de pilhas toca programa radiofônico. Vó e Vô guardam objetos em malas e maletas. Vô desliga rádio e o guarda numa maleta.

15 - INT/NOITE LUA CHEIA - QUARTO

Dara guarda brinquedos e boneca de pano num embrulho de pano. Ela pega um retrato em preto e branco em que ela está ao lado de um casal relativamente jovem. Dara guarda - retrato num pequeno baú, que ela também coloca no embrulho de pano.

Dara caminha até a janela.

16 - EXT/NOITE LUA CHEIA - PAISAGEM NOTURNA

Faz Lua Cheia. Paisagem tem brilhos brancos.

17 - INT/NOITE LUA CHEIA - QUARTO

Dara fecha a Janela e vai para a cama, olha para Menina 1 e Menina 2 que dormem, e apaga lampião de querosene e se deita na cama de palha.

18 - EXT/NOITE DE LUA CHEIA - TERREIRO

A Luz da Lua Cheia ilumina o Terreiro, a Cerca de pau e arame e, ao longe, o Cajueiro.

19 - INT/NOITE DE LUA CHEIA - QUARTO 
Réstia de Luz branca-azulada ilumina Dara, acordada e deitada na cama. Esta luz é branca-azulada. Ela se vira na cama, morde suas unhas.

20 - EXT/AMANHECER - PAISAGEM

Passarinhos cantam. Nuvens ralas se mesclam a imagem do céu em linhas de azul e magenta. Galo canta.

21 - INT/DIA AMANHECENDO - QUARTO

Dara acorda e se levanta. Ela abre a janela sutilmente e a pula. Do lado externo, Dara fecha a janela.

22 - EXT/DIA AMANHECENDO - CAMINHO

Dara corre pelo Caminho após a porteira.

23 - EXT/DIA MANHÃ - CAMINHO AO LADO DE CAJUEIRO

Dara recolhe corda e tábua. A Menina amarra uma pedra na corda e tenta jogar por um dos galhos. Pedra amarrada numa corda bate em galho do cajueiro. Sem Sucesso.

Dara olha para o chão procurando algo. Ela revira outras pedras leves.

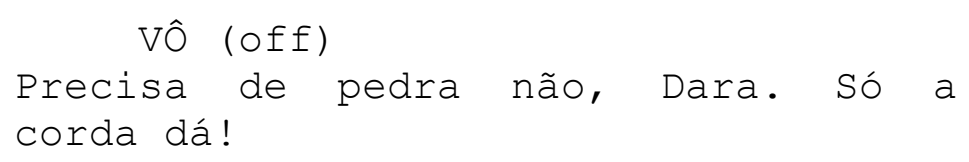

Dara se assusta. Vô se aproxima de Dara.

Vô desata nó de corda na pedra e suas mãos negras enrugadas fazem nó corrediço em duas cordas. Vô joga corda sobre galho. Dara joga a outra corda sobre o mesmo galho. A corda passa.

VÔ

Te falei?

Vô passa as duas cordas pelos quatro furos da tábua e dá nó numa das cordas.

Dara olha para cima e olha para Vô, que está em pé ao lado da menina. Dara caminha.

Dara se senta no banquinho do balancinho. Ela olha para seu avô. 
VÔ

Só toma cuidado com as lagartas de fogo e não coloque os pés no chão, Dara, você pode cair.

Vô caminha para trás de Dara.

$$
\text { VÓ (off) }
$$

Dé! Venha cá que o Zé do Caminhão chegou mais cedo, homem!

Ao longe, Vó está no caminho de terra e se afasta. Vô a acompanha.

$$
\begin{gathered}
\text { VÔ } \\
\text { Vá pegar suas coisas, Dara. }
\end{gathered}
$$

Dara desce do banquinho e acompanha Vô e Vó.

24 - EXT/DIA - TERREIRO DA CASA DE ADOBE

Dara carrega pano que Zé do Caminhão, 41 anos, moreno, de barba, coloca na caçamba do Caminhão modelo anos 60 . Vô sobe malas e maletas. Vó sobe com Menina 1 e Menina 2 no caminhão.

Dara sobe sozinha na caçamba e em seguida Vô sobe também.

Caminhão dá a partida. Fumaça preta sai do escapamento. Caminhão com família de Dara e outras pessoas saem do Terreiro da Casa de Adobe.

25 - EXT/DIA - CAMINHO

Caminhão passa pelo caminho.

26 - EXT/DIA - CAÇAMBA DO CAMINHÃO

Dara olha para um ponto fixo, desviando seu olhar conforme o movimento do caminhão.

27 - EXT/DIA - CAJUEIRO

Imagem de Cajueiro em movimento. Aos poucos, ele se apequena na paisagem.

$$
\text { VÔ (off) }
$$

Dara...

28 - EXT/DIA - CAÇAMBA DE CAMINHÃO 
Vô olha para Dara.

$$
\text { Um dia a gente volta... }
$$

Dara enxuga seus olhos com as mãos.

29 - EXT/DIA - CAMINHO DO CAJUEIRO

Dara, já senhora, enxuga seus olhos com uma das mãos. Ela olha Cajueiro com balanço e caminha se aproximando. Dara senta no banquinho. Testa sua consistência ao balançar o banquinho do balanço. Em seguida, Dara começa a balançar timidamente.

Mão negra masculina empurra Dara Senhora. É Vô quem empurra. Dara olha para trás e Vô empurra Dara Senhora cada vez mais intenso.

A imagem de Paisagem a frente se movimenta para baixo e para, mostrando céu e galhos do cajueiro e para cima, mostrando chão e raízes.

Vô empurra Dara Criança no balanço.

Numa imagem junta ao movimento do balancinho. Dara Criança balança, sorri, olha para trás, seu avô lhe empurra.

Vô empurra Dara Criança.

Ao longe, Dara Senhora balança no balanço sem a presença de Vô.

CORTA PARA

PRETO

Som de corda rangendo no galho. Entram créditos do filme. 


\title{
2.5 Menina Mulher da Pele Preta - Episódio 5: Deolinda
}

\author{
Argumento e Roteiro
}

Renato Candido de Lima 
Para Krzysztof Kiéslowski 
TELA PRETA

Entra trilha sonora e Créditos iniciais.

1 - EXT/NOITE - QUINTAL DE CASA LUXUOSA

CRISTIANE, 24 anos, negra, cabelos longos, alta, olha para algo que incendeia intensamente. Cristiane, com lágrimas nos olhos e séria, olha para os lados e, em seguida, para frente, como se encarasse o espectador.

2 - INT/NOITE - AUDITÓRIO

DEOLINDA JOVEM, 23 anos, negra, cabelos encaracolados, está vestida de beca negra e capelo negro de formatura. Ela segura um canudo de formatura. Na imagem em leve movimento, Deolinda Jovem olha como se encarasse o espectador.

$3-$ EXT/DIA - AVENIDAS

Sai trilha sonora. Viaturas de polícia percorrem uma avenida. Numa delas é possível ver uma mulher negra de cabelos soltos. Ela está cabisbaixa.

\section{APRESENTADOR DE TV(off)}

Já chegaram com a assassina? Já chegaram com a assassina? Cadê a assassina? Põe na tela! Essa assassina! Matou, tacou fogo no noivo e no filho dele, é uma monstra! Olha a cara dessa monstra! Essa Cristiane vai pegar no mínimo cem anos de cadeia! Cadeia pra uma monstra como essa! o, o Newton tá na porta do tribunal, tem mais detalhes da chegada! Newton?

4 - EXT/DIA - ESTACIONAMENTO DE ENTRADA DO TRIBUNAL

A imagem tem aspecto de jornalismo televisivo e tem grafismo em gerador da caracteres em que está escrito "JULGAMENTO DE CRISTIANE, A ASSASSINA QUE QUEIMOU VIVA SUAS VÍTIMAS". Três viaturas de polícia chegam ao estacionamento de entrada do tribunal. Policiais civis femininas retiram Cristiane, agora com 29 anos, da viatura, ela está vestida de camiseta branca larga e calça amarela. Repórteres avançam sobre cristiane, fotógrafos tiram fotos dela, que se esconde dos flashes. Logo atrás de Cristiane, caminha ADRIANA, negra, 32 anos, vestida socialmente, que carrega pasta e bolsa. 


REPÓRTER DE TV
Isso mesmo, Wagner! As viaturas tão
chegando no local... (para alguém no
local) peraí, por favor, é o trabalho
da imprensa... por favor! Cristiane!
Cristiane! Você acredita na sua
inocência?.. Tá chegando a advogada
de defesa... Adriana! Uma palavrinha
pra TV! Adriana! Você vê chances na
absolvição da sua cliente? Adriana?..

5 - INT/DIA - SALA ESCRITÓRIO DE DEOLINDA

Numa sala-escritório com mesa, armário-biblioteca, escaninhos e cadeira acolchoada, DEOLINDA SENHORA com 52 anos, retira toga do armário e a ajeita em seu corpo. Ela tem seus óculos pendurado no seu pescoço.

6 - INT/DIA - CORREDOR DO TRIBUNAL

Fundo sonoro de conversa de pessoas adultas. Cristiane é levada por duas policiais militares judiciárias femininas e por uma agente penitenciária pelo corredor do tribunal que é iluminado por lâmpadas fluorescentes com algumas levemente mais azuladas que as outras. Adriana acompanha Cristiane. Ao longe; Cristiane, policiais e Adriana entram por uma porta.

7 - INT/DIA - SALA ESCRITÓRIO DE DEOLINDA

Silêncio. Foto Preto e Branca num quadro de parede de moça vestida com beca de formatura. Esta moça é Deolinda Jovem. Abaixo da foto está o nome escrito: Deolinda de Jesus Santos. Ao fundo, Deolinda Senhora veste a beca. Som de toque na porta, Meirinho, 30 anos, branco, abre a porta e fica sob o batente.

MEIRINHO

Juíza Deolinda, estão todos prontos.

DEOLINDA SENHORA

Obrigada .

Deolinda Senhora agradece, Meirinho sai. Ela pega resma de papéis em pastas, as olha e sai. Fica imagem da foto de Deolinda Jovem. Som de passos de sapato em corredor reverberado.

8 - INT/DIA - CORREDOR DE FACULDADE 
Pés negros femininos com salto baixo caminham num corredor iluminado lateralmente pela luz do sol. Pés param. Deolinda Jovem, 23 anos, está vestida socialmente com blazer preto e calça preta, arruma algo em sua bolsa e pega um livro. Deolinda Jovem escreve um bilhete a frase "Preciso falar contigo" e o coloca sobressalente dentro do livro.

Deolinda Jovem caminha por um grande corredor de um edifício antigo com pé direito alto e janelas enormes. Burburinho de aula. Deolinda Jovem vai até uma porta e a abre. Emílio, 48 anos, pele morena clara, cabelos encaracolados negros e feições de pessoa com ascendência negra, está a frente da sala. Ele está vestido socialmente com terno sem gravata.

Deolinda Jovem entra. Ele palestra a pessoas jovens nesta sala. Emílio para o que falava quando Deolinda Jovem entra no recinto.

9 - INT/DIA - SALA DE FACULDADE

Numa Sala de Aula que se assemelha a um pequeno auditório, Deolinda Jovem adentra e entrega o livro que retirara de sua bolsa a Emílio. Eles se olham.

$$
\begin{aligned}
& \text { DEOLINDA JoVEM (fala baixo) } \\
& \text { Professor... obrigado... }
\end{aligned}
$$

Emílio retribui. Deolinda Jovem se assenta numa carteira. Emílio sorri para ela.

\author{
EMÍLIO \\ Coincidência, Deolinda. Estávamos \\ falando de você!
}

Deolinda Jovem se ajeita na sua carteira escolar e olha para Emílio. Ela está desconcertada.

EMÍLIO

Direito Penal Um, lembra? Sua defesa memorável acerca do caso Zulmira, lembra?

DEOLINDA JOVEM

Da empregada... que matou o patrão...

por amor...

EMÍLIO

Isso... Tudo bem, minha linda? 
Deolinda Jovem sorri de forma breve e acena positivamente com a cabeça. Emílio retira bilhete do livro entregue por Deolinda Jovem e o lê. Emílio fica sério, ele acena ligeira e positivamente para a moça, ele amassa o papel, jogando-o no lixo. Em seguida, Emílio olha para os alunos na Sala. Alunos na sala olham para Emílio e Deolinda Jovem.

\section{EMÍLIO}

(para todos) Pessoal, sei que a gente tá no Direito Penal Cinco, mas vamos voltar um pouco no Direito Penal Um! Os crimes passionais, aqueles movidos pela paixão, pelo desejo, são qualificados e tipificados nestes artigos...

Emílio aponta os números dos artigos na lousa.

$$
10 \text { - INT/DIA - TRIBUNAL }
$$

Pessoas se assentam na plateia do julgamento. Cristiane se assenta numa cadeira e policial feminina abre as algemas de Cristiane.

Num local onde há sete lugares, entram quatro mulheres (uma jovem negra, uma senhora negra, uma jovem senhora branca e uma jovem japonesa) e três homens (um rapaz negro, um senhor branco libanês e um senhor indígena).

Deolinda Senhora entra no tribunal, todos ficam de pé. Ela se assenta em sua cadeira de juíza e todos se assentam. Deolinda Senhora veste seus óculos.

$$
\text { DEOLINDA SENHORA }
$$

Bom dia a todos. Iniciaremos os
trabalhos neste tribunal com o caso
número Um seis zero nove desta
Comarca de Santana. A ré Cristiane
Aparecida dos Santos, 29 anos,
natural da cidade de São Paulo,
Bairro da Casa Verde, é acusada no
artigo 121 por duplo homicídio
qualificado de Alberto Oeiras
Magalhães, 38 anos e do menor Fábio
Luiz Oeiras Magalhães, 4 anos; filho
de Alberto...

Enquanto fala, Deolinda Senhora olha algumas vezes para Cristiane, que a olha. Entra som de samba enredo qualquer. 
11 - INT/NOITE - QUADRA DE ESCOLA DE SAMBA

Cristiane, vestida de fantasia de carnaval semelhante a um biquíni prateado com plumas e paetês, samba acompanhada de coro de bateria da Escola de Samba.

Alberto, 37 anos, branco, cabelos pretos, vestido elegantemente de maneira casual, olha Cristiane sambar. Enquanto samba é executado, NUNES, O apresentador da festa, fala.

NUNES (off)
E antes de chamar a nossa nova Rainha
da Bateria, vou anunciar aqui que o
Alberto Magalhães, dono da mineradora
ATX que patrocina nosso carnaval, é
quem vai entregar a faixa para a
nossa nova rainha da bateria, que é
uma deusa na terra...

Nunes, 40 anos, negro, ligeiramente gordo, anuncia ao microfone.

NUNES

A nossa nova Rainha da Bateria é... a nossa estonteante, linda e atrevida, a nossa mulata, Cristiane Bombom!

Cristiane se emociona e fica a frente de outras duas garotas negras que também estão fantasiadas com biquínis estilizados, plumas e paetês.

Alberto se aproxima e entrega a Cristiane uma faixa e uma coroa dourada. Cristiane dá dois beijos no rosto de Alberto. Eles se olham. Cristiane está emocionada e limpa suas lágrimas com cuidado na sua maquiagem. Som de Microfonia.

12 - INT/DIA - TRIBUNAL

Sai música de Samba. Deolinda Senhora bate dedo indicador no microfone e o ajusta. Ela olha para Cristiane, que a olha.

\section{DEOLINDA SENHORA}

Som... A promotoria, representada pela advogada Regina Bastos dos Santos, tem duas horas para arguição, por favor. Regina, tenha a palavra... 
Deolinda Senhora olha para REGINA, 32 anos, negra, vestida socialmente, levanta-se e caminha ao lado do Júri.

REGINA

Obrigado meritíssima! Inicio aqui minha arguição buscando entender o que leva uma mulher como Cristiane... negra e de origem pobre, empregada doméstica... mas com boas perspectivas em sua área artística, reconhecida no meio das escolas de samba e, de alguma forma, pela mídia paulistana... como ela planeja assassinar e assassina queimando vivos pessoas a quem ela demonstrava carinho que foram seu noivo e o filho dele. Criança esta que ela cuidava sendo babá da família! Uma linda criança que nada tinha feito contra a ela...

Regina olha para Deolinda Senhora, para Adriana e em seguida para Cristiane. Deolinda Senhora olha para Regina e em seguida para baixo, como se olhasse para o infinito.

\title{
13 - INT/DIA - BIBLIOTECA
}

Deolinda Jovem esta sentada a mesa de estudos. Ela anota algo num caderno e lê um livro. Ela veste roupa social vermelho vinho. Deolinda Jovem olha em volta, pessoas brancas estudam em respectivas suas mesas de estudo.

\section{EMÍLIO (off) \\ Deolinda!}

Emílio está em pé ao lado de Deolinda Jovem, ele se abaixa para beijar a boca da moça, mas Deolinda Jovem se desvia e Emílio beija a bochecha dela. Emílio estranha.

\author{
DEOLINDA JOVEM \\ Professor, eu precisava falar \\ contigo... \\ EMÍLIO \\ Eu sei, fofa... E eu tenho novidades! \\ Falei com minha esposa... Ela aceitou \\ a ideia do desquite!
}

Emílio mostra dedo anelar da mão esquerda sem anel, Deolinda Jovem o encara. 


\author{
DEOLINDA JOVEM \\ A ideia, mas e o fato?
}

Emílio suspira.

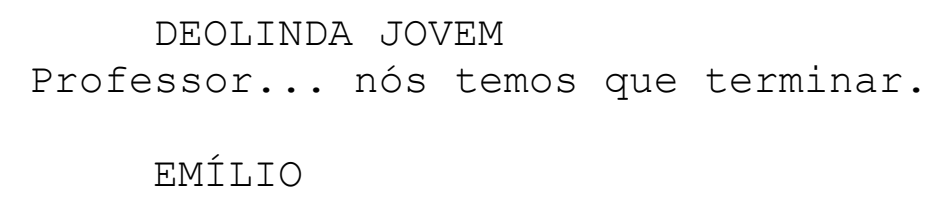

Não .

DEOLINDA JOVEM

Sim. Terminar sim! E você sabe o porque!

EMÍLIO

Eu só vou te pedir mais um tempinho,

Deolinda... Só mais um tempinho, eu

te prometo!

Emílio olha envolta e rouba um beijo de Deolinda Jovem. Ela se aborrece, mas sorri. Deolinda Jovem e Emílio se beijam. O Professor vira Deolinda Jovem de costas e a beija sussurrando na orelha.

\title{
EMÍLIO
}

Oh, Minha pretinha, fica calma...

Som de gemidos.

CRISTIANE (off)

Alberto, eu acho que a gente deveria se oficializar, sabe!

ALBERTO (off)

Não! De jeito nenhum!

14 - INT/DIA MANHÃ - QUARTO LUXUOSO

Boca de pessoa branca beija orelha de pessoa negra.

ALBERTO

Nem me separei ainda... E pra falar a verdade, eu não quero me casar nunca mais.

\section{CRISTIANE}

Não?

ALBERTO

Não! Tá muito bom assim! 
Alberto está deitado numa cama e abraçado as costas de Cristiane, que está também deitada na cama. Ele a beija na nuca e na orelha. Os dois estão nus, mas estão sob os lençóis.

\section{ALBERTO}

Posso te contar um segredo, Cris?

Cristiane se vira de frente para Alberto.

CRISTIANE (curiosa)

Hummm! Fala... vai...

\section{ALBERTO}

Quando a minha esposa te contratou pra trabalhar aqui em casa, eu pensei: Que morena mais linda a minha mulher tá me dando de presente!..

Cristiane sorri para Alberto.

CRISTIANE

Ah, fofo! Brigada! Mas você acha que a tua mulher... tua ex-mulher... me contratou de caso pensado?

\section{ALBERTO}

Será? Mas caso pensado ou não.. quando eu te vi, eu notei... assim... que você é a mais diferente das mulheres que conheci... e com quem fiquei junto depois...

\section{CRISTIANE}

Ah, é? Diferente como?

\section{ALBERTO}

Não dá pra explicar, Morena! Você sambando... Só te provando pra saber o gosto que você tem.

\section{CRISTIANE}

E que gosto sua Morena tem?

\section{ALBERTO}

Gosto... de pecado! Dos mais safados... E dos mais desejados também!

Alberto vira Cristiane de costas, junta os cabelos lisos 
de Cristiane e os segura com certa violência como um rabo de cavalo.

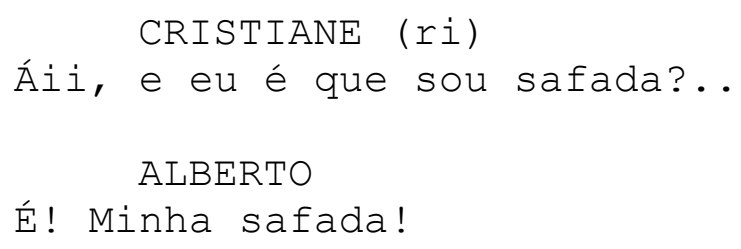

Som de choro de criança. Cristiane se desvencilha de Alberto.

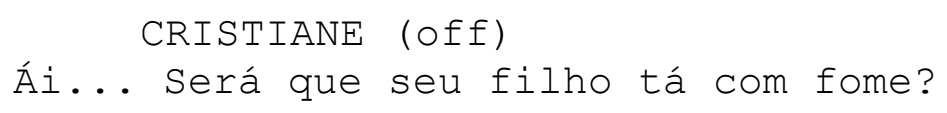

Cristiane sai da cama. Alberto se enfadonha. Portaretrato com fotos de Alberto ao lado de uma mulher branca e um bebê está sobre camiseira. Cristiane veste última peça da vestimenta de copeira e sai do quarto.

REGINA (off)

O que podemos tirar disso tudo?

15 - INT/DIA - TRIBUNAL

Regina, em pé e caminhando lentamente, argúi.

REGINA

Cristiane, a ré, se colocava como uma boa copeira, uma boa babá... e ao mesmo tempo, com seus encantos; a mulata do carnaval paulista seduziu veementemente Alberto. Era sua oportunidade para mudar de vida. Não podia perder a chance. Chance esta que não deu para a vítima, nem para o filho dele... de quatro anos! (enérgica)... Por um motivo fútil. Por um motivo torpe... que somente por esse olhar de criminosa já a condena...

Adriana se levanta, encara Regina e olha para Deolinda Senhora.

ADRIANA

Protesto meritíssima! Nosso código não prevê que a feição, o olhar ou o porte físico da acusada sejam qualidades, agravantes ou mesmo determinantes para a verdade dos 
fatos. Não seguimos teorias

lombrosianas.

Deolinda Senhora olha para Cristiane.

DEOLINDA SENHORA

Protesto concedido. A Promotora se atenha aos fatos neste tribunal.

Regina olha para Deolinda Senhora e em seguida olha para Adriana, que a olha e depois, vê o júri. Deolinda Senhora olha para Adriana e em seguida para Cristiane, que a olha.

\section{6 - INT/NOITE - SALA/ESCRITÓRIO DE EMÍLIO}

Numa sala com mesa, biblioteca e um grande sofá de couro, Deolinda Jovem, triste, veste seu sutiã. Emílio está em pé e veste suas roupas. Deolinda Jovem o olha e em seguida para retratos de Emílio ao lado de uma mulher branca, um rapaz e um adolescente.

Trata-se de Helena, branca, 42 anos, magra e Gilberto, 16 anos, branco, cabelos negros. Em alguns retratos, Emílio está abraçado a Helena, em outras, eles se beijam. Emílio pega um livro de sua valise e o joga um livro sobre a cama. Ele tem pressa.

\section{EMÍLIO \\ Toma... Trouxe da Itália. Tá em latim.}

Deolinda Jovem o olha e veste sua roupa. Emílio termina de se vestir e caminha em direção a porta.

DEOLINDA JOVEM

Era assim que você tratava sua exesposa?

\section{EMÍLIO}

Como assim?

DEOLINDA JOVEM

Era assim que você tratava sua exesposa?!

Emílio e Deolinda Jovem se encaram. Ele se aborrece.

DEOLINDA JOVEM
Eu tô falando de igualdade,
professor!




\section{EMÍLIO}

Que igualdade?! Até parece que não assiste minhas aulas...

Emílio tenta abraçar Deolinda Jovem, que se esquiva, ela está emocionada. Emílio, bravo, desiste.

\section{EMÍLIO}

Fica com o livro, você precisa mais

dele do que eu... Agora é melhor

sair, o pessoal pode perceber.

Deolinda Jovem sai da sala com lágrimas nos olhos.

17 - INT/DIA - SALA DE ESTAR DE CASA LUXUOSA

Mão negra passa pano em porta retratos nos quais vemos Alberto; LíGIA, 37 anos, branca e Fábio, 3 anos, branco, cabelos claros. Um dos porta retratos tem foto com estas três pessoas juntas. Cristiane pega este porta-retrato e o contempla.

Fábio, sentado, brinca com alguns brinquedos no chão. Cristiane olha para Fábio e se aproxima dele. Ela ajoelha no chão e olha para Fábio, que a olha. Fábio oferece um brinquedo a ela. Cristiane sorri. Cristiane brinca com Fábio, que fica de braços abertos e a abraça. Cristiane o pega no colo. Som de campainha.

\section{CRISTIANE}

Quer ser o meu filhinho, menino fofo?

Quer ser o meu filhinho, hein?

Cristiane leva Fábio no colo, ela vai até interfone e o atende.

CRISTIANE

Pois não... (enfadonha-se) Momento!

Cristiane aperta botão no interfone e sai.

18 - EXT/DIA - TERRAÇO DE CASA DE LUXO

Cristiane caminha no terraço. Lígia adentra o portão e olha Cristiane segurar Fábio no colo. Lígia se aproxima e pega Fábio no colo.

\section{LÍGIA}

Escuta aqui! A mãe, ainda! Ainda sou eu, tá sabendo? 


\section{CRISTIANE}

Mãe é quem cuida, ô branquela!.. se o

Fabinho precisasse de você...

LÍGIA

Você pensa que faz parte, né?

\section{CRISTIANE}

Não penso. Eu faço! E sou mais competente que você!

\section{LÍGIA}

Garota, você sempre foi um escape pros hormônios do Alberto! Você é que nem uma boneca... inflável! Por isso eu te contratei! E você fez muito bem esse papel! Mas você sabe muito bem que nunca será além disso, ô globeleza!

Lígia sai. Cristiane encara Lígia.

\section{9 - INT/NOITE - SALA DE JANTAR}

Deolinda Jovem está triste e sentada a mesa. Há travessas com comidas vistosas e coloridas que aparentam ser gostosas. Mão feminina negra abre uma travessa tampada de arroz. O vapor sobe. Deolinda Jovem está cabisbaixa.

\section{LINDALVA (off)}

Filha, se anima! É difícil, mas homem

é assim... Zé, Lourdes, vem jantar!

Lindalva, 44 anos, negra, vestida com certa elegância, retira arroz com escumadeira e coloca num prato. Lourdes, 14 anos, negra, entra na cozinha.

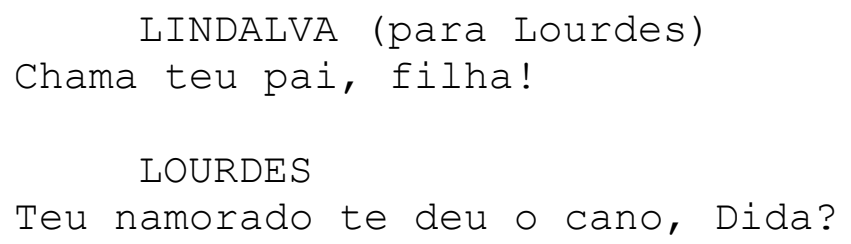

Deolinda Jovem olha seriamente para Lourdes. José, 48 anos, negro, vestido com calça social e camisa, entra na cozinha e pega um prato.

JOSÉ

Dida, esse negócio de aluna namorar professor não dá certo, filha! Por 
que você não namora alguém da sua idade, da sua turma?

DEOLINDA JOVEM

Porque ninguém naquela faculdade demonstrou interesse por mim. Só meu professor.

LINDALVA

Ele é bem mais velho que você filha... e ele ainda é solteiro?

DEOLINDA JOVEM

Não mãe, ele se desquitou da mulher dele... há dois meses.

José, Lindalva e Lourdes sentam a mesa.

LOURDES

Mas você tá quase um ano com ele!

Deolinda, aborrecida, olha para Lourdes.

JOSÉ (bravo)

Dida... Deolinda! Você tava namorando todo esse tempo com um homem casado, filha?

Deolinda Jovem, brava, olha para Lourdes e sai da mesa.

JOSÉ

Deolinda! Volta aqui, seu pai lhe fez uma pergunta! Deolinda!

ADRIANA (off)

Eu não tenho dúvidas em dizer que Cristiane é a verdadeira vítima dos acontecimentos!

20 - INT/DIA - TRIBUNAL

Plateia protesta. Deolinda Senhora intervém.

DEOLINDA SENHORA

Silêncio no tribunal, por favor!

Adriana argúi.

ADRIANA

Obrigado, Meritíssima! Cristiane é a vítima! Sim! Passou a vida como 
vítima! Esta mulher, de origem pobre, de família desestruturada teve oportunidades somente naquelas em que seu esforço físico como doméstica ou sua beleza física como mulata do carnaval foram válidas. Numa sociedade em que há cento e vinte três anos aboliu a escravatura, Cristiane foi comprada (gesticula aspas) pela sua patroa para ser a doméstica e também para ser uma amante controlável de Alberto! Ela é vítima!

21 - INT/DIA - SALA DE FACULDADE

Deolinda Jovem se levanta de sua carteira escolar.

DEOLINDA JOVEM

Vítima? De novo esse papo, Cacete!

JORGE, 22 anos, branco, ligeiramente gordo, retruca.

JORGE (contrariado)

Professor, esse linguajar da

colega... por favor...

Emílio, um pouco tenso, intervém.

EMÍLIO

Deolinda, por favor, mantenha a compostura.

DEOLINDA JOVEM

Ainda não estamos no tribunal, então não precisamos manter as aparências!

Deolinda Jovem se recompõe.

DEOLINDA JOVEM

Entenda a síntese do que sustento! No Caso Zulmira, o fato dela ser conhecida somente como a empregada que matou o patrão e o fato do clima dicotômico criado naquele tribunal de júri, não impediram que tanto as arguições da promotoria quanto da defesa levantassem questionamentos dialéticos a cerca dos fatos... 


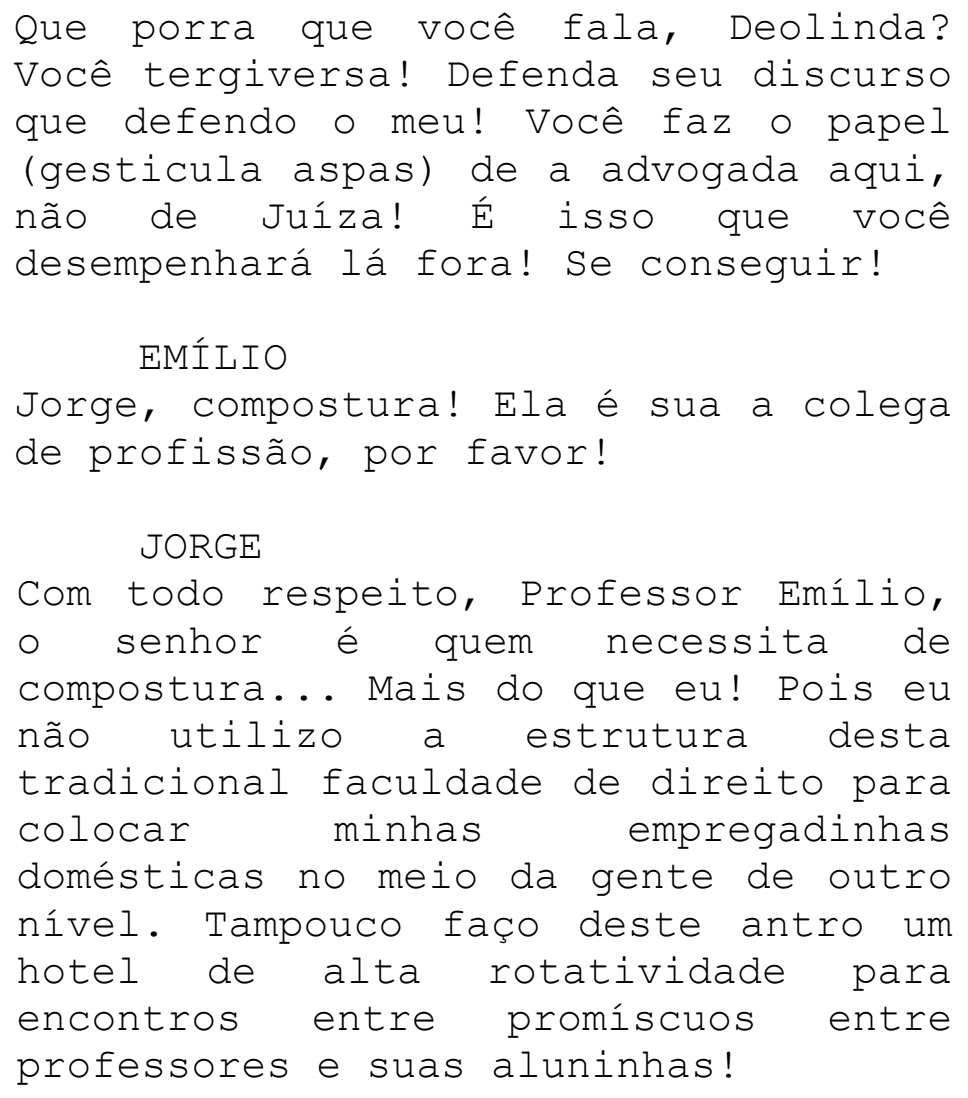

Jorge olha para Deolinda Jovem. Emílio fica tenso. Alunos os olham. Deolinda Jovem encara Jorge.

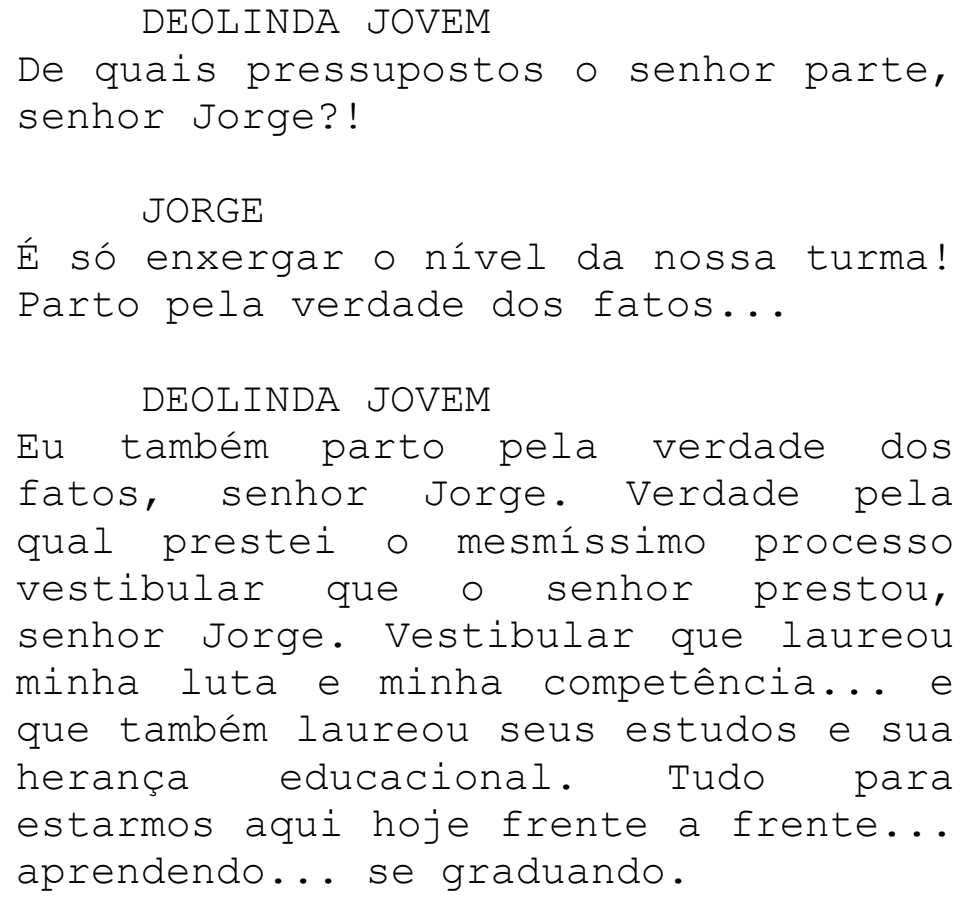

Emílio guarda seus livros numa valise. Deolinda Jovem e Jorge se encaram. 


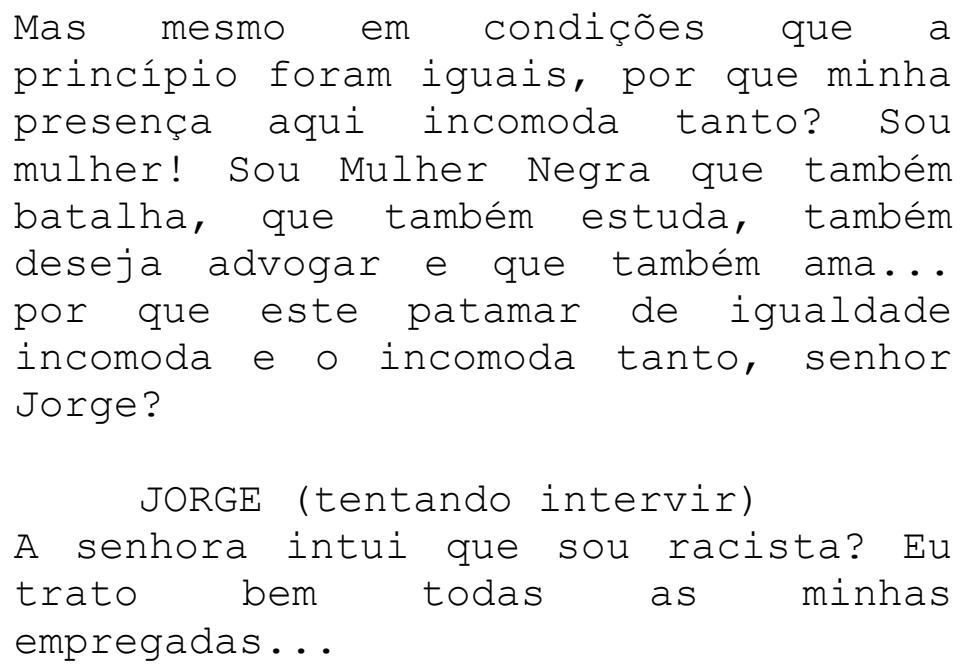

Emílio guarda suas coisas e sai da sala. Deolinda Jovem não percebe.

\section{DEOLINDA JOVEM}

Eu não sou sua empregada. (olha para alunos na sala) Nem a operadora da fotocópia, nem a funcionária da secretaria acadêmica, nem a mulata de bateria do Centro Acadêmico... tampouco sou a pobre preta ressentida... tampouco a filha da faxineira desta faculdade... ou outra atividade laboral pela qual muitos de vocês me confundiram ao longo da minha presença nesta faculdade... ao longo desta graduação na são Francisco. Com toda a humanidade que me tange e o direito de amar e de sentir amada, a única pessoa que enxergou aquilo que exerço aqui, como aluna...

Lugar que Emílio ocupava está ausente.

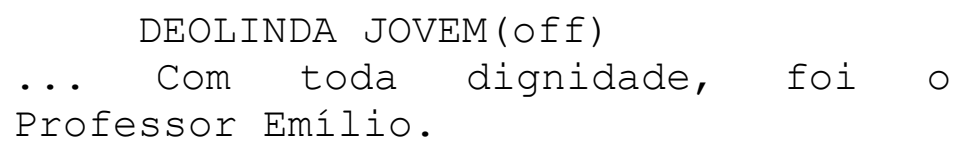

Passos largos de pés negros femininos. Deolinda Jovem caminha pelo corredor da faculdade. Ela chora e carrega sua bolsa nas costas. Deolinda Jovem vai a porta de uma sala e vacila ao estender a mão para abrir a porta. Deolinda Jovem abre a porta. 
23 - EXT/DIA - QUINTAL/TERREIRO DE CASA LUXUOSA

Nunes toca cavaquinho acompanhado de outros músicos (alguns negros, outros brancos) que tocam tantan, tamborins, Violão de Sete Cordas. Senhoras e senhores, vestidos a caráter como velha guarda de escola de samba, cantam.

Pessoas vestidas de maneira casual, mas elegante conversam entre si. Há poucas pessoas próximas a roda de samba formada. Alberto, vestido de bermuda e camisa pólo, bebe champagne numa taça.

Cristiane, vestida como copeira, serve champagne àlgumas pessoas na festa. Selma, negra, 70 anos é uma das cantoras da velha guarda; ela olha para Nunes demonstrando estar chateada.

\section{SELMA \\ $\hat{E}$ Nunes! Essa papagaiada toda faz parte do Patrocínio?}

Nunes responde positivamente, mas contrariado. Alberto acena para roda de samba pedindo um tempo.

\section{ALBERTO}

Pessoal! A ATX, empresa de meu papai, patrocina pela primeira vez a Rosas

no nosso próximo carnaval... e

patrocina este belo encontro que

estamos tendo aqui!

Alberto olha para Cristiane e para as pessoas da escola de samba que estão na roda de samba.

\section{ALBERTO}

Tenho aprendido bastante ao pisar

barro e sujar os meus pés de lama

para encontrar pessoas como o Nunes,

a Dona Selma, o Nogueira...

Pessoas aplaudem. GIULIANNA, 23 anos, loira, corpo esguio, carrega Fábio no colo, aproxima-se de Alberto.

\section{ALBERTO}

Eu, inclusive, sou um homem sortudo!

Sortudo porque tenho em minha casa a

Cristiane...

Alberto gesticula a Cristiane para ela se aproximar dele. 
ALBERTO

Vem, Cris! A Cris é minha empregada, é baba do meu filho e mostra no carnaval sua beleza estonteante como a Mulata Rainha da Rosas de Ouro!

Pessoas aplaudem. Alguns músicos da roda de samba estão sérios.

\section{ALBERTO}

Cristiane, eu queria que você desse uma canja pros nossos convidados daquilo que você sabe fazer aqui pra gente!

Cristiane sorri, ela se aproxima da roda de samba, pega um violão. Ela olha para selma e começa a tocar uma música em ritmo de partido alto no violão. Alberto olha com estranhamento, mas sorri.

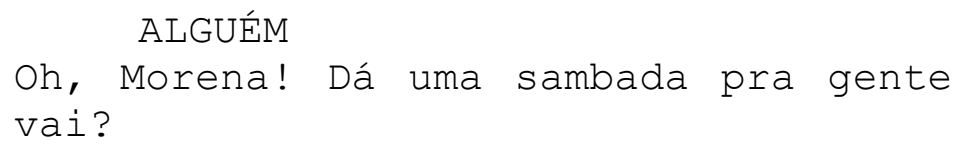

Cristiane sorri. Samba continua. Giulianna e beija Alberto na boca. Cristiane os olha. Alberto e Giulianna percebem fotógrafo e repete pose de beijo para fotógrafo registrar o momento. Cristiane olha para Alberto, samba é cantado e ela devolve o violão a um dos músicos. Cristiane encara Alberto, que a olha e puxa aplausos para a garota. Pessoas a aplaudem. Cristiane agradece ligeiramente.

\section{ALBERTO}

Pega uns canapés pra gente, Cris?

Fotógrafo tira mais fotos do casal. Cristiane os encara. Flash de foto.

24 - INT/DIA - SALA DE PROFESSOR

Porta se abre sutilmente. Carinhosamente, Emílio abraça e beija testa de Helena, a mesma mulher que Deolinda viu nas fotos presentes na sala de Emílio.

25 - INT/DIA - CORREDOR DA FACULDADE

Deolinda Jovem olha para Emílio e Helena...

26 - INT/DIA - SALA DE PROFESSOR 
Helena olha para o lado onde Deolinda Jovem está, fato que chama atenção de Emílio, que vê a moça. O professor se assusta.

27 - INT/DIA - CORREDOR DA FACULDADE

Deolinda Jovem acena pedindo desculpas.

HELENA (off)

Espera! Você que é a Deolinda?

28 - INT/DIA - SALA DE PROFESSOR

Helena sorri.

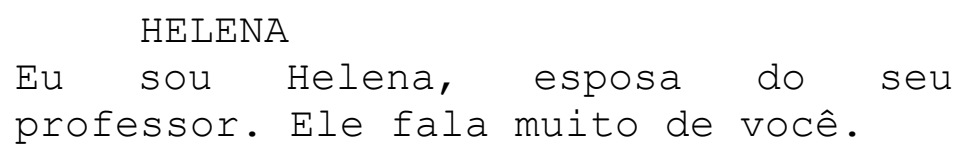

Helena estende a mão e se aproxima de Deolinda Jovem

29 - INT/DIA - CORREDOR DA FACULDADE

Helena cumprimenta Deolinda Jovem, que está séria.

30 - INT/DIA - TRIBUNAL

Deolinda Senhora está sentada. Bate o martelo e se levanta.

DEOLINDA

O Tribunal entra em recesso de trinta

minutos.

Deolinda Senhora sai. Público conversa entre si.

31 - INT/DIA - CORREDOR DO TRIBUNAL

Deolinda Senhora caminha no corredor do tribunal. Ela tenta abrir porta com sinalização de banheiro feminino, mas há placa escrita a mão com a frase "Fora de Serviço". Deolinda Senhora sai e caminha ao longe. Som de descarga em privada.

32 - INT/DIA - BANHEIRO

Deolinda Senhora sai do box do banheiro e caminha em direção ao lavatório, mas percebe que Cristiane lava suas mãos em outra pia do lavatório acompanhada de Policial Militar Judiciária Feminina. 


\author{
POLICIAL FEMININA \\ Perdão, meritíssima... \\ DEOLINDA SENHORA \\ Tudo bem...
}

Deolinda Senhora lava suas mãos e Cristiane lava seu rosto. Cristiane retira papel toalha e olha para Deolinda Senhora, que agora lava seu rosto. Cristiane enxuga lentamente seu rosto com toalha de papel enquanto olha atentamente para Deolinda Senhora, que levanta seu rosto da pia e olha para Cristiane.

Cristiane sorri levemente para Deolinda Senhora e cumprimenta com um gesto balançando a cabeça. Deolinda Senhora retribui e Cristiane sai do banheiro acompanhada da Policial Militar Judiciária Feminina.

Deolinda Senhora pega papel toalha e começa a enxugar seu rosto. A Juíza se encara no espelho.

33 - INT/NOITE - QUARTO DE DEOLINDA JOVEM

Mãos negras femininas abotoam tecido preto. Uma das casas do tecido não tem botão. Deolinda Jovem está em frente ao espelho. Ela se olha, coloca uma pequena bolsa com grande alça, tenta ajeitá-la com sua beca e sai.

34 - INT/DIA - ESCRITÓRIO

Cristiane olha para algo num armário. Ela pega ao lado um lençol branco e embrulha este algo com este pano.

35 - INT/NOITE - COPA DA CASA DE DEOLINDA

José, Lindalva e Lourdes assistem a programa televisivo em televisor preto e branco. Deolinda Jovem os olha a distância.

36 - INT/DIA - CORREDOR DE CASA LUXUOSA

Cristiane caminha pelo corredor da casa. Ela está sozinha.

37 - INT/NOITE - QUARTO DOS PAIS DE DEOLINDA JOVEM.

Mão negra abre gaveta. Encontra rolinho de linha. Mão negra continua a procurar em outra gaveta mais a baixo. Retira-se alguns panos, alguns papéis e encontra uma caixa. Esta mão abre esta caixa e pega um Revólver Calibre 32. Deolinda Jovem olha para a arma nas suas 
mãos .

38 - EXT/DIA - QUINTAL DA CASA DE LUXO

Quatro Garrafas enfileiradas estouram uma seguida da outra. Cristiane tem uma espingarda nas mãos e mira na última garrafa. Garrafa estoura. Cristiane sorri.

39 - INT/DIA - TRIBUNAL

Deolinda Senhora está de pé ao lado de sua cadeira de juíza. Cristiane se senta na cadeira destinada aos réus.

DEOLINDA SENHORA

Estamos retomando os trabalhos...

Cristiane levanta sua mão. Algumas pessoas ainda se sentam na plateia logo após Deolinda se sentar.

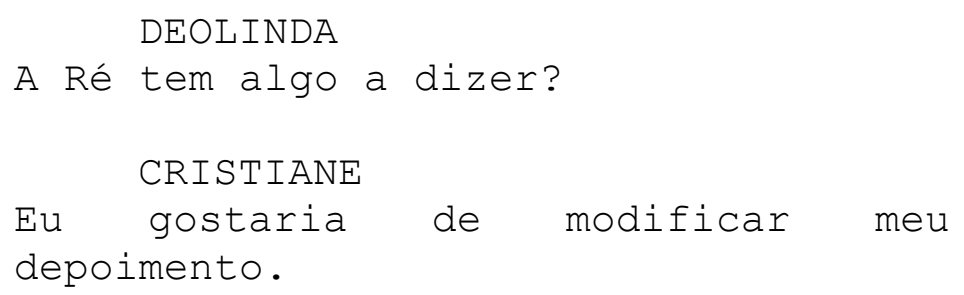

Deolinda Senhora olha para Cristiane, que a olha. Som de Aplausos.

MESTRE DE CERIMÔNIA (off)

A formanda Deolinda de Jesus Santos!

40 - INT/NOITE - AUDITÓRIO

Deolinda Jovem, vestida de beca e capelo, caminha no auditório. Ela olha para mesa de docentes, um deles é Emílio, que olha Deolinda Jovem em relances.

41 - INT/NOITE - PLATÉIA DE AUDItÓRIO

Helena, esposa de Emílio e o adolescente Gilberto estão sentados na plateia e olham para Deolinda Jovem.

42 - INT/NOITE - AUDITÓRIO

Deolinda Jovem recebe um canudo de formatura de um professor. Ela agradece, cumprimenta-o e se vira para a plateia. Imagem em Câmera lenta: Deolinda Jovem olha para...

43 - INT/NOITE - PLATÉIA DE AUDitóRIO 
...José, vestido de terno; Lindalva, vestida socialmente e Lourdes, também vestida elegantemente, aplaudem.

\title{
44 - INT/NOITE - AUDITÓRIO
}

Deolinda Jovem está chorando. Ela cumprimenta outros professores, mas olha atentamente para Emílio. Quando chega a vez de Deolinda Jovem cumprimentá-lo, ela leva sua mão para dentro de sua pequena bolsa marrom. Som de arma sendo engatilhada.

45 - INT/NOITE e EXT/NOITE - QUINTAL DE CASA LUXUOSA

Alberto carrega Fábio no colo, ele o coloca no banco traseiro de uma Van luxuosa. Alberto fecha a porta traseira e se vira. Ele olha para alguém. Na varanda próxima ao quintal, Cristiane olha para Alberto, ela tem o rosto molhado como quem chorou. Cristiane está transtornada.

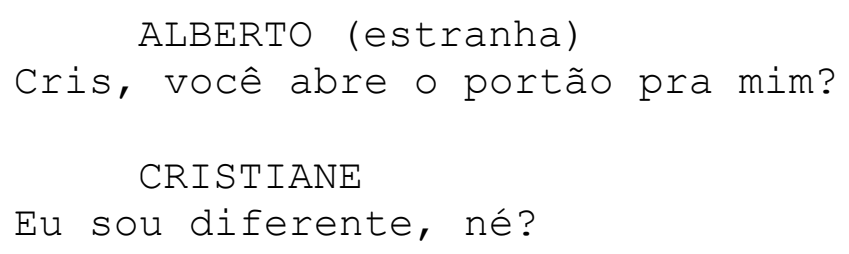

\section{ALBERTO}

Ô Cris! Aquela moça lá é pra manter a minha imagem!

\section{CRISTIANE}

Qual imagem? Aquela em que não posso ficar ao lado da sua?

Alberto sorri.

\author{
ALBERTO \\ Oh, minha morena. Não é isso... \\ CRISTIANE \\ Ah, não é isso? Negra pra estar em
}


sua casa, mas mulata pra estar em sua

cama... não é isso?

Cristiane pega uma espingarda. Alberto se assusta. Cristiane mira em Alberto.

\section{ALBERTO}

Para Cris! Eu te amo!

\section{CRISTIANE}

Ama? Eu também!

Cristiane atira para cima. Alberto entra rapidamente no carro dá partida e sai, chiado de pneus. Cristiane atira três vezes, som de batida de carro e buzina; na quarta vez, a moça é iluminada por uma explosão intensa. Cristiane cai.

46 - INT/DIA - TRIBUNAL

Deolinda Senhora olha para Cristiane.

DEOLINDA SENHORA

Nos autos do instituto de Criminalística, consta que um dos quatro tiros acertou o tanque...

\section{CRISTIANE}

Eu mirei no carro do Alberto... Imaginava que tinha blindagem... Eu não sabia que 0 Fabinho tava no carro.

Cristiane se emociona e olha Deolinda.

\section{7 - INT/NOITE - AUDITÓRIO}

Imagem sem câmera lenta. Deolinda Jovem hesita, mas retira um bilhete e o entrega a Emílio. Eles se cumprimentam apenas com as mãos. Deolinda cumprimenta outros professores e professoras abraçando-os. Emílio lê o papel entregue.

\section{CRISTIANE}

Eu fui condenada várias vezes...

48 - INT/DIA - TRIBUNAL

Cristiane depõe. 
Nos cinco anos que fiquei na penitenciária... eu sinto que a sociedade encontrou uma vilã! Eu sou uma figura inquestionável pra isso! As presas lá do meu pavilhão encontraram alguém... ou algo... pra dar porrada, pra extravasar a violência do dia-a-dia, a violência da vida...

Deolinda Senhora olha para Cristiane.

CRISTIANE (off)

$\mathrm{Na}$ verdade, meu corpo serviu pra muita gente extravasar muita coisa... desejos... poderes...

Cristiane depõe.

\section{CRISTIANE}

Lá na mansão do Alberto, eu não sabia até onde era meu trabalho, eu não sabia até onde eram meus sentimentos. Imaginei no olhar e nos convites do Alberto uma coisa maior do que simplesmente eu acreditava que era.

Regina olha Cristiane, assim como Adriana.

Não era uma oportunidade pra mim, sabe? Nem oportunismo...

Cristiane depõe.

\section{CRISTIANE}

Mas um reconhecimento... como mulher... como mulher possível... uma mulher que eu nunca fui... muito além de mulata do carnaval que eu era, muito além de tudo... Mas encontrei algo em que nunca iria pertencer...

49 - INT/NOITE - AUDITÓRIO

Deolinda Jovem vê Emílio, Helena e Gilberto caminharem no sentido da porta de saída. José, Lindalva e Lourdes se aproximam e abraçam Deolinda Jovem. Deolinda Jovem chora e olha em direção ao espectador. 
Apesar do todo, do tempo, das porradas desses quatro anos lá, reclusa... Estes anos foram de consciência...

50 - INT/DIA - TRIBUNAL

Pessoas do Júri e da Plateia olham para Cristiane. A Moça olha para o espectador.

\section{CRISTIANE}

Consciência de que o Alberto não era - alvo dos meus disparos. Eu não queria matar o Alberto... muito menos - Fabinho... Acho que, no fundo, eu quis matar o que ele significava... e o que eu signifiquei naquilo tudo... esse tempo todo...

Sobe trilha sonora. Cristiane encara o espectador.

51 - INT/DIA - SALA ESCRITÓRIO DE DEOLINDA

Foto Preto e Branca de Deolinda Jovem vestida de beca e capelo. Toga está pendurada em mancebo. Ao fundo, Deolinda está sentada. Mais próxima, Deolinda começa a chorar. Ela olha para cima como que quer parar de chorar e sorri.

52 - EXT/DIA - ENTRADA DE CARROS DO TRIBUNAL

Três viaturas policiais saem do estacionamento do Tribunal. Jornalistas tiram fotos.

53 - INT/DIA - VIATURA

Cristiane está sentada na viatura. Ela olha para a paisagem da janela. Ela sorri ligeiramente e tem lágrimas nos olhos. Trilha sonora percorre créditos.

TELA PRETA

CRÉDITOS FINAIS 


\section{Ensaio: Demolir para Construir}

\subsection{Metáforas com a Construção Civil. Demolindo para construir.}

No ramo da Construção Civil, algumas vezes para se construir algo, é necessário demolir aquilo que está no lugar. Se a edificação não pode ser restaurada e se ela apresenta riscos à utilização daquele espaço, a opção muitas vezes se dá pela demolição. Este serviço pode ser realizado em diversas formas: Implosão com dinamite e remoção da massa demolida para um aterro qualquer; serviço manual-operário através de marretas e talhadeiras; ou por máquinas como Bola de Demolição, Retro-escavadeira, Trator-Britadeira e Bulldozer (Trator de Terraplanagem). $\mathrm{O}$ processo para se demolir algo deve ser realizado com muito cuidado, seguindo um planejamento bem fundamentado diante da construção a ser desmontada. Para tanto, a demolição tem de ser realizada passo a passo e com parcimônia.

Passando do concreto para o simbólico, este texto de mestrado percorre um caminho semelhante. Para construir os significados audiovisuais que proponho e que contemplam a pessoa negra na sua complexidade sendo cidadã e cidadão pertencentes à sociedade brasileira, primeiramente é necessário realizar uma espécie de serviço de demolição simbólica. No caso, metafóricamente, o Edifício a ser demolido é algo que denomino como a CASA GRANDE AUDIOVISUAL. Neste lugar, é comum que a representação do negro e do branco habitem lugares fixos ou pré-dispostos a neles se herdar e permanecer. $O$ negro pode ser representado 
positiva ou negativamente, mas sabemos que na PERIFERIA desta CASA GRANDE há sempre uma SENZALA para o negro representar seu ato de habitar nela. Sabemos os lugares, por mais carinho que possamos ter nessa relação e por mais complacência do colonizador branco tenha em relação ao negro neste lugar ${ }^{1}$.

Muitos dos cidadãos da Periferia desta Casa Grande, a Senzala no caso, desejam entender e viver estes dois espaços de maneira diferente. A resistência se faz. Senzala se torna Quilombo. E esta resistência é quem dá força para reconhecer que estes e estas quilombolas audiovisuais também tem o direito de circular no espaço desta Casa Grande Audiovisual. Mas para eles e elas do quilombo, o espaço da Casa Grande, simbólica, que denota poder, não faz mais sentido. Tanta força na sua proteção esconderam rachaduras profundas. Algumas pessoas desta Casa Grande relutam em sair, alguns querem reformar, outros querem permanecer mesmo se ela cair; alguns querem demolir para construir uma igual, pagando pra isto salário aos quilombolas que a reconstruirão; já outros querem construir algo diferente num espaço novo. Muitos do Quilombo enxergam na demolição desta Casa Grande, um ato capaz de criar/entender um outro espaço possível. Nesta visão, os(as) quilombolas compreendem que também têm o direito de construir representações neste espaço e não somente na senzala.

Mas esta construção não pretende ser única, como acontecia na Casa Grande anterior. Nesta nova construção, entende-se que o espaço para se construir

1 Casa Grande e Senzala eram construções rurais fundiárias das épocas colonial e imperial do Brasil. Respectivamente, elas delimitavam os espaços habitados pelo colonizador português e os escravos negros. Em 1933, o antropólogo Gilberto Freyre escreveu sua obra denominada "Casa Grande e Senzala", nela Gilberto afirma que a própria estrutura arquitetônica do destes espaços refletem a estrutura social e política que formou o Brasil. Gilberto Freyre destaca o patriarcalismo como exercício de poder no qual o dono das terras era também dono de pessoas (escravos) e de sua família. 
é muito grande, quase ou sendo um antigo latifúndio audiovisual. Dá para habitar uma vizinhança, quem sabe uma aldeia ou um quilombo. Cada um, nesse bairro consegue circular e encontrar seus vizinhos com toda a dignidade que suas histórias de vida envoltas em identidade, ancestralidade e cultura lhe conferem humanidade. Em pessoa e em comunidade. Neste processo, não pretendo descartar o entulho da demolição, a proposta sim é reciclá-lo.

Como explosivos de tri-nitro-tolueno $(\mathrm{TNT})^{2}$, retro-escavadeiras, bulldozer, e britadeiras, eu utilizo alguns significados das palavras "aristocracia", "aristocrática", "aristocrata", "elitismo", "elitista" e as palavras "branquitude" e/ou "branquidade”. Eu as utilizarei não como fato dado, mas como relação que se faz e se apreende, por exemplo, num ambiente universitário. Preciso, para tanto, conceituá-las e contextualizar a forma com que eu as irei utilizar. Elas me auxiliarão nas provocações necessárias para dissertar sobre a relação em ser negro na universidade e como isso se relaciona ao retrato da periferia. No início desta demolição, eu caminho por um senso prático e comum sobre os significados destas palavras. Utilizo para isto, o auxílio de dicionário e de enciclopédia. Desta forma, segundo o dicionário "Michaelis"3, o termo "Aristocracia" significa:

1. Sociedade politicamente organizada, cujo controle estatal é privativo de uma camada social privilegiada.

2. A classe ${ }^{4}$ nobre, os fidalgos.

2 Tri-nitro-tolueno ou 2-metil-1,3,5-trinitrobenzeno, é um explosivo amplamente utilizado em demolições e pedreiras. Sua representação é: $\mathrm{C}_{7} \mathrm{H}_{5} \mathrm{~N}_{3} \mathrm{O}_{6}$

3 A Edição 2010 do Dicionário Michaelis disponibiliza serviço via internet para consultas. www.michaelis.com.br.

4 Os termos "Classe" e "Classe Social" são utilizados nesta dissertação num sentido retórico. 
3. Classe social superior pelo saber e merecimento real.

Podemos encontrar o termo "Aristocracia" em diversas enciclopédias, no caso, a enciclopédia britânica tem uma definição enxuta e direta. Nela, a palavra "Aristocracia" tem origem grega e ela é composta em duas palavras deste idioma: aristós, significa melhores e krátos, significa poder. Logo, literalmente "Aristocracia" significa "Poder dos Melhores" e, segundo a Enciclopédia Britânica, este termo remete a uma forma de governo na qual o poder político é dominado por um grupo que exerce os valores daquilo que o conceito do "melhor" signifique na sociedade ${ }^{5}$. Pessoas desse grupo são da classe dominante, como latifundiários, militares, sacerdotes, etc. Para uso em contextos históricos de Idade Média, o termo "Aristocracia", além de significar uma forma de poder em si, indica também um estamento de nobreza clerical que se sobressaía pelos altos postos militares e por privilégios transmitidos hereditariamente. Atualmente o termo "Aristocracia" é sinônimo de alta sociedade.

Ainda num sentido enciclopédico, para designar o conceito "Alta Sociedade", temos também o adjetivo "Elite" e palavras derivadas dela como "Elitização" e "Elitismo". No dicionário "Michaelis", o termo "Elite" vem do idioma francês (Élite) e significa nata da sociedade, de um grupo, de uma classe. "Elite" pode ser uma referência genérica a grupos posicionados em locais hierárquicos de diferentes instituições públicas, partidos ou organizações de classe; ou seja, pode ser entendido simplesmente como aqueles que têm capacidade de tomar decisões políticas ou econômicas. "Elite" pode ainda designar aquelas pessoas ou grupos 
capazes de formar e difundir opiniões que servem como referência para os demais membros da sociedade; neste caso, "Elite" seria um sinônimo tanto para liderança quanto para formadores de opinião. "Elite" também pode significar genericamente um grupo localizado em uma camada hierárquica superior em uma dada estratificação social ou pode ser um grupo minoritário que exerça uma dominação política sobre a maioria dentro de um sistema de poder democrático.

Desta forma; "Elitismo", termo oriundo de "Elite", significa um o sistema embasado no favorecimento de minorias, normalmente de membros da aristocracia. O Elitismo pode se apresentar como diversas formas de pensamento que favorecem as mais prósperas camadas sociais. Segundo Ted C. Lewellen, na sua obra "Political Anthropology - An Introduction"6, o termo "Elitismo" provém não da prosperidade ou de funções sociais específicas, mas de um vasto e complexo corpo de símbolos, inclusive de condutas, estilos de vestimenta, sotaque, atividades recreativas, rituais, cerimoniais, entre outros (Lewellen, 2003, p. 48). Habilidades e aptidões que podem ser ensinadas conscientemente, enquanto o grande vulto de símbolos que forma o verdadeiro elitismo se forma inconscientemente.

Passando por este conceito no qual o elitismo pode ser exercido inconscientemente, trago outra palavra: "Branquitude". Primeiramente, branquitude é uma tradução do conceito "Whiteness", utilizado frequentemente nos estudos de relações raciais nos Estados Unidos. Maria Aparecida Silva Bento ${ }^{7}$, pesquisadora

6 Ver "Political Anthropology - An Introduction", Ted C. Lewellen, p.48. Editora: Greenwood. 2003.

7 Maria Aparecida Bento é doutora em Psicologia Social pela USP e é fundadora do Centro de Estudos das Relações do Trabalho e da Desigualdade (CEERT). Em 1998, Maria Aparecida realizou sua publicou livro (pela Editora Ática) oriundo de sua tese de Doutorado "Pactos Narcísicos no racismo: branquitude e poder nas organizações empresariais e no 
brasileira sobre relações raciais no ambiente de trabalho traz uma interpretação interessante disto. Ela desenvolve o termo "Branquitude" (também as vezes considerado como sinônimo de "Branquidade" aqui no Brasil) como significado de um comportamento social realizado a partir de uma situação estruturada de poder baseada numa racialidade neutra, não nomeada, mas sustentada pelos privilégios sociais continuamente experimentados; no caso brasileiro, daquilo que significa branco. Apesar de branquidade e branquitude serem algumas vezes considerados sinônimos, Maria Aparecida Silva Bento distingue uma diferença entre os dois. Para ela, branquidade está relacionada ao exercício e/ou defesa da branquitude; ou seja branquitude seria o conjunto de ideias e branquidade, o exercício delas. Em relação ao que significa esta branquitude brasileira; Edith $\mathrm{Piza}^{8}$ (também estudiosa das relações raciais brasileiras pelo ponto de vista do que significa branco em nossa sociedade) partiu de trabalhos sobre "Whiteness" realizados por estudiosas norteamericanas como Janet E. Helms, 1990'; Beverly Daniel Tatum, $1997^{10}$ e Ruth Frankenberg, $1995^{11}$. Disto, Edith descreveu características recorrentes à identidade branca brasileira nas quais este discurso é marcado pela invisibilidade, distância e silenciamento sobre a existência deste "outro" negro, no caso. Para Edith, o branco

poder Público. Cidadania em Preto e Branco, discutindo as relações raciais".

8 Edith Piza é doutora em Psicologia Social pela PUC/SP .É uma das autoras do livro "Porta de vidro: uma entrada para branquitude". In: CARONE, Iray; BENTO, Maria Aparecida da Silva (orgs.). Psicologia Social do racismo: estudos sobre branquitude e branqueamento no Brasil. Petrópolis: Editora Vozes, 2002. p. 59-90.

9 Janet E. Helms é norte-americana. Ela é professora do Departamento de Conselho, Desenvolvimento e Educação Psicológica da Universidade de Boston e é diretora do Instituto para o Estudo e Promoção da Raça e Cultura da mesma universidade. Janet E. Helms é autora do livro "Black and White racial identity: Theory, research, and practice. Contributions in AfroAmerican and African studies", 1990, Editora Greenwood. Edmonton.

10 Beverly Daniel Tatum, norte-americana, é PhD em Psicologia Clínica pela Universidade de Michigan. Em 1997, Tatum escreveu o livro "Why are all the Black kids sitting together in the cafeteria?" pela editora Basic Books, Nova York.

11 Ruth Frankenberg nasceu na Inglaterra em 1957. Bacharel e Mestre em Ciências Sociais e Políticas, Arqueologia e Antropologia pela Universidade de Cambridge, Ruth se tornou em 1988 PhD em História da Consciência na Universidade da Califórnia. Sua dissertação deu origem ao livro: "White Women, Race Matters: The Social Construction of Whiteness", 1995. Ruth Frankenberg morreu no ano de 2007. 
não vê, não sabe, não conhece, não convive, não sente a discriminação. A racialidade do branco é vivida como um círculo concêntrico: a branquitude se expande, espalha-se, ramifica-se e direciona o olhar do branco. A branquitude, como conceito, traz à cena e nomeia o componente racial branco completamente neutralizado nas relações raciais, tornando visível o que socialmente se faz questão de velar; isto é, que a desigualdade, no ponto de vista das raças, é polarizada entre brancos e negros. Ainda segundo Edith em sua obra Porta de vidro: uma entrada para branquitude o termo branquitude também se destaca através dos seguintes pontos como:

- algo consciente apenas para as pessoas negras;

- há um silêncio em torno da raça, não é um assunto a ser tratado;

- a raça é vista não apenas como diferença, mas como hierarquia;

- as fronteiras entre negros e brancos são sempre elaboradas e contraditórias (positividade e negatividade na representação do negro podem habitar um mesmo lugar);

- há, em qualquer classe social, um contexto de ideologia e de prática da supremacia branca;

- a integração entre negros e brancos é narrada sempre como parcial, apesar da experiência de convívio;

- a discriminação não é notada e os brancos se sentem desconfortáveis quando têm de abordar assuntos raciais;

- a capacidade de apreender e aprender com o outro, como um igual/diferente, fica embotada;

- se o negro, nas relações cotidianas, aparece como igual, a interpretação é 
de exibicionismo, de querer se mostrar.

Ainda no trânsito dos significados sobre o conceito de branquitude, na introdução do Livro O Negro no Mundo dos Brancos, Florestan Fernandes elabora a seguinte ideia sobre "Embranquecimento" e "Branqueamento":

"O negro permaneceu sempre condenado a um mundo que não se organizou para tratá-lo como ser humano e como "igual". Quando se dá a primeira grande revolução social brasileira, na qual esse mundo se desintegra em suas raízes - abrindo-se ou rachando-se através de várias fendas, como assinalou Nabuco - nem por isso ele contemplou com equidade as "três raças" e os "mestiços" que nasceram do seu intercruzamento. Ao contrário, para participar desse mundo, o negro e o mulato se viram compelidos a se identificar com o branqueamento psico-social e moral. Tiveram de sair de sua pele, simulando a condição humana-padrão do "mundo dos brancos".

Essa situação constitui, em si mesma, uma terrivel provação. Que equilíbrio podem ter o "negro" e o "mulato" se são expostos, por princípio e como condição de rotina, a formas de auto-afirmação que são, ao mesmo tempo, formas de autonegação? No cume da ascensão social ou no fim de um longo processo de aperfeiçoamento constante, o indivíduo descobre que extrai o seu próprio valor, e o reconhecimento desse valor pelos outros, daquilo em que ele não é, decididamente, nem negro nem mulato, mas BRANCO! Para os analistas superficiais, esse imperialismo da branquitude é normal e necessário. Isso porque fomos levados a crer que a integração nacional do Brasil depende dessa forma unilateral de realizar nossa unidade nacional." (Fernandes, 1972, p. 15)

De alguma forma, os termos elencados dialogam entre si. Branquitude talvez seja um conceito interessante para entrelaçar "elitismo"/“aristocracia" e relacioná-los a periferia, negro e universidade pública. Num sentido prático; como num efeito de se ligar o estopim dos explosivos da implosão; penso que, por exemplo, o termo elitismo seja bem inteligível para quem está dentro e quem está fora da universidade pública. Vamos começar por você... 
Sim, você que lê este texto e que nunca morou na periferia, que sempre teve confortavelmente sua criadagem negra ou nordestina, que sempre estudou em colégios muito caros, que nestas escolas você tenha se acostumado a enxergar os negros sempre na limpeza ou nos serviços gerais, você que na vida sempre esperou menos de uma pessoa negra sem que você se desse conta disso, creio que você entenda bem sobre elitismo e como se herda este jeito de compreender nosso Brasil.

Agora se você não se identifica com o exemplo anterior, mas que lê este texto. Você que sempre lutou para entrar na universidade pública, mas foi rechaçado no vestibular desde o primeiro ano do fundamental, com professores que viam em seu rosto negro a inviabilidade para o conhecimento; creio que você entenda bem significados de elitismo e como se herda este jeito de compreender nosso Brasil. Como numa implosão, as três perguntas seguintes funcionam como sinais sonoros de aviso para que se afastar do lugar a ser implodido, pois os explosivos serão detonados.

Qual o seu lugar na Casa Grande?

Qual o seu lugar na Senzala?

Qual o lugar construído para o negro e a negra no audiovisual brasileiro?

Passada a primeira implosão, é hora de esperar a poeira abaixar e ver qual maquinários serão utilizados para aquilo que permaneceu em pé. 


\subsection{Analisando a demolição.}

Na obra Crítica da Imagem Eurocêntrica (2006), Robert Stam e Ella Shohat discutem o caráter intrinsecamente polêmico sobre a visibilidade de grupos historicamente discriminados (mulheres, negros, árabes, indígenas, etc) que frequentemente exprimem seus descontentamentos sobre estas mesmas expressões visuais. Estes autores denominam esta disputa inerente e insatisfação permanente como "Fardo da Representação". Se relacionarmos este termo com a representação do negro e da negra no audiovisual brasileiro contemporâneo, podemos compreender como há neste meio uma predominância de um ideal daquilo que significa branco por excelência. Por um viés sócio/antropológico (tendo em vista estudos de intelectuais dos anos 1930 como Gilberto Freyre, Sérgio Buarque de Holanda, Caio Prado Júnior que se debruçaram a compreender as relações sociais em nosso país), o olhar oriundo da construção deste ponto de vista pode ser compreendido num processo histórico colonial herdado em nossa nação no qual etnias distintas realizavam papéis definidos em nossa sociedade; no entanto, a sensação recorrente (reivindicação inclusive de movimentos negros brasileiros) é que estes aprisionamentos vindos dos mesmos papéis definidos construídos historicamente são atualizados em nossa sociedade numa forma de "Ser Branco como norma" ou desejo daquilo que significa embranquecimento. A Televisão Brasileira, principalmente as telenovelas, são exemplos da atualidade deste ideário. Segundo o já mencionado Joel Zito Araújo, em sua pesquisa $A$ Negação do Brasil, a telenovela brasileira se pauta pela negação do negro e da negra como 
protagonistas.

Já o cinema brasileiro compartilhou o tabu da cor de uma maneira diferente. No período das Chanchadas entre 1950 a 1960, o ator negro Grande Otelo era um dos protagonistas. Filmes que antecederam o Cinema Novo como Barravento (1962, Glauber Rocha), Aruanda (1960, Linduarte Noronha), Rio Zona Norte (1957, Nelson Pereira dos Santos), Orfeu Negro (1959) já traziam protagonistas negros e suas questões. No entanto, mesmo estes protagonismos não foram capazes de tornar possível negros(as) na formulação, confecção e produção de um filme. Fica latente em alguns filmes (Como Orfeu Negro, por exemplo) um sentimento de "Qual Negro o Branco quer ver?", ou caminhando mais além, "Qual negro é visível como protagonista dentro de nossa branquitude normativa?".

Durante os anos 1970 (período de franca expansão da televisão, movida por uma estratégia de integração nacional norteada pelo regime militar da época) o cinema brasileiro teve sua repercussão reduzida. Mesmo tendo produções fílmicas de grande bilheteria como Dama do Lotação (1978, Neville de Almeida), Dona Flor e Seus Dois Maridos (1976, Bruno Barreto), Eles Não Usam Black Tie (1981, León Hirszman) e a presença da Embrafilme como principal política governamental de fomento ao cinema, a televisão foi o veículo de comunicação privilegiado pelo mercado audiovisual e pela população. Nos anos 2000, período de retomada do Cinema Brasileiro motivada por políticas culturais de renúncia fiscal, a utilização de protagonistas negros é retomada, mas agora em registros polêmicos ligados a representação da periferia aliada a violência. 
Nesta atualidade, dentro da produção audiovisual brasileira atual, o termo "audiovisual periférico" é comumente usado por pessoas do meio audiovisual (produtores(as) diretores(as) e críticos de cinema e TV) para designar a produção audiovisual realizada por coletivos e/ou artistas audiovisuais que vivem, moram, situam-se ou têm como identidade seus espaços periféricos. Existe uma ligação atual entre esta produção e as experiências das oficinas Kinoforum de Realização Audiovisual (atividade do Festival Internacional de Curtas Metragens de São Paulo) que desde o ano de 2001 oferece oficinas audiovisuais em várias comunidades periféricas da cidade de São Paulo. Segundo a organização do Festival, um dos objetivos é desvendar novos olhares, universos e concepções de imagem, oriundos de grupos sociais que habitam essas regiões periféricas e que ainda têm acesso limitado aos circuitos de produção/exibição audiovisual.

A experiência da Kinoforum foi antecedida pelas realizações da ABVP (Associação Brasileira de Vídeo Popular) $^{12}$ e do vídeo popular dos anos 80 (19811990), que através de vídeo-documentários trazia imagens de ocupações em terrenos públicos e de lideranças sociais em espaços periféricos da época. De qualquer forma, esta maneira de produzir o audiovisual vindo de pessoas da periferia e/ou com sensibilidade a questões de pessoas que moram nela se apresenta atualmente como fruto de disputas pela representação e/ou auto-representação, contrapondo-se de maneira política à construção das imagens sobre periferia e de seus moradores advindas de grandes produtoras e produções audiovisuais.

12 A Associação Brasileira de Vídeo Popular Explicar história da ABVP inicia suas atividades na década de 80 do século XX. Nesta época, vários videastas integrantes de movimentos sociais utilizaram o vídeo comunitário como ferramenta de reivindicação social. Nesta época se iniciava a abertura política do Brasil diante de anos sob a ditadura do Regime Militar e também a tecnologia do vídeo se popularizava diante do barateamento dos equipamentos em vídeo. 
Eu também vivenciei ecos desta disputa pela representação da periferia na minha graduação em audiovisual na ECA/USP. No departamento de Cinema, Rádio e TV desta faculdade, participei de um projeto denominado "Rede de Telas" no qual filmes que retratavam espaços periféricos eram exibidos para público também de periferia. Nele, a ideia foi compreender como se dá a relação entre o público periférico e filmes que retrataram espaços da periferia, uma vez que havia poucas salas de cinema em bairros periféricos (Cenário que está se modificando atualmente através do grande número de shoppings centeres com salas de cinema que são construídos em diversos bairros periféricos da Cidade de São Paulo). De maneira conectada a este projeto, quatro produções acadêmicas da ECA/USP tematizam retratos da periferia relacionados, de alguma forma, a disputa pela representação da própria periferia. Estas produções foram a dissertação em mestrado de Ananda Stücker - A periferia nos seriados televisivos Cidade dos Homens e Antônia; a tese de doutorado Moira Toledo - Educação audiovisual popular no Brasil - panorama, 1990-2009, a recente tese de doutoramento de Gustavo Souza Pontos de vista em documentários de periferia: estética, cotidiano e política e a tese de Livre Docência de Esther Hamburger Da política a poética de certas formas audiovisuais. Todas elas abordam a problemática desta representação com foco em questões específicas. Stücker discute dois seriados que trouxeram a temática para a televisão. Toledo apresenta um extenso levantamento de experiências em educação audiovisual com perspectiva democrática. O desenrolar detalhado dessas inúmeras experiências e a discussão das noções de cidadania que orientam o trabalho pedagógico sugere a densidade de um universo fílmico que se adensa, e que foi discutido, do ponto de vista da análise fílmica, na tese de doutoramento de Gustavo Souza (recentemente 
defendida no Programa de Pós Graduação em Ciências da Comunicação da USP). Já a tese de livre-docência de Esther Hamburger elabora sobre a centralidade de interlocuções fílmicas na definição do espaço público brasileiro.

Em Fevereiro de 2009, quando ingressei no mestrado, entendi que poderia também contribuir com o debate sobre expressões audiovisuais sobre a periferia e de pessoas que moram nela uma vez que ela me diz respeito enquanto cidadão negro que sempre morou num bairro periférico e que frequenta o espaço acadêmico da universidade. Para tanto, meu projeto de mestrado propunha inicialmente analisar três séries televisivas que retratam comunidades periféricas e que gozaram de certa visibilidade, a saber: Turma do Gueto (2002 a 2005) - Rede Record / Casablanca, Cidade dos Homens (2003 a 2006) - Rede Globo / O2 Filmes e Antônia (2006 a 2007) - Rede Globo / O2 Filmes. O Princípio era contrapô-las a produções audiovisuais realizadas por coletivos culturais periféricos. A discussão comparativa embasaria a construção dramatúrgica da série televisiva "Sociedade Anônima"; série que retrata espaços periféricos e centrais através de um protagonista jovem negro motoboy que realiza cursinho popular para estudar numa faculdade pública de arquitetura. Pelas produções audiovisuais realizadas por coletivos ou artistas de periferia, pretendi analisar eram Videolência do Núcleo de Comunicação Alternativa (Zona Sul de São Paulo) e "Filmagens Periféricas" do Coletivo Filmagens Periféricas (Zona Leste de São Paulo).

No entanto, ainda em meu primeiro semestre de mestrado em 2009, eu percebi que para discutir e propor uma dramaturgia periférica, a síntese destes dois lados em disputa pela representação audiovisual deste espaço e das pessoas nela 
não seria o suficiente. É uma disputa muito desnivelada, produções periféricas, por exemplo, não contam com o aparato de produção audiovisual (luzes, câmera 35mm, som direto) tal qual se encontra em caras produções de maior visibilidade. O novo não está nesta síntese, mas sim no fortalecimento da "voz" proferida pelas produções periféricas. A síntese pode não necessariamente demolir a Casa Grande Audiovisual, e esse serviço tem que ser encarado. Assim, o desejo de dialogar "de igual para igual" é uma possibilidade de aprofundamento em discussões acerca da representação da periferia e como as raízes desta disputa nos diz muito sobre as relações raciais em nossa sociedade e acerca do que herdamos historicamente na representação do colonizador europeu para o colonizado negro e indígena.

Assim, a ideia na construção da série "Menina Mulher da Pele Preta" é partir da perspectiva de alguém que está na periferia e na universidade. Esta é a minha experiência e acredito que seja um momento importante para contar histórias neste outro ponto de vista. Sou negro, sempre morei na periferia de São Paulo (Vila Nova Cachoeirinha), sou radialista, cineasta, formei-me nestas profissões através de uma universidade pública onde vivi uma extrema elitização em seu acesso e em seu cotidiano. Além disso, eu participo desde o ano 2006 de coletivos culturais periféricos; creio que esta experiência deve "entrar no jogo" para elaboração destas duas dramaturgias audiovisuais. Na minha percepção, há algo recorrente que não é problematizado em produções como Cidade dos Homens, Cidade de Deus, O Invasor: a pessoa negra em condição de igualdade ou em lugares que denotam condição de igualdade. Nisto, pergunto o quanto a pessoa negra negocia ser branco ou negro para manter-se possível no lugar ou na condição em que está. 
Acredito que isto não se verifica apenas no audiovisual, mas na sociedade como um todo. Eu penso em quais momentos, para a pessoa negra, o exercício destes discursos conferem possibilidades de ascensão ou de manutenção. Minha sensação ou hipótese é que herdamos negociações nas quais os adjetivos e os significados ligados aquilo que se representa "branco" e o olhar do que representa "branco" para o "negro" atuam como regra ou norma. Penso o quanto uma ideologia embranquecedora opera na nossa sociedade como construções identitárias do negro numa condição de não igualdade. Aprofundando um pouco mais esta questão e relacionando-a com o nosso processo histórico como colônia que se utilizou de um processo escravocrata, penso como esta negociação do negro entre ser o que significa branco e o negro são herdados como acessos e impedimentos nos quais imperam alguns sentimentos de perda de identidade, de exotismo ou de subalternidade. Algo como uma colonização do olhar, da expressão, da representação, algo como uma "Escra-visão".

No centro dessas duas correntes de pensamento repousam três eventos históricos: a escravidão, o colonialismo e o apartheid. A estes eventos, um específico conjunto de significados canônicos foi atribuído. Primeiro, a ideia de que, através dos processos de escravidão, colonização e apartheid, o eu africano se torna alienado de si mesmo (divisão do self ). Supõe-se que esta separação resulta em uma perda de familiaridade consigo mesmo, a ponto de o sujeito, tendo se tornado um estranho para si mesmo, ser relegado a uma forma inanimada de identidade (objetificação). Não apenas o eu não é mais reconhecido pelo Outro, como também não mais se reconhece a si próprio. (Mbembe, 2001, p.174)

Esta ideia levantada por Achille Mbembe, ao descrever como se deu processos identitários dentro dos eventos históricos da África do Sul (tendo aí o contexto do processo do neo-colonialismo europeu), pode ser comparado em relação a preferência pelo que significa branco em nossa sociedade. Não que aqui 
tenhamos políticas públicas como o apartheid sul-africano que tornam visíveis as diferenças; lá Branco é branco e Negro é Negro e a negociação dos mulatos é difícil pois não há uma espécie de ascensão via branquitude como aqui no Brasil. Por outro lado, quando Achille traz esta observação: "Não apenas o eu não é mais reconhecido pelo Outro, como também não mais se reconhece a si próprio", é possível compreender como tais "Não reconhecimentos" de si mesmo se constroem em nossa sociedade brasileira tendo aqui o ideal daquilo que seja humano engendrado numa ideologia embranquecedora e que estabelece diversas zonas entre não ser e o ser outro no branco que for possível para o negro e o mulato. Elaborando também através de outra referência, o psiquiatra martinicano Frantz Fanon (1925 - 1961) pautou suas obras na relação da pessoa negra durante o processo neo-colonial. Num trecho de seu livro "Os condenados da Terra", Fanon traz a seguinte observação acerca das enfermidades psiquiátricas frequentes na população colonizada:

A verdade é que a colonização se apresentava, em essência, como uma grande provedora dos hospitais psiquiátricos. Em diversos trabalhos científicos, chamamos a atenção dos psiquiatras franceses e internacionais, desde 1954, sobre a dificuldade de "curar" corretamente o colonizado, ou seja, de fazer-lo totalmente homogêneo num meio social de tipo colonial. Como uma negação sistemática do outro, uma decisão furiosa de privar o outro de todo atributo de humanidade, o colonialismo empurra ao povo dominado a se colocar constantemente na pergunta: Quem sou eu na realidade? (Fanon, 1973, p 154) ${ }^{13}$

Relaciono o que Fanon trabalha como negação sistemática do outro com a

13 "La verdad es que la colonización, en esencia, se presentaba ya como una gran proveedora de los hospitales psiquiátricos. En diversos trabajos científicos llamamos la atención de los psiquiatras franceses e internacionales, desde 1954, sobre la dificultad de "curar" correctamente al colonizado, es decir, de hacerlo totalmente homogéneo en un medio social de tipo colonial. Como es una negación sistemática del otro, una decisión furiosa de privar al otro de todo atributo de humanidad, el colonialismo empuja al pueblo dominado a plantearse constantemente la pregunta: "¿Quién soy en realidad?"'” (Fanon, 1973, p.154) 
negociação do negro nos diversos significados atrelados ao ser negro e ao ser branco. Esta negação sistemática no nosso caso parece funcionar como algo normativo que nunca será alcançado; e como não se alcança a excelência deste algo normativo, a diferença se constrói e se habita; o lugar se faz. A Periferia pode ser este lugar, inclusive. Filmes como Cidade de Deus, O Invasor e Tropa de Elite trazem retratos de um espaço único, definido e colocado: A Periferia, A Favela. Os personagens que representam espaços periféricos podem ser positivados ou negativados, mas permanecem lá como uma jaula ou um zoológico que protege o olhar do espectador. Independentemente da distância (como no Rio de Janeiro, onde inúmeras favelas são próximas aos bairros "do asfalto') os lugares se constroem e estão certos para o que significa naqueles rostos geralmente negros que sempre iremos encontrar e representar idealmente nestes dois espaços. Para isto, eu lembrei de um trecho do livro "Quarto de Despejo" da escritora Carolina Maria de Jesus:

“... Fui ver a filmagem do documentário do Promessinha. Pedi os nomes dos diretores do filme para por no meu diário. (...) As mulheres da favela perguntavam-me:

- Carolina, é verdade que vão acabar com a favela?

-Não. Eles estão fazendo uma fita de cinema.

O que se nota é que ninguém gosta da favela, mas precisa dela. Eu olhava o pavor estampado nos rostos dos favelados.

- Eles estão filmando as proezas do Promessinha. Mas o Promessinha não é da nossa favela.

Quando os artistas foram almoçar os favelados queriam invadir e tomar as comidas dos artistas. Pudera! Frangos, empadinhas, carne assada, cervejas. (...) Admirei a polidez dos artistas da Vera Cruz. É uma companhia cinematográfica nacional. Merece deferencia especial. Permaneceram o dia todo na favela. A favela superlotou-se. $E$ os visinhos de alvenaria ficaram comentando que os intelectuais dão 
preferência aos favelados.

As pessoas que olhavam a filmagem faziam tanto barulho. O Bonito veio ver a filmagem. Perguntei-lhe se já foi filmado, porque ele é cantor.

- Não, porque não sou popular.

15 de Agosto... As mulheres chingavam os artistas:

- Esses vagabundos vieram sujar a nossa porta.

As pessoas que passavam na via Dutra e viam os bombeiros vinham ver se era incêndio ou se era alguem que havia morrido afogado. $O$ povo dizia:

- Estão filmando o Promessinha!

Mas o título do filme é Cidade Ameaçada.

(Jesus, 2010, p. 190-191)

O texto de Carolina Maria de Jesus em seu livro "Quarto de Despejo" traduz este sentimento de recorrência no retrato de espaços periféricos e das pessoas que moram nela... Uma recorrência naquilo que significa o negro como parte de nossa sociedade. Carolina poderia ter escrito este capítulo de seu diário depois de ter assistido a filmagem de Cidade de Deus, por exemplo. Se pensarmos nas séries televisivas que retrataram a periferia, eu me pergunto na recorrência destes retratos e significados. A série televisiva Cidade dos Homens realizou um retrato diferenciado daquilo que se fez no filme Cidade de Deus mesmo sendo as duas oriundas de uma mesma empresa produtora, a O2 Filmes. Nesta série não é somente a favela que é retratada pela lente da violência (como acontece no exemplo fílmico citado), há episódios em que os garotos protagonistas enfrentam dificuldades "no asfalto" (fora da favela) vivenciados pela violência exercida naquilo que eles poderiam significar em corpo e rosto de garotos bandidos. Citando um exemplo, no episódio Correio ( $3^{\circ}$ da primeira temporada), Laranjinha e Acerola realizam o serviço de entrega de 
correspondências na favela onde moram. Num dado momento, um dos moradores, que está bêbado ou fora de si, recusa-se a receber uma carta endereçada a ele. Para realizar este serviço de Correio na Favela, Laranjinha e Acerola foram ameaçados pelo chefe traficante de drogas local para realizarem o serviço sem nenhum erro, caso contrário eles poderiam ser mortos. A dupla entende que a recusa da carta pelo morador pode ser considerada como uma falha grave no serviço e decidem devolve-la ao remetente que mora na rua Haddock Lobo. Mas a dupla não consegue devolver, pois são recebidos de maneira bastante agressiva por um porteiro de um prédio situado no bairro da Tijuca na tal rua Haddock Lobo. Este porteiro alega que o endereço é da cidade de São Paulo e inclusive pergunta aos garotos se eles sabem ler. Esta é uma das cenas pela qual pode ser considerada a representação da maneira violenta com que "o asfalto" recebe esses garotos.

A relação com "o asfalto" não era o foco da série Cidade dos Homens, mas era uma das passagens na vida daqueles dois adolescentes moradores de uma favela onde o comando do tráfico de drogas e as investidas da polícia têm grande peso no cotidiano daquele lugar. Apesar deste contexto, a vida segue para os adolescentes Laranjinha e Acerola que enfrentarão diversos dilemas pertinentes a esta fase de suas vidas. Cidade dos Homens terminou no ano de 2006 e uma das forças desta série televisiva foi retratar algo invisível até então na televisão brasileira: Realizar uma série que retratasse a favela pelo ponto de vista de dois adolescentes negros moradores dela. O próprio título da série convida o espectador a entrar nesta OUTRA cidade que até então seria invisível pelo ponto de vista comumente exercido na televisão (que torna visível a favela geralmente através de reportagens realizadas em incursões das polícias nestas áreas). A dupla Laranjinha e Acerola seria este 
outro que se relaciona com o espectador como que the revelando um universo diferente, aquele de dentro da favela.

Neste sentido, ficam as seguintes perguntas: Esta relação estabelecida ofereceu possibilidade ao espectador para que ele se identificasse com os dilemas dos adolescentes negros Laranjinha e Acerola? Ou eles funcionaram como um "outro-negro-objeto" que apresenta de maneira segura este outro lado da cidade; sublinhando este lugar, naqueles rostos, reiterando-se necessariamente este outro para se definir fronteiras na nossa sociedade? A série teria atendido um fetiche das pessoas "do asfalto" em subir a favela tendo os adolescentes Laranjinha e Acerola como "tranquilos guias turísticos" deste lugar?

Ao analisar esta série, percebo que a força da experiência de apreciar a série estava em fornecer retratos deste outro lugar, a favela. No entanto, não necessariamente este foco estaria na identificação do espectador com os personagens protagonistas que habitam este lugar. Acerola e Laranjinha fazem parte de um discurso maior que elucida as especificidades e semelhanças da "Vida no morro" e da vida "no asfalto". É possível elencar episódios como Sábado, A coroa do imperador, Hip-hop Sampa, Correio, entre outros, nos quais se torna evidente algo do tipo: "Vamos mostrar como este outro realiza tais coisas" ou "Como funciona o cotidiano deste lugar através destes garotos". No episódio Sábado, por exemplo, há o evento de uma festa funk que mobiliza os jovens da favela onde Laranjinha e Acerola moram. A narração over de Laranjinha e de Acerola dão conta de explicar como funciona um baile funk e também quais são as intenções de cada um destes adolescentes protagonistas naquela festa. Pelas suas narrações, fica explicado que 
Laranjinha deseja beijar um certo número de garotas na festa, já Acerola quer ser visível especificamente para a garota por quem ele está apaixonado. Garotas da festa têm, em alguns momentos, seus pensamentos revelados através do mesmo recurso narrativo e denotam hesitação, ao contrário do que vivenciam na festa. Ações que acontecem com outras personagens mulheres (como a personagem Poderosa, interpretada pela atriz Roberta Rodrigues e outra garota que tem seus cabelos cortados pelos traficantes do local) reforçam essa vocação em revelar ou mostrar algo que acontece de maneira específica neste lugar, como num estudo antropológico.

Para as possíveis relações de identificação ou verossimilhança no retrato das pessoas deste lugar, vale o que se convencionou associar com a favela: as gírias, o jeito de ser, a sociabilidade do lugar; e nesta apropriação fica uma segurança em novamente (e tranquilamente) aprisionar representações dos rostos e corpos negros no retrato da periferia. Cidade dos Homens, em sua narrativa permeada pela voz over, traz uma sensação de que a inclusão do espaço periférico na visibilidade televisiva, legitimado inclusive pelos seus protagonistas adolescentes, exerce algo que exclui, ou seja, o OUTRO (Laranjinha ou Acerola, por exemplo) no lugar da periferia está lá como fato dado. Não desejo aqui desconsiderar esta série como um todo e negar a diversidade de seus momentos, mas aliando o fato de Cidade dos Homens ser produzida por pessoas que não são da favela com a circunstância desta verve em tecer a relação com o espectador através destas explicações que acontecem neste outro lugar da favela, fica a questão daquilo que se reitera no retrato do negro e da negra. Por exemplo: por que na novela cotidiana os dramas são humanos e nesta série, ou mesmo em Turma do Gueto, Antônia, Cidade de 
Deus, o drama é da favela e/ou da periferia?

O filme Uma Onda no $\operatorname{Ar}$ (2002, Helvécio Ratton) pode ser considerado, por exemplo, um experiência diferenciada porque traz o protagonista negro Jorge (vivido pelo ator Alexandre Moreno) que deseja modificar simbolicamente o lugar onde ele mora através da realização de uma rádio comunitária. Diferenciado porque o foco da história está justamente no poder de ação do protagonista em modificar o lugar que está. Na história, Jorge se relaciona com as pessoas do seu bairro num sentido de poder construir uma voz que venha daquelas pessoas ali da favela de Belo Horizonte. Jorge, que estudou em colégio particular com uma espécie de bolsa, foi vítima de preconceito racial, largou seus estudos e focou na possibilidade de seguir sua vida e construir uma emissora de rádio de (e para) sua comunidade. O filme evoca a superação e Jorge é laureado quando funcionários da ONU o convidam a receber um prêmio pela sua iniciativa em realizar uma rádio comunitária, reconhecimento que até então não acontecera vindo de autoridades brasileiras em Telecomunicações e/ou em Comunicação Social. Os problemas vivenciados por Jorge e retratados no filme são enfim superados e vale ressalvar que esta obra se baseia em uma trajetória real, o que o aproxima das experiências de docudrama do cinema britânico e realça a inexistência de uma dramaturgia que imagine personagens com densidade própria capazes de realizar feitos transformadores como de Jorge, fundador da Rádio Favela. Re-assistindo a este filme em 2007 (numa projeção do Coletivo CineBecos, em que participo), eu refleti que a trajetória de superação de Jorge possivelmente esvazia os motivos dos embates que o protagonista encontra em sua jornada. Por exemplo, se a discriminação racial sofrida por Jorge fica, no filme, representada apenas como mais uma dificuldade 
enfrentada/vencida pelo protagonista e não como caráter fundante nos diversos impedimentos vivenciados por ele. Este fato tem relação com aquilo que Edith Piza desenvolve sobre branquitude: a discriminação não é notada e os brancos se sentem desconfortáveis quando têm de abordar assuntos raciais. É uma questão política crucial em nossa sociedade, mas que permanece invisível em sua representação. Tratá-la significa compreender quais valores são herdados e reiterados em nossa sociedade para se exercer a distância, talvez tal qual àquela em que o senhor da casa grande exercia seu lugar definido e o escravo também exercia o seu.

Entre 2002 a 2004, os três primeiros anos de minha graduação em audiovisual na ECA/USP, eu acompanhei com certa frequência a série televisiva Turma do Gueto (exibida entre os anos de 2002 a 2005), exibida pela Rede Record. $\mathrm{Na}$ época de estreia desta série, cadernos televisivos de jornais diários impressos como Folha de São Paulo e hebdomadários como a revista Veja descreviam Turma do Gueto como uma obra audiovisual disposta em olhar positivamente a periferia. Esta série televisiva foi concebida pelo cantor e compositor José de Paula Neto, conhecido como Netinho de Paula, que é um cidadão negro e morou boa parte de sua infância/adolescência no espaço periférico dos conjuntos habitacionais populares da Cidade de Carapicuíba (Região Metropolitana da Cidade de São Paulo). Isso em si gera a possibilidade de um novo outro olhar, uma vez que as pessoas mentoras da produção audiovisual brasileira dificilmente surgem na periferia e muito menos são pessoas negras na maioria. A sinopse oferecida pelo site da série trazia a seguinte informação: 
"Turma do Gueto é uma série como você nunca viu: ousada, inovadora e inédita. Tendo como pano-de-fundo a periferia paulistana, a série vai mostrar o cotidiano da "Escola Municipal Quilombo", onde professores e alunos lutam para continuar ensinando e aprendendo; e da sua comunidade, onde moradores se esforçam para viver com dignidade.

Neste ambiente polivalente, e com cerca de quarenta personagens, as tramas da série vão se desenrolar como na vida. Histórias de amor, de violência, de amizade, de drogas, de música, de lealdade e de traição. Irão levar o telespectador a uma viagem direta do seu televisor às ruas da periferia brasileira." (Fonte: www.turmadogueto.com.br)

"A boa estréia de Turma do Gueto confirma um fenômeno apontado pelo longa-metragem Cidade de Deus e por seu filhote televisivo, a minissérie Cidade dos Homens, exibida pela Rede Globo no mês passado: o interesse do público pelo tema da vida nos bairros pobres e violentos. Mas é preciso tomar cuidado com as comparações. Assim como no filme de Fernando Meirelles, boa parte dos 36 atores que compõem o elenco de Turma do Gueto foi arregimentada em grupos de teatro amador. Só que eles não receberam nenhum treinamento especial para atuar diante das câmeras, ao contrário do que ocorreu com os protagonistas de Cidade de Deus. Também as figuras conhecidas que participam do programa da Record, como a cantora Simony e o rapper e ex-presidiário Afro- $X$, em nada contribuem para melhorar o nível das interpretações - muito pelo contrário.Turma do Gueto é tosco na direção de atores, tosco nos diálogos e na dramaturgia. Mas tem o mérito da autenticidade e de abordar sem rodeios a violência (só no primeiro episódio foram duas mortes)". (Revista Veja, 13 de Novembro de 2002 http://veja.abril.com.br/131102/p 146.html )

A série trazia o cotidiano da comunidade que vive em torno da escola pública

Quilombo. Durante duas temporadas, Netinho de Paula interpretou o personagem principal "Professor Ricardo" que atuava como mediador das diversas questões e conflitos existentes nesta comunidade e na escola. A atriz Ana Paula João Demambro atuou como a cabeleireira Tina, que realizava par romântico com Ricardo na série. Segundo o instituto de pesquisas IBOPE, Turma do Gueto chegou a ter $10 \%$ - 11\% da audiência apresentada em seu universo de amostragem; número muito significante para a emissora Record, que até hoje em dia disputa números como este em outras de suas atrações. A estrutura dramatúrgica de Turma do Gueto 
se aproximava a uma telenovela através de seus diversos núcleos de personagens; no entanto, diferente das novelas e mais próxima da estrutura de seriado mesmo, para cada capítulo havia um tema ou uma história a ser trabalhada. Apesar do sucesso de Turma do Gueto; no ano de 2004, Netinho de Paula saiu desta série e alegou que o objetivo inicial dela havia se perdido, para ele a necessidade de manter a audiência do programa estava diretamente ligada a mudança de foco, quando esta produção televisiva passou a ser pautada pelo assunto violência aliado ao tráfico de drogas. Neste período, a série começou a ser direcionada pelo conflito dos traficantes Jamanta (interpretado pelo ator Nill Marcondes) e Nenê (interpretado pelo ator Alexandre Frota). A introdução dos novos personagens gerou muitas cenas de ação com troca de tiros e perseguições entre os grupos capangas destes dois personagens além do núcleo policial presente na trama. Interessante compreender que, não por acaso, quem continuou a realizar/conceber a série foram pessoas que não vivem na periferia e que não têm sensibilidades oriundas de uma vivência nela. Ainda mais interessante é notar que a produtora Casablanca (que produziu e realizou a série) não é protagonizada por pessoas vindas da periferia e tampouco tem pessoas negras em seus quadros de roteiristas, produtores e diretores.

Ainda se fosse somente a Casablanca... É possível elencar inúmeras outras produtoras como O2 Filmes, loiô Filmes, Conspiração Filmes, Superfilmes, Dezenove Filmes, Coração da Selva... Quais delas têm efetivamente negros em seus quadros? Tenho que exaltar e agradecer que pelo menos existiram dois: o escritor Paulo Lins (que escreveu a obra que fomentou a produção do filme Cidade de Deus) e Netinho de Paula, com Turma do Gueto? No caso desta última, diante da significativa audiência, ficam as perguntas: Seriam pessoas de classe média que 
mais uma vez colocariam 'palavras na boca' naquilo que significa periferia? São elas que detém a autoridade única a falar sobre periferia? É provável, mas generalizar seria um tanto perigoso. Talvez seja um compartilho ideológico daquilo que representa estar em "classe média" e assim exercer a branquitude. Não pelo que a classe média é, mas pelo que ela significa. Mas fica a pergunta: Porque o tema periferia presente nestas séries que gozaram de grande audiência não continuou tão visível em outras obras audiovisuais como o recente filme Bróder de Jeferson De e a série televisiva Natália, veiculada pela TV Brasil?

Acredito que o ocorrido em Turma do Gueto seja muito significativo até para as produções atuais de maior visibilidade que retratam espaços periféricos, pois também representam a recorrência de um discurso único daqueles que se colocam como autoridade única a falar sobre periferia. Um discurso ou frases dele que mantém lugares de privilégio e de exclusão. Partilho da ideia de Carolina Maria de Jesus, pois dentro dessa visibilidade audiovisual da periferia na TV e no cinema, noto que ninguém gosta da favela, mas simbolicamente precisa dela para se enclausurar a diferença. Nesta clausura da periferia fica uma mistura: Tratá-la como exótica e ao mesmo tempo repugnante, separando-a. Algo muito próximo àquilo que historicamente construímos na nossa sociedade em relação ao negro e a negra: O exótico (desejado) e o repugnante (indesejável). Nestas duas formas, aquilo que significa branco, em seu poder, enclausura as relações assegurando seus lugares: 0 Branco e o Negro. O Centro e a Periferia. Mas a própria negociação ou jogo entre esses "desejados" e "não desejados" é uma maneira para se legitimar, muitas vezes, que as práticas de discriminação racial ao negro são pontuais em nosso país. Nesta negociação, para o negro e a negra, o pertencer a esta sociedade tem significado 
Branco, por excelência. Em relação a nossa representação ou ao fardo dela, tanto na positividade quanto na negatividade do retrato do negro e da negra há um processo de clausura que efetivamente não é construída por um olhar negro. Assim, vejo que a construção da representação da periferia nestas obras é também um dos resultados do exercício de nossa branquitude. O desafio está em passarmos da representação para concentrarmos nas expressões cinematográficas não imersas na ideologia da branquitude. Nela já temos brilhantes experiências já consolidadas como o próprio cinema de quebrada ou, por exemplo, o Vídeo nas Aldeias.

Analisar estas produções audiovisuais de maior visibilidade não é desconsiderá-las por completo, pelo contrário. O objetivo aqui foi compreender como nos diferentes retratos, positivos ou negativos, há recorrências de clausura na representação do negro e da negra no nosso audiovisual. Para isto, foi necessário desconstruir as obras audiovisuais colocadas aqui. Estas que pretenderam realizar/tecer/adentrar ao universo da periferia e das pessoas que moram nela. Tendo em mente a recorrência de exclusão que valida inclusive a quase ausência de negros e negras na elaboração de uma produção audiovisual no nosso país; a presença de protagonistas negros nestas produções audiovisuais de maior visibilidade que retrataram espaços periféricos, sejam elas realizadas por um viés positivado ou negativo, revelam recorrências de branquitude que se entrelaça a nossas representações audiovisuais.

\subsection{A Periferia sumiu no audiovisual atual?}

Nesta fase da demolição, metaforicamente utilizo retro-escavadeiras. É um 
processo em que explosões controladas não são mais necessárias. Uma retroescavadeira é capaz de derrubar paredes e assim juntar os restos para colocá-los num caminhão ou num outro lugar.

Ao observar o crescimento de uma "nova classe média", "nova classe C" ou "classe média de batalhadores" como se fala normalmente nos noticiários telejornalísticos ou impressos, eu percebo uma presença menor da visibilidade dos espaços periféricos e de seus moradores na grande mídia se compararmos a quatro ou cinco anos atrás (como em 2006) em que tínhamos um seriado como Antônia, Cidade dos Homens e ainda reprises finais da série Turma do Gueto. Não necessariamente isso se dá pelo menor número de produções audiovisuais que retratam periferia, afinal temos exemplos como os filmes Tropa de Elite 2 (2010), Bróder (2011) e a série televisiva Natália (2011, TV Brasil).

Tropa de Elite 2 é um exemplo interessante, pois seu foco não está no retrato do cotidiano das favelas dominadas pelas milícias, mas sim na questão ética da profissão policial que desvela uma sensação de que está "tudo dominado" no que tange à corrupção sistêmica na política. É importante provocar em relação a Tropa de Elite 2, pois nesta obra os pretos e as pretas do subúrbio representado estão lá quase apenas para bater palma ou executar um samba para os personagens que representam milicianos, não por acaso brancos. Quem poderia ser protagonista no primeiro filme, no caso o personagem policial do Batalhão de Operações Especiais da Polícia Militar do Rio de Janeiro feito pelo ator negro André Ramiro, não chegou ao tento. Aliás, foi morto no segundo filme. 
Neste sentido, o filme Cinco Vezes Favela, agora por nós mesmos (2010) traz uma proposta interessante ao indicar que a construção do olhar desta obra audiovisual é oriunda de quem está no espaço da favela. Com inspiração na iniciativa de jovens cineastas dos anos 60 oriundos das atividades dos Centros Populares de Cultura da União Nacional dos Estudantes e que realizaram o longa metragem Cinco Vezes Favela (1962; León Hirszman, Joaquim Pedro de Andrade, Cacá Diegues, Miguel Borges e Marcos Frias); cineastas moradores de subúrbio e de favela no Rio de Janeiro foram treinados e capacitados por realizadores como Daniel Filho, Ruy Guerra e o próprio Cacá Diegues através de oficinas audiovisuais viabilizadas pelo coletivo Nós do Morro (que fomentou inclusive o elenco do filme Cidade de Deus) e assim propuseram a realização de um longa metragem dividido em cinco episódios que retrata a favela através de olhares oriundos de quem tem vivência nestes espaços.

Cinco Vezes Favela, Agora por nós Mesmos é dividido nos episódios Fonte de Renda (direção de Manaíra Carneiro e Wagner Novaes), Arroz com Feijão (direção de Rodrigo Felha e Cacau Amaral), Concerto para Violino (Leandro Vidigal), Deixa Voar (Cadu Barcelos) e Acende a Luz (Luciana Bezerra). Cada um dos episódios varia seus registros entre o drama e a comédia tratando assim cada tema diferente ligado a favela e a pessoas moradoras dela. O primeiro episódio, Fonte de Renda, traz o drama de um jovem negro morador da favela Maicon (Sílvio Guindane) que estuda o curso de direito numa grande faculdade carioca. Para sustentar seus estudos e seus custos, ele decide vender drogas para os outros alunos que são oriundos brancos de classe média alta na maioria, mas isto volta contra si quando seu irmão menor de idade ingere acidentalmente certa quantidade de cocaína. Arroz 
com Feijão mostra das desventuras de Wesley (Juan Paiva), um garoto que ao tentar roubar uma galinha da venda do sinistro Seu Manoel (Ruy Guerra), pensa em proporcionar ao seu pai Raimundo (Flávio Bauraqui), que faz aniversário, um prato que varie além do arroz e feijão cotidiano. Concerto para Violino mostra a trágica história de amor entre a violinista Márcia (Cíntia Rosa) que está em compasso de espera para uma oportunidade de estudos musicais na Europa e Jota (Thiago Martins), traficante local que está sendo perseguido pela polícia. Deixa Voar mostra a história de Flávio (Vítor Carvalho), um adolescente que gosta da jovem Carol (Joyce Lohanne), mas que mora no bairro ao lado dominado por uma facção rival de onde a garota reside. Numa certa ocasião, o rapaz empina uma pipa e a perde quando tem sua linha cortada, fazendo com que o brinquedo voe para o bairro dominado pela facção rival. Sua missão será recuperar a pipa neste outro bairro que irá descobrir e nisto ele descobre que o bairro vizinho é tal qual como o bairro onde ele mora. Acende a Luz traz uma história natalina no qual o técnico pernambucano em eletricidade Cimar (João Carlos Artigos), que trabalha numa empresa concessionária de energia, tenta religar uma conexão falha na favela. Devido a demora, os moradores ficam nervosos e só aceitam a saída do técnico se ele religar a luz, mas ele alega que deve sair para substituir a peça defeituosa. Moradores impedem a saída de Cimar, que só lhe resta comemorar o natal tentando arrumar a conexão elétrica junto com a comunidade local.

A força do filme Cinco Vezes Favela, Agora por Nós Mesmos está no descolamento dos estereótipos; ou seja, se a princípio poderíamos reduzir ou simplificar as questões ao ver as imagens e personagens da favela; através das histórias dos personagens, o filme traz tais quebras de lugar comum. O próprio 
episódio Deixa Voar é um exemplo no qual tanto espectador e personagem principal esperam que o adolescente Flávio seja pelo menos recebido com hostilidade neste outro bairro, mas ao perceber que este bairro é como o seu, ele é contemplado pelo amor que nutre por Carol. Nestas quebras de expectativas ligadas ao preconceito que se tem do espaço favela e seus personagens, não há necessariamente discussão racial ou problematizações sobre os personagens acerca de atribuições ao negro, pardo ou branco apesar de boa parte do elenco ser negra.

Cinco Vezes Favela, Agora por Nós Mesmos foi produzido por Cacá Diegues e Renata Almeida Magalhães (reconhecida produtora executiva e diretora de produção cinematográfica principalmente de filmes do cineasta Cacá Diegues). Este filme conseguiu visibilidade razoável em festivais cinematográficos dentro e fora do Brasil e inclusive ganhou prêmios no Festival de Cinema de Paulínia 2010 e no Grande Prêmio Brasileiro de Cinema 2010. Conversando com o diretor cinematográfico Luciano Vidigal (diretor do episódio Concerto para Violino) em Novembro deste mesmo ano de 2010 em virtude do IV Encontro de Cinema Negro, nós tratamos sobre as dificuldades de se viabilizar projetos audiovisuais. Luciano me disse que ele tentou editais para um documentário seu sobre times de várzea no Rio de Janeiro. Indaguei que a experiência do longa-metragem que ele participou o favorecia muito para obter recursos para realizar seu projeto. No entanto, Luciano me disse que o fator determinante para que Cinco Vezes Favela, Agora por Nós Mesmos fosse produzido se deveu a presença de Cacá Diegues e Renata Almeida Magalhães na produção deste filme, garantindo assim a viabilização financeira desta produção cinematográfica. Para mim ficou uma sensação de que este filme foi possível mediado pela tutela destes trabalhadores/realizadores cinematográficos 
consagrados (como Daniel Filho e Cacá Diegues, por exemplo). Talvez Cinco Vezes Favela, Agora por Nós Mesmos não existisse ainda se os seus cineastas ou mesmo o grupo Nós do Morro tentassem dialogar diretamente com os departamentos de marketing de empresas e estatais para captação de recursos. Porque necessariamente esta Tutela se constrói? Ela se faz temporária ou é recorrente? Por que, até o momento, a experiência acumulada por estes cineastas na realização deste filme não se reverteu ainda a favor do potencial de realização autônoma deles?

O filme Bróder (que estreou em 21 de Abril de 2011) de Jeferson De e a série televisiva Natália (produzida a partir de seleção em edital do Ministério da Cultura em parceria com a TV Brasil e estreou nesta emissora pública em 01 de Maio de 2011) são também exemplos atuais de obras audiovisuais que retratam espaços periféricos. Bróder traz um protagonista branco chamado Macu, interpretado pelo ator Caio Blat, e retrata o bairro paulistano do Capão Redondo ${ }^{14}$ por um viés que interliga experiências humanas de amizade a contexto de violência. A série televisiva Natália tem uma mulher negra como protagonista e é interpretada pela atriz Aisha Jambo. O subúrbio retratado nesta obra é o bairro de Marechal Hermes.

Natália é uma garota virgem, negra, evangélica e pobre (Classe D), ela trabalha como balconista num bar-café num bairro sofisticado do Rio de Janeiro. Numa ocasião, um olheiro fotógrafo branco de classe média alta que trabalha para uma grande agência de publicidade vai tomar um café neste bar. Num dado

14 Nos anos 90 e início dos anos 2000, era frequente associar o bairro paulistano periférico do Capão Redondo a criminalidade. $O$ bairro tinha manchetes diárias em jornais e telejornais popularescos como "Notícias Populares" e "Aqui Agora", respectivamente. Por outro lado, sua visibilidade também se deu, em grande parte, através das músicas do grupo de RAP Racionais Mc's que tem como moradores deste bairro alguns de seus integrantes . 
momento ao ver Natália, este olheiro-fotógrafo sente desejo pela garota e ele a convida para uma sessão de fotos para uma campanha de lingerie. Natália reluta por causa de sua religião, mas decide participar. Ao contrário do argumento colocado pelo olheiro no qual as fotos teriam valor como um catálogo interno para a agência de publicidade, as fotos de Natália entram como catálogo de uma empresa de lingerie; logo estas fotos estão estampadas em outdoores por todo Rio de Janeiro. Natália se torna uma mulher negra que desperta desejo tanto na comunidade da igreja evangélica onde frequenta, quanto na agência em que passa a trabalhar como modelo.

No sétimo capítulo veiculado no dia 03/07/2011 pela TV Brasil às $22 \mathrm{~h}$ e 30min, Natália já é modelo fotográfica e é disputada por dois homens, um deles é o fotógrafo que a convidou para ser modelo fotográfica, o outro é um jovem empresário branco que a descobre (novamente a palavra) num almoço luxuoso numa festa chique. Nesta festa, realizada numa enorme mansão, Natália é a única negra no local uma vez que o fotógrafo olheiro (agora seu namorado) não pode comparecer a festa por compromissos de trabalho, fato que entristece muito Natália. A solidão da moça construída nesta festa não passa por critérios de raça, mas está sim baseada na sua carreira como modelo de grande visibilidade que vive o contrasenso de sua fama construída. Num dado momento, Natália conversa com outra convidada da festa que, na trama, fora uma atriz de grande visibilidade, mas que vive um atual ostracismo. Segundo esta atriz, ao ver a garota sozinha na festa, a fama deve ser encarada com cautela, pois a fama é passageira. Nos capítulos que assisti no momento (4 episódios, num total de 13), a série não problematizou olhares embranquecedores e masculinizantes a que a negra Natália está sujeita como 
modelo fotográfica e de passarela. Uma outra personagem que é a irmã de Natália, também negra, aproveita a fama da irmã para sair com um pretendente rico e branco, mas ela permanece no bairro de Marechal Hermes com sua filha recém nascida. Outro dado importante desta série é que ela goza de pouca visibilidade em audiência, o horário noturno das $22 \mathrm{~h}$ e $30 \mathrm{~min}$ de domingo é polarizado entre a revista televisiva "Fantástico", da Rede Globo, e o Programa Sílvio Santos, do SBT; dois programas de têm a maior parte da audiência neste horário. A TV Brasil que veicula esta série ainda aparece com restrições de Sinal em todo Brasil. Em São Paulo, a TV Brasil está restrita aos canais UHF analógico e operação de televisão por assinatura (Cabo e Digital via Satélite). Não chega a ser um canal que disputa audiência em relação a outras emissoras de TV.

No filme Bróder, o personagem principal Macu constrói suas relações na maior parte dentro do bairro periférico do Capão Redondo. No dia de aniversário de Macu, sua mãe (interpretada pela atriz Cassia Kiss) e sua irmã de criação (interpretada pela atriz Cíntia Rosa) preparam uma festa. Fica nítida a relação difícil que Macu tem com seu padrasto (Aílton Graça) e aos poucos, quando acompanhamos Macu pelo bairro, notamos que ele tem ligação com a criminalidade. Os amigos de Macu são Pibe (Sílvio Guindane), um rapaz negro que está desempregado, constituiu família recentemente e mora no centro da cidade; e Jaiminho (Jonathan Haagensen), um rapaz também negro que se tornou um famoso jogador de futebol e que está prestes a ser convocado para a Seleção Brasileira. A festa se faz com a presença desses convidados e aos poucos se revelam alguns dramas que permeiam todos os personagens. Jaiminho e a irmã de Macu tiveram uma relação amorosa que resultou na gravidez da moça. Pibe re-encontra a ex- 
namorada no bairro onde morou. Macu ainda está ligado de maneira quase determinística a criminalidade e para isso, ele se vê forçado a participar do planejamento no pretenso sequestro de Jaiminho. O sequestro não acontece, Macu é fiel a amizade que tem pelo amigo, mas por conta dela, Macu é assassinado pelos bandidos comparsas.

O filme caminha numa dramaturgia que traz o elemento trágico na construção da história de Macu naquele bairro periférico. Há vários elementos disto no filme e dentre eles, eu destaco a cena em que Macu, ao re-encontrar seus amigos, vê o cenário de um crime no bairro, mas ele não se compadece e dá a entender que há certa normalidade daquela cena naquele lugar. Há um outro ponto muito interessante na construção do filme que é a interpretação do ator Caio Blat sobre o personagem Macu. Na revista "Raça Brasil" (setembro/2010), o diretor do filme Jeferson De revela que Caio Blat ficou lisonjeado com o convite para o filme, pois este ator sempre quis fazer personagem "Negão". Neste sentido, a interpretação de Caio Blat tem excessos caricaturais (como nas caretas que o ator faz quando o personagem Macu recebe um telefonema de seus comparsas ou na sequencia do bar onde o mesmo protagonista comemora o re-encontro com seus amigos de infância e se inicia uma briga um tanto inverossímil entre os clientes deste boteco). Interessante ver que ao interpretar um papel de "Negão", coube colocar o personagem Macu num determinado lugar na dramaturgia não por acaso trágico. Fica a impressão, neste filme, que novamente se evidencia a percepção de "Lugar do Negro", apesar de ser representado por um personagem branco. Nesta representação, o lugar da violência também acaba sendo um caráter definidor nesta história da periferia, mesmo que retratos humanizados advindos das amizades de 
Macu e de sua família tornem mais complexas estas representações. De maneira geral, em Bróder, a violência que valida o filme e permeia a vida de Macu não é construída através de relações em nossa sociedade que estruturam a existência destes lugares. Por outro lado, fica a experiência na qual o lugar periférico é palco para complexidades vivenciadas por Macu e pelos outros personagens, a experiência humana dos personagens é ressaltada no final do filme, apesar de indicar um determinismo naquele lugar periférico. Segundo o site www.filmeb.com.br (revista eletrônica especializada em borderô cinematográfico) nas duas semanas que Bróder ficou em cartaz, as 30 cópias em $35 \mathrm{~mm}$ do filme renderam um acumulado bruto de $R \$ 298.238,00$ na receita dos ingressos e foi visto por 27.756 pessoas nos cinemas de todo o Brasil. Este número é considerado baixo diante das expectativas em relação ao número de cópias lançadas no mercado.

Bróder é um filme que sugere uma presença nova no audiovisual brasileiro de realizadores(as) negros(as) que procuram se firmar como realizadores audiovisuais dentro do nosso "mainstream" (cenário principal) audiovisual. Apesar desta mudança sensível, algo é recorrente quando produções audiovisuais (aquelas feitas com incentivo fiscal, editais e protagonizados por produtoras cinematográficas estabelecidas neste meio) tenta representar uma história que se passa e que problematiza questões de pessoas que vivem em subúrbios e periferias: $\mathrm{O}$ negro não é representado como construtor de sua igualdade e para tanto, ele se "arma" na sua periferia. Para isto, é muito significativo que Bróder, Natália e Cinco Vezes Favela, Agora por Nós Mesmos ao propor maiores complexidades em seus retratos audiovisuais, não conseguiram uma visibilidade tal qual como aconteceu com Cidade de Deus, Cidade dos Homens e a série televisiva Antônia. Será que passou 
o tempo de se problematizar periferia no nosso audiovisual? Será que os realizadores de Tropa de Elite e Cidade de Deus se tornaram as autoridades únicas legítimas para retratar pessoas em espaços periféricos? Acredito que o problema ainda não tenha uma resposta e é neste contexto, na oferta de alguma delas, que meu trabalho se coloca. A ideia não é ser a resposta única para estes dilemas até então apresentados, mas sim a proposta está em realizar um produto audiovisual que venha destas reflexões.

Caminhando nestas legitimidades, lembro que desde meu tempo de criança, quando eu assistia a telejornais "populares" como o extinto Aqui Agora, realizado entre 1991 a 1997 pela Rede de Televisão SBT, eu sentia um grande incomodo no que parece ser faces de uma história única que sempre é contada sobre pessoas da periferia não por acaso, engaiolados em seus rostos e corpos negros. Como um descompasso entre a tela e o cotidiano que vivo enquanto cidadão negro morador de periferia. Não desejo edulcorar a periferia ou representações sobre as pessoas negras, mas ao sempre ver um negão com uma arma na mão em filmes de grande visibilidade como Cidade de Deus ou Tropa de Elite, penso nas inúmeras questões cotidianas que faíscam explosivamente no que tange às relações raciais da nossa sociedade, mas estas mesmas permanecem necessariamente em silêncio. Como não problematizar a relação do bairro da Cidade de Deus com a cidade do Rio de Janeiro em Cidade de Deus? Por que em Antônia necessariamente as quatro moças tentam "vencer na vida" apenas através da música? E se elas disputassem, numa condição pretensa de igualdade, um vestibular numa universidade pública ou uma proposta de emprego numa empresa de tecnologia? E se Heracles, o motoboy negro protagonista de Os 12 Trabalhos tivesse consciência de sua negritude ao perceber 
que a maior parte dos motoboys são negros? E se Turma do Gueto problematizasse sua guinada no retrato digno, positivo e muitas vezes edulcorado da periferia para o retrato de um cotidiano violento de tráfico de drogas e disputas nas áreas de venda de drogas? E se o policial negro ex-protagonista de Tropa de Elite pensasse: "por que eu, um negro, mato mais pessoas negras?". Por que Natália, no seriado de mesmo nome, somente habita estes dois lugares (subúrbio e agência de modelos) como um passe de concessão do olhar do fotógrafo que a elege no significado exótico do corpo negro da moça? Por que Cinco Vezes Favela, Agora por Nós Mesmos é um filme possível de ser realizado quando tutelado por realizadores brancos e, por outro lado, Luciano Vidigal, um cineasta negro que participou do mesmo projeto, não consegue viabilizar seu documentário e outros de seus quando está fora do que significa esta tutela protagonizada por brancos?

É notório um silêncio de nossos confrontos. Fica recorrente que estas pretensas disputas se esvaziam diante do conforto de uma poltrona de cinema em que a tela separa definitivamente os espaços entre a plateia e um Dadinho (Cidade de Deus) que dá tiros na tela. É legal! Dá medo! Mas naquilo em que se afirma como "Tá Tudo Dominado", nós sabemos e temos certezas de quais lugares encontraremos os pretos e os brancos. Sabemos qual será sempre o lugar que Dadinho ocupará no que significa seu corpo e sua cara preta. Dadinho não faz parte da gente, mas sim de um problema social numa nação que ainda busca modelos para se civilizar. Assim, este perigoso problema deve ser enjaulado para que possamos assisti-lo no zoológico da nossa ideologia. Trazendo assim a sensação que a violência deste olhar é causada por este espaço e não pela relação que resulta neste aprisionamento. 
Naquilo que significa o negro na nossa sociedade, o que é efetivamente representado? E o que se faz nesta representação? Quais aprisionamentos são legitimados? Neste sentido, retornando a Achille Mbembe no texto "As Formas Africanas de Auto-Inscrição", há uma interessante reflexão acerca das diferentes formas com as quais se tentou construir e representar a identidade africana sem que especificidades culturais, políticas e geográficas deste continente sejam consideradas:

"Tentativas de definir a identidade africana de forma simples e clara têm ao longo do tempo geralmente falhado. Outras tentativas parecem estar tendo o mesmo fim, já que a crítica das imaginações africanas sobre o self e o mundo permanece presa dentro de uma concepção de tempo como espaço e de identidade como geografia...

\section{(...)}

...Para ser exato, não há nenhuma identidade africana que possa ser designada por um único termo, ou que possa ser nomeada por uma única palavra; ou que possa ser subsumida a uma única categoria. $A$ identidade africana não existe como substância. Ela é constituída, de variantes formas, através de uma série de práticas, notavelmente as práticas do self.. Tampouco as formas desta identidade e seus idiomas são sempre idênticos. E tais formas e idiomas são móveis, reversíveis, e instáveis. Isto posto, elas não podem ser reduzidas a uma ordem puramente biológica baseada no sangue, na raça ou na geografia. Nem podem se reduzir à tradição, na medida em que o significado desta última está constantemente mudando." (Mbembe, 2001, p.198-199)

O ponto de vista de Achille Mbembe pode ser relacionado ao retrato que produções audiovisuais de maior visibilidade realizaram para espaços e pessoas na periferia. Apesar dos espaços periféricos terem suas semelhanças e especificidades, a periferia aparece em obras como Cidade de Deus e O Invasor (2001, Beto Brant) (como na sequencia em que a personagem interpretada pela atriz loira Mariana Ximenes permanece num boteco do bairro periférico da Brasilândia e os negros do 
local são representados como bandidos que a desejam) através de contornos únicos e recorrentes. Na periferia, frequentemente seus personagens negros são brutalizados, vitimizados e/ou encerrados numa violência pela qual se nasce não obstante da própria pessoa enclausurada em sua periferia ou então nas práticas sociais cotidianas deste lugar. Reitero, o espaço da periferia se faz e é importante que ele exista na nossa sociedade como forma de manutenção destes lugares. Nestas produções audiovisuais citadas, por exemplo, oferece-se a sensação que somente neste lugar se cria e se desenvolve os "monstros" do embate da nossa desigualdade social, a priori. A questão racial fica como produto da nossa desigualdade e não como caráter fundante dela. Nas representações destas obras audiovisuais, seus protagonistas são o "Outro" para o espectador e não necessariamente será personagem com o qual o espectador se identificará. Este "Outro" representado é necessariamente negro. O "Eu" representado dentro de um espelho narcísico tem significado branco na branquitude, como normativo. Isto é uma forma muito confortável e cordial $^{15}$ para sempre se manter a distância que demarca a fronteira da barbárie e civilização através do corpo e do rosto negro. Para tanto, quais são os desafios para enfrentar as estratégias desta ideário?

\subsection{0 que é possível construir.}

Com as 'antenas ligadas' na explosão de produtos audiovisuais que

15 Na obra "Raízes do Brasil", Sérgio Buarque de Holanda destrincha as causas do que ele denominou como "cordialidade" e o "homem cordial". "Cordial" tem sua raiz na palavra latina "cordis" que significa coração. Assim, o homem cordial não significa uma pessoa gentil a priori, mas sim aquele que age movido pela emoção em detrimento da razão. Segundo o autor, o homem cordial não vê distinção entre o privado e o público, detesta formalidades, põe de lado a ética e a civilidade. A partir deste contexto, Sérgio Buarque explica como esta cordialidade define o perfil psicossociológico do povo brasileiro e contribui para todas as mazelas que conviveram e ainda convivem com as relações sociais no Brasil. 
retrataram a periferia; roteirizei duas propostas audiovisuais em formato de série televisiva: "Menina Mulher da Pele Preta", série de cinco capítulos com cinco histórias diferentes de cinco mulheres negras de vários perfis de idade e de condição social, da qual o média metragem Jennifer é o capítulo piloto e a série "Sociedade Anônima", com doze capítulos e que traz a trajetória de Rodrigo, um motoboy negro morador da Vila Nova Cachoeirinha que estuda numa faculdade pública de Arquitetura e Urbanismo. "Menina Mulher da Pele Preta" pode ser um longa-metragem em formato de telefilme ou uma série televisiva sem que necessariamente haja mudanças em sua dramaturgia. Já "Sociedade Anônima" foi concebida como uma série televisiva de fato, não havendo intercambialidade como filme.

Apesar da série televisiva "Sociedade Anônima" ter sido a primeira proposta audiovisual defendida neste mestrado; por uma questão de foco, a partir da qualificação optou-se desenvolver a série "Menina Mulher da Pele Preta". Mantenho aqui o desenvolvimento das referencias que consolidaram a série Sociedade Anônima, ou seja, a análise da representação do negro e da negra nas produções audiovisuais que retrataram espaços periféricos e a interlocução disso no ambiente universitário. Elas permaneceram na medida em que elas também balizam a discussão que faz gerar "Menina Mulher da Pele Preta". Para o projeto "Sociedade Anônima", protagonizado por um motoboy negro que vai estudar arquitetura na FAUUSP, permanece sua construção no horizonte muito próximo.

Ao apresentar "Menina Mulher da Pele Preta", eu proponho uma dramaturgia audiovisual que dialoga com a representação da pessoa negra em nossa sociedade. 
$\mathrm{Na}$ série, a ideia é problematizar pesquisar e propõr formas alternativas aos estereótipos. Assim, nos roteiros, o intuito é desenvolver personalidades e situações concretas, criando para isto personagens com profundidade e personalidade própria. Personagens que vivem, por exemplo, em comunidades na periferia da cidade de São Paulo, mas que não se resumem a essa condição geográfica e de classe. As protagonistas de "Menina Mulher da Pele Preta" são personagens que enfrentam tensões evocadas em universalidade diante de sua condição de classe e de raça.

Tendo em vista a produção e a realização audiovisual desta série televisiva, esta dissertação descreve os elementos dramatúrgicos estruturantes de cada episódio; ou seja, a elaboração do universo de significados que os episódios da série abordam, das razões em que eles se constroem, do recorte realizado através dos(as) personagens criados(as) e dos espaços em que eles(as) são retratadas. Até o momento de qualificação desta dissertação, eu defendia a série "Sociedade Anônima" e para ela, eu descrevia estruturas intrínsecas dramatúrgicas, correlacionando assim a diversos autores (geralmente norte-americanos) que analisam narrativas de roteiros cinematográficos oriundos de filmes dos Estados Unidos. Após a passagem pela banca de qualificação, a indicação de seus integrantes e da orientação nesta pesquisa foi aprofundar o caráter pessoal no projeto. Para tanto foquei a elaboração de uma dissertação com caráter autoral e ensaístico no qual eu pudesse me relacionar entre a dramaturgia proposta e a problematização daquilo que faz gerar "Menina Mulher da Pele Preta" (que até então era um compêndio dos roteiros "Jennifer...", "Larissa S/A" e "Simone - Estórias em Estação de Transferência", colocados como produção acadêmica paralela, mas correlacionada ao mestrado). Penso assim responder a recomendação da banca de 
qualificação que sugeriu o fortalecimento da componente pessoal deste trabalho.

"Menina Mulher da Pele Preta" traz cinco histórias independentes entre si de cinco mulheres negras de diferentes idades e contextos; nisto, as próprias histórias internas desta série têm suas diferenças nas estruturas dramatúrgicas. A saber, o episódio "Dara - A Primeira Vez que fui ao céu" dialoga com a cinematografia iraniana, tendo em vista aqui realizações de cineastas iranianos como Jafar Panahi, Abbas Kiarostami e Mohsen Makhmalbaf. O episódio "Deolinda" tem inspiração nos filmes A Igualdade é Branca (1994), A Fraternidade é Vermelha (1994), Não Matarás (1988) e o primeiro episódio da série televisiva polonesa Dekalog denominado Amarás Deus acima de todas as coisas (1988), todos realizados pelo cineasta polonês Krzysztof Kiéslowski; a opção em se referir as obras deste cineasta se dá pela presença nelas de desconstruções sobre papéis exercidos pelos personagens. Em A Fraternidade é Vermelha, o personagem juiz aposentado narra um julgamento de um réu no qual indiretamente sua história de vida estava interligada a do próprio juiz, fato que fere o princípio de imparcialidade no julgamento. Em A lgualdade é Branca, o cabeleireiro Karol Karol questiona o princípio de igualdade na côrte francesa uma vez que ele (acusado de não consumar o casamento) não é francês e sim polonês. De maneira geral, a referência para "Menina Mulher da Pele Preta" é a série televisiva O Decálogo, esta série polonesa tem sua unidade temática através de dez histórias diferentes que dialogam com os Dez Mandamentos Bíblicos do Velho Testamento. Kiéslowski elaborou unidades formais nesta série; todas as histórias se passavam com habitantes num conjunto habitacional de Varsóvia. A fotografia cinematográfica é relativamente semelhante em quase todos os episódios e em todos eles há um personagem misterioso, não um narrador, mas um 
observador que aparece em todos os capítulos.

A unidade da série "Menina Mulher da Pele Preta" gira em torno de um elemento comum: O Protagonismo da Mulher Negra. Dialogando assim com a diversidade de retratos destas mulheres protagonistas, a série não segue formalmente uma unidade espacial e fotográfica em seus cinco capítulos. Ao propor estas dramaturgias, contextualizo o ponto de vista que construo para realizar esta dissertação. Creio que seja necessário colocar algumas bases em que me apoio para construir esta proposta que surge através de minhas inúmeras indagações (e indignações também) a propósito de como o universo da periferia, o negro e a negra são representados no cinema e na televisão brasileira. Criticar as produções audiovisuais elencadas anteriormente não representa um ato de desprestígio e desconsideração da importância destas obras, pelo contrário. O que desejo é trabalhar maiores diversidades nas interlocuções audiovisuais que discutam nossas questões raciais. Neste sentido, não desejo trazer "O" modelo audiovisual que funcione e, assim, desprezar todos os modelos anteriores. Não é este o objetivo. Analisar as obras que retrataram espaços periféricos e protagonismos negros é uma tentativa de compreender como a temática de representar o negro e a negra no nosso audiovisual obedece certas invisibilidades independente de retratos positivos ou negativos. Assim, num ato de se libertar dos "grilhões" da branquitude, eu apenas tento exercer o direito de ser mais um no nosso cenário audiovisual com toda dignidade que exerço em minha cultura e identidade. 


\subsection{Audiovisual, Negro, Expressão, Representação, Universidade Pública e Periferia. Problematizando a relação entre elas.}

Quando retro-escavadeiras não podem mais derrubar paredes e pilares ou restos delas, lança-se mão de tratores britadeiras e britadeiras de mão. Esta etapa da demolição, metaforicamente, traz muito mais trabalho que, por ser manual, exige ser mais esmiuçado.

O período de grandes visibilidades audiovisuais para espaços periféricos ocorreu, em grande parte, concomitantemente a minha graduação em audiovisual na ECA/USP (2002 a 2007). Na academia, como graduando em cinema, rádio e TV, eu refleti quais seriam e são minhas responsabilidades enquanto negro morador de periferia e universitário que está num curso que constrói e/ou que reitera significados audiovisuais. Ao olhar em volta numa universidade pública como a USP, percebi que em seu cotidiano há poucos negros e negras no corpo discente e docente. Lá, o normativo compreende que esta falta se dá por um problema social que, no fundo, reflete uma inadequação civilizatória ou 'um algo-branco-que-nuncairei-ser', principalmente quando se retrata periferia em seu corpo e rosto negros.

Na minha turma de audiovisual haviam mais duas garotas negras que não se viam como negras numa universidade pública com poucos negros, especialmente em cursos elitizados como do bacharelado em audiovisual na ECA/USP; para tanto, não problematizavam isto. Compreendo que elas não são e não estavam obrigadas a levantar bandeiras de negritude por mais que se possa reconhecer suas conquistas sendo mulheres negras no audiovisual. No entanto, sinto que se elas 
tecessem visões críticas a significados em suas diversas passagens, isto acarretaria perdas em relação a amizades, sociabilidades construídas, além de oportunidades na carreira se pensarmos de maneira bem objetiva o mundo do trabalho no audiovisual. Apontar estas possibilidades vêm num sentido de enxergar possíveis recorrências ao negro que questiona seu lugar numa universidade. Eu me pergunto se ao realizar tais questionamentos o negro é frequentemente rotulado como ressentido de nossas relações raciais.

No universo acadêmico do Bacharelado em Audiovisual, por mais que lá eu tenha negociado ser branco e ser negro, para mim ficou a experiência que uma universidade pública como a USP acaba atuando como instrumento eficiente na experiência de exclusão mesmo numa condição de pretensa igualdade. É uma exclusão de possíveis histórias negras na universidade por mais que existam iniciativas dentro dela (como em matérias e pesquisas realizadas na Faculdade de Filosofia, Letras e Ciências Humanas da USP e na Escola de Comunicações e Artes) para se trabalhar e compreender tais relações raciais em nossa sociedade. Mas falar sobre negro, problematizar periferia sob o rosto negro em discussões que ocorrem numa universidade pública como a USP é diferente de ser negro e negra neste mesmo ambiente universitário. Quando digo "SER", não se trata de desejar o lugar de objeto para discussão, mas este "SER" significa ser agente e protagonista em suas identidades negras das relações que se tecem num ambiente acadêmico elitizado.

Em Fevereiro de 2010, segundo ano de meu mestrado, eu re-encontrei meu professor em graduação, o Professor Doutor Mauro Wilton. Com Mauro, eu tive 
aulas em Metodologia de Pesquisa e em Teoria da Comunicação. Hoje, ele é Diretor da faculdade onde eu estudei e estudo atualmente... Afinal voltei a Escola de Comunicações e Artes da Universidade de São Paulo (ECA/USP) para realizar meu mestrado em Ciências da Comunicação. Professor Mauro, sempre gente boa (crivo meu), indagou-me sobre qual tema que trabalho no mestrado. Eu lhe disse que construía estrutura e roteiros de uma série televisiva que discute a presença do jovem negro de periferia na universidade pública. Mauro sorriu e ele, ao relembrar de algumas inquietações minhas durante a graduação, disse-me que "Este tema te pegou mesmo!". Ao responder, retribuindo a camaradagem, eu the disse que esse tema não me pegou, mas nasci nele e não obstante gostaria de apresentá-lo aqui na Escola de Comunicações e Artes da Universidade de São Paulo.

A série que delineei em aspectos gerais para Mauro Wilton é "Sociedade Anônima". Ela traz a história de Rodrigo, um jovem negro motoboy morador do bairro periférico da Vila Nova Cachoeirinha e que estuda Arquitetura e Urbanismo numa universidade pública. Ao enxergar minha própria jornada na USP e tentar problematizar a pessoa negra neste lugar universitário, percebi que o desafio está em compreender e discutir as relações que se estabelecem na faculdade quando quem as protagoniza é uma pessoa negra.

Não se trata de ressentimento. Aliás acredito que esta palavra tem sido utilizada para não se questionar muitas vezes algumas comodidades e alguns confortos nos quais os embates daquilo que significa branco e negro em nossa sociedade sejam encarados. Para tanto, como um operário numa britadeira, o que exponho a seguir é uma segunda fase de demolição que perpassará o espaço 
universitário e retirará entulhos sobre significados de uma jornada negra e periférica numa universidade pública.

Antes de estudar na USP, eu não tinha ideia que a prática da convivência numa faculdade como esta seria tão elitizada, aristocrática e embranquecedora. Reitero. Esta provocação não é ressentimento ou algum outro adjetivo que tergiverse a problemática ou mesmo uma injustiça com um espaço universitário como a USP; que, de alguma forma, contempla em cursos da Faculdade de Filosofia, Letras e Ciências Humanas - FFLCH/USP possibilidades em discussões acerca do negro na universidade. Mas discutir é diferente de ser.

Eu sempre morei na Vila Nova Cachoeirinha, conhecida como periferia da Zona Norte da cidade de São Paulo. Lembro de minha mãe quando dava referência aos meus parentes de Pernambuco ou mesmo daqueles que moram noutro bairro periférico de Ermelino Matarazzo, Zona Leste da Cidade de São Paulo... Lembro que a melhor indicação para se dar era que o bairro onde eu moro pertencia a Santana. Eu achava estranho, Santana fica a $7 \mathrm{~km}$ de onde eu moro, já o Largo Japonês, na Vila Nova Cachoeirinha, fica na mesma avenida do meu bairro.

Santana é um bairro de classe média alta aqui da Zona Norte de São Paulo, até hoje é um bairro muito conservador, bairro de imigrantes europeus que se destacaram como classe média e média alta. É um bairro majoritariamente branco com boas escolas particulares, boas casas e acesso ao metrô. O que isto significaria nesta minha jornada escolar até chegar a universidade? O que faz uma família esconder que mora na periferia?.. O que faz uma pessoa evocar o antepassado 
branco para lhe conferir alguma civilidade?.. O que faz uma pessoa não sentir amor a uma pessoa negra, mesmo não sendo branco?.. Ascensão? O normal, mesmo não verbalizado, parece ser sempre o Negar... Negação. Imagino aqui quantas pessoas da época afirmaram que moravam na Penha, escondendo a Vila Guilhermina, Cohab José Bonifácio, Itaquera... ou aquelas que escondiam o Jardim Jacira afirmando sua morada no bairro de Santo Amaro. Negociando negações...

Eu cresci tendo a referência que para me tornar alguém "de bem" eu deveria necessariamente estudar numa escola afastada do bairro onde eu moro. As escolas públicas aqui do bairro eram muito complicadas com 'Molecadas sem noção' e professores desmotivados. O fato principal era que, tanto na TV quanto no "disseque-disse" do bairro, escolas públicas vizinhas a minha casa como a "E.E Guilherme de Almeida" ou a "E.E Antônio José Leite" eram verdadeiros caos permeados de maconha, cocaína, traficantes, acerto de contas e assassinatos. Lembro que no telejornal Aqui Agora, do SBT, era frequente associar a Escola Pública com imagens de crianças negras, lembro das imagens delas... Vem-me a memória crianças famintas de merenda e sujas de catarro na tela da TV... fechadas necessariamente como protagonistas de um circo dos horrores ou de um zoológico periférico em que a atração principal tinha necessariamente a pele preta.

Em 1993, a reportagem do telejornal Aqui Agora veio na escola pública estadual onde eu estudei meu sexto ano do fundamental. Naquela época, havia um maníaco. Diziam que ele injetava material sanguíneo nas crianças para inoculá-las o vírus do HIV. No retrato falado que apareceu na TV, adivinham! Um preto! Nome? Não tinha nome. Seu Apelido era Fumaça! Acha estranho? Creio que não. Cidade 
dos Homens tinha seus garotos protagonistas com apelidos de frutas, talvez na nossa história seja normal ao preto ter apelido como nome. O tal "Fumaça" apareceu na televisão e desmentiu tudo, apanhou da polícia na sua convicção que não era o maníaco (ao apanhar, será que ele não se perguntou se era o tal maníaco mesmo?), a história foi criada pelos alunos e tomou a sensacional e espetacular proporção telejornalística.

Imagine você neste contexto? Todo dia a imagem de quem é parecido com você, a imagem daquilo que você gosta (uma roda de samba, por exemplo) ou a imagem de quem poderia ser seu parente ou mesmo você estarem todo dia associados a um problema social em que a maior ação disto é retratar a diferença como se fosse um mal a ser extirpado ou enjaulado para se marcar a impossibilidade na diferença? Você que lê este texto, sentiria o que diante do espelho? Que é negro? Ou iria negociar o mais longínquo branco para lhe dar status de dignidade e civilidade? Que vínculos você conseguiria ao se considerar essencialmente negro ou dizer que ser negro faz parte da sua vida pública? Ser suspeito? Cadeia? Uma sociedade que até na Universidade Pública seu elitismo pode Ihe render sutis e constrangedores impedimentos?

Eu não me identificaria com isto! Em nome do meu futuro, faria como o jogador de futebol Neymar do Time 2010-2011 do Santos Futebol Clube. Digo que nunca sofri preconceitos porque não sou negro! Mesmo que me atirassem uma banana em campo, diria que sou filho da mestiçagem e que estão me confundindo. Aquilo que significava branco em mim fazia muito sentido para poder me ascender, educacionalmente inclusive. A mestiçagem é o indicativo que o racismo não existe 
em nosso país; no entanto, para conviver na batalha por crescer e pertencer na vida, eu negociava o que de branco havia em mim. Como um boleiro no gramado da sociedade, eu procurava jogar com a norma branca social para me compreender como possível nela.

"O discurso do branqueamento estava atrelado às ideias de assimilação. Em outro artigo, "Assimilação dos imigrantes no Brasil: inconstâncias de um conceito problemático", Giralda Seyferth (2000) argumentou que tal processo fez parte dos projetos nacionais que ansiavam em construir uma sociedade em que predominasse 0 "abrasileiramento" com a integração de elementos nacionais e estrangeiros. Afirmou que a construção do "tipo nacional" só seria possível se os imigrantes europeus trazidos para o Brasil fossem capazes de "civilizar" os indivíduos potencialmente inferiores sem, contudo, descaracterizar a base já estabelecida, como a língua portuguesa e a "cultura latina". Portanto, esta política exigiu, conforme diz Giralda Seyferth, a "assimilação e [o] caldeamento ou miscigenação dos imigrantes" (1996:49) para a constituição dos elementos que deveriam constar deste "tipo nacional": branco, eficiente e difusor dos valores positivos da cultura brasileira. Porém, a autora ressalta que eram os elementos culturais nacionais que precisariam ser seguidos. Dessa forma, esses imigrantes teriam que passar por um processo de "aculturação", assim como a população mestiça e negra considerada não-apta aos padrões de desenvolvimento apregoados naquele momento. (Silva, 2008, p. 61)

Ao fundamentar sua tese de doutorado Pelé e o complexo do vira-lata, a antropóloga Ana Paula da Silva resume as argumentações da antropóloga Giralda Seyferth apontando para um ideário de branqueamento civilizatório no final do século XIX e no início do século XX que validou, dentre outras ações, o processo de imigração neste período. Partindo deste contexto, Ana Paula elabora em sua tese que nesta época o Futebol foi um elemento de subversão a uma ordem branqueadora e também higienista. Este esporte também era uma prática que poderia fornecer um ideal de corpo são (dentre vários outros esportes que poderiam oferecer a o resultado de corpo sadio). Estas ideias foram frequentes neste período 
e estavam absorvidas como uma das diversas apropriações sobre o conceito de seleção natural biológica elaborada por Charles Darwin. Um corpo sadio é um lugar preenchido onde as doenças, muitas vezes associadas a pessoas ou comunidades que denotavam degeneração, não têm espaço. Naquela época, preferencialmente o branco europeu seria o corpo e o rosto protagonista a exercer estas atividades esportivas sadias; no entanto, o futebol se tornou um esporte no qual (em alguns clubes como Ponte Preta, Internacional de Porto Alegre, Grêmio Rio Grande, entre outros) o negro também pôde exercer suas habilidades em campo, uma vez que o futebol laureia democraticamente aqueles que têm e que utilizam os melhores fundamentos deste esporte dentro das quatro linhas do gramado. Paralelamente a este contexto, o futebol já mobilizava grandes torcidas independentemente de classe social ou de raça; no entanto, Ana Paula destaca que esta presença possível não foi um arrefecimento das tensões raciais naquilo que significa o branco e o negro nela, tanto que as torcidas não eram o lugar efetivo ao encontro desses diversos atores sociais (no começo do século $\mathrm{XX}$, o Fluminense não aceitava negros na arquibancada de seu estádio, por exemplo). O que o futebol proporcionou como encontro desses diversos atores sociais foi o reconhecimento do exercício das habilidades possíveis no gramado. Para o antropólogo Roberto da Matta, o futebol é um palco onde se vivencia efetivamente a democracia no Brasil ao contrário de seu cotidiano social, pois neste esporte as regras são simples e abrange a todos sem distinção. Segundo o antropólogo, o próprio ingresso neste esporte é conferido efetivamente àqueles que tenham habilidade em seus fundamentos e no futebol o que vale é o mérito, ao contrário do que ocorre em nossa sociedade na qual as regras de convívio no espaço particular da Casa Grande é ampliada para as relações das práticas exercidas em espaço público. 
De maneira análoga, o processo vestibular para cursar o ensino superior é também um lugar ou um sistema no qual o ingresso é conferido àqueles que demonstrem seus conhecimentos nas mais diversos fundamentos nas áreas exatas, biológicas e humanas. Assim como no futebol, o que vale para o ingresso numa universidade é o mérito. No nosso país, geralmente os melhores do processo vestibular conseguem estudar numa universidade pública ou então em particulares renomadas como PUC, Gama Filho, FEl, entre outras. Neste contexto, para que eu crescesse sendo uma "pessoa de bem", meus pais operários batalharam muito para que eu e meus irmãos (irmã e irmão) estudassem em colégios particulares próximos do bairro onde moro. Ao contrário da geração dos meus pais, na minha geração a escola particular era a melhor escolha para quem quisesse ou pudesse oferecer a melhor educação para seus filhos. Meus pais não estudaram muito tempo na escola, meu pai fez ensino profissionalizante no SENAI (algo semelhante a terminar a oitava série aliado a um curso técnico) e minha mãe estudou um ano no período noturno de uma escola pública no bairro da Penha. Ela se alfabetizou no programa de alfabetização dos anos 60 e 70 conhecido como MOBRAL (Movimento Brasileiro de Alfabetização). Suas demandas como filhos de migrantes nordestinos foram prioritariamente o estabelecimento nesta terra paulistana e assim cumprir a meta daqueles que saíram de terras pernambucanas para serem capazes em outras paragens. $O$ trabalho remunerado foi a melhor escolha dentre as possíveis para se estabelecer aqui, ainda mais num período como o início da década de 70 no qual o Brasil crescia economicamente de maneira forte. Acredito que ao trabalharem, meus pais perceberam que as pessoas com melhores salários e aquelas que estavam hierarquicamente acima deles eram necessariamente pessoas com diploma 
universitário. Talvez este fato e também a escolha do trabalho em detrimento ao estudo fizeram com que meus pais elegessem para seus descendentes (meu caso) que os estudos possibilitam maiores e melhores escolhas na vida naquilo em que gostaríamos e estivéssemos aptos a fazer. Desta forma, estudar numa faculdade ou numa universidade sempre esteve em nossos horizontes enquanto descendentes de uma família de migrantes pernambucanos aqui em São Paulo.

Assim, eu estudei em duas escolas particulares até meu quinto ano do fundamental, uma no bairro do Mandaqui e outra no bairro do Imirim. Eram escolas particulares, caras conforme a inflação do mês, mas eram limitadas. Dignas para que meus pais operários pudessem pagar as mensalidades. Sempre me destaquei nas notas, nas avaliações e eu me sentia o mais inteligente da turma. Lembro que na particular do Mandaqui, os outros alunos sempre me perguntavam se eu era filho da faxineira. A Faxineira é Maria das Dores, amiga de infância da minha mãe que também é pernambucana e negra. Minha presença lá na escola não estava numa condição igualitária de quem também tem acesso pago a uma boa educação. Meu corpo e meu rosto significavam algo: um acesso de concessão ou como bolsa de estudos ao filho da faxineira. Nesta ideia, havia uma justificativa plausível para manter certas distâncias. Estar em igualdade com os outros alunos traz certas dificuldades. Se eu ia bem nas notas, era importante me deslocar deste lugar para que, no máximo, algum professor achar digno o esforço de quem parte muito mais "do zero". Quando não, eu era motivo de chacotas da garotada... Talvez exerciam ali, sem se darem conta, da nossa herança ideológica apartadora e normativa.

Importante destacar que ao me colocar em relação a estas lembranças, eu 
não tenho a perspectiva de remoer o que poderia ser diferente na minha história de vida; pelo contrário, esta história também me formou naquilo que exerço hoje. Por outro lado, ao enxergar os caminhos trilhados, eu me pergunto sobre a atualidade dessa nossa ideologia. Embranquecedora? Elitista? Aristocrática? Talvez elas estejam entrelaçadas. Nesta mistura, fica uma sensação de estar em igualdade, mas sarcasticamente a todo momento não estar nela. Necessariamente esta misturacentrífuga decanta duas fases: algo que denota conforto para quem exerce o desejo da distância e outro algo que denota enclausuramento naqueles em que a ideologia é exercida. Talvez os conceitos de embranquecimento, elitismo e aristocracia operam entre si mutuamente; nisto um sentimento que remete a "Vencer na Vida" não arrefece tensões sobre o que representa/significa o negro e o branco em nossa sociedade, pelo contrário. Vencer pode significar o laureado branco que o negro conseguiu negociar.

É interessante compreender como identidades, branquitude, estereótipos e invisibilidades atuam num jogo entrelaçado. Digo isto porque aprendi que a face na discriminação ao negro não é, todas as vezes, verbalizada e operada pelo outro, o discriminador. Esta aí uma das ingenuidades. É muito dolorido perceber em si mesmo como o desejo de ascensão na vida (refletido através de uma batalha por uma trajetória educacional digna, por exemplo) está intimamente relacionado a uma postura de se negar ser negro. Este olhar embranquecedor que nega inclusive possíveis relações com outras pessoas negras que, num momento da vida, estavam junto nos estudos, na mesma escola, no mesmo bairro.

Uma garota negra estudou comigo no quinto ano do fundamental (1992), meu 
último ano em escola particular. Ela se chama Daniela Tavares e mora num bairro ao lado do meu. Atualmente somos amigos, ela se lembra de mim na escola e na mesma turma em que estudávamos, inclusive ela tem fotos da turma em que eu estou; no entanto, eu não me recordo em nenhum grau de lembrança da presença dela na minha turma de escola. Por que Daniela me foi tão invisível na escola? Acredito que havia definido inconscientemente meu futuro já naquela época. Para trilhar um bom caminho enquanto cidadão pertencente a educação, a bons estudos, a um caminho de ascensão, aprendi a não enxergar possibilidade em amar uma garota negra. Aliás, parece que, muitas vezes, amar uma pessoa negra representa final de escolha ou quando já não há mais nada a escolher. Lembro que amava platonicamente uma garota branca... Não a ela em si, mas o que esta garota significava... E, realmente, até chegar a faculdade, lembro de só haver gostado praticamente mulheres brancas, ou então loiras.

O Negro no mundo dos Brancos... Como projeto de nação, do negro se foge. Pardo, marrom, moreno, queimadinho são olhares embranquecedores que atuam como carimbos de passaporte para que você, negro, tenha alguns trânsitos maiores. MAS NÃO ESQUEÇA SEU CRACHÁ ${ }^{16}$ !

O devir, a ascensão, o retrato do amor talvez ainda estejam num rosto branco europeu. O embranquecimento se assemelha a algo normativo, talvez seja uma face da branquitude. Se isto fosse somente comigo, mas não é. Lembrei de Florestan:

16 Na obra "Negros na Universidade", a antropóloga Moema de Poli Teixeira colhe depoimentos de graduandos negros e comenta sobre a frequente necessidade destas pessoas negras terem ou precisarem utilizar um crachá para circular de maneira mais tranquila por um território universitário no qual não é comum o rosto e o corpo negros. 
"a integração à ordem social competitiva depende de certos prérequisitos. O negro e o mulato precisam deixar de conceber-se, psicológica e socialmente, à luz da imagem do 'negro' construída no passado recente. Ou fazem isso e disputam as oportunidades de classificação e de ascensão existentes, ou continuam à margem do fluxo da vida social organizada e de seus proventos econômicos, políticos e morais (...) O 'negro' tem de decidir entre a exclusão consentida e a participação imposta." (Fernandes, 1972. p.194)

Minha jornada foi batalhar para estudar em escolas melhores. Em 1996, eu entrei em $2^{\circ}$ colocado no vestibular do curso técnico em Telecomunicações na Escola Técnica Federal de São Paulo - ETFSP (atual Instituto Federal de Educação Tecnológica de São Paulo - IFET/SP). O processo de entrada na Escola Técnica Federal de São Paulo é (e sempre foi) através de um processo vestibular bem rigoroso e com uma relação de candidatos por vaga bem alta. Apesar da ETFSP, atual IFET/SP, ser uma escola pública, seu cotidiano é completamente diferente de uma escola pública por exemplo do bairro onde eu moro; os alunos da ETFSP eram, na imensa maioria, oriundos de classe média e média-alta. Mas mesmo tendo esse viés, sempre tem algum preto que escapa das estatísticas.

O Curso Técnico em Telecomunicações tinha a entrada 72 alunos por ano, 36 no horário matutino e o restante no vespertino. Somados os 4 anos do curso, convivi ali com pelo menos 288 alunos da área de telecomunicações. Deste total, eu lembro de cinco alunos negros: Benedito, Eu, e Marcos (turma da manhã); Juliana e Eula (turma da tarde). Excetuando Marcos, todos nós entramos em 1996. Pela divisão de horários e de turma, eu convivi bastante com meu amigo Benedito. Eu tinha 15 anos quando entrei nesta escola e Benedito já tinha 22 anos. Benedito é baiano de Porto Seguro e tardiamente conseguiu oportunidades de trabalho e de estudo em São Paulo através de seu pai de santo Júlio (um senhor branco) que tem um terreiro de 
candomblé no bairro do Imirim. Ele dividia seus estudos com seu trabalho nesse terreiro no qual era Ogã ${ }^{17}$ e realizava serviços gerais; para isto, Benedito ganhava um salário mínimo. Marcos era repetente, ele entrou no curso em 1995, no ano seguinte ele reprovou novamente e foi expulso da escola, ele morava em Itaquera, seu pai era policial militar que morreu em serviço no ano de 1994. Eula teve uma trajetória semelhante a minha, nós fizemos um cursinho preparatório em 1995 na própria ETFSP, mas não éramos próximos. Tanto eu quanto ela nos evitávamos, não por questões de afinidade, mas havia algo de estranho caso nós dois estivéssemos mais juntos. Creio que para nós tenha sido receio de perder algumas amizades já conquistadas. Eula morava no bairro da Penha, ela era de classe média e estudou numa escola particular da Penha chamada OPEC. Juliana era uma aluna muito tímida, tanto que só fui conhecê-la quando disputei uma vaga estágio na Embratel em 1999. Juliana era pobre e morava no bairro periférico do Jardim Brasil, zona norte de São Paulo.

Nos anos de 1998 e 1999, diferentemente dos colegas de classe média ou média-alta (não por acaso brancos, como resultado); eu, Benedito e Juliana tivemos grandes dificuldades em conquistar estágio. Já Eula não tenho parâmetro, não convivia com ela e não sei como foi sua jornada. Mas diante das privatizações e da demanda em serviços de telecomunicações nesta época, os profissionais desta área eram muito requisitados para implantar centrais Rádio-Base de Celulares, Rotas de Fibra Óptica, Centrais de Trânsito de Dados PDH e SDH, Centrais de Atendimento, entre outros serviços. O curso técnico que realizei tem em seu último e quarto ano a obrigatoriedade de estágio na área; já havia chegado a metade de 1999 e tanto eu, 
quanto Benedito e Juliana não tínhamos conseguido estágios. Ao mesmo tempo, os colegas de turma de classe média e média-alta já miravam o após técnico. Inclusive muitos prosseguiram na carreira e realizaram cursos de engenharia em faculdades como o Instituto Mauá de Engenharia, FEl - Faculdade de Engenharia Industrial, Escola Politécnica da USP. Hoje, muitos deles e delas têm bons cargos em empresas como Avaya, Embratel, Cisco Systems, 3Com, Embraer. Não nego seus esforços em suas trajetórias e em seus conhecimentos; mas naquela época tínhamos basicamente as mesmas formações e as entrevistas de estágio estavam claras. Naquela época, dentro da concorrência dos estágios, eu, Benê e Juliana, estávamos defasados de alguma coisa que era maior que o nosso conhecimento por maior competência que pudéssemos expressar ou mesmo ímpeto em exercer aquilo que aprendemos durante quase quatro anos de ensino técnico.

$\mathrm{Na}$ época, a Embratel mantinha um vínculo com a Escola Técnica para cessão de estagiários. Depois de longa espera ao me inscrever para uma vaga ainda nos idos de 1998 e tentar inúmeras dinâmicas de grupo em outras empresas até então (como a Asea Brown Bovery e o Centro Empresarial São Luiz), em Junho de 1999 consegui meu primeiro estágio na Embratel assim como Benedito e Juliana (quando vim a conhecê-la de fato, Juliana me disse ter sido seu primeiro estágio na área). Benedito foi trabalhar no setor de conexões via satélite; eu e Juliana tínhamos a promessa de programar novas centrais telefônicas DDD e DDI de Transbordo (Discagem Direta a Distância, ligações telefônicas regionais e Discagem Direta Internacional, ligações telefônicas entre países); no entanto, cuidávamos de papeladas burocráticas de mudanças em rotas de Canais Multiplex (Junção Digital de canais de voz) que até hoje eu não entendia qual era o fundamento daquilo uma 
vez que já existia softwares de banco de dados.

$\mathrm{Na}$ mesma grande sala do $6^{\circ}$ andar da Embratel onde eu e Juliana estávamos, haviam dois grandes amigos da escola que (estes sim) programavam centrais de transbordo. Eles foram efetivados na empresa, pois eles se mostravam muito interessados e dispostos a aprender cada vez mais o cotidiano daquele trabalho. Em Agosto de 1999, percebi que não teria como construir algum caminho nesta empresa e realizei entrevistas em outras oportunidades de estágio na área. Saí de lá na metade deste mês e um outro aluno da ETFSP em eletrônica que também se chama Renato entrou no meu lugar. Ele começou trabalhando na mesma papelada burocrática e logo, pelo esforço dele em querer programar centrais telefônicas, ele conquistou outras funções. Passado o período de estágio, Renato foi efetivado na empresa com um bom salário na época. Ele é branco. Juliana trabalhou pouco tempo com este rapaz, ela saiu da Embratel tão logo vencido o contrato de estágio. Terminou como começou, organizando papéis. Ela saiu de lá doente e num processo de depressão, não sabia qual era a causa. Agora faz sentido aquilo que Frantz Fanon desenvolvera em sua obra "Os Condenados da Terra" ao esmiuçar os transtornos mentais decorrentes do processo do neo-colonialismo ocorrido na África.

Como Brasileiros, nós não tivemos e não sofremos um processo neo-colonial e tampouco passamos por um processo de independência como ocorreu com a Argélia nos anos 50 e 60 e em outras colônias africanas. Para tanto, o texto de Fanon em sua obra citada poderia estar datado e justificado apenas nesses lugares nos quais houveram estes processos de independência. No entanto, é possível traçar paralelos interessantes no que se refere a sentidos de inadequação do negro 
ainda levantados, por exemplo, por Florestan Fernandes. Não foi somente Juliana que não foi efetivada no estágio; Benedito também não foi efetivado em seu estágio, não havia proposta para sua efetivação na área de conexões via satélite e nem em alguma outra função. Eu, por exemplo, saí da Embratel para trabalhar numa empresa de menor visibilidade, recebendo menos para estagiar; mas aí sim programando centrais telefônicas de atendimento. Para realizar aquilo que eu estava apto e capaz de fazer, eu tive que ganhar menos. Nós nos acostumamos a ver estatísticas do IBGE que saem em noticiários televisivos e impressos nos quais afirma-se que o negro tem salário menor que o branco e, como trago um caso concreto, é interessante refletir: Para mim, Benedito, Juliana, o fato de entrarmos num curso tão concorrido como Telecomunicações já seria em si uma grande vitória. Por outro lado, o que havia em Renato, meu homônimo do curso de eletrônica, para que ele se tornasse funcionário logo depois de sua entrada como estagiário? Acho que a pergunta fica melhor se refletirmos sobre a troca "do que havia no rapaz" pelo "o que ele significava” enquanto estagiário ávido por conhecimento. Talvez ele não tenha exercido inconscientemente o que a anos; desde sempre, enquanto negros; estamos acostumados a introjetar que é duvidar de nossas possibilidades. Mas tirar esta dúvida não resolveria somente. Meu homônimo teve em seu corpo, em seu rosto e em sua sociabilidade muito daquilo que significa o confortável, o comum e o normal de um ser humano que busca suas oportunidades. Reclamar discriminação ali seria injusto, afinal a empresa deu oportunidade a todos. Meu homônimo percorreu dignamente sua ascensão profissional e colheu os resultados disso. Já Juliana, partindo de um mesmo lugar que era o ensino técnico, implodiu em sua depressão pela qual ela ganhou a sensação de descontrole do próprio corpo. 
Cada degrau da ascensão é uma maratona, quanto mais preto, mais afastado do ponto de partida você partirá. Caberá a você, na relação estabelecida e se ela envolve poder, como você conseguirá negociar o branco que há em você. Ou então negar-se como um preto de alma branca.

$\mathrm{Na}$ metade da década de 1991-2000, minha mãe fazia supletivo nas 'perigosas' escolas públicas do bairro. Através de minha mãe, minha família toda acabou conhecendo um professor negro e sua família. Era o professor Tarcísio, de História. Era a primeira vez que me dava conta que era possível uma família inteiramente negra e uma História Negra, um outro ponto de vista que era até então silenciado. Tarcísio e sua família convidaram a minha família para uma missa católica afro. Os cânticos... "Um abraço negro, um sorriso negro, traz felicidade... Negro sem emprego, fica sem sossego... Negro é a raiz da liberdade!”. Finalmente o começo de um espelho negro que não fosse a miséria, a discriminação, mas sim um tipo de Afirmação. Simples assim! Para mim, uma sensação de alívio com que eu gostava ficou evidente. Eu, que ouvia sempre o programa de Samba do Moisés da Rocha aos domingos, ter frequentado a Escola de Samba Camisa Verde e Branco aos meus 10 e 11 anos, ser descendente de pernambucanos, ter a pele escura, não eram mais motivos de vergonha ou silêncio para mim mesmo.

$\hat{E} !$

Êta mundo véio e bom

Bonito, colorido, boa praça.

Atrás, do lado feio do viver

Há coisas lindas

Pra se ver, quero ver...

(Agepê, 1977, LP Tipo Exportação)

Agora este universo fazia sentido pra mim no lugar em que eu estava na 
periferia. Não necessariamente iria exercê-lo em outros lugares, perder os vínculos sociais pode ser um grande perigo para quem aposta em suas possibilidades econômicas e educacionais. Dentro de algumas regras implícitas na Escola Técnica, eu poderia ser claro como um preto de alma branca, mas na minha casa e onde eu moro, daí sim me sentia mais a vontade em ser preto.

Em 1999, eu me formei técnico em telecomunicações. Por um átimo, quase negligenciei estudar numa faculdade, pois eu pensei em trabalhar, fazer grana. Mas meu irmão (que é bem mais claro do que eu e socialmente é considerado branco) estava na USP, graduação na Poli-Química; isto foi também um incentivo para que fizesse algo que realmente eu goste. Eu imaginava que uma universidade como esta, para se entrar e estudar nela, era necessário somente estudar. Mas mais do que estudar, eu tinha a noção que as famosas e grandiosas escolas particulares apenas treinam a garotada para o vestibulares como a USP. Possivelmente treinam as regras para manutenção do 'status quo'.

Como técnico, percebi que meu diferencial estava em não ser treinado para o vestibular. Pensando hoje, não havia o que treinar e, realmente, para que? Eu não tinha que defender herança elitista nenhuma na universidade pública. Nesta fase já estava trabalhando na NET TV a Cabo, fiquei um ano lá e fui demitido porque a empresa passava por dificuldades. Resolveram demitir os técnicos solteiros (ainda bem que não demitiram os negros, não sobrariam nenhum técnico praticamente). Nesta empresa eu executava reparos em receptores de fibra óptica, cabos coaxiais e amplificadores de sinal em postes de bairros ricos e pobres da Cidade de São Paulo. Concomitantemente ao meu trabalho, eu estudava num cursinho vestibular no 
período noturno. Lembro que nesta empresa havia uma necessidade imensa de se realizar horas-extra por conta da implantação de um sistema de internet que utiliza a plataforma da TV a Cabo. Eu recusava a maioria destas horas-extra por querer me dedicar aos estudos vestibulares. Além disso, as horas-extra pareciam um discurso determinado, fadado a me manter sempre naquele lugar. Inclusive não dizia que prestaria Cinema, mas sim Engenharia. O descrédito para minha dedicação aos estudos vinha justamente daqueles funcionários que estavam num mesmo patamar que eu e dentro da mesma equipe. Sentia-me numa escola preparatória para ideologia de capitão-do-mato e meus estudos para entrar na universidade funcionavam como desculpas para não pegar no pesado do trabalho. Em 2001, em Maio, fui demitido e assim tive mais tempo para estudar e aproveitar o FGTS para pagar o cursinho vestibular. Foi melhor para mim, pois assim, em 2002 passei nos vestibulares da Unicamp, Ufscar, Unesp, Cásper Líbero e USP; escolhi estudar o Curso Superior em Audiovisual na ECA/USP. Esta era a minha primeira opção.

"Aqui mesmo na faculdade, eu nunca mesmo estou integrado realmente a um grupo. Não tenho um grupo assim, porque às vezes, quando eu acho que estou integrado a um grupo de colegas que eu ando, sempre acontece uma situação assim que me vejo de fora, discriminado mesmo (...) São coisas pequenas de pessoas que andam comigo, até não percebem, mas que eu sinto muito. Tipo uma situação, por exemplo, pra ficar mais fácil de entender. Estava no bandejão com meus ex-colegas, aí de repente um amigo nosso não pode sentar à nossa mesa, sentou à mesa de um rapaz negro, de cabelos longos, dread locks. Aí no final do almoço ele chegou pra gente e comentou: pô, se um pedaço daquele cabelo tivesse caído na minha comida, um pedacinho que fosse, eu ia jogar tudo fora (...) Na hora eu fico sem reação, eu fico sem reação, eu fico totalmente sem reação. Fico pensando assim, pô, o que é que eu vou fazer agora? Será que vou embora, deixo eles falando sozinhos? Vou discutir com eles? Eu não sei (...) Porque as pessoas falam com tanta naturalidade, que os caras não percebem o que estão falando (...) Eu fico me questionando assim, pô, se ele acha isso desse rapaz, pô, o que ele acha de mim? Se esse cara for na minha casa, o que ele vai achar da minha família? Dos meus avós? Dos meus irmãos? Fico pensando nessas coisas, mas 
depois me dá uma raiva porque eu não fiz nada. Eu devia ter feito alguma coisa, mas eu não fiz nada".

\section{(Depoimento de Aluno de Arquitetura da UFRJ para pesquisa em doutoramento da antropóloga Moema de Poli Teixeira).}

(Teixeira, p.155-156)

Compartilho desta sensação de "Não Lugar" na USP e principalmente no curso em que me graduei. É um descompasso entre aquilo que faz sentido para si e aquilo que você deve aprender. As referências de origem popular, de origem negra, aquelas que fazem parte da minha vida, de homem negro morador de periferia paulistana, têm grandes dificuldades em fazer parte do cotidiano acadêmico ou mesmo do departamento de Cinema, Rádio e TV onde eu estudo na Escola de Comunicações e Artes. Repito, não como assunto, mas como pessoa que exerce este conhecimento para aprender ainda mais na universidade.

"Sonhei ser cineasta pra re-escrever todo o roteiro" (Rocha, poeta da Cooperifa).

Tudo começou bem no curso de audiovisual. Cordialidades entre os alunos. Haviam três alunos negros (eu e mais duas alunas) na turma, contrariando as estatísticas e indicando que a USP não seria tão segregadora assim. O conforto das relações exercia seu poder dentro da pretensa normalidade. Começamos a graduação com diversas matérias. Lembro que assistimos com muita naturalidade ao filme O Nascimento de uma Nação, (1913, D.W. Griffith), esta obra é um exemplo do nascimento de uma linguagem cinematográfica, foi o que se disse em aula. E é de fato. Mas e o sub-texto no qual o filme funciona como uma ode ao movimento racista klu-klux-klan? Deixe que o Spike Lee discuta. Nós brasileiros já resolvemos nossas questões raciais. Misturamos tudo e não dá para identificar quem é quem no 
exercício da nossa ideologia.

Nenhum fervor desconstrucionista deve nos fazer renunciar ao direito de achar que certos filmes são falsos sociologicamente e perniciosos ideologicamente, e de ver "O Nascimento de uma Nação", por exemplo, de ver um filme objetivamente racista. O fato de que filmes são representações não nos impede de ter efeitos reais sobre o mundo: filmes racistas podem ganhar adeptos para a klu-klux-klan ou preparar o terreno para políticas sociais retrógradas. Como assinala Stuart Hall, reconhecer a inevitabilidade da representação não significa que "não há nada em jogo". (Shohat e Stam, 2006, p. 262).

Este texto de Ella Shohat e Robert Stam, presente no capítulo A questão do Realismo no livro Crítica da Imagem Eurocêntrica, é um ponto interessante para articular um fato ocorrido no meu período acadêmico. Shohat e Stam trabalham no texto uma perspectiva de verdades contingentes, ou seja, qualificadas sob certas perspectivas que informam a visão de mundo de certas comunidades. Para tanto, os autores distinguem o realismo como objetivo (assim como o desmascaramento das redes causais de Brecht) e o realismo como um estilo que produz um "efeito de realidade" ilusionista.

No segundo semestre de 2003, eu realizei uma matéria de Direção Televisiva e propus um piloto de um programa chamado Atitude. Era um piloto que se assemelha ao programa Manos e Minas (desde 2008 no ar), realizado atualmente pela TV Cultura de São Paulo e que traz expressões culturais de periferia. Minha ideia de programa percorria este caminho e para tanto contei com o apoio do grafiteiro Fê, da Freguesia do Ó, para realizar o grafiti do cenário e também tive a enorme ajuda da atriz Ana Paula João Demambro, que apresentou Atitude e era atriz da série Turma do Gueto. Eu não tive muito apoio na minha turma de graduação para a execução do programa, apenas de uma colega ainda de Rádio e 
TV que cumpria créditos obrigatórios para a sua graduação tardia. Aqui entre nós, realmente ela topou o projeto porque eu e ela sobramos. $\mathrm{O}$ apoio do grupo da turma que fazia a disciplina veio somente quando os professores desta matéria dividiram as atribuições a serem realizadas pelos grupos. De fato, os assuntos que eu queria abordar não era obrigação para nenhum dos colegas de turma defendê-los, no entanto esse afastamento já dizia muito da relação com um discurso incômodo que de alguma forma eu exercia na universidade talvez até inconscientemente.

Vários grupos na turma se juntaram e realizaram seus programas televisivos, um deles realizou paródia de um programa televisivo chamado I wanna be, exibido em 2003 pela Music Television do Brasil (Grupo Abril e Viacom). O programa consistia em fazer de um fã a figura em semelhança de seu ídolo, para tanto valia-se de modificações nos cabelos, nas roupas, modo de caminhar, dentre outras coisas. A Paródia elaborada no caso deste piloto de programa simulava três fãs que disputavam entre si quem mais se parecia com a cantora Wanessa Camargo, filha do famoso cantor sertanejo Zezé di Camargo. Wanessa Camargo se tornou uma cantora Pop desde aquela época (2003) e ela se destacou também pela sua beleza com grandes cabelos lisos, pelas suas vestimentas as vezes consideradas cafonas e pelos relacionamentos amorosos que frequentavam páginas de revistas sobre Famosos.

No programa paródia, a disputa entre as três concorrentes a "Mais parecida com Wanessa Camargo" seria avaliada por personagens também paródicos. No caso eram a empregada de Wanessa (não a toa, uma atriz morena com sotaque nordestino), um fã (ator loiro) e uma amiga de infância (atriz loira) de Wanessa. 
Desde a concepção do piloto deste programa, a escolhida para ser ganhadora como Wanessa parodiada, consentidamente por todos do grupo, foi uma das minhas colegas de turma que é negra. Ela topou dublar e representar a cantora.

O programa em si não trouxe nenhum elemento de humor a não ser a tentativa de riso através do que esta colega de turma representou na simulação em querer se parecer com Wanessa Camargo. Num misto entre o visível constrangimento e o topar a representação, a tentativa cômica estava naquilo que os outros graduandos da turma achavam graça na memória da situação: uma garota que nada tem a ver com a Wanessa Camargo, tentar sê-la. Para compor a personagem, esta colega negra da minha turma alisou seus cabelos, vestiu-se com vestido rosa curto, listrado e agarrado (bem diferente do que ela usava cotidianamente), calçou grandes botas pretas e dublou uma canção de Wanessa Camargo. Eu não achei graça naquilo que julguei como imaturidade de meus colegas de turma em realizar um piloto de programa que só tinha graça enquanto piada interna fixada pelo jeito de ser tímido da colega de turma que nem era tão próxima a mim. Eu me sentia mal ao vê-la realizar a tal paródia. Na ocasião, veio na minha lembrança humoristas negros como Tião Macalé, Mussum e Buiú que exerciam sua comédia através de seus corpos e caras negras em papéis que representavam ingenuidade, desatenção e pouca inteligência diante daquilo que significava suas realidades. Personagens estanques que preenchiam um lugar natural na comicidade das nossas relações de poder; afinal Tião, Mussum e Buiú não saíam de suas representações talvez até fora de seus personagens. Os colegas da minha turma quiseram construir essa representação através de uma colega negra da turma que estava ali em condição de igualdade com todos. As risadas e os 
comentários dos colegas de turma estavam na performance constrangida da colega negra. Uma mulher negra que quer parecer com Wanessa Camargo e em nada se parece com ela. Achar graça naquilo que representa diversas tentativas de muitas mulheres negras se enxergarem como possíveis enquanto mulher que se vê e se enxerga em beleza.

Você pode argumentar que a escolheram pelo fato talvez desta colega negra ser tímida. Mas havia outras garotas na turma que também exprimiam sua timidez e que eram muito próximas ao grupo que realizou este piloto de programa. Tudo indica que o regozijo cômico estava naquilo que o corpo e o rosto desta colega negra poderia representar a ingenuidade de uma preta que tem sua identidade perdida e afogada numa representação de beleza de alguém (Wanessa Camargo) que também busca se parecer com o belo eurocêntrico (Stam e Shohat). De qualquer forma, todos fizeram seus trabalhos, o desempenho desta colega - no lugar em que ela ocupou - foi aplaudido. Os colegas de turma se satisfizeram de maneira geral, professores atribuíram boas notas, desempenho técnico primoroso com uma abertura feita em programa de efeitos especiais... E tudo circulou na mais harmônica e completa naturalidade; como se o comum e a uma das normas naquela sociabilidade fosse exercer a comicidade necessariamente no que pôde representar aquele rosto e corpo da colega negra.

Uma outra colega negra minha que ainda realiza graduação em Arquitetura e Urbanismo na FAU/USP entrou para a atlética desta faculdade. Nos ensaios da bateria, membros da atlética buscaram a figura de uma rainha da bateria para representar a FAU/USP nos jogos universitários. Houve uma disputa meramente 
simbólica na qual a vencedora mesmo sem ter se inscrito oficialmente era justamente esta minha amiga, graduanda negra em arquitetura. Para o grupo da atlética, ela era a mulata "globeleza"18 da bateria e ninguém senão somente ela poderia representar este papel. O constrangimento dela estava aliado ao fato dela não saber dançar samba, mas isto não importava; pois em nome da atlética; todos, homens e mulheres a queriam e desejavam como mulata da bateria. NÓS TEMOS A VÊNUS HOTENTOTE ${ }^{19}$ ! Conversando com esta amiga, ela me disse que considera o fato bem estranho, mas ao mesmo tempo ela achou sua eleição como rainha da bateria, a Mulata, um fato normal porque há poucos negros e negras na graduação em arquitetura. O que confere a normalidade desta aclamação pública pela figura da mulata? Positividade e negatividade se unem para reiteração de determinados lugares mesmo numa condição de igualdade.

Outra garota negra que ainda faz graduação em Artes Cênicas tem medo de mim. Estranho, não? Outro dia, perguntei como ela se entendia como negra em seu cotidiano. Ela me respondeu que tudo era normal independentemente se ela era azul, verde ou vermelha. Depois, ela começou a me evitar. Fugia de mim quando estava no mesmo espaço. Não sei quais das minhas caras ela evitava, a azul, a

18 Nos anos 90 e início de 2000, as vinhetas dos desfiles carnavais do Rio de Janeiro e de São Paulo eram protagonizadas pela dançarina Valéria Valensa. Como a emissora que veicula estes desfiles é a Rede Globo, Valéria Valensa foi batizada de Mulata Globeleza. Desde então, Mulata Globeleza é um termo que é utilizado com relativa frequência para demonstrar a beleza de mulheres negras.

19 Vênus Hotentote foi o apelido recebido por Saartjie Baartman (1789 - 1815), mulher sulafricana da etnia khoisan. No início do século XIX, Saartjie se apresentava em Londres numa espécie de circo dos horrores sob a promessa de bom retorno financeiro oferecido pelo irmão de seu antigo patrão na África do Sul. Saartjie tinha grandes nádegas e tinha grandes lábios vaginais, essas características eram alguns dos fatores para exotizá-la no Circo dos Horrores. Ao longo de sua vida na Europa, Saartjie foi vendida e escravizada nesse show de horrores, sendo que antes da sua morte, ela se prostituía na França. Quando morreu, Saartjie teve seu corpo retalhado em partes para estudo "Memoires du Museum d'Histoire Naturelle" (1817), publicado por Henri de Blainville. $O$ modelo em gesso do corpo de Saartjie e seus órgãos genitais conservados em formol ficaram expostos no Museu do Homem (Paris) até 1974. Somente em Maio de 2002, o corpo de Saartjie retornou a sua terra natal para sepultamento. 
verde ou a vermelha. Talvez evitasse perder suas amizades universitárias. Penso que foram duramente conquistadas, pois eu nunca a vi ao lado de algum outro rapaz negro ou alguma outra garota negra.

Nesta experiência universitária no mínimo contraditória, lembro de vários impedimentos que tive no ambiente universitário como, em festas da ECA, ser freqüentemente confundido como vendedor de maconha por alunos bêbados, como na Praça do Relógio do campus da USP ser tomado como estuprador que agia na região pela Guarda Universitária, como no Instituto de Psicologia ser barrado na portaria por eu não ter "cara de aluno", como da vez em que a secretária do departamento onde eu estudo naturalmente pedir para que eu pegasse alguns objetos numa outra sala, pois julgava que eu era um funcionário da ECA/USP. Ou então quando bixetes seguravam suas bolsas me confundido com alguma figura que não um aluno. Diversas pessoas do meu bairro me perguntam o quanto pago por mês para estudar na USP. Pago o preço de ser um rosto e um corpo diferente da cara de aluno da USP.

Sem querer o segurança do prédio da psicologia disse algo muito relevante, ele teve a coragem de verbalizar o incomodo no qual muitas pessoas não proferem. Se ele partiu do pressuposto que eu não tenho cara de aluno da USP, quer dizer que socialmente existe um conjunto de significados que pode representar a Cara de um aluno da USP. Não é a pergunta "Quem seria este rosto?" que indica uma provável resposta às práticas cotidianas neste lugar; mas sim a pergunta "O que é este rosto e o que ele significa?" abre para maiores interpretações nas quais é possível se constatar quais relações de poder são construídas, herdadas e revalidadas em que 
se rege o conforto de uma branquitude normativa.

Este rosto branco, ao que parece, significa o normal. Duvida? Em 2007, quando terminei minha graduação, eu trabalhei numa produtora televisiva que realizava o conteúdo de programação da TV Ideal (antigo canal da TV Abril que era focado no universo corporativo). Acima de mim na hierarquia, havia uma jornalista que além de produtora, ela era também redatora/pauteira. Eu produzia dois programas televisivos, um deles, o Confraria Ideal, era o encontro de quatro convidados(as) executivos mediados por uma apresentadora. Estes encontros versavam sobre diversos temas advindos de gostos em comum, hobbies, atividades esportivas dos convidados. Um dia eu propus para esta jornalista pauteira, um programa que reunisse quatro executivos(as) negros(as). Ela achou interessante a ideia, mas não quis racializar a discussão. Para ela, poderia ser feito um programa em que reunisse executivos ou executivas "diferentes" e enumerou: Negros, cadeirantes, gays, gordos. Era a "Confraria da Diferença". Ela dissuadiu da ideia quando o diretor do programa disse que temas como esses não cabem nesta produção porque são muito pesados e trazem histórias de sofrimento. Além disso, segundo este diretor, o programa Confraria Ideal é uma atração alegre e que deseja deixar o espectador bem. Assim, não era pra trazer histórias com negros, deficientes, gays, entre outros; fato que espantaria os telespectadores. Nesta discussão do que é normal e diferente, para a presunção da diferença, existe algo que poderia ser considerado o "normal", ou a norma. O normal é branco, por excelência. A branquitude ali tão tranquilamente proferida respondeu para quem o conforto dos normais é exercido. 
Este é o paradoxo que não conseguimos vencer. De um lado, o poder conservador barra, através de efeitos estatísticos, a sensibilidade do sistema político diante do dilema racial. De outro lado, os grupos afetados - dos quais não se pode falar em minorias, como nos Estados Unidos - estão aquém das relações de poder e do controle da influência política, na esfera racial, são relegadas ao crescimento espontâneo e ao azar.

\section{$(\ldots)$}

É preciso insistir sobre esse paradoxo. Nenhuma democracia será possível se tivermos uma linguagem "aberta" e um comportamento "fechado". O fato de as pesquisas sociais avançarem até as fronteiras do desmascaramento da nossa "constituição íntima", como sociedade nacional e das nossas técnicas sociais estarem na idade da "cultura tradicional" constitui um fato chocante. Numa era em que a avaliação e o uso dos recursos humanos deram um salto revolucionário, nós nos apegamos, obstinadamente, a procedimentos ultrapassados e destrutivos. Como poderá o Brasil entrar na categoria de 100 milhões de habitantes com uma estatura tão pequena, sem mesmo contar com um esforço organizado e o intento de possuir políticas especiais adequadas à solução dos problemas culturais, étnicos e raciais de sua população? (Fernandes, 1973, p. 162)

A experiência que trago é essa dificuldade como negro na relação que se estabelece na universidade. Obviamente não desejo colocar palavras na boca de ninguém, afinal há pessoas negras que não relatam passar por esses problemas na universidade. Por outro lado, eu me pergunto o quanto essas pessoas se subalternam; ou como a colega de Artes cênicas, o quanto foge de outro negro em nome da sociabilidade conquistada. Parece que o paradoxo faz parte de algumas manutenções e quais delas, elitistas, são reiteradas num departamento como o de Cinema, Rádio e TV na ECA/USP? Quem entra no vestibular aqui? Não faço esta pergunta direcionada aos graduandos que entram aqui e tampouco à cor de pele deles. Eu sei que são herdeiros brancos, na maioria e que vieram de escolas caríssimas nas quais se vive o conforto dos negros nos seus lugares. Mas provoco perguntando o quanto partilham inerentemente de toda essa ideologia que trabalha nesta manutenção em que o normal é aquilo significa o branco por excelência e o 
quanto dessa ideologia perpassa nos filmes realizados por aqui reiterando este princípio em bem herdar o conforto e a recorrência do preto e seus significados no seu seguro lugar periférico.

Enxergo a sociabilidade da pessoa negra nesta universidade pública operando num duplo: ao mesmo tempo em que ela realiza uma tensão gigantesca sobre a pessoa negra que está em condição de igualdade em relação aos outros alunos com 'cara de USP', ela também faz com que a identidade negra fique notoriamente mais aflorada e presente. Para aqueles negros com vergonha de serem negros, na USP eles são direcionados a tomar uma atitude: ou compreende a sua presença universitária ou faz como o Aluno de Arquitetura entrevistado pela professora antropóloga Moema de Poli Teixeira, Eu devia ter feito alguma coisa, mas eu não fiz nada. Pelo menos ele sentiu a presença ideológica desse mal-estar; muitos, para manter as aparências, as amizades brancas ou os amores brancos conquistados, preferem se calar para não perder estas coisas preciosas. Há que se frisar que muitas vezes estas opções não são conscientes. Afinal, ficar calado pode ser um crachá de livre trânsito no território elitista e aristocrático de uma universidade pública. Além disso, este silêncio pode funcionar antes que a normalidade das relações na universidade pública possa colocar o negro no seu devido lugar. Calar-se talvez seja melhor do que o nada de um corpo negro vagando só na universidade em busca de conhecimento sem amizades pretas ou brancas.

Em 2005, quando defendi um projeto inicial da série televisiva "Sociedade Anônima" como projeto de Trabalho de Conclusão de Curso a ser produzido, pelo menos como piloto de série, eu tive que apresentá-lo a minha turma e a três 
professores que avaliam quais propostas serão filmadas ou produzidas. Ao defender o protagonista Rodrigo como um rapaz negro que trabalha como motoboy e que batalha para entrar no curso de Arquitetura numa faculdade pública como a USP, uma das professoras desta banca me disse que Rodrigo soava inverossímil, pois o vestibular em Arquitetura e Urbanismo é muito difícil. Para ela, era muito mais factível que Rodrigo, meu personagem, tentasse uma graduação em Letras ou numa faculdade particular. Ela justificou que até para os alunos que estudam muito, um curso de Arquitetura era difícil para se entrar e estudar lá, imagine para um motoboy como Rodrigo?

O que fez minha professora, na minha graduação, intuir que meu personagem estuda menos e/ou pode menos? Talvez meu personagem funcionava como a colega preta que "quis ser" Wanessa Camargo e nunca seria. Naquele processo de defesa, eu também estava novamente num julgo alheio no qual eu teria menos conhecimento que meus outros colegas de graduação. É importante seu esforço, mas há algo que lhe falta... você não sabe falar nosso idioma normativo. Ali senti na pele qual era o jogo na relação estabelecida naquele momento.

Como é arraigado e interessante a invisibilidade e as estereotipias do negro, da negra... Como é real o desejo pela posição subalterna da pessoa negra que, para manter a sociabilidade, ela se torna coadjuvante de sua própria vida... e quando se torna protagonista, vira um processo controlado para se atender fetiches dessa nossa ideologia branca desumanizadora envolta na normalidade de uma branquitude tão avassaladora e tão negada. Exaltamos nossa mestiçagem ao mesmo tempo em que exotizamos o corpo da mulata numa relação de inferioridade. Importante 
destacar que justificativas como esta realizada por uma pessoa que me lecionou aqui na ECA/USP não são racionalmente deliberadas, elas estão no conforto das qualidades nas relações estabelecidas. Nesta universidade em que, até aqui, tenho que me negociar na alma branca do negro; o popular, o negro não são protagonistas no audiovisual que estudo aqui na academia. Na periferia, na margem, na "imargem", o negro é frequentemente objeto de estudo em faculdades como a FFLCH/USP. Talvez por isso, dos negros que estão na USP, muitos deles encontram suas identidades e explicações para fatos ocorridos com eles através destes estudos sobre o negro.

Estudar o negro na universidade é diferente de ser este negro na universidade. Olhar para meu passado e compreender diversas relações estabelecidas não é me vitimizar ou indulgenciar dó alheia, tampouco seria me glorificar ao dizer que venci todos os preconceitos para estar incluído ou ser reconhecido como cineasta. Esta vista pelo meu passado tenta compreender os tons mais sutis de um discurso paradoxal que exerce o enjaulamento do que significa negro ao mesmo tempo em que se exotiza, edulcora-se e se vangloria nossa mestiçagem e a nossa paz da integração do negro na nossa sociedade. Ao galgar possibilidades de igualdade, para o negro e a negra é onde mais se sente e se enxerga os discursos que apartam.

"Tendo o campo de batalha sido delimitado, entrei na luta. Como assim? No momento em que eu esquecia, perdoava e desejava apenas amar, devolviam-me, como uma bofetada em pleno rosto, minha mensagem! O mundo branco, o mundo honesto, rejeitava minha participação... Eu acenava para o mundo e o mundo amputava meu entusiasmo. Exigiam que eu me confinasse, que encolhesse." (Fanon, 2008, p.107) 
Realizando a graduação em Audiovisual eu me questiono se somos cineastas ou se somos também construtores de jaulas para alocar nossos Dadinhos, Zé Pequenos, Laranjinhas no nosso zoológico audiovisual em que a tela nos protegem bem na nossa ideologia. Em minha graduação, não discutimos o legado de Abdias do Nascimento ${ }^{20}$ no teatro e na dramaturgia brasileira. O Teatro Experimental do Negro, que possibilitou elencos protagonistas de filmes como Orfeu Negro e Sinhá Moça (1953, Tom Payne) não é comentado. Centros Populares de Cultura da União Nacional dos Estudantes que tiveram um papel preponderante para cineastas do cinema novo nos anos 60 e que tiveram grande contribuição de atores como Antônio Pitanga, Milton Gonçalves e Zózimo Bulbul... silêncio. Como primeira lição de casa, eu tive que engolir a seco o filme ode a klu-klux-klan O Nascimento de uma Nação (D.W.Griffith, 1913) sem discutir seu viés ideológico. Um abraço negro, um sorriso negro... Não, não, não aqui, por favor. Isto é uma universidade! Se quiser discutir essas coisas de negro, vá para a FFLCH e lá você vai encontrar vários antropólogos que entendem dessas coisas de negro.

Na minha graduação, antes de compreender e tecer os devidos apontamentos e/ou críticas a representação da periferia em obras audiovisuais como Cidade de Deus, Tropa de Elite, Antônia, Cidade dos Homens; percebi que deveria compreender como algumas pessoas trabalharam em relação a periferia no departamento onde estudei cinema, rádio e TV. Assim, em 2007 eu encontrei um trecho de uma tese de doutoramento de Roberto Franco Moreira, cineasta e

20 Nascido em 1914, em na cidade de Franca (SP), Abdias do Nascimento foi teatrólogo, poeta, político e ativista social. Ele foi um dos principais intelectuais brasileiros e pautou sua vida na reflexão da contribuição africana e negra na nossa cultura brasileira. da cultura. Abdias era ativista do Movimento Negro foi um dos fundadores do Teatro Experimental do Negro, que objetivava valorizar a presença do negro no nosso teatro e criar uma nova dramaturgia que levasse em conta o legado negro na nossa cultura e a presença do negro. Abdias morreu em Junho de 2011. 
professor que leciona no departamento de Cinema, Rádio e TV da ECA/USP:

"Ao localizar a ação do roteiro em um bairro periférico de São Paulo e escolher como personagens principais matadores, procurei uma situação limite. Nessas regiões a presença do Estado é problemática, senão nula. A violência está completamente incorporada ao cotidiano, seja dentro da família, como atestam os inúmeros casos de abuso sexual e incesto, seja nos bares, ponto privilegiado de encontro e chacinas. O baixo valor atribuído à vida indica esta sociabilidade primária, ditada por impulsos imediatos e carências inadiáveis. Aqui, o desejo não se sublima em afeto, mas se degrada em gula. - São as consequências intersubjetivas de segregação social: viver à margem embrutece e desumaniza.

A violência no Brasil tornou-se norma social. Ao contrário da visão girardiana onde a alta entropia do sistema acaba por impor uma ordem, aqui criou-se uma ordem que convive sem problemas com um alto grau de violência. O matador goza de prestígio e reconhecimento em seu bairro." (Moreira, 2001, p. 115 - 116).

A tese de doutoramento de Roberto foca questões intrínsecas sobre o sentido da violência. Esta tese também desenvolveu um roteiro cinematográfico que resultou no longa metragem Contra Todos (2004, Roberto Moreira). Apesar deste filme trazer o espaço periférico e ser, de certa forma, contemporâneo ao Cidade de Deus e Quase Dois Irmãos (2005, Lúcia Murat), este filme não trouxe protagonistas negros na sua trama, mas sim dois personagens secundários negros. Contra Todos traz a história de Júlio, um matador de aluguel que tem diversos problemas na relação com sua filha jovem e sua nova esposa. Interessante a interligação imediata entre retratar o cerne da violência e a utilização de um espaço periférico para isto. Mais interessante é se ater aos dois personagens negros secundários: um é assassinado sendo que o diálogo em que o espectador toma ciência desta morte é feito através de um comentário jocoso da filha de Júlio sobre o órgão sexual do negro assassinado. O outro personagem que é matador de aluguel (foi interpretado pelo ator Aílton Graça) é a personagem amoral que articula e amarra as consequências e 
decorrências trágicas durante o filme. Há ainda uma cena dos matadores em ação, eles abatem negros num barraco de favela, tudo isto é realizado de uma forma cotidiana e porque não, higiênica. O filme Contra Todos não discute questões raciais, mas ao focar na compreensão dos sentidos gerais de violência, acaba utilizando muito diversos lugares comuns na representação da periferia e do negro. Fica uma sensação de fetiche ao tornar visível o assassinato daquelas pessoas negras na sequencia de ação descrita. Ali, tal qual como ocorreu com a professora ao descrever o personagem motoboy como não tendo capacidade de estudar numa faculdade de arquitetura, Contra Todos bebe também da branquitude para discutir questões sobre violência. Está arraigado, herdado e nato esta maneira de encarar as coisas. Num filme posterior de Roberto Moreira, Quanto Dura o Amor (2009), existem três personagens negros secundários: um porteiro (o ator Aílton Graça novamente), um segurança bruto de uma casa de prostituição (feito pelo ator Thogun) e uma prostituta que se aproveita de um rapaz escritor apaixonado (interpretada pela atriz e cantora Leilah Moreno, que participou do seriado e filme Antônia).

No audiovisual, negociamos o que há de fato na periferia. Na minha vivência, percebo que ela não é só um espaço de falta, mas também um espaço socialmente criado para se faltar. E a falta é gerada neste lugar, não da relação que a cria. Assim se exerce melhor a hierarquia e a diferença. Por outro lado, para mim, periferia é também espaço para encontros culturais como o Sarau Cooperifa, o Sarau do Binho, Elo da Corrente, Cinescadão. Neste sentido, periferia se torna identidade e neste lugar é possível exercer tais liberdades que ainda não são possíveis num ambiente acadêmico como da USP. A periferia é também garra para superar esse lugar da 
carência, para criar alternativas, inventar modos de fazer e de viver.

Há que se dizer, talvez até para alguns professores do departamento de Cinema, Rádio e TV, que a periferia também forma, em condição de igualdade, uma pessoa capaz de estudar numa faculdade pública. No meu caso, eu sou uma pessoa negra que mora na periferia e que cursou Cinema, Rádio e TV no mesmo lugar que muitos oriundos de histórias elitistas e aristocratas. Para tanto, a seguir trago um texto que escrevi para o Sarau da Cooperifa em Dezembro de 2010:

\section{Censura sobre tia Nastácia}

No livro "As Caçadas de Pedrinho", Monteiro Lobato escreveu: Tia Nastácia, esquecida dos seus numerosos reumatismos, trepou, que nem uma macaca de carvão, pelo mastro de S. Pedro acima, com tal agilidade que parecia nunca ter feito outra coisa na vida senão trepar em mastros.

...É, Monteiro Lobato, o senhor está envolvido em nova polêmica!

Não é petróleo, não são os vermes do Jeca, nem Paranoia ou Mistificação.

Mas tia Nastácia subiu numa árvore...

Não, Monteiro, não quero lhe acusar ou apontar o dedo na sua cara. Apenas entendo a aristocracia de onde nasceu e viveu. Uma aristocracia que não tinha um projeto, mas sim um ideal de corpo, um ideal de rosto... como se isto conferisse algum ideal de civilidade.

Em sua época, estava claro o que era um projeto de nação e quem participaria dele.

Talvez hoje ainda seja...

Monteiro, atualmente, muitos dizem que algumas pessoas querem the censurar... Ou censurar Pedrinho em suas Caçadas como herdeiro dos desbravadores desta terra.

Mas, Monteiro... penso que realmente quem sempre foi censurada foi a tia Nastácia. 
Tia Nastácia, ao fugir das onças, podia subir na árvore de diversas maneiras e formas.

Tia Nastácia poderia ter reumatismos que a vida nos dá, mas não somente aqueles vindos por servir a vida toda a uma família que é proprietária da Casa Grande, Monteiro.

No entanto, a aristocracia em que você nasceu e o senhor, como bom herdeiro dela, parece enxergar somente que Tia Nastácia poderia nunca ter feito outra coisa na vida senão trepar em mastros... a forma única e recorrente, por sinal.

Sabe, Monteiro... o que me assusta nesta história não é tia Nastácia subir numa árvore, mas sim o silêncio de uma censura atual, de uma história única, com a qual a bisneta da Tia Nastácia não tenha ainda o direito de contar.

(Renato Candido de Lima - Dezembro/2010 - Sarau da Cooperifa)

Em 2006, na minha graduação, já havia cumprido a maioria das matérias obrigatórias e optativas livres do departamento onde eu estudei. Nesta época, eu realizava matérias fora da ECA/USP e meus estudos permearam psicologia, antropologia, sociologia. Eu me debruçava naquelas em que havia discussões a respeito da formação do pensamento brasileiro e de relações raciais em nossa sociedade. Neste ano, através de uma aula de pós-graduação lecionada pela professora Esther Hamburger, houve uma tentativa na construção de uma ponte entre coletivos audiovisuais periféricos e a universidade. Este encontro foi produzido pela mesma professora e pelos graduandos na época Guilherme Cerqueira César e Ricardo Mollan Saito, dois alunos com sensibilidade para questões de representação do negro e da periferia dentro do departamento de Cinema, Rádio e TV. Este encontro fez parte de um projeto capitaneado pela Prof. ${ }^{a}$. Dr ${ }^{a}$. Esther Império Hamburger, financiado pelo CNPq e depois também pela FAPESP; dentre suas atividades, havia a realização de encontros no auditório "Paulo Emílio Sales Gomes" da ECA/USP entre realizadores periféricos, professores do departamento e alunos 
de pós-graduação da época. Numa determinada altura deste encontro, tive receio de sentir que aqueles protagonistas audiovisuais periféricos estivessem lá como objeto de estudo para alunos pós-graduandos da USP. Afinal, não havia ninguém da quebrada naquela Pós-graduação. Lá, os realizadores(as) da periferia vieram divulgar e discutir seus trabalhos na universidade. O projeto financiava despesas de transporte e alimentação. Esses encontros realizaram, ainda que de maneira efêmera, o sonho desses realizadores por conhecer a universidade e serem possíveis nela de alguma forma. E de outra parte propiciaram o encontro entre alunos de graduação e pós-graduação e professores da universidade com coletivos e realizadores da periferia.

Obviamente que estava lá o estudo das partes da Vênus Hotentote da Periferia que ainda parece suscitar paixões exóticas pelo outro. Mas ali também estava o diálogo e ele foi um ato importante para ocupar a universidade através destas(es) protagonistas. Eu, que de alguma forma talvez lutava para "meu lugar ao sol audiovisual" tal qual como concebia naquilo que aprendi na universidade, foi justamente nela, neste espaço que está cerceado a periferia, que encontrei diversos parceiros e parceiras audiovisuais da quebrada para trocar experiências, vivências e ideias. Nós não ocupamos a universidade, mas nos utilizamos dela para aproximar diversos coletivos audiovisuais periféricos, e isso foi muito importante politicamente.

Através de Guilherme e Saito, eu conheci o CineBecos (Jardim São Luís) e o Fabicine (Atual Cinescadão, que atua na Vila Nova Cachoeirinha onde moro). Interessante refletir novamente nesta chave dupla da Universidade: Ao mesmo tempo em que marca profundamente as faces de uma branquitude normativa, ela 
também se abre para aquilo em que podemos realizar enquanto universitários. Afinal eu negro também faço parte dela e outros pretos e pretas fizeram e fazem também. Nela não há somente experiências do não lugar do negro enquanto universitário. Entre os poucos negros na universidade, há também uma espécie de "Correio Nagô", troca de ideias cotidianas e de um reconhecimento do negro para o outro negro na universidade. Os espaços de ocupação e de exercício de conhecimento em identidade negra numa universidade como a USP existem assim como uma cidade de São Paulo tem seus espaços periféricos protagonizados geralmente por rostos que necessariamente não representam comumente a identidade de São Paulo. Duvida? Não é São Paulo que ostenta o encontro de povos e a convivência de Italianos, Espanhóis, Portugueses, Alemães, Russos (Vila Zelina), Libaneses, Judeus, Japoneses? Qual é o rosto de São Paulo? Viva a mistura!.. Mistura de quem? Acredito que esses povos não tiveram que se negar e negar suas interpretações de mundo quando chegaram aqui. Mas de maneira incrível, eu lembro muito bem na minha infância as chamadas do SBT que eram veiculadas em virtude do aniversário de nossa cidade. Nelas não havia nordestinos, negros e outros migrantes que compunham a tal "cara de São Paulo".

Poderíamos afirmar que a cidade de São Paulo não segrega a periferia por conta das diversas manifestações culturais que são protagonizadas pelos seus moradores, mas isto soaria no mínimo falso. Mas há aqueles na Universidade que dizem que uma universidade pública como a USP não segrega o negro por causa da existência de discussões sobre o negro nela ou afirmar que pelo menos há negros nela. Isto para mim já é algo muito significativo do nosso paradoxo racial. A tensão e o conflito não se arrefecem. Valores positivos ou negativos sobre o negro não 
derrubam o muro.

“...não há nada que o pós-modernismo global mais adore do que um certo tipo de diferença: um toque de etnicidade, um "sabor" do exótico e, como dizemos em inglês, a bit of the other (expressão que no Reino Unido possui não só uma conotação étnica, como também sexual). Em seu ensaio "Modernismo, pós-modernismo e o problema do visual na cultura afro-americana", Michele Wallace acertou ao indagar se esse reaparecimento de uma proliferação da diferença, de um certo tipo de ascensão do pós-moderno global, não seria uma repetição daquele jogo de "esconde-esconde" - que o modernismo jogou com o primitivismo no passado - e ao indagar se esse jogo não estaria sendo novamente realizado as custas do vasto silenciamento acerca da fascinação ocidental pelos corpos de homens e mulheres negros e de outras etnias. Devemos indagar sobre esse silêncio contínuo no terreno movediço do pós-modernismo e questionar se as formas de autorização do olhar a que esta proliferação da diferença convida e permite, ao mesmo tempo em que rejeita, não seriam, realmente, junto com a Benetton e a miscelânea de modelos masculinos da revista The Face, um tipo de diferença que não faz diferença alguma. (Hall, 2003, p. 338).

Atualmente a periferia está em visibilidade muito graças a sua própria efervescência. Sarais periféricos de poesias as vezes aparecem na televisão. Para mim que estou tanto neste contexto cultural periférico e na universidade fica a pergunta: Em qual contexto é possível exercer protagonismos negros numa universidade como a USP? Exercer para quem? Para outros jovens filhos de um sentimento elitista que me tratarão como negro exótico (poxa, você é inteligente, sabe falar francês!) ou como um guia turístico da periferia, tratando-a como espetáculo daqueles que se realizava no Necrotério de Paris no final do Século XIX. (Que pena tenho destas pessoas, tão pretas, moram neste lugar, mas estão felizes na falta de dentes que são... Quem sabe poderemos fazer uma ONG para que esses coitados possam batucar numa lata para exercerem sua cidadania no lugar onde estão. Para ficar no lugar onde estão!) Como trazer o que sou e do que articulo como conhecimento sem torná-lo objeto do exótico ou de elixir daquilo que 
representa a classe média, média alta, alta em voltar ao "natural" e "selvagem" da periferia ou me sentir como num comercial da Benetton, como aponta Stuart Hall?

Ser negro na universidade é diferente de ter espaços periféricos da mesma universidade para se falar sobre o negro. Sim, a Universidade Pública tem suas periferias de recursos econômicos. Acontece isso na Faculdade de Filosofia, Letras e Ciências Humanas. No centro dos recursos financeiros da universidade estão faculdades como Escola Politécnica, Faculdade de Economia e Administração, Faculdade de Direito que dificilmente discutem ou problematizam o sujeito negro na nossa atualidade. Provável que seus graduandos brancos, pardos ou pretos (pelo menos um preto deve haver lá!) exerçam o normativo do significado branco sem que tenham necessariamente a consciência disto muitas vezes. É, Carolina Maria de Jesus, parece que os pretos habitam não só a periferia das grandes cidades, mas também aquilo que se entende como espaços periféricos da Universidade Pública.

Como não tenho respostas prontas para estas questões, eu ofereço pistas e caminhos elaborados dramaturgicamente na forma audiovisual. Realizá-las é, primeiramente, colocar-me num sentido negro protagonista, algo que é conquistado a duras penas quando se é negro que discute nossa branquitude. A ideia aqui não é validar a dramaturgia proposta através de algo semelhante ao que aconteceu com o sambista Cartola quando lavava carros em Ipanema e sendo redescoberto por Stanislaw Ponte Preta ${ }^{21}$; ou mesmo com aquilo que ocorreu com a escritora Carolina

21 Stanislaw Ponte Preta era o nome artístico do jornalista Sérgio Porto. A irreverência era sua marca através de programas radiofônicos, televisivos e seus livros. Em 1956, Sérgio Porto re-encontrou o músico Angenor de Oliveira (Cartola), que se destacou através de vários sambas e também pela sua presença na Escola de Samba Mangueira. Na ocasião, Cartola trabalhava lavando automóveis no bairro de Ipanema (bairro classe média alta do Rio de Janeiro). Através do re-encontro, Cartola voltou a cantar e Sérgio Porto o levou para se 
Maria de Jesus que só foi reconhecida quando teve seu diário compilado em forma de livro pelo jornalista Audálio Santos ${ }^{22}$. Estamos numa época que agradecemos a boa vontade daqueles que desejam nos tutelar, mas sabemos da força que nos mantêm em pé e daquilo que sabemos fazer e protagonizar em arte e em comunicação social. Nas dramaturgias audiovisuais que proponho, o interesse está em problematizar justamente as relações e negociações que o negro e a negra realizam em relação a branquitude vigente. Para isto, a série "Menina Mulher da Pele Preta" oferece perspectivas de protagonismos femininos em histórias diversas que pretendem ir além de processos de vitimização ou de ressentimento como se fosse "apontar a cara do culpado". Esta série retrata confortos e negociações que a mulher negra estabelece para se manter protagonista de sua vida.

Assim, esta dissertação também tem seu caráter político (não partidário) no que se refere a ser um texto que pretende contribuir para que outras e outros jovens vindos de um processo enjaulador simbólico da periferia possam ocupar e se apropriar cada vez mais da universidade pública como a USP, por exemplo. Não como espaço de gozo aristocrático, mas sim como troca de conhecimentos. Trago dramaturgias nas quais exerço um rompimento com o lugar comum que se forma em relação a filmes de periferia e obras audiovisuais que tenham o negro e a negra como protagonistas.

Assim como o poema do poeta Luan Luando, que encontro sempre na Cooperifa (Sarau de Poesias da Periferia pra Periferia) e no Sarau da Vila Fundão, 
diz; eu também me denigro. Mas denegrir meu conhecimento é torná-lo sincero comigo mesmo e com a jornada daqueles pretos e pretas periféricos que virão estudar aqui na USP. Eu, protagonista do que sou neste espaço universitário, tomo posse deste lugar com minha cor, com este ponto-de-vista, mesmo que os "Borbagatos" e "Raposo Tavares" universitários e audiovisuais me confundam com traficantes, bandidos, estupradores e outros personagem que não tenham a cara de aluno da USP. Ou que então me confundam com uma pessoa incapaz de escrever um roteiro ou dirigir uma obra audiovisual. Assim, eu desejo que venham outras pretas, pretos, periféricos(as) que ocupem/pluralizem de fato ou deem um outro sentido ao espaço onde está a CASA GRANDE UNIVERSITÁRIA.

\author{
Eu quero me DENEGRIR \\ Regredir aos meus ancestrais \\ Me NEGRIR \\ Eu quero me DENEGAR \\ Que me dê, NEGA \\ HOOOOO NEGA!!!!
}

(Luan Luando - Sarau do Binho - www.tutuliterario.blogspot.com)

Meu lugar no audiovisual não é 'cortar a cana' e 'fazer o melaço' para as pessoas que desfrutam desta ideologia embranquecedora se lambuzem com o caramelo e a doçura dos lugares fixos de nossa confortável convivência. Com o negro e a negra, em seu rostos periférico-cinematográficos, sejam atualizados em novas maquiagens, novas cosméticas e mesmos lugares, resultando numa nova manutenção.

Para aqueles que gozam de certos elitismos, de novos sentidos aristocráticos, envio um recado: Eu estou aqui! Em igualdade! Questionando a ideologia em se 
sentir mal com minha presença! Se o remédio é me esconder ou me enjaular, terá que interromper a posologia do seu tratamento!

Que os tapas na cara que tomei ao estar nos lugares onde meu rosto e meu corpo não eram válidos (apesar do meu conhecimento), que discutir minha origem e ao me propor protagonista deste ponto de vista possam se transformar em resposta frutífera, mesmo que ainda seja árido o terreno para a pessoa negra vinda da periferia aqui nesta universidade pública.

\subsection{Interlocução entre Periferia e Universidade}

$\mathrm{Na}$ demolição, muitas vezes o entulho pode significar que ele não representa mais serventia. No entanto, atualmente quase todo entulho tem possibilidade de ser reciclado. Aqui, de maneira evidentemente metafórica, a tentativa é realizar o reaproveitamento dos restos demolidos dos significados desta Casa Grande Audiovisual e Universitária. Este processo de reciclar deve ser muito criterioso e necessita utilizar maquinários que moem pedras e partes grandes de concreto. Nos restos haverão críticas, mas estes ajudarão a pavimentar um caminho diferente.

Ao discorrer anteriormente sobre experiências do negro numa universidade pública como a USP, tentei focar nas profundezas do "E"; ou seja, ser negro "E" universitário "E" morador da periferia. Este "E", ao meu ver, evoca uma relação que tenta se libertar ou demolir as amarras dos lugares estabelecidos pelo "OU". Ou Universidade, Ou Periferia, Ou Negro. Cada um habitando seu lugar específico e 
confortável dentro das nossas bases sociais herdadas de novas leituras elitistas e aristocráticas. Nesta relação do "E" e do "OU", Stuart Hall traz a seguinte ideia:

O que esse movimento burla é a essencialização da diferença dentro das duas oposições mútuas ou/ou. O que ele faz é deslocar-nos para um novo tipo de posição cultural, uma lógica diferente da diferença, para resumir o que Paul Gilroy tão vividamente pautou na agenda política e cultural da política negra do Reino Unido: os negros da diáspora britânica devem, neste momento histórico, recusar o binário negro ou britânico. Eles devem recusar porque o "ou" permanece o local de 'contestação constante', quando o propósito da luta deve ser, ao contrario, substituir o "ou" pela potencialidade e pela possibilidade de um "e", o que significa a lógica do acoplamento, em lugar da lógica da oposição binária. Você pode ser negro e britânico, negra e britânica não somente porque esta é uma posição necessária nos anos 90 , mas porque mesmo esses dois termos, unidos agora pela conjunção "e", contrariamente a oposição de um ao outro, não esgotam todas as nossas identidades. Somente algumas delas estão, as vezes, envolvidas nessa luta especifica. (Hall, 2003, p. 344-345)

Antes de chegar às propostas dramatúrgicas deste processo em mestrado, é importante detalhar, analisar, tecer críticas e apontamentos sobre as interlocuções vindas do ambiente acadêmico para a periferia. Elas foram muito importantes na percepção da relação entre universidade, periferia e negro; consequentemente foram e são também importantes no processo que gera as dramaturgias deste mestrado. Neste sentido, desde 2005 eu procurei de alguma forma, em meus estudos, tentar elaborar trabalhos, projetos e dramaturgias que pudessem tecer relações ou mesmo envolver pessoas destes três lugares: Periferia, Universidade Pública e Negritude. Na universidade, eu não estava sozinho nessas tentativas. Um dos exemplos disso, como já havia descrito brevemente no capítulo anterior, foi a elaboração em 2006 de algumas pontes entre a coletivos periféricos audiovisuais e o departamento de Cinema, Rádio e Televisão da ECA/USP. O ponto de partida foi a mencionada aula de pós-graduação da professora Esther Hamburger (oriunda de 
projeto financiado pelo $\mathrm{CNPq}$ ) no qual houve a participação de diversos coletivos audiovisuais periféricos; este encontro ajudou a fomentar um projeto de pesquisa da então Professora Doutora Esther Hamburger (anterior a sua livre docência), chamado "Rede de Telas".

Vou me detalhar neste projeto, pois na minha época de graduação e formatura lembro dele ser o único a elaborar estas possíveis pontes de diálogo periferia-universidade a respeito da compreensão de quais imagens são realizadas e consumidas acerca da periferia. Além disso, eu participei deste projeto desde o início e, para tanto, posso tecer um panorama crítico deste projeto como um todo. O ponto de partida ou a hipótese dele dialoga com o texto "Negociando as questões do Espectador" de Ella Shohat e Robert Stam no livro "Crítica da Imagem Eurocêntrica".

Os meios de comunicação têm um papel na formação da identidade na era pós-moderna. Ao entrar em contato com indivíduos nunca vistos, os consumidores dos meios de comunicação eletrônicos podem ser afetados por tradições com as quais não possuíam qualquer ligação anterior. Desse modo, tais meios podem mostrar outras culturas como normais ou exóticas, e podem até mesmo forjar comunidades e identidades alternativas. Embora o cinema possa contribuir para a composição de um imaginário imperialista, como vimos antes, não há nada de inerente no celulóide ou no equipamento que o torne necessariamente regressivo. Os fortes "efeitos de subjetividade" produzidos pela narrativa cinematográfica não são automáticos ou irresistíveis, nem podem ser separados pelo desejo, experiência e conhecimento de espectadores situados historicamente, constituídos fora do texto por estruturas de poder como nação, raça, classe, gênero e sexualidade. (Shohat e Stam, 2006, p. 453)

Ou seja, a ideia foi compreender a complexidade da recepção das imagens sobre a periferia para um público que está na periferia. O "Rede de Telas" foi levado a conhecimento de todos os presentes naquela reunião da aula de pós-graduação na ECA/USP e, tempo depois, ele foi discutido na antiga sede da Organização Não 
Governamental "Papel Jornal" no bairro do Jardim Ângela, Zona Sul de São Paulo. O Projeto consistia na exibição de filmes brasileiros que retratam a periferia, tanto do lado das grandes produções quanto das produções consideradas periféricas, em cineclubes organizados pelos coletivos audiovisuais de periferia presentes na reunião. Como resposta ou resultado, os coletivos realizariam em parceria com a universidade (se fosse conseguido captar recursos extras) um documentário e um compêndio de textos para livro que teria análise das exibições e reflexões sobre a imagem da periferia. Para o livro, tinha-se a perspectiva de circulá-lo no ensino público estadual que seria um importante instrumento político para pressionar a Secretaria de Educação do Estado de São Paulo a realizar, pelo menos para o ensino médio, alguma matéria referente a ensino audiovisual com interesse de formar espírito crítico em relação as imagens consumidas e apreendidas de modo geral. Este projeto contou com financiamento do Fundo de Amparo a Pesquisa do Estado de São Paulo - FAPESP para a realização de projeções e debates. A priori, minha função no projeto foi remunerada e consistia inicialmente em gravar vídeo dos encontros e reuni-los para uma posterior edição de todo o material gravado dos encontros.

Dentro da proposta do projeto, o diálogo entre representantes da universidade de São Paulo (através do Departamento de Cinema, Rádio e TV) e alguns coletivos culturais audiovisuais periféricos se mostrou de início bastante tenso e difícil entre os presentes. O que universidade representa para periferia? O que periferia representa para universidade? Nestas duas questões, qual o legado histórico dessa tensa relação? 
O encontro ali detinha questões políticas muito fortes, afinal estavam representantes de uma universidade que dificilmente contempla periféricos em seu cotidiano e representantes culturais de diversas quebradas que reivindicam muitas vezes espaços protagonistas na universidade. Alguns dos(as) representantes de coletivos, desde a reunião, retiraram-se da discussão, pois entenderam que mais uma vez haveria algum nível de exploração de pessoas e imagens da periferia e que a questão central em ocupar a universidade não estava colocada. Este foi um dos argumentos do Grupo NCA (Núcleo de Comunicação Alternativa), da zona sul da cidade de São Paulo, por exemplo. Duas pessoas ligadas a audiovisual no Bairro da Cidade Tiradentes como o cineasta Tio Pac e o fotógrafo cinematográfico/exibidor Cirilo, além do coletivo CineBecos, da Zona Sul de São Paulo permaneceram parceiras deste projeto. O CineBecos foi iniciado através de três jovens oriundos das atividades realizadas pela ONG Papel Jornal que resultavam no jornal Becos e Vielas Z/S. Os jovens eram três graduandos da PUC moradores do Jardim São Luís e do Capão Redondo, zona Sul de São Paulo. Eles eram Rogério Pixote, bacharel em multimeios; Juliana Santos, bacharel em Letras e Anderson Silva, bacharel em economia. Pouco mais tarde, o CineBecos teve o ingresso de Luciana Dias, cientista social pela FFLCH/USP e logo depois o meu ingresso no coletivo. Todos estes integrantes têm em comum o fato de morarem em periferia e (novamente o "E") serem universitários.

Durante o ano de 2007, houveram exibições mensais no CineBecos (Jardim São Luís) e na Cidade Tiradentes através de Tio Pac e Cirilo, mas elas tinham dificuldades de divulgação e consequentemente não realizaram um número considerável de público. Num dado momento, o público das sessões começaram a 
rarear ainda mais, principalmente na Cidade Tiradentes que tinha exibições aos sábados num horário noturno que rivalizava com outros eventos da região como cultos evangélicos, bailes, festas, entre outros. Teve exibições na Cidade Tiradentes em que não houve público, como aconteceu por exemplo quando se exibiu o filme Antônia no Centro Esportivo Juscelino Kubitscheck, no bairro de Inácio Monteiro, onde o frio de inverno e a má divulgação foram determinantes para a ausência. Além disso, a infra-estrutura para as exibições nunca fora ideal nestes espaços. No CineBecos, por exemplo, contávamos com o apoio da Casa de Cultura do M'Boi Mirim e os filmes eram exibidos ao ar livre, pois a tela de cinema e os tripés dela fornecidos pelo projeto não cabiam dentro da sala desta casa de cultura; algumas vezes as exibições foram em domingos de inverno com ameaça de garoa. Quando as exibições foram realizadas no espaço interno desta casa de cultura, o lugar não favorecia a execução do som dos filmes exibidos, além das cadeiras de plástico que não ofereciam conforto (algumas delas estavam quebradas, inclusive).

$\mathrm{Na}$ Cidade Tiradentes, as exibições estavam de forma itinerante e não se encontravam muitas vezes lugares adequados para som e projeção. Ficava nítido o descompasso na produção local de Tio Pac, Cirilo e Iracema (universitária e moradora do bairro que produziu algumas das projeções) para viabilizar lugares de exibição e isso se refletia, por exemplo, através da relação estabelecida com Guilherme Cerqueira César, graduando em audiovisual que estava envolvido neste projeto. Para Tio Pac e Cirilo, Guilherme (apesar de estar no cotidiano do bairro da Cidade Tiradentes) era o representante da universidade e para tanto seria através dele que haveria a circulação da remuneração do trabalho realizado para o projeto. 
Também, naquele momento, pensei que é difícil convidar um público que deseja conforto num final de semana e não oferecê-lo, de fato. E outra, os problemas de representação da periferia não necessariamente são prioridade para quem mora nela. Cativar público para esta discussão aos sábados e domingos no período noturno foi e ainda é bastante desafiador. Naquela época, minha opinião se sustentava na utilização de uma infra-estrutura presente em alguma escola CEU (Centro Educacional Unificado), mas isso esbarrava em articulações políticas destes coletivos com os gestores culturais destas escolas da região.

Ao final do ano de 2007, o cotidiano do projeto trazia a sensação de que menos pessoas iam para as exibições. Diante dos fatos, O CineBecos sumiu (não se retirou oficialmente) do projeto "Rede de Telas" no final deste ano; Cirilo, Iracema e Tio Pac se retiraram logo depois. No CineBecos, seus integrantes optaram por focar seus estudos na universidade (estavam em trabalhos finais de graduação) e também já havia um desgaste na relação do coletivo com a universidade que se refletia, por exemplo, na filmografia a ser exibida. No caso de Tio Pac e Cirilo, seus integrantes escolheram se dedicar a outras atividades culturais que pudesse caminhar sozinhos em relação ao projeto. Cirilo é projecionista e batalha para abrir um cinema na Cidade Tiradentes, Tio Pac é cineasta e arte-educador e preferiu se dedicar ao que ele já realiza, Iracema retornou a sua terra natal para cuidar de alguns problemas de saúde ocorridos com ela. Mas de modo geral, para estes dois coletivos, o baixo comparecimento de público muitas vezes levava as discussões a ficarem restritas a questões que pré existiam à projeção dos filmes, motivo pelo qual o projeto "Rede de Telas" migrou seu foco para o público discente na modalidade de ensino "Educação de Jovens e Adultos - EJA" nas escolas CEU das mesmas regiões 
focadas. Infelizmente os parceiros do Cine Becos não acompanharam a migração do projeto para o programa EJA do bairro do Jardim São Luís, o que empobreceu os encontros naquele bairro. Já na Cidade Tiradentes, os parceiros continuaram a participar do projeto, que conseguiu em alguns momentos atrair, alem dos alunos do EJA, ativistas ligados a outros coletivos.

Apesar de eu ter participado e me dedicado a muitas projeções no Rede de Telas" nos dois anos de duração do projeto, há também que se distanciar para compreender e elaborar algumas críticas não num sentido de fustigar somente pela crítica em si; mas sim entender como alguns lugares se mantiveram mesmo quando o desejo do projeto caminhava numa hipótese de desconstruir estereótipos dos filmes que retratam periferia e também sobre a recepção de obras audiovisuais por parte dos espectadores moradores de periferia. Desta forma, a crítica não é direcionada a pessoas, mas às relações estabelecidas e como estas dialogam com o "curto circuito" entre aqueles que sempre representaram a universidade na branquitude e aqueles que sempre representaram a periferia na negritude.

Por outro lado, como resposta a isto, a sensação recorrente era que tanto Cirilo e Tio Pac estavam no projeto pela remuneração que era destinada a eles e só. No diálogo muitas vezes difícil entre a universidade e estes protagonistas culturais de espaços periféricos, ficou ainda mais evidente a sensação de que existe algo muito mais profundo que distancia esta relação. Digo isto pelos dois lados. Por exemplo, os equipamentos como câmera, luz, gravadores de áudio e microfones estão destinados aos graduandos do departamento e suas produções. Quem são os graduandos de modo geral? São pessoas da periferia como Tio Pac, Oubi, Rogério 
Pixote que vencem a maratona do vestibular da Fuvest para entrar no concorridíssimo curso de Bacharelado em Audiovisual? Desculpe, não são.

Num dado momento, Tio Pac e Cirilo, talvez num cansaço que se materializava, por exemplo, no deslocamento da Cidade Tiradentes até a Cidade Universitária $(45 \mathrm{~km})$, acabaram por se relacionar ao projeto como funcionários do mesmo. Para eles, o "lucro" do projeto vinha efetivamente das remunerações e pouco se utilizou do espaço universitário para ser uma provocação de suas presenças no ambiente da universidade, por exemplo... o que importava era a grana que a universidade poderia oferecer. Assim, o lugar deles estavam dados, não por imposição do projeto ou de sua coordenação, mas pela relação estabelecida. Nela, minha atual orientadora podia parecer muitas vezes a patroa do projeto e a secretária do Departamento de Cinema, Rádio e TV a gerente; quem seriam os funcionários?.. Bem, o Tio Pac é preto... Tio Pac não foi vítima, penso que ele encontrou um cotidiano confortável nos lugares distantes, a materialização disto foi a espécie de salário mensal que o projeto destinava. Perceba que as críticas não são direcionadas ao Tio Pac, Cirilo, Esther e a Secretária do departamento; meu exercício aqui é interpretar quais lugares fixos se mantiveram na execução do projeto apesar do mesmo projeto poder questionar e re-interpretar os mesmos lugares fixos colocados.

Neste sentido, essa sociabilidade parece muito introjetada de maneira que encarar estas coisas está dada. O fato é que o cansaço do diálogo "caiu" para uma "vala comum" do nosso cotidiano em que senhor de engenho tenta conversar com seus escravos e vice-versa, mas senhor de engenho continua dono da terra, das 
ferramentas de trabalho e do dinheiro; o colonizado continua a contar com de sua mão de obra para render o dinheiro do mês; no caso do projeto, a analogia se dá pela parte destinada do dinheiro da FAPESP.

O encontro entre universidade e periferia é muito tenso e pensando numa hipótese de um cotidiano universitário em que pessoas como Tio Pac, Rogério Pixote, Daniel Fagundes do NCA compartilhassem o mesmo espaço do departamento de Cinema, Rádio e TV da ECA/USP com os alunos de graduação; quais seriam as perturbações sentidas se protagonistas periféricos manipulassem câmeras de alta definição (HDV, Panasonic HPX-500) ou Super 16 (ARRI XTR $16 \mathrm{~mm})$ de película? Professores do departamento tensionariam? Funcionários e graduandos também? Ocorreriam julgamentos do tipo "Eles não estão preparados para usar estes instrumentos"? Um departamento como de Cinema, Rádio e TV tem seu objetivo em atender aquilo que é sua função universitária e acadêmica que é de formar os graduandos de bacharelado em Audiovisual. $O$ fato de ser um curso muito concorrido, faz com que poucas pessoas vindas da periferia circulem neste espaço. Assim, num futuro próximo quais serão as tensões quando pessoas da periferia vencerem o "gargalo" da Fuvest e interagirem neste espaço universitário? Há que se ter consciência de tensões que são históricas nesta relação daquilo que sempre representou o rosto da periferia e da academia.

Nossa convivência é como uma máquina centrífuga que separa elementos de um mesmo líquido. No momento em que se movimenta, enxergamos que todos estão misturados; mas ao desligar esta mesma máquina, nós nos utilizamos da decantação desta mistura para escolher ideologicamente nosso branco na 
branquitude e o negro na parte debaixo deste líquido. Dizer que há movimento, assim como dizer que pelo menos há negros numa USP, que a mestiçagem arrefece nossas tensões raciais ou mesmo que as discriminações raciais no nosso país são pontuais, são como giros de nossa centrífuga. Reiteramos este movimento, pois somente através dele é possível separar as fases. Como no sangue em que separamos o soro do tecido sanguíneo.

Obviamente que apesar destas críticas, o "Rede de Telas" teve e tem seus sucessos, como indicar possíveis políticas públicas que contemplem novos protagonistas audiovisuais e também uma proposta de discussão audiovisual enquanto espectador que pode ser realizada no âmbito do ensino médio, por exemplo. Além disso, o projeto fomentou dissertações e teses acadêmicas como a dissertação de Ananda Stücker sobre a periferia retratada nas séries televisivas Cidade dos Homens e Antônia e a livre docência de Esther Hamburger "Da política a poética de certas formas audiovisuais". Mas seria leviano novamente se silencias e não apontar, enquanto execução do projeto, que houve sim estas mesmas tensões histórias destes lugares em que seus participantes habitaram. Acredito que um exemplo muito latente é do grupo Núcleo de Comunicação Alternativa, que foi convidado naquela reunião sobre o início do "Rede de Telas". Este grupo tem suas produções audiovisuais estudadas como tema de mestrados e doutorados na FFLCH, mas os integrantes deste coletivo nunca estudaram numa universidade pública, apesar deles terem tentado muitas vezes prestar o vestibular da Fuvest.

Torço para que a filha de Tio Pac (uma adolescente preta) e sua geração, ainda nesse lugar periférico, possam futuramente estudar numa USP e dialogar com 
uma FAPESP sem que necessariamente tenham que lidar em seu ensino público diversos códigos vestibulares embranquecedores nos quais está lá a história construída num ponto de vista quase sempre do colonizador. Tomara que ela e esta nova geração não tenham que silenciar sua negritude para assim construir alguns diálogos possíveis sem que sejam julgados, no mínimo, inconvenientes ou necessariamente que seus protagonismos sejam somente validados se vier sob a tutela de algum branco na branquitude.

Tendo em vista as dificuldades cotidianas na relação dos grupos com a universidade e principalmente na dificuldade em público; em 2008, O Rede de Telas tomou a direção em trabalhar com os alunos do EJA nos mesmos bairros da Cidade Tiradentes e Jardim São Luís. As parcerias estabelecidas foram através de duas grandes escolas municipais de São Paulo que funcionam como centro de referencia educacional e de lazer nos bairros periféricos onde elas estão. Elas se chamam CEU - Centro Educacional Unificado e, no caso, os CEU's escolhidos foram o CEU - Casablanca, no Jardim São Luís - Zona Sul de São Paulo e CEU - Água Azul, na Cidade Tiradentes - Zona Leste de São Paulo. Nestas escolas existem auditórios muito bem estruturados semelhantes a sala de cinema com proteção acústica e luz controlada; foi a condição ideal para exibição de filmes e, consequentemente, para atividades deste projeto.

Neste outro vínculo, foram exibidos para o público do EJA filmes famosos ou mais conhecidos como Os Dois Filhos de Francisco e Antônia, filmes não tão conhecidos de um grande público como os documentários Moro na Tiradentes (2007, Henri Gervaiseau) e Notícias de Uma Guerra Particular (1999, João Moreira 
Salles) e filmes mais antigos como Eles Não Usam Black Tie (1981 - León Hirszman). Nas reuniões entre representantes do "Rede de Telas" e os professores destas escolas, elegemos que o público a participar destas exibições era preferencialmente os alunos do EJA que tem em si uma heterogeneidade no que diz respeito às variadas idades de seus integrantes (contempla adolescentes e adultos). Além disso, as sessões fossem abertas para qualquer pessoa e a partir delas os professores trabalhavam questões sobre os filmes antes e depois em sala de aula

Ao final das exibições, professores dos alunos do EJA iniciavam uma discussão sobre o filme exibido e ela era compartilhada entre o público e os pesquisadores. A partir de Junho de 2008, eu conduzi as discussões que haviam após as exibições dos filmes. A princípio havia um descompasso entre o "início de conversa" dos professores com alunos e o desejo na abordagem de algumas questões por parte da pesquisa no projeto. Algumas vezes, eu sentia que a discussão se iniciava através de uma visão dicotômica "bem versus mal" sobre os personagens e isto não cabia dentro do propósito do projeto, uma vez que desta maneira não se aprofundava a discussão e realmente não estávamos ali para demonstrar o que é bom e o que é mal para ninguém. Para tanto, nas exibições eu decidi apresentar o filme que seria assistido e depois conduziria a discussão sobre a obra de maneira que ela passasse nos temas e nas abordagens sobre representação da periferia, deixando sempre a possibilidade de algum dos espectadores relembrarem passagens do filme com as quais ele ou ela tenha se identificado. Pensei também em poder ser um exemplo positivo para alguns alunos do EJA; ou seja, um sujeito negro que está na universidade e que dialoga em sensibilidade periférica e negra com o público em diversos temas cinematográficos. 
Realizar este diálogo que colocava a universidade e a periferia em relação também foi tenso. Lembro que ao exibir Notícias de uma Guerra Particular no CEU Água Azul, eu perguntei, numa consciente provocação, qual era o paralelo entre o filme e a Cidade Tiradentes. Muitas pessoas do público ficaram indignadas com a pergunta comparativa e para tanto, algumas senhoras alunas do EJA elencaram diversos progressos econômicos do bairro. Neste sentido, o fato das Casas Bahia, Lojas Marabraz e o supermercado CompreBem terem se instalado no bairro, foi indicativo para se reiterar a distância entre o cotidiano da Cidade Tiradentes e o retrato realizado em Notícias de uma Guerra Particular, distancia esta que denotava evolução do bairro por parte dos presentes.

Entendi com esta resposta que o cansaço na recorrência em tais retratos periféricos não era somente meu, mas também de outras pessoas que também moram na periferia. Assim como no filme sobre o Promessinha se chamar "A Cidade Ameaçada", fica a sensação de que há certas recorrências se pensarmos quem tem a autoridade para falar sobre e pela periferia. Nas considerações de um outro rapaz aluno do EJA, ele relativizou dizendo a importância de um filme como "Notícias..." questionar a situação do comércio de drogas e a violência decorrente desta atividade, mas ele destacou também seu desconforto com retratos que frequentemente vinculam espaços periféricos a violência. Quando as senhoras disseram sobre os progressos da Cidade Tiradentes, entendi nelas um desejo de igualdade. O bairro ali já tinha, pelo consumo, a presença daquilo que é resultado da batalha de cada um: a dinamização e a transformação contínua da Cidade Tiradentes. Por mais que se possa questionar este crescimento pelo consumo, com 
donos(as) de lojas e estabelecimentos que não são do bairro, ali elas expuseram um desejo de dizer que somos muito além daqueles retratos oferecidos em Moro na Tiradentes ou em Notícias de uma Guerra Particular. Para mim ficou notório que geralmente a fala audiovisual sobre a periferia, dependendo de quem a profere, aprisiona e fecha o assunto. Encerrado muitas vezes num rosto negro trágico ou sem saída que melhor explica a situação cativa.

Como as "marcas do plural", para usar a expressão de Memmi, projetam os povos colonizados como "todos iguais", qualquer comportamento negativo de um membro da comunidade oprimida é imediatamente generalizado como típico, algo que aponta para uma eterna essência negativa. As representações, portanto, se tornam alegóricas: no discurso hegemônico todo papel subalterno é visto como uma sinédoque que resume uma comunidade vasta, mas homogênea. (Shohat e Stam, 2006, p. 269)

Nas exibições do "Rede de Telas" ficou pungente essa dimensão do espectador naquilo em que ele absorve ou não do retrato da periferia. Enxergar-se como possível foi, para algumas pessoas do público das exibições, elencar as conquistas de consumo que a Cidade Tiradentes obteve. Mas se as representações alegóricas do subalterno atuam como sinédoque (como Ella Shohat e Robert Stam desenvolvem), é possível questionar se estas pessoas se identificam com personagens negros tendo em vista que a maior parte dos filmes que retrataram periferia trabalha personagens negros vinculados a processos violentos. Uma Onda no Ar, Ônibus 174 (2003, José Padilha), Quase dois irmãos (2005, Lúcia Murat), Carandiru (Hector Babenco, 2003), Cidade dos Homens, Última Parada 174 (Bruno Barreto, 2009), Antônia; todos eles trazem pelo menos um personagem negros vinculado, de alguma forma, com a violência; sejam protagonistas ou personagens secundários. Será que retratos recorrentes do negro vinculado a violência ou a 
condições sub-humanas são capazes de fazer com que os espectadores não se identifiquem com personagens negros não necessariamente vinculados a violência? Será que estes retratos recorrentes do negro e da negra no nosso audiovisual fazem com que a pessoa também negra se enxergue numa imagem branca através de personagens brancos (estes sim) que exprimem humanidade?

Aos que não ficam convencidos, aconselhamo-vos a seguinte experiência: Assistir a uma projeção de um filme do Tarzan nas Antilhas e na Europa. Nas Antilhas, o sujeito negro se identifica de fato com o Tarzan e é contra os negros. Em uma sala cinematográfica europeia, isto é mais difícil porque o público branco o relaciona automaticamente com os selvagens da tela. Esta experiência é decisiva. O Negro, sente que não é negro impunemente. (Fanon, 1973, p. 127). ${ }^{23}$

Em agosto de 2008, o projeto "Rede de Telas" exibiu o filme Saneamento Básico (2007, Jorge Furtado) no CEU - Casablanca. Nele há dois personagens negros representados pelos atores Camila Pitanga e Lázaro Ramos. Na discussão do filme não houve menção a fatores qualitativos das personagens negras, o que foi relembrado do filme foi o contexto em que na trama se realiza um filme amador que tem um intuito de ser um facilitador das obras de canalização do esgoto que cai diretamente num arroio (riacho) da região. No final dessa história do filme, o mesmo riacho permanece poluído e o filme se torna sucesso. Talvez não comentar sobre os atores negros já seria um passo no reconhecimento de outros papéis possíveis para o negro e a negra. Por outro lado, este filme pode caminhar em algo semelhante ao que Stuart Hall colocou sobre a presença da diferença não produzir diferença alguma. Se no projeto houvesse algum exemplo de exibição de filme em que o

23 "A los que no queden convencidos los aconsejamos la experiencia siguiente: asistir a la proyección de una película de Tarzán en las Antillas y en Europa. En las Antillas el muchacho negro se identifica de facto con Tarzán contra los negros. En una sala cinematográfica europea esto es más difícil porque la asistencia, blanca, lo relaciona automáticamente con los salvajes de la pantalla. Esta experiencia es decisiva. El negro siente que no se es negro impunemente". (Fanon, 1973, p. 127) 
personagem principal negro não estivesse necessariamente vinculado a violência (Como os filmes Cafundó, 2005 - Paulo Betti; Besouro, 2009 - João Daniel Tikomiroff ou Proibido Proibir, 2006 - Jorge Durán), talvez seria possível elaborar respostas a esta indagação que está atrelada ao reconhecimento do negro na branquitude como um processo de se enxergar humano em suas possibilidades.

Nas exibições para o público do EJA, eu tentava correlacionar a presença de personagens negros nestes filmes com o debate sobre a trajetória deles. $\mathrm{Na}$ exibição do filme Antônia tentei realizar isto e o público do EJA no CEU-Casablanca destacou positividade no retrato das personagens principais deste filme. No entanto as respostas do público do EJA foram enviesadas pela presença de uma das atrizes do filme na discussão, no caso a cantora e atriz Quelynah (convidada pelo projeto para a exibição) se comportou como uma Celebridade que veio oferecer sua caridade ao público de periferia. O filme Antônia foi elogiado por mostrar uma história superação das quatro cantoras, por outro lado não houve questionamentos sobre as personagens se elas confrontassem, por exemplo, algum outro espaço disputado. Nos elogios destinados ao filme e a beleza da cantora Quelynah, a qualidade das protagonistas estavam vinculadas ao talento nato para o canto e não tanto para algo aprendido ou vivenciado culturalmente.

Nas grandes produções audiovisuais nacionais (novelas, séries televisivas nacionais, fílmicas), geralmente a pessoa negra é invisibilizada, estereotipada ou realiza papéis que evocam subalternidade; no entanto, nas grandes produções audiovisuais que retrataram espaços e personagens periféricos, os protagonistas foram na maioria negros, mas também frequentemente estereotipados. Quando eles 
lutam contra sua subalternidade, pode lhes restar a morte brutal muitas vezes. Quando vencem, é porque ocupam um lugar pré-determinado ao negro em nossa sociedade, como uma característica nata do(a) próprio(a) protagonista. Há algo recorrente em obras audiovisuais que trabalham protagonismos negros: a inclusão numa subalternidade determinada por uma normalidade oriunda da branquitude .

Neste projeto, lembro que lancei uma pergunta a um garoto aluno do colegial noturno do CEU-Casablanca, ele é negro e devia ter uns 16 ou 17 anos. Eu perguntei algo que dialogava sobre a frequência de certas representações dos personagens negros nos filmes Cidade de Deus e Tropa de Elite; lembro que sua resposta indicava uma solução que caminhava na trajetória pessoal da pessoa. $\mathrm{O}$ que ela decidir pra si é o caminho que a fará, de alguma forma era essa a ideia. Lembro que para isto, este garoto exemplificou sua própria experiência num curso de gastronomia que fazia no $\operatorname{Senac}^{24}$. Ele, inclusive, já trabalhava na área, num restaurante de relativo conforto, para um chefe "do lado de lá da ponte" (sic). Conversando reservadamente com este garoto, entendi que ele se dedicava muito a empresa onde ele estava e desejava trabalhar sempre para seu patrão. Ou seja, o garoto trazia um discurso semelhante ao processo de um "self-made-man" 25 , que traz em si a marca de protagonismos, e ao mesmo tempo o conforto e a necessidade de enxergar um futuro subalterno nesse período de sua vida. Em Tropa de Elite, o personagem André encontra possibilidade de exercer sua profissão policial no Batalhão de Operações Especiais da Polícia Militar do Rio de Janeiro,

24 SENAC é a sigla de Serviço Nacional de Aprendizagem Comercial, instituição de educação profissional que realiza diversos cursos profissionalizantes gratuitos e mantém faculdades com diversos cursos em graduação e pós-graduação.

25 Self Made Man é uma expressão utilizada nos Estados Unidos. Sua tradução literal do idioma inglês é: "O Homem que se faz" e se relaciona com a capacidade empreendedora do indivíduo. 
mas tanto em Tropa de Elite quanto o Tropa de Elite 2, André permanece subalterno e tutelado pelo Capitão Nascimento e de seu tutor, André aprende os mesmos instrumentos de tortura policial. Tropa de Elite não foi exibido no projeto, mas ele foi mencionado quando o "Rede de Telas" exibiu o documentário Notícias de uma Guerra Particular. Apesar do sucesso de um filme como Tropa de Elite, ao perguntar para a plateia se desejavam assistir a este filme numa próxima sessão, a plateia ficou dividida. Os mais jovens queriam assistir a este filme, uma vez que boa parte deles já tinham assistido e gostavam muito das cenas de ação nas quais Capitão Nascimento resolve a sua maneira o confronto contra a criminalidade. Já os mais velhos e os professores não queriam a exibição do filme porque não queriam mais uma vez atrelar juventude da periferia ao retrato da violência aliada ao tráfico de drogas. Há um conjunto de experiências que entram em interlocução no diálogo que se estabelece com a obra audiovisual exibida.

Nem o texto, nem o espectador são entidades estáticas, préconstituídas: os espectadores formam e são formados pela experiência cinematográfica dentro de um processo dialógico infinito. O desejo cinematográfico não é apenas intrapsíquico, mas também social e ideológico. Nesse sentido, a noção de Stuart Hall de "leituras negociadas" (com base na classe e na ideologia) pode ser estendida às questões de raça e etnia. Poderíamos falar então sobre leituras "dominantes", "resistentes" ou "negociadas" racialmente. (Shotat e Stam, 2006, p.458)

No "Rede de Telas", as leituras negociadas estavam presentes nas discussões seja para contestar ou para validar o filme exibido. Neste sentido, foi bastante importante a última exibição do projeto Rede de Telas, no CEU - Água Azul, com o longa metragem Os Dois Filhos de Francisco (2006, Breno Silveira). Não houve discussão após a exibição deste filme devido a atrasos na projeção, no entanto, estava evidente a manifestação positiva do público do EJA enquanto Os 
Dois Filhos... era exibido. O filme, que traz a trajetória de vida e de sucesso da dupla de cantores sertanejos "Zezé di Camargo e Luciano", dialoga com uma história de superação de uma família migrante vinda de uma região rural para a cidade. Esta família mantém a crença em seus sonhos (Principalmente o sonho do patriarca em tornar realidade as carreiras musicais de seus filhos). Para mim, depois de ter acompanhado exibições de diversos filmes que dialogavam com espaços e protagonistas periféricos, compreendi que o sucesso de Os Dois Filhos de Francisco para os alunos do EJA não se dava apenas pelo resultado de um sucesso oriundo tão somente do talento musical de Zezé e seu irmão. Obviamente que o modelo desse sucesso, mote do filme, deve ser problematizado, pois poucos 'vencem' na carreira musical. Mas mais que o resultado, percebo que o impacto do filme se dá pela trajetória destes migrantes que não se esmorecem e se realizam enquanto sujeitos possíveis naquilo em que suas capacidades e seus talentos os dignificam. No caso de Zezé, seu talento foi aprendido a duras penas com o acordeon desafinado e também através da ingestão de ovo cru para ter uma voz bonita de cantor. Sem dúvida é um diálogo com a auto-estima de muitas dessas pessoas que migraram para as capitais ou com os(as) descendentes delas. É uma identificação com a própria capacidade protagonista do publico e dos personagens.

Destacar esta trajetória de sucesso neste filme não é assumi-la como modelo único possível para futuras produções que venham a focar personagens e espaços periféricos ou mesmo aquelas que sejam realizadas através de cineastas que se coloquem como periféricos politicamente. Para mim, a experiência do projeto Rede de Telas, ao terminar o ciclo de projeções com Os Dois Filhos de Francisco, mostrou a necessidade de haver histórias que possam dialogar entre o sujeito da periferia e 
sua trajetória que evoque facetas de "batalhas diárias" ao se fazer protagonista. Além disso, há outra questão a ser discutida nesse protagonismo que é o quanto negamos ou assumidos negros. Como se dá essa negociação identitária enquanto negação e afirmação dentro de um contexto de branquitude normativa? Fica o desafio em questionar estabilidade do discurso da mestiçagem que arrefece as tensões em critérios de raça e identidade negra.

Em 2008 o "Rede de Telas" terminou suas projeções e em 2009 houve a produção de relatórios e de vídeo-documentário sobre as projeções realizadas no ínterim do projeto. Há que se destacar nesse projeto os diálogos estabelecidos para execução do projeto em si (como a interlocução entre a USP e as Escolas municipais CEU). Ficaria feliz se a presença da USP nessas escolas CEU pudesse plantar sonhos em alguns de seus alunos ou alunas para que em breve estas pessoas contribuam no espaço universitário. O projeto foi importante em trazer tais diálogos e propostas entre pesquisadores e pretensos objetos de estudos. A periferia seria objeto de estudo? Os Alunos do EJA? Realizadores(as) periféricos(as)? Talvez foram, mas o mais doloroso foi (e é) vivenciar a distância simbólica que há entre a periferia e a universidade. O Departamento de Cinema, Rádio e TV continua ocupado por pessoas que não são da periferia. Quase não há negros lá. Mas a produção do filme Jennifer, por exemplo, já indica algumas possíveis pontes entre a universidade e a periferia.

O projeto "Rede de Telas" contribuiu de maneira significante no que tange a compreender ainda mais as políticas de representação da periferia e de seus moradores; proporcionando uma noção pela qual é muito necessário produzir 
audiovisualmente propostas que possam dialogar nesta questão. Assim, a conclusão do projeto "Rede de telas" dialoga com dois textos, um deles é a Tese de Livre Docência de Esther Hamburger:

A falta de futuro ronda a vida desses "outros", moradores de comunidades no morro e na periferia, onde não há sala de exibição de cinema. Mas é justamente pelo cinema que a falta de futuro dos moradores desses guetos assombra o universo restrito de realizadores e público de cinema, o que vem acompanhado de um discurso agressivo e contundente sobre as discriminações e desigualdades, em tom de ameaça que o rap expressa bem. Talvez também por intermédio do cinema possam surgir formas estéticas que ajudem a desarticular os estereótipos que aprisionam sujeitos discriminados em papéis sociais cujas condições de superação estão dadas. Não pelas pequenas benesses oferecidas pelo tráfico, mas pelas conquistas democráticas acumuladas ao longo de décadas por movimentos sociais e políticos que não estão organicamente presentes. Resta saber se haverá energia política e estética para inventar novas formas compatíveis com os desafios postos pelas atuais crises. (Esther, 2009, p. 569)

O outro é a Dissertação da cientista social Ananda Stücker:

Enquanto as contradições dos fenômenos representados e da própria representação não forem de fato encaradas, os projetos audiovisuais em torno da periferia se constituirão enfraquecidos justamente naquilo em que se propõe, como debate incisivo acerca da realidade social. É inegável a importância que tais programas adquirem no cenário audiovisual brasileiro e $O$ avanço que promovem no enfrentamento de problemáticas tão caras ao debate social contemporâneo. A interlocução que estas produções estabelecem umas com as outras e com uma esfera de discussão pública mais ampla tem uma contribuição de grande valor para o acirramento do debate. Mas os avanços políticos devem ser reconhecidos sem que se perca de vista o horizonte mais radical da crítica. Permanece assim candente como questão a busca de um projeto audiovisual atento ao dilema da representação do outro que responda à demanda de uma reflexão contundente do quadro político social da conjuntura atual. (Stücker, 2009, p. 124).

Vivenciando esta demanda na academia e dialogando intensamente com diversas manifestações de cultura na periferia (como os Sarais periféricos, por 
exemplo), eu percebi que poderia construir dramaturgicamente algumas respostas mediadas pela consolidação de diversos conceitos que circulam pelo multiculturalismo (Hall) e pela descolonização (Fanon). Ainda na segunda metade do ano de 2009, tive contato com literatura de autores como Achille Mbembe, Stuart Hall, o casal Ella Shohat e Robert Stam, Frantz Fanon... Autores que pensam a diáspora africana, o colonialismo, o eurocentrismo, estudos multiculturais. O contato com estes estudos se deu prioritariamente através da matéria "Raça, Sexualidade e Identidade Nacional" lecionada como matéria de pós-graduação pela Professora Doutora Antropóloga Laura Moutinho e pela Professora Doutora Ana Paula da Silva na Faculdade de Filosofia, Letras e Ciências Humanas. Tendo em vista as literaturas apresentadas e as discussões realizadas nesta matéria, comecei a correlacionar minha experiência enquanto cineasta/roteirista, universitário, morador de periferia e representações realizadas sobre espaços periféricos e pessoas que moram nela.

$\mathrm{Na}$ necessidade de realizar um texto provocativo acerca desta relação periferia-negro-universidade, dialoguei intensamente com os argumentos de Frantz Fanon nos livros "Pele Negra, Máscaras Brancas" e "Os Condenados da Terra". Minha base, no caso, partiu de estudos em relações raciais realizadas ainda em tempo de graduação e foi cultivado através de uma vivência em diversos sarais e encontros culturais periféricos. Como resultado disto, esta dissertação traz a dramaturgia da série televisiva "Menina Mulher da Pele Preta".

\section{Por que oferecer dramaturgias?}

Propor a construção desta série vem num sentido de afirmar-se possível na 
construção de significados. Aqui não é desejo de desprezar peremptoriamente toda e qualquer obra elencada aqui como não significativa no processo até de consciência pelo repetido fardo da representação. A metáfora trabalhada no sentido de demolição é necessária para desarticular as reiterações de discursos atrelados ao negro e a negra, sejam eles num sentido positivo ou negativo. Aqui não importa se a centrífuga também metafórica gira em sentido horário ou anti-horário, o resultado é que ela decanta forçosamente nossos espaços e nossas representações. A demolição simbólica foi necessária para construir obras audiovisuais numa visão crítica sobre as amarras de nossa branquitude. Mas agora chegou o momento de construir as propostas e, para isto, metaforicamente utilizarei uma espécie de Bulldozer, ou seja, um trator nivelador de terreno. Pretendo espalhar o material reciclado por este espaço resultante da demolição e elencar os materiais desta obra.

Assim, eu não questiono outro alguém falar da periferia, mas o que frequentemente me pergunto é: De que forma se legitima as vozes que sempre são autorizadas a falar sobre a periferia e com isso atrelar recorrentes imagens do que significa o negro e a negra em nossa sociedade? Quais formas de questionar esta autoridade e esta recorrência? Penso que a escritora Carolina Maria de Jesus oferece uma ótima resposta para isso:

"7 de Julho... Fui na dona Juana, ela deu-me pães. Passei na fábrica para ver se tinha tomates. Havia muitas lenhas. Eu ia pegar uns pedaços quando ouvi um preto dizer para eu não mecher nas lenhas que ele ia bater-me. Eu disse para bater que eu não tenho medo. Ele estava pondo as lenhas dentro do caminhão. Olhou-me com desprezo e disse: 
- Por eu ser de maloca é que você não deve mecher comigo. Eu estou habituada a tudo. A roubar, brigar e beber. Eu passo 15 dias em casa e quinze dias na prisão. Já fui sentenciada em Santos.

Ele fez menção de agredir-me e eu disse-Ihe:

- Eu sou da Favela do Canindé. Sei cortar de gilete e navalha e estou aprendendo a manejar a peixeira. Um nordestino está me dando aulas. Se vai me bater pode vir.

Comecei a apalpar os bolsos.

- Onde será que está minha navalha? Hoje o senhor fica só com uma orelha. Quando eu bebo umas pingas fico meio louca. Na favela é assim, tudo que aparece por lá nós batemos e roubamos o dinheiro e tudo que tiver no bolso.

O Preto ficou quieto. Eu vim embora. Quando alguem nos insulta é só falar que é da favela e pronto. Nos deixa em paz. Percebi que nós da favela somos temido. Eu desafiei o preto porque eu sabia que ele não ia vir. Eu não gosto de briga." (Jesus, 2010, p. 84)

Minhas questões na universidade e no audiovisual vão além de me colocar como autoridade única a falar sobre periferia; exprimo identidade negra e periférica na perspectiva de exercer meus olhares cinematográficos sobre diversas questões. Eu também tenho o direito de construir estes olhares e poder trocá-los com diversos espectadores. Não a toa que "Menina Mulher da Pele Preta", série televisiva que proponho, traz histórias que em que discuto significados de cinco mulheres negras diferentes que estão em espaços também diferentes: Periferia, Ambiente Empresarial, Estação de Trem, Agreste Baiano, Tribunal de Justiça. Não sou mulher, mas trago cinco histórias sobre cinco mulheres negras muito diferentes entre si.

Como roteirista e dramaturgo, minha função é contar história sobre outros a quem denominamos personagens. Nestes outros, eu estou lá em minha história, perspectiva artística e política. Nestes outros, as pessoas e ideias que me formam e 
que em mim dialogam estão lá através de suas histórias e de seus pontos de vista nas quais ressoam no que aprendo e naquilo que me identifico. A partir disto, refletindo questões sobre significados sobre a pessoa negra, comunidades negras, culturas negras em nossa sociedade e dialogando com minha história enquanto negro, universitário e construtor de histórias e imaginários; eu tento trazer minha contribuição num audiovisual precário, discriminador e estereotipador na representação da negra e do negro e em suas contribuições nos nossos 'contares' de histórias.

\section{1 - Menina Mulher da Pele Preta}

Atualmente, várias peças de propaganda de TV têm pelo menos uma pessoa negra no elenco apresentado. Na minha infância, em época de carnaval, várias passistas mulatas estavam na tela da TV. Naquele momento era a representação de suas possibilidades protagonistas em seus corpos e rostos negros, mas as emissoras televisivas e a própria organização do carnaval conseguiam girar a grande roda econômica deste evento através também do aprisionamento destas mulheres nas figuras de mulata. Não sei se seria como o mito da sensual moura mestiça que Gilberto Freyre coloca em sua obra "Casa Grande e Senzala", mas ao passar minha infância e adolescência nessa tão forte dualidade entre a invisibilidade da mulher negra e essa visibilidade controlada, eu penso nas diversas mulheres negras com quem convivo cotidianamente e como elas se relacionam com estas representações. O quanto se nega, o quanto se afirma serem negras e quando é interessante exercer estas identidades controladas... E como se dá esta negociação. 
Neste sentido, escrevi em conjunto com Carlos Pereira, um amigo arquiteto meu, ainda em 2005, as primeiras versões do então curta metragem Larissa S/A no qual eu trazia uma mulher negra executiva como protagonista. Primeiro, a ideia foi trabalhar a visibilidade desta mulher num lugar executivo/empresarial e problematizar o quanto Larissa agrega o discurso recorrente de auto-ajuda empresarial correlacionando-o com a temática da solidão da mulher negra nos relacionamentos amorosos. Naquele momento, acredito que buscava ter apenas a representação da mulher negra num outro lugar e pouco discutia a presença dela como executiva de uma grande empresa. Conforme as re-escritas deste roteiro, fui trabalhando sutilezas na representação desta personagem negra Larissa e o quanto pode ser perturbadora a presença desta mulher negra nesta empresa retratada.

Ao final de 2007 e começo de 2008, eu escrevi outro roteiro, num formato de média metragem, chamado "Jennifer", que traz a história de uma garota de 17 anos, filha de Vera, uma mulher negra, 38 anos, cabeleireira e mãe solteira. Jennifer é mais clara que sua mãe, mas herdou físicos negros. Jennifer é uma exímia manipuladora de softwares de edição de imagem e ao trabalhar as fotos de sua melhor amiga Thamires (a pedido da própria amiga), Jennifer começa a manipular suas próprias fotos e as posta em sites de relacionamento. A proposta neste roteiro é dialogar sobre a negação em ser negra protagonizado por uma pessoa que é filha de um processo embranquecedor.

No segundo semestre de 2009, quando realizava a matéria Raça, Sexualidade e Identidade Nacional, eu desejei escrever mais três ou quatro histórias 
com protagonistas negras para assim formar um longa metragem ou série televisiva com cinco ou seis histórias de mulheres negras protagonistas; seria uma resposta a suas invisibilidades e estereotipias no nosso audiovisual. Para isso, meu desejo foi realizar isto em parceria com mulheres negras artistas de meu convivo nos diversos espaços culturais periféricos. Primeiramente, procurei atrizes de duas companhias teatrais: Capulanas Companhia de Arte Negra e Grupo Teatral Clariô. No entanto, os inúmeros compromissos das atrizes destas duas companhias teatrais fez com que a procura de parceria encontrasse diálogo com outras duas autoras/poetas que são amigas minhas e que as conheço também através do cotidiano cultural periférico: a atriz/escritora Ana Paula dos Santos Risos e a jornalista/escritora Elizandra Souza. Com uma grande produção de poemas e contos, Ana Paula escreveu um conto chamado Estações de Transferência, no qual sua personagem Simone, uma jovem que trabalha como operadora de telemarketing, devaneia no momento em que espera longamente a chegada de seu namorado na catraca de uma estação do Metrô/CPTM. Reconhecida poeta negra no meio cultural periférico e do hip-hop, a jornalista/escritora/poeta Elizandra Souza escreveu o conto A Primeira Vez que fui ao Céu para o livro Um Segredo no Céu da Boca composto com outros(as) autores(as) periféricos e editado pela Edições Toró. Este conto traz a história de Dara, uma criança que mora no interior do Estado da Bahia e que pede para seu avô montar um balanço num forte galho de uma árvore de caju.

Ainda no final de 2009 , eu adaptei estes dois contos numa forma de roteiro cinematográfico. Estes roteiros têm substanciais diferenças em relação aos contos, "Estações de Transferência" não trazia a questão racial como foco e "A Primeira Vez que fui ao Céu" não se pautava na migração nordestina para a Cidade de São Paulo. 
Ao adaptá-los trouxe estas questões e subtextos. Fiquei feliz ao conseguir tais parcerias com Ana Paula e Elizandra porque elas são autoras de contos e textos muito bem articulados entre sensibilidade e narrativa; além disso, eu me sentia muito incomodado em conceber histórias femininas sendo eu um homem. Roteirizados e adaptados os contos, eu senti que ainda faltava pelo menos mais uma história em formato de curta ou média metragem para completar este projeto.

Há certo tempo, eu tinha uma imensa vontade de escrever alguma história, conto ou roteiro cinematográfico que homenageasse de alguma forma a juíza soteropolitana Luislinda Santos, de atuais 66 anos e que tem sua história permeada pela desconstrução da discriminação racial no campo judiciário. Para tanto, eu imaginei como seria para uma juíza negra julgar uma ré negra sendo que, de alguma forma, as duas passariam cada uma por experiências fortes e semelhantes. Ao assistir alguns filmes de Krzysztof Kiéslowski como "A Fraternidade é Vermelha”, "A Igualdade é Branca" e capítulos da série televisiva "O Decálogo", eu pensei em correlacionar as estruturas dramatúrgicas nestas obras e seus personagens com a proposta de compor uma história em que uma juíza julga alguém que viveu algo semelhante ao que ela presenciou. Através destes referenciais, ao final de 2010, escrevi o média metragem Deolinda. Nesta história, traço paralelos entre a personagem Cristiane; mulher negra de 24 anos, rainha da bateria da Escola de Samba Rosas de Ouro que trabalha como doméstica na mansão de um herdeiro da maior mineradora do Brasil; e a personagem Deolinda, que na época de sua graduação em Direito na USP, namorou seu professor de Direito Penal.

Com a confecção da história "Deolinda", consegui formar cinco histórias com 
cinco mulheres negras protagonistas e estruturá-las como longa metragem ou então como série televisiva de cinco capítulos. Nesta proposta, a sequencia das histórias fica na seguinte ordem: Jennifer, Larissa S/A, Simone - Estórias em Estação de Transferência, Dara - A Primeira Vez que fui ao Céu e Deolinda. A seguir, descrevo as construções dramatúrgicas e as referências de cada uma destas histórias.

\subsection{1 - Jennifer}

A ideia deste roteiro surgiu pela confluência de diversas histórias de mulheres da minha vizinhança na Vila Nova Cachoeirinha. Lembro que minha vizinha de bairro, na época com 15 anos, vivia as turras com seus cabelos cacheados aos quais sua mãe cabeleireira dedicava longas horas de alisamento. Esta garota tinha a pele mais escura que eu e ela se sentia feia, mas ao colocar suas fotos com cabelos lisos em sites de relacionamento como orkut, ela dizia se sentir mais bonita. Paralelamente a este cotidiano do meu bairro, eu realizava a matéria de Interpretação Teatral no departamento de Artes Cênicas da USP. Esta matéria era lecionada pela professora e atriz Patrícia Leonardelli e lá conheci a então graduanda em artes cênicas e atual atriz Juliana Rodrigues Valente Santana Nunes; através da amizade estabelecida com ela, tomei mais contato com sua história de vida e com seu trabalho em cena. A Mãe de Juliana é branca descendente de portugueses, o pai dela é negro do interior do Estado da Bahia. Juliana é filha de mestiçagem e a partir deste entrecruzar do meu dia-a-dia na quebrada com o cotidiano universitário (através de matérias que abordavam/problematizavam relações raciais e a vivência de pessoas próximas que negociavam-se negros ou brancos dependendo das 
circunstâncias), comecei a refletir como se dá e se exerce negações e afirmações de identidades negras feitas a partir de pessoas que são filhas de encontros denominados inter-raciais. Digo isto porque vivemos num contexto em que a mestiçagem é valorizada enquanto discurso arrefecedor de tensões sociais, mas pouco se discute qualidade destas escolhas e suas assimetrias de poder; afinal, uma nação se faz também na cama.

Perguntei para minha vizinha que alisava seus cabelos se ela se considerava negra, ela se sentiu ofendida com a pergunta e afirmou ser morena como sua mãe cabeleireira; para tanto, ela relembrou que sua avó é branca de olhos claros, esta avó é minha vizinha de bairro também. Ao mesmo tempo, conversando com Juliana, que tem a pele clara que esta minha vizinha, relatou-me alguns acontecimentos ocorridos com ela pelo fato dela ser filha de um encontro inter-racial. Dos relatos, o que ficou para mim é: independentemente da intensidade da cor da pele, a ideologia atrelada ao que significa negro na nossa branquitude se constrói, valida-se e reiterase. É uma negação embranquecedora baseada na branquitude e protegida na branquidade pela qual para se exercer a identidade negra, é necessário colocá-la em espaços definidos e delimitados muitas vezes por exotismos e estereotipias. Tendo esse contexto, caminhei para a dramaturgia e trouxe uma história em que faço um retrato intimista sobre Jennifer, uma adolescente de 17 anos, filha de mãe negra e pai branco. A mãe de Jennifer se chama Vera, ela tem 38 anos, é mãe solteira, baiana e trabalha como cabeleireira num salão de beleza do Bairro da Vila Nova Cachoeirinha, periferia da cidade de São Paulo.

Jennifer nasceu neste bairro, mas dos dois aos nove anos de idade, ela 
passou sua infância na cidade de Macaúbas, Estado da Bahia, onde morava com sua mãe e sua avó. Aos 9 anos de idade, Jennifer retornou a Vila Nova Cachoeirinha com sua mãe, Vera procurava melhores oportunidades no trabalho em salões de beleza da capital paulista. A volta faz com que Jennifer seja hostilizada na pequena escola particular onde ela estudava, seu sotaque baiano e seus cabelos grandes e cacheados eram motivos de chacotas; assim, Jennifer cresceu apegada ao seu universo interno que aprendera na sua infância do sertão baiano.

Introspectiva e observadora das pessoas a sua volta e de seu bairro, a já adolescente Jennifer deseja encontrar um namorado ou mesmo demonstrar que está disponível para se relacionar com alguém; desta forma, ela sente que deverá estar e ser mais mulher se quiser a realização destes encontros. Longe de ser boba, Jennifer quer se sentir possível para o amor, mas qual mulher ela será? Ela mesma ou o que ela pode construir de si?

Jennifer cresceu com a noção de que seus cabelos são ruins e que, de alguma forma, ela é ainda invariavelmente feia. Existe algum legado a se apagar para que ela seja aceita ou se aceite. Jennifer é mais clara que sua mãe, ela percebe que ainda algo Ihe falta para se entender bonita e viável como mulher. Ao frequentar e trabalhar como manicure no salão de beleza onde sua mãe trabalha, Jennifer vivencia um padrão de beleza que quase nunca leva em conta características da mulher negra. Sentindo-se feia, Jennifer vê que sua melhor amiga Thamires (morena clara, de 17 anos, cabelos lisos) sempre consegue alguém pra se relacionar. Para Jennifer, Thamires é uma possibilidade de beleza uma vez que a amiga parece ser mais resolvida com seu corpo e com os homens a sua volta. No 
entanto, ao retocar as fotos Thamires no computador, a pedido da própria amiga, Jennifer entende que destacar seios ou quadris em fotos já sensuais proporcionará um interessante passaporte para estar enturmada ou junta a quem ela ama, mas isto exige uma qualidade. Para exprimir seus mais sinceros sentimentos de amor, Jennifer sublinha sua herança branca para se tornar uma mulher possível no amor e não somente uma mulher utilizada assim como foi com sua mãe.

Construir outra imagem de si que permita sugerir outras identidades e que possa suprimir todas as frustrações que o rosto real confere. Além do filme questionar a branquitude através do ponto de vista de uma pessoa filha do embranquecimento, o filme Jennifer traz um feixe de acontecimentos e temáticas interligadas. Atualmente, por exemplo, adolescentes contam com diversos recursos da internet que possibilitam estar juntos a um grupo, um amigo ou mesmo a quem se ama. Para todos e para os jovens principalmente, Orkut, MSN, Facebook são espaços virtuais onde são possíveis melhorar uma auto-imagem que a própria pessoa tem de si e deixá-la exposta a todos; auto-imagem em estilo de vida ou mesmo em relação aos retratos que ela mantém em seus murais virtuais. Nas diversas questões identitárias que envolvem a passagem adolescente na vida de cada um, uma delas (o meu destaque) é entender como um discurso de embranquecimento também é exercido neste contexto, pois para mim é recorrente a aceitação pela negação do que significa negro, negociando-se o que há ou que ainda resta como significado branco.

Jennifer que num momento de sua vida em que começa a se afirmar como mulher, ela luta contra sua auto-estima que nega aquilo que herdou enquanto filha 
de negros. O desejo de amar (personificado pelo personagem Cauã, um rapaz de 17 anos, loiro, que estuda na mesma classe de Jennifer) e o ter que se portar em maneiras estanques para que encontros aconteçam trazem a Jennifer o hiato da solidão, como numa incongruência entre ser e se simular.

Assim, a sensualidade de Jennifer não é um sinônimo de feminilidade ou mesmo uma guinada na sua baixa auto-estima. Ser mulher para Jennifer é lidar com inúmeras contradições que a cerca. Ser também negra e ter milhares de artifícios para se negar isto. Ser mulher para Jennifer é se portar como mulher madura, digna para uma vaga de balconista num hipermercado, mas que ao mesmo tempo disfarça seus receios e seus vacilos em nome de uma segurança salarial libertadora. Dependendo do que se afirma enquanto negra ou branca, para uma jovem como Jennifer; Branca da terra, Moreninha, "Café com Leite"; existem diversas circunstâncias e contextos que podem colocá-la em estereótipos. Ao focar relações em ser ou não ser negra vivenciados por uma garota de pele clara com traços negros, emana-se de uma forma mais latente o trabalho no qual olhares e escolhas embranquecedoras são utilizados como discurso. Acredito que geralmente na relação estabelecida entre espectador e protagonista da pele preta, é comum o afastamento; ou seja, quando há estas histórias com personagens principais da pele mais negra, é muito comum que a interlocução entre espectador e personagem caminhe na representação do outro e somente deste outro; o outro utilizado como elemento de discurso para validar alguma denúncia social ou para tornar palpável a frustração de não termos chegado ao que significa o branco civilizado. Quanto mais negro, pouco há do jogo em se identificar consigo mesmo, denotando um espelho narcísico Branco, de fato. 
Trazer Jennifer como uma garota da pele bem preta com questões acerca de sua identidade negra, poderia cair na representação deste outro e não de si. Neste sentido, seria até leviano, pois como representar a negação em ser negra tendo uma Jennifer da pele bem preta? Isto seria muito confortável uma vez que não representaria a negação em ser negra e nem a negociação disto pelo ponto de vista de uma garota que é fruto da mestiçagem. Enquanto mestiça, Jennifer nega aquilo que ainda existe nela como negra e negocia o que de branco há no que significa seu corpo, seu rosto e suas oportunidades. A mestiçagem é um discurso nacional, unificador e apaziguador, mas sua existência nega as negociações do que significam branco e negro. Este é meu pilar em Jennifer, trabalhar a negação vindo através de um encontro de mestiçagem. Meu desejo é questionar o espectador o quanto ele negocia ser branco e ser negro, por isso preciso que ele não caminhe na sensação de representação do outro, mas dialogue identificando-se a si mesmo.

Nesta proximidade, em "Jennifer" proponho estar junto aos vacilos, olhares, o "ficar", o "ir embora", beijar ou recusar da personagem Jennifer... Detalhes... Sua dramaturgia não propõe construir discursos morais ou de verdades absolutas, ela apenas compartilha aprendizados e identidades que a protagonista Jennifer escolhe ao longo de sua jornada, não cabendo lugares comuns que a periferia ou a afirmação de sua negritude possam representar. Ao partir destas experiências próximas tanto no bairro onde eu moro quanto na universidade, eu procurei escrever no roteiro "Jennifer" uma história que se propõe a ser sincera e digna com diversas mulheres que vivem nas mais diversas periferias e que lidam com inúmeros significados atribuídos aos seus rostos e corpos. Assumir a Vila Nova Cachoeirinha 
como micro-cosmo desta história é a possibilidade de dialogar experiências singelas e profundas para as mais diversas periferias onde o filme possa ser exibido. Falar do nosso bairro e do nosso jeito de ser para o mundo... E assim trazer humanidade e reciprocidade aos olhos de Jennifer.

O episódio Jennifer foi o primeiro a ser viabilizado como produção audiovisual patrocinada pela empresa York S/A através da modalidade de renúncia fiscal estadual PROAC-ICMS ${ }^{1}$, pelo Programa de Valorização das Iniciativas Culturais da Secretaria de Cultura da Cidade de São Paulo ${ }^{2}$ e pela Pró-Reitoria de Cultura e Extensão Universitária da Universidade de São Paulo ${ }^{3}$. Anteriormente a esta produção, o projeto Jennifer, enquadrado como curta metragem Jennifer, foi selecionado para a segunda fase do edital Prêmio Estímulo da Secretaria de Cultura do Estado de São Paulo. A banca julgadora do projeto viu na escolha da atriz Juliana Valente, já enunciada em fotos que compunham o book do projeto, uma contradição na história construída uma vez que Jennifer da pele clara não sofreria o que o roteiro indica que Jennifer sofre. Para a banca, a atriz Juliana Valente é branca e mesmo argumentando que o foco da história se dá pelo fato de Jennifer ser mestiça, o projeto foi recusado.

Jennifer foi filmado em Setembro e Outubro de 2010 e contou com

1 PROAC-ICMS é uma modalidade de renúncia fiscal destinada a financiamento de projetos culturais. Dependendo do porte da empresa, ela pode oferecer de $0,075 \%$ a $3 \%$ do tributo estadual denominado "Imposto de Circulação de Mercadorias e Serviços" para projetos culturais. Em troca, a empresa obtém renúncia fiscal do mesmo valor.

2 VAl é a sigla de Valorização das Iniciativas Culturais e se trata de um edital oferecido pela Secretaria de Cultura da Cidade de São Paulo para grupos culturais periféricos. Seu teto no ano de 2010 foi de $\mathbf{R} \$ \mathbf{2 0 . 6 9 2 , 0 0}$ para cada projeto apresentado.

3 A Pró-Reitoria de Cultura e Extensão da USP recebe e apoia financeiramente projetos culturais que dialogam e oferecem cursos de extensão universitária. 
profissionais oriundos de realizações periféricas e também de ambiente universitário em Audiovisual. A realização teve suas tensões intrínsecas a filmagem de fato (como tempo de gravação e agendamento de algumas locações) e também não foi tão tranquila no núcleo de Produção e Arte/Figurino do filme. Na produção haviam assistentes de produção vindos de um contexto de classe média alta e elas eram lideradas por Viviane Ferreira, produtora executiva do filme, negra e proprietária da Odun Formação e Produção (empresa que produziu "Jennifer"). Em vários momentos alguns dos assistentes tensionavam sobre a competência de Viviane na condução do processo. Em relação a Arte/Figurino, a tensão se residia nos questionamentos sobre a competência de Bianca Bressanini e Jéssica Ramos, responsáveis pelo figurino. No caso, o filme "Jennifer" foi o primeiro trabalho delas numa obra audiovisual e isto foi um fator que pesou muito no cotidiano da relação entre o Núcleo Figurino e a Diretora de Arte Laura Carvalho, que partia do pressuposto que Bianca e Jéssica conheciam alguns métodos utilizados para a realização do Figurino.

Entre Novembro/2010 a Março/2011, ocorreu o período de edição do filme. Este processo foi realizado por Ricardo Saito, atual editor de imagens e antigo colega de graduação na ECA//USP, e posteriormente por André Luiz Teixeira Braz, também colega de graduação que fotografou este filme. Algumas cenas previstas no roteiro foram cortadas na edição e algumas delas não foram sequer produzidas. Estas escolhas se deram pelo progresso da narrativa e pelo desejo de encurtar a história que estava com 37 minutos num corte inicial. Passado a edição, o filme ficou com 29 minutos com créditos e em Junho de 2011, Jennifer foi lançado como média metragem e atualmente percorre tanto os espaços periféricos de exibição 
cinematográfica quanto espaços centrais para exibição destas produções como Cinemateca Brasileira. A seguir, imagens de cenas do filme:

\section{A atriz Gabriela Balmant à esquerda (Thamires) e a atriz Juliana Valente}
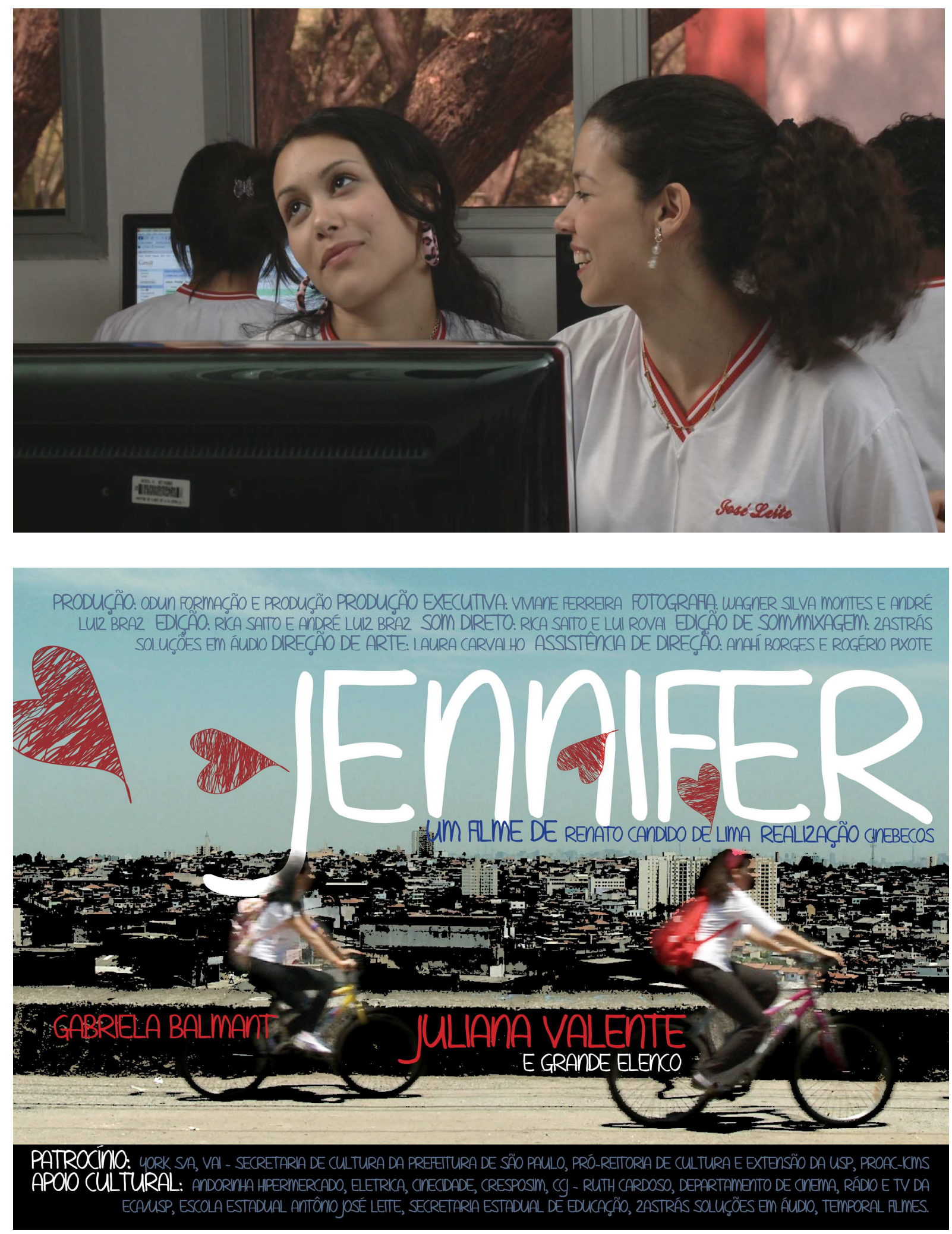


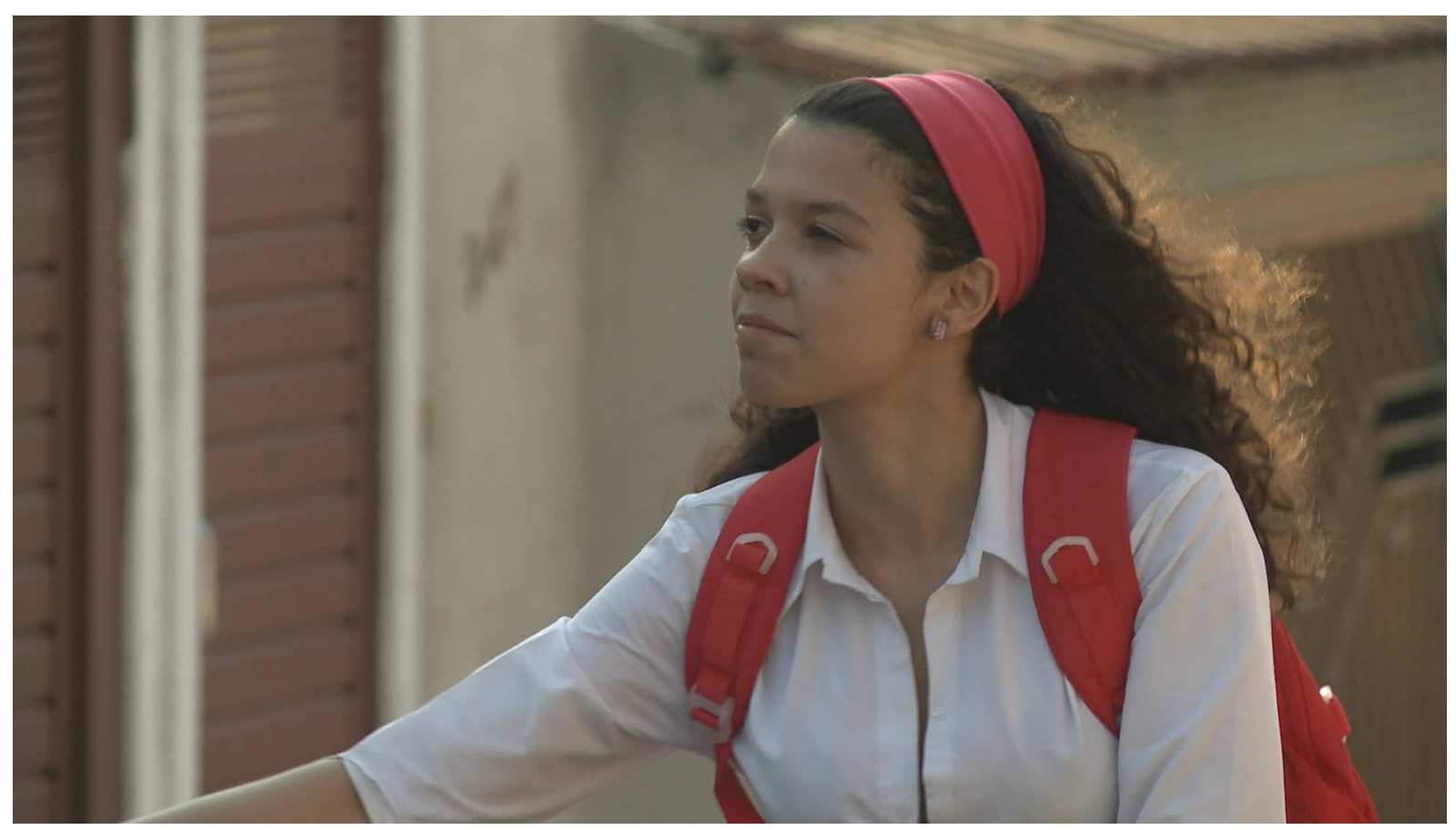

O projeto do filme incluía a realização de oficinas de linguagem cinematográfica (5 encontros) e interpretação teatral (10 encontros) para alunos da Escola Estadual Antônio José Leite, escola da Vila Nova Cachoeirinha (escola onde filmaríamos cenas do filme Jennifer). Os encontros de linguagem cinematográfica foram realizados na própria escola e foram lecionadas por mim; os encontros de interpretação teatral foram realizados, na maioria, no espaço do Centro Cultural da Juventude Ruth Cardoso pela atriz e graduanda em Artes Cênicas pelo CAC/USP Juliana Rodrigues Valente Santana Nunes. A diretriz das duas oficinas era possibilitar aos alunos algumas ferramentas de compreensão sobre Cinema e Interpretação Cênica. O vídeo das oficinas está no DVD em anexo a esta dissertação.

Nas quatro exibições veiculadas em Junho/2011, o público das exibições compreendeu, em maioria, o propósito do filme no qual Jennifer negocia aquilo que nela ainda há de negra e de branca em nome de um normativo branco. Muitas 
mulheres e jovens negras, ao final das sessões, disseram ter ficado muito emocionadas principalmente nas cenas em que a Mãe de Jennifer compreende aquilo que a filha está passando e em outra cena na qual Jennifer desenvolve seus pensamentos em que ela diz sobre si. Dia 21 de Julho de 2011, o filme Jennifer foi exibido na Fundação Casa de Internação Feminina do Bairro da Mooca. Nesta instituição, garotas menores de idade que cometeram delito cumprem a medida sócio-educativa estabelecida pela justiça ou aguardam julgamento de tais medidas. Lá, o filme Jennifer foi exibido para 160 internas e foi duas sessões de grande sucesso. A maior parte das garotas perguntaram porque o filme tinha acabado, uma vez que elas o acharam muito curto; pediram para mim que eu fizesse outro filme e exibisse na mesma instituição numa outra próxima semana. A boa aceitação do filme traz a sensação que ele tem cumprido seu propósito que foi trazer esta história para mulheres que de alguma forma se encontram ou se encontraram nesse processo de negociação em identidades brancas e negras.

\subsection{2 - Larissa S/A}

Nos anos de 1999 e 2000, eu trabalhei como técnico em telecomunicações. Eu instalava e realizava manutenção em centrais telefônicas privadas de atendimento e em PABX para grandes empresas situadas nos bairros dos Jardins (onde há o distrito empresarial de alto padrão da Avenida Faria Lima), Brooklin (Distrito Empresarial da Berrini), Granja Julieta (Distrito Empresarial Verbo Divino) e Morumbi (Distrito Empresarial da Chucri Zaidan). A empresa onde eu trabalhava prestava serviços para empresas de variados ramos, sendo mais frequente aquelas 
de tecnologia e de seguros. Eu não participava diretamente do cotidiano empresarial destas empresas, geralmente meu trabalho durava entre três a quatro semanas e finda a instalação do equipamento, eu partia para outra empresa. No cotidiano delas, eu me sentia um estrangeiro; ou seja, eu podia partilhar diálogos com boa parte dos funcionários, da limpeza a gerência (talvez a minha roupa social ajudava neste diálogo), mas nunca efetivamente eu pertencia a empresa. Sendo eu este "estrangeiro", alguns funcionários confessavam problemas de administração ou mesmo problemas de relacionamento entre funcionários na empresa que eu estava prestando serviço. Talvez como sabiam que eu iria embora em breve, estas pessoas relatavam estes problemas sem muitas delongas. Na maioria das empresas que frequentei, eu notei que a presença feminina era bastante desequilibrada nos cargos de chefia. Não era incomum relatos feitos na "hora do café" em que se julgos machistas ditavam a tônica da conversa. Algumas dessas conversas eram justamente protagonizadas por mulheres: "Fabiana veio com um decote desnecessário! O que ela quer? / Ela é muito burra, tá aqui pra dar pro patrão, cá pra nós!" Imaginei: Como ser mulher neste contexto? Nem elas se articulam politicamente para marcarem suas presenças!

Lembrei de uma empresa de consultoria jurídico-empresarial onde instalei uma central telefônica particular de grande porte. Um dos sócios-proprietários era uma pessoa muito grosseira, prepotente e arrogante com diversos funcionários e inclusive comigo. Ele tinha duas secretárias: uma senhora loira e uma jovem morena de cabelos lisos e de alguns traços negros (como nariz largo e pele escura, por exemplo. A moça era parecida com a famosa atriz Juliana Paes). Para a senhora loira, havia uma pilha de papéis aos quais ela se dedicava muito, seu telefone era o 
mais requisitado e foi um dos primeiros a ser colocado a funcionar. Esta senhora trabalhava sobrecarregada, por outro lado, para a jovem morena, pouco trabalho interno lhe reservava. Ao conversar com esta secretária, ela me disse que sua principal função era acompanhar o tal sócio-proprietário grosseiro em reuniões fora da empresa. Ela tinha maquiagem mais acentuada e usava decote mais aberto que a Senhora Loira. Na hora do café, diversos funcionários difamavam secretamente a secretária morena. Dividiam-na em decote, boca, pernas. Lugares que denotavam atributos físicos de mulata, mesmo ela não sendo uma mulata de fato.

Além dessas sutilezas, minha experiência ao atender estes clientes que eram empresas de alto padrão me propiciou também visões críticas sobre discursos executivo/empresarial que muitas vezes nascem envoltos através de manuais de auto-ajuda também empresarial/executiva. Numa desregulamentação da relação chefe/subordinado e também a não garantia de estabilidade no emprego em tempos denominados neo-liberais, houve uma profusão de livros-manuais nos quais existem uma série de regras para um novo tipo de relação pessoal intra-corporativa. "Dez maneiras de feliz no trabalho e na vida pessoal", "Casais Felizes enriquecem Juntos", "O Monge e o Executivo". Mas até onde se demarca a vida corporativa em relação a vida pessoal? Eu sentia um enorme descompasso no cotidiano dessas pessoas com quem eu conversava e que tinham cargos de gerência. Era muito forte a necessidade da diversão ser consumida a ponto de ser obrigatória nos finais de semana, como um absinto entorpecedor ou como uma compensação sobre o cotidiano semanal. Ao mesmo tempo, os significados de dedicação estavam atrelados a horas extras absurdas que passavam do expediente e adentravam finais de semana. A conciliação entre a vida pessoal e a competição empresarial é em si 
algo muito difícil, aceitar-se fraca ou fraco na vida pessoal/corporativa pode custar não só o emprego, mas talvez a carreira. Para isto, deve-se exercer o poder, mostrar sua liderança.

Esta experiência aconteceu comigo entre os anos 1999 a 2000, mas acredito que muitos fatos sejam diferentes atualmente. Por outro lado, assédios morais também se atualizaram, uma vez que ainda acompanho de alguma forma os cotidianos executivos de amigos e amigas que trabalham em ambiente corporativo. Para mim, as assimetrias dentro destes ambientes deveriam ser contadas em forma de histórias audiovisuais. Até que ponto uma vivência empresarial ou mesmo uma carreira executiva mescla suas urgências e padrões diferenciais com as vivências nas relações humanas? Como se dão as sutilezas discriminatórias em relação às mulheres num ambiente e num discurso executivo/empresarial/corporativo? Qual seria o mal-estar, ou quais seriam eles, se uma executiva negra liderasse uma equipe ou tivesse uma função centralizadora como $\mathrm{CEO}^{4}$ ou $\mathrm{ClO}^{5}$ ? Quais discursos que essa executiva negra assumiria para fazer valer sua competência e sua carreira? Quais incongruências entre sua vida executiva e seu protagonismo negro?

Diante destas questões, o roteiro de "Larissa S/A" traz as histórias de Larissa e Ricardo. Os dois foram vizinhos no bairro residencial de classe média da Lapa e vivenciaram uma amizade que migrou para um namoro ainda numa fase de transição da adolescência para juventude. No entanto, Larissa e Ricardo seguiram carreiras universitárias e profissionais em cidades diferentes; Ricardo foi para Belo

4 e $5 \mathrm{Na}$ atualidade do universo corporativo, executivo e empresarial, os termos CEO e CIO são amplamente utilizados. CEO é a sigla de Chief Executive Officer, que significa o cargo de Diretoria Geral de uma empresa; CIO significa Chief Information Officer e designa a pessoa responsável pela diretoria de tecnologia da informação de uma empresa. 
Horizonte cursar Engenharia Elétrica na UFMG e Larissa permaneceu em São Paulo para estudar Marketing numa grande faculdade particular. Esta separação de Ricardo e Larissa foi conturbada; o rapaz, ao escolher seu futuro como possível executivo de engenharia, elegeu o distanciamento da relação com Larissa como algo que naturalmente fazia parte desta ascensão. No dia de aniversário de Larissa, agora com 32 anos, o casal se re-encontra; Ricardo, 31 anos, agora é um engenheiro desempregado; Larissa se torna Presidente de Tecnologia da Informação (CIO) de uma empresa de softwares no distrito empresarial da Berrini.

Procurando por recolocação, Ricardo tem diversas desilusões em sua carreira executiva como engenheiro elétrico. Ele realizou quase tudo aquilo que o mercado condicionou: $\mathrm{MBA}^{\prime}{ }^{6}$, atualizações, liderou equipes, mas isto só encobriu incongruências, Ricardo não se encaixa neste discurso corporativo pronto para qualquer lição para sua vida pessoal. Larissa, pelo contrário, colhe resultados de sua dedicação ao trabalho e de seu esmero em seguir pessoal e profissionalmente diversas recomendações necessárias para seguir sua carreira. Assim como nos manuais de auto-ajuda executiva; para ela, o que vale é somente competência pessoal. Será?

Ao retornar de Belo Horizonte, Ricardo tem o desejo de reaprender algo que para ele "saiu dos trilhos". Ele descobre que Larissa irá se mudar de casa e que ela se tornou uma grande executiva. Ricardo sente um desejo de re-encontrar Larissa para Ihe pedir desculpas pela escolha falsa entre a profissão e ela que ele realizara em tempos de início de graduação, mas o desejo dele é principalmente se 
reaproximar dos sentimentos bons, vívidos e libertos que compartilhou ao estar junto com Larissa, namorando-a inclusive. No entanto, nada é tão enganoso, pois quando Ricardo a re-encontra, ele sente que não está ao lado de Larissa, mas sim a uma mulher que aprendeu muito bem os diversos mantras de auto-ajuda executiva e empresarial pela qual, a todo momento, necessita-se de soluções rápidas de mercado até para as frustrações na vida pessoal. Esse discurso responde a trajetória de uma mulher negra liderando um cargo de intensa responsabilidade?

O que explica a solidão de Larissa? E de Ricardo? Por que Larissa, uma mulher tão interessante, com um cargo tão importante, não encontra alguém do seu meio para se relacionar? Um homem branco se relacionaria com uma mulher negra detendo poder? Será que sua solidão como mulher negra a acompanha independentemente do cargo que ela exerce? E Ricardo? Ele idealizou Larissa quando elegeu seu significado enquanto mulher negra como retorno ao que ele havia desprezado em nome da ascensão pessoal em sua carreira?

Ao enxergar em Larissa uma mulher autômata de um discurso tão intenso, Ricardo se afasta dela. Larissa se vê numa nova solidão: seu aprendizado executivo não dá conta das frustrações e dos desencontros naquilo em que ser negra ainda possa representar. Larissa e Ricardo venceram enormes obstáculos ao exercerem suas competências, mas ao vencê-los, eles não se enxergaram mais como possíveis em si e entre eles dois. Ao procurar a negra Larissa e o negro Ricardo não fetichizados pela nossa cultura, tento trazer este cuidado com esta história a ser contada. Trago o belo, mas não o exótico para confrontar estranhamento e identificação no fruir destes personagens mediados por rostos e corpos tão pouco 
comuns no retrato desta classe média, no caso tão metodizada empresarialmente.

Em Janeiro de 2011, minha orientadora comentou que Larissa S/A é uma história que poderia ter personagens não necessariamente negros para representar esta dramaturgia. Concordo com ela e o ponto de partida deste filme dialoga com esta observação, no caso a proposta é trabalhar com atores negros que possam representar também estes papéis de classe média que seriam muito comuns a atores brancos. A partir disto, exerço sutilezas na interlocução entre os dramas dos personagens e os significados que eles estabelecem entre si enquanto pessoas negras. Assim, trabalho a identificação do espectador com os personagens numa chave pela qual qualquer rosto poderia ser para o drama em Larissa S/A e nisto introduzo questões relativas a representação do negro em relação a incongruências e a mal-estares destes protagonistas nesses lugares que eles ocupam.

O crescer do mal-estar envolto nas sutilezas é importante para que, ao final, ocorra a troca mais sincera possível entre Larissa e Ricardo, numa espécie de retirada e de subtração das inúmeras máscaras que se agarraram em suas peles. Despojados entre si, eles se re-encontram numa esperança mútua e sinérgica diante de um aprendizado não compreendido ainda... mas vivenciado, como num quente abraço numa fria manhã. 
A seguir, imagens de um ensaio fotográfico realizado em 2009 com atores do elenco de Larissa S/A:

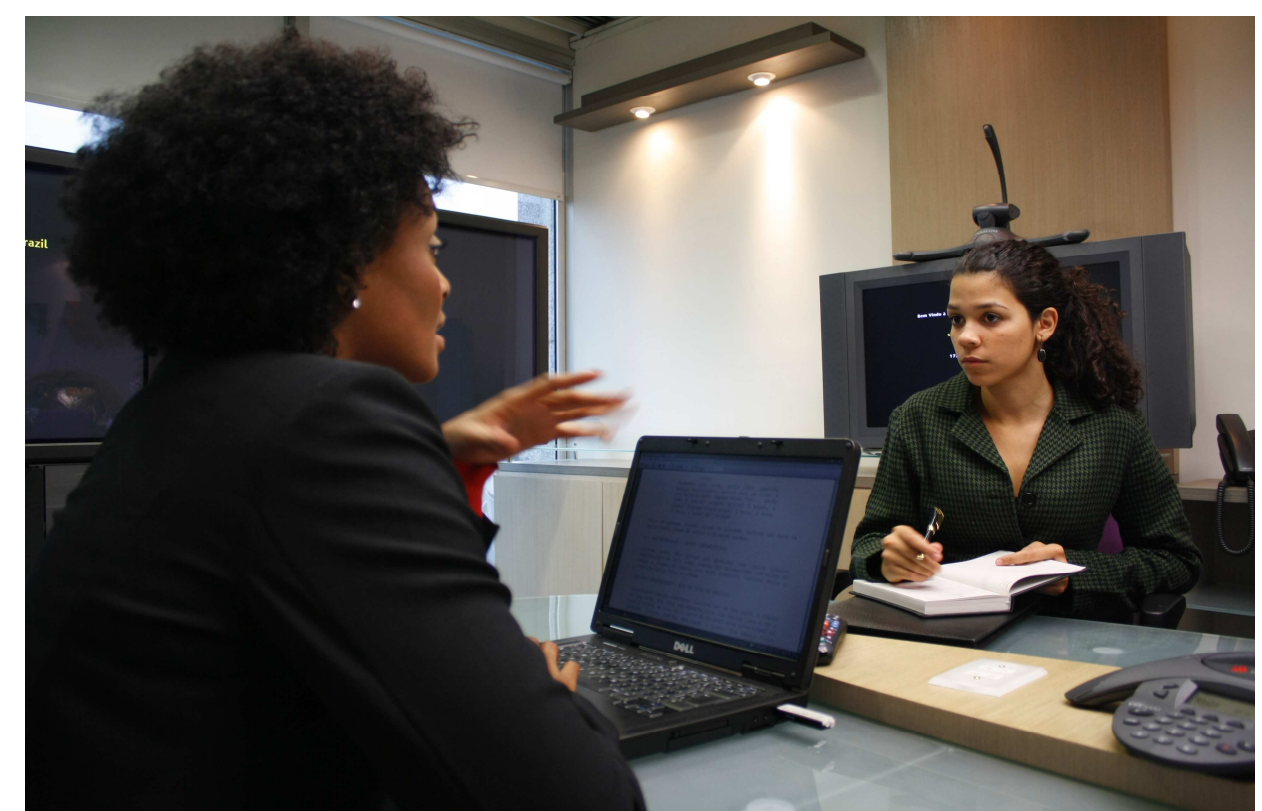

As atrizes Valquíria Ribeiro (Larissa) e Juliana Valente (Marcela).
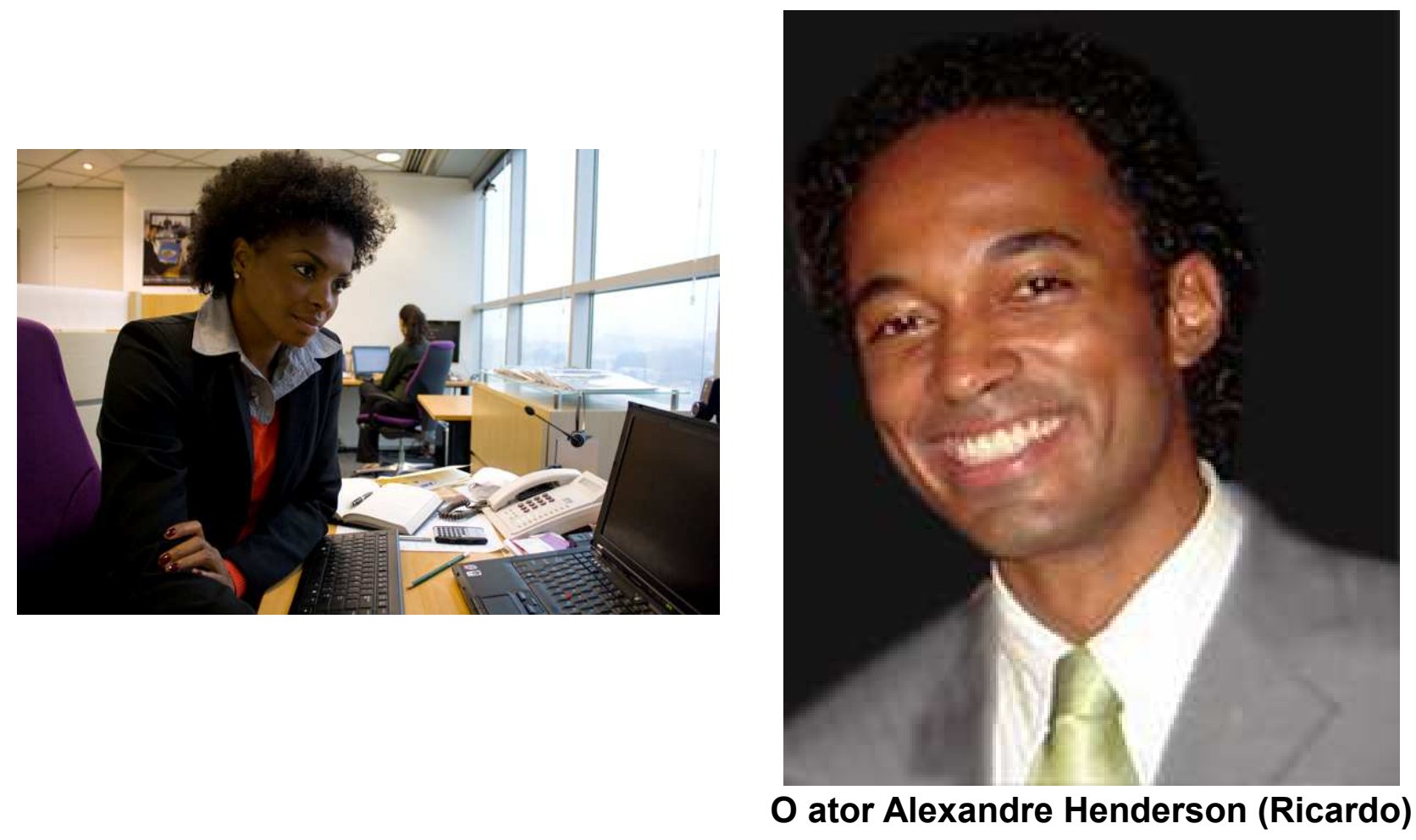


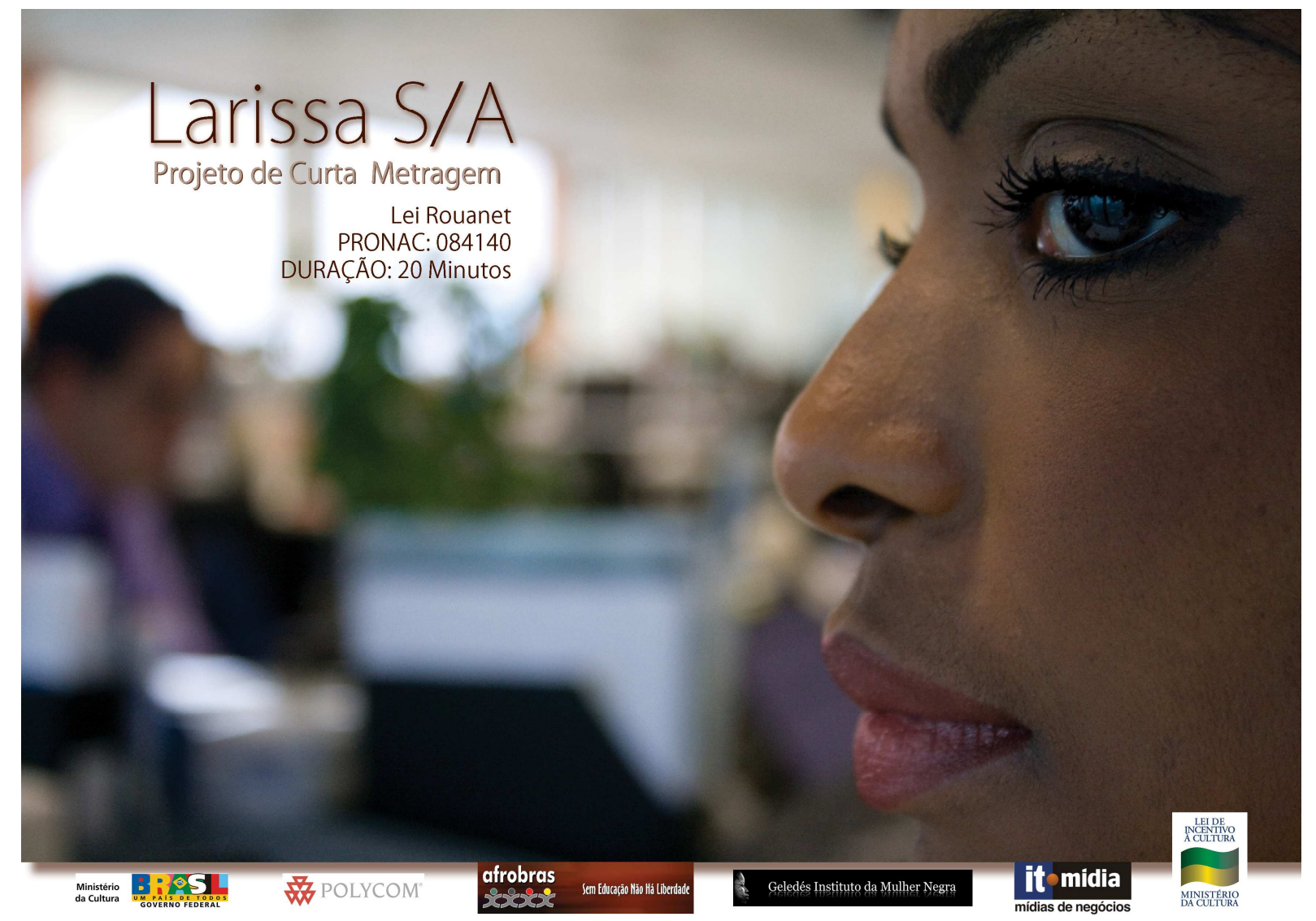

\subsection{3 - Simone - Estórias em Estação de Transferência}

Este episódio foi o primeiro escrito através de adaptação de um conto, para tanto o roteiro não é original. O conto adaptado se chama Estações de Transferência e foi escrito pela atriz, escritora e poeta Ana Paula dos Santos Risos. Ela realizou participação no filme Jennifer com a personagem Clarice, na cena do Salão de Beleza.

O roteiro adaptado traz Simone, uma jovem negra de 20 e poucos anos, moradora do Jardim Robru - Vila Curuçá, Periferia Leste da Cidade de São Paulo. Ela tem um dia decisivo para seu amor e, para tanto, a moça abdica do seu dia de trabalho como Operadora de Telemarketing para se encontrar com André, seu 
namorado até o momento, na Estação Brás, Transferência entre Metrô e Trem. A longa espera pelo namorado é permeada por pensamentos, realidades, ilusões e constatações nas quais esta jovem mistura ansiedades, reflexões, medos, mágoas, ressentimentos e dúvidas sobre sua identidade como Mulher Negra em nosso cotidiano. Nesta mistura, Simone nos leva a uma história que permeia ficção, imaginação e realidade sem fronteiras estabelecidas entre elas. Além de protagonista, Simone é quem também narra e conduz sua história, mesclando sua realidade e sua imaginação numa mesma ficção. Não temos duvidas sobre seu protagonismo, tampouco sobre suas ácidas reflexões.

Em Simone - Estórias em Estação de Transferência, sua dramaturgia trabalha o trânsito sem demarcações entre a realidade da personagem e sua imaginação. A espera por André, namorado de Simone (ele seria real ou imaginação dela?), denota diversas tensões acerca de suas invisibilidades e estereotipias como mulher negra possível para o amor, habitando assim uma encruzilhada em que o ideário de embranquecimento é tão presente em nossa sociedade.

O fervilhar das angústias, decisões e desejos de Simone é descoberto aos poucos pelo espectador; trabalhando assim no filme linearidades e não-linearidades do tempo narrativo que sugere, por exemplo, deslocamentos e mesclas entre o início e fim desta história (explicitado, por exemplo, pela indicação fotográfica esbranquiçada e pelo que Simone escreve em seu caderno dentro do trem). Além disso, cada vez que Simone parece despertar de seus pensamentos ao se situar na sua espera por André, elementos de realidade de Simone e de sua imaginação se misturam denotando o tempo subjetivo da protagonista. A espera para se afirmar 
como mulher negra possível em nossa sociedade é angustiante, mas essa possibilidade, naquele momento, vem de si própria; como num despertar consciente de Simone sobre suas fragilidades e sobre sua força. Passado, presente e futuro são vividos através do mesmo corpo e rosto negros de Simone denotando recorrências e mudanças naquilo que o corpo da mulher negra tem sido atribuído ao longo do tempo em nossa sociedade.

Há personagens não psicologizados que representam uma ideia de aristocracia colonial ainda atual; são figuras como Homem 4, Homem 5 e Mulher 3. A inspiração para esta representação aristocrata partiu da peça "Santa Joana dos Matadouros" de Bertolt Brecht principalmente através da figura do personagem Paulo Bocarra que, em seu jeito amoral, ele é capaz de tecer as mais ácidas considerações sobre a ingenuidade de Joana e sobre a realidade que os cercam. $\mathrm{O}$ personagem André, namorado de Simone, tem seu registro dramatúrgico variando entre o realismo e a representação arquetípica que lhe atribui, como homem negro, estereotipias de discursos poligâmicos e também em preferência por se relacionar a mulheres loiras. A proposta é trabalhar o conceito de Gestus $^{7}$ desenvolvido por Brecht para este trânsito protagonizado pelo personagem André.

“Simone - Estórias em Estação de Transferência” propõe um retrato em que a personagem não é vítima das circunstancias, mas sim ela se relaciona neste contexto através de seus desejos e de toda contundência de suas reflexões. Ao

\footnotetext{
${ }^{7}$ Gestus é um termo elaborado pelo dramaturgo e encenador alemão Bertolt Brecht (18981956) para discriminar a qualidade da representação de determinadas expressões humanas no palco. Não é apenas a simples gestualidade, mas a sim possibilidade de criar atitudes genéricas que os gestos podem demonstrar. Forma latina para designar gesto, na perspectiva brechtiana torna-se um conceito relacionado ao termo "gesto social", do mesmo autor, que abarca o tom de voz, toda a gestualidade, as atitudes, a vestimenta, enfim toda a caracterização da personagem pelo ator, objetivando uma leitura totalizadora da personagem.
} 
contrário do que seria comum associar esta personagem a um retrato de inexorável por vitimização em pobreza ou miséria, partilhamos no tom duro e direto o ponto de vista de Simone com toda sua verdade nas contradições de seus pensamentos e realidades.

A estrutura do roteiro de Simone se baseia no que seria o registro de um dia num hipotético diário da personagem principal. Assim como Carolina Maria de Jesus que escrevia sobre o universo de seus temas que variavam em assunto no registro de um dia do seu diário; Simone também registra suas angústias num diário seu. Como no diário de Carolina, em "Simone - Estórias em Estação de Transferência" toda vez que o assunto parece se modificar ou se resolver, o filme oferece uma próxima frase ou sequencia em que se contextualiza a não resolução das questões de Simone. No final da história, o que poderia ser somente a memória de um dia na vida de Simone, é indicado como o amadurecimento numa resposta forte e sincera consigo mesma como Mulher Negra. A contundência e a acidez no estilo da narração de Simone dialoga com o conto "Roselily" da escritora Alice Walker. Neste conto, a autora mistura prosa e poesia ao destacar os pensamentos de Roselily no momento em que ela está ao altar de matrimônio.

\subsection{4 - Dara - A Primeira Vez que fui ao Céu}

Nas diversas conversas que tenho com Elizandra Souza, numa delas eu revelei minha vontade em adaptar nas formas de roteiro cinematográfico muito de 
seus contos e poemas. Ao ler o conto A Primeira Vez que fui ao Céu, presente no livro Um Segredo no Céu da Boca e em seu blog "mjiba.blogspot.com', conversei com Elizandra a respeito de sua infância vivida na cidade de Nova Soure que fica no Agreste Baiano. O conto que deu origem ao roteiro é uma obra que parte da experiência da própria autora nessa relação. A autora, de atuais 28 anos, conta sua experiência ao balançar na sombra do cajueiro sob os cuidados e o empurrão de seu avô. É um conto simples do ponto de vista narrativo e repleto de significados e sentidos oriundos da diáspora africana.

Numa adaptação anterior realizei o roteiro tal qual como no conto realizava, ou seja, a história se focava na relação de Dara com seu avô na confecção do balanço e na sensação da menina ao brincar nos galhos do cajueiro. No entanto, relendo roteiro e o conto, decidi aprofundar o diálogo com a ancestralidade e algo inerente as migrações: o que se deixa e o que se leva. Trazer a migração como pano de fundo à história foi um desejo de revelar melhor um sub-texto no qual a própria autora do conto é migrante com sua família. Ao trabalhar isso de maneira mais forte, eu dialogo diretamente com histórias de muitos nordestinos que estão nas grandes cidades do sudeste e que, de alguma forma, colocaram-se na questão do que se deixa e daquilo que se leva. Do "passar o bastão" dos ancestrais até a nós e assim passarmos a diante. A própria resistência enquanto negros na nossa sociedade tem a ver com esta questão. Como, daquilo que se leva, transforma-se politicamente em resistência. Na tradição oral e vivida do candomblé, da capoeira, dos batuques, entre outros.

A Árvore, na cultura lorubá e no Candomblé, representa também o lugar onde 
ficam alguns orixás e ancestrais. Um exemplo, a árvore do Baobá é considerada sagrada por ser um elo entre o mundo e um outro plano, a longevidade desta árvore dialoga com a simbologia dos ancestrais assentados nesta árvore. Para "Dara - A Primeira Vez que fui ao Céu" resolvi tornar mais explicita a ligação do cajueiro presente na história com a representação dos Egunguns (ancestrais) que se assentam numa árvore.

$\mathrm{Na}$ identificação proposta desta interação com a migração nordestina, desloquei a temporalidade da história em Dara para os anos 60. Demarcando passado e presente, trago duas Daras, uma já senhora e a outra, criança. A ideia foi começar o filme com significados de retorno; ou seja, Dara senhora, em tempos atuais, retorna para aquele lugar e para aquele tempo em que há um balanço construído no cajueiro. Um retorno buscado e sentido. Como se a cidade de São Paulo não tivesse dialogado na essência de Dara.

O que se deixa, o que se leva.

Anos 60. As vésperas de migrar para São Paulo, Dara criança não demonstra preocupação em arrematar suas coisas para a viagem, ela quer sim levar consigo a sensação que um balancinho na árvore de caju, a maior que ela já viu, pode lhe trazer. Só que o balancinho ainda está por se construir e Dara ainda entrelaça as fibras das cordas da pequena tábua do balanço. Dara vai migrar com seus avós e suas irmãs porque seus pais já estão em São Paulo e recomendam em carta, diante das adversidades como sertanejo na Bahia, que a família toda venha para a grande capital paulista. 
Dara tenta montar sozinha seu empreendimento, mas não consegue diante da pouca experiência e ainda sofre a reprimenda de sua avó na tentativa solitária de balançar no cajueiro. Com a proximidade da viagem, o desejo de Dara fica cada vez mais forte em realizar seu vínculo naquela terra através do seu desejo de brincar na árvore. Somente na manhã do dia seguinte é que Dara, ainda tentando solitariamente montar o balanço, contará com a força e ajuda de seu avô. Ele ensina a Dara os passos e as maneiras para se montar um balancinho como aquele que a menina deseja. No entanto, o momento já de partida. Eles têm que ir a São Paulo, pois Zé do Caminhão, motorista da viagem, espera somente a família de Dara para completar a lotação do caminhão pau-de-arara.

Assim como na árvore que traz na sua forma o passado (raízes), presente (caule) e futuro (frutos e sementes), Dara traz em seus sentimentos esta árvore aprendida através de seus ancestrais. No roteiro, o momento focado é o re-encontro deste sentimento. Mesmo Dara sendo uma mulher que passou maior parte da sua vida na cidade de São Paulo, numa cidade na qual ela não vivenciará estes sentidos, ela ainda é capaz de sentir a ressonância destes legados. Mesmo tendo deixado o objeto balancinho em terras agrestinas na Bahia, o sentido desse movimento do balanço foi levado para si. Diferentemente dos outros capítulos nos quais problematizo a mulher negra em relação; em Dara, o que se coloca é uma faceta de sentidos em existência que no nosso contexto pode ser tomado como compreensão de maneiras possíveis nas quais resistências se constroem.

Este capítulo traz um diálogo formal em dramaturgia com filmes iranianos de 
cineastas como Jafar Panahi, Família Makhmalbaf e Abbas Kiarostami. Isso se dá principalmente no foco em realizar uma história muito simples que, pela singeleza, torna-se polissêmico nos sentidos que se atribuem na relação de Dara com sua família e o mundo a sua volta. Há referências indiretas a filmes como Através das Oliveiras (Abbas Kiarostami, 1994), em que uma mulher dirige um carro por uma estrada de terra numa zona rural do Irã; como o filme O Balão Branco (Jafar Panahi, 1995), no qual uma garota deixa cair para dentro de um bueiro o dinheiro para comprar um peixinho e para isso ela conta com a ajuda das pessoas que passam no local ou então como no filme O Silêncio (Mohsen Mahkmalbaf, 1998) que retrata a história de um garoto cego que trabalha afinando instrumentos musicais.

\subsection{5 - Deolinda}

Em Janeiro de 2010, eu li na Raça Brasil edição 138 uma entrevista concedida pela juíza de direito Luislinda Santos, de atuais 66 anos, uma das poucas juízas negras no nosso país. Na entrevista, Luislinda contou sobre sua trajetória para estudar na faculdade de direito e seus desafios como funcionária de tamanha importância dentro do poder judiciário. Meses mais tarde, li outras de suas entrevistas para revistas da Fundação Palmares, Revista Afirmativa, Portal Geledés, entre outros. Ao ler sua história, eu pensei como seria realizar um filme que contasse alguma passagem de sua vida.

Paralelamente a isto, eu aprofundava minha experiência na filmografia em documentários e ficções do cineasta polonês Krzysztof Kiéslowski. Em relação ao 
episódio "Deolinda", eu destaco parte de sua filmografia como as obras $A$ Fraternidade é Vermelha, A Igualdade é Branca, além de capítulos da série televisiva O Decálogo como Decálogo I - Amarás Deus sobre todas as coisas, Decálogo V Não Matarás e Decálogo VIII - Não levantarás falso testemunho. No filme $A$ Fraternidade é Vermelha, um dos personagens, o juiz aposentado Joseph Kern (Jean Louis Treintignant), descreve para Valentine Dussault (Irène Jacob), uma jovem modelo e universitária que encontra a cachorra perdida do juiz, um caso no qual ele teve um conflito ético. Trata-se de uma história em que este Joseph julgou um homem que, anos atrás, era amante de sua esposa. No filme, passado e presente de Joseph estão em diálogo e a maneira como se faz esta construção ao espectador nos dá a sensação de caminhar por histórias a princípio paralelas, mas que se entrecruzam num dado momento do filme. Kiéslowski não estabelece fronteiras entre as histórias dos personagens e suas temporalidades. Inclusive estas passagens, no filme, podem ser interpretadas como um outro núcleo de personagens do filme. Assim, a interligação das questões que o filme levanta advém dos significados intrínsecos construídos e sugeridos em cada sequência fílmica. Para a construção do episódio "Deolinda", fica a inspiração na forma com que se retrata a questão ética de Joseph Kern, o juiz aposentado, ao julgar alguém num caso em que ele mesmo estaria envolvido.

O filme A lgualdade é Branca é outra referência para a construção do episódio "Deolinda". Nesta obra de Kiéslowski, seu personagem principal, o cabeleireiro Karol Karol (Zgbiniew Zamachow), questiona em vários momentos a condição de igualdade nas circunstâncias que perpassam na sua vida. Seja no julgamento, no amor ou mesmo numa nova Polônia que se abre para a Europa do livre mercado. Eu 
destaco duas construções importantes deste filme na interlocução com o episódio "Deolinda":

Primeiro - Karol Karol, ao retornar a Polônia e especular sobre terrenos de uma área rural perto de Varsóvia, torna-se rico e proprietário de um obscuro entreposto comercial de diversos produtos. Fica a sensação que Karol Karol cada vez mais utiliza métodos anti-éticos para se enriquecer, tecendo assim um paralelo com aquela atualidade polonesa pós queda do Muro de Berlim. Kiéslowski trabalha uma maneira amoral nesta progressão econômica do personagem Karol Karol, mas não tira o peso sobre o desejo de igualdade que não acontecera com o julgamento ocorrido ainda no começo da história. Esta igualdade se assemelha a uma vingança do protagonista pelas dores causadas por Dominique (Julie Delpy), sua ex-esposa francesa. No caso, utilizei esta construção de desejo por igualdade na progressão dramática da personagem Cristiane, a ré que Deolinda julgará. Cristiane imagina que constrói sua igualdade em relação aos outros de classe social mais alta, com quem ela convive em seu papel como empregada doméstica e babá de um magnata.

Segundo - Existem alguns aspectos formais de construção de cenas em $A$ Igualdade é Branca que são referencias para algumas cenas de "Deolinda". O filme também se passa num espaço de tribunal e, para tanto, há referências de enquadramento e cadência do filme que são incorporados no episódio proposto. Cristiane, a ré em Deolinda, chora no final como Karol Karol chora ao adentrar a prisão feminina onde está detida Dominique. Cristiane, ao estourar as garrafas com tiros, tem uma reação próxima a de Karol Karol quando ele observa os gradis de seu pente de cabelos. Deolinda caminha no corredor da faculdade de maneira hesitante 
e de maneira próxima com que Karol Karol caminha numa calçada para ir ao tribunal.

A referência com o capítulo $V$ do Decálogo se dá através do tecer de hipóteses motivacionais com as quais o jovem Jacek Lazar (Miaroslav Baka) teria matado o taxista Waldemar Rekovski (Jan Tesarz). Em "Deolinda", fica a expectativa em saber porque Cristiane cometeu um crime tão bárbaro. Para os capítulos I e VIII do Decálogo ficam diálogos formais. No começo do primeiro capítulo, há um personagem que percorre todos os capítulos da série, mas não interage com nenhum outro personagem, ele olha para o espectador. Este recurso utilizo em "Deolinda" para as personagens da juíza e de Cristiane. No ínterim do capítulo VIII da série "O Decálogo", a professora que leciona sobre o processo do Holocausto Judeu na Segunda Guerra é interpelada num ambiente universitário. Para o episódio "Deolinda", fica o diálogo formal nas cenas em que há o retrato do espaço de uma tradicional faculdade de Direito.

Partindo destas experiências nas obras fílmicas e televisivas de Kiéslowski e como também eu não consegui conversar com Luislinda para roteirizar alguma história de sua vida; eu imaginei como seria a história de uma juíza negra julgar uma ré também negra. Partindo de casos extremamente violentos nos quais os autores dos crimes se tornaram vilões midiáticos, eu imaginei como e porque uma mulher negra poderia se tornar uma espécie de vilã também midiática.

Na referência para construção destas personagem está o livro "Pele Negra e Máscaras Brancas". Em seu capítulo 3, denominado "A mulher negra e o branco", 
Fanon discorre a subalternidade das personagens escritas por Mayotte Capécia (1916 - 1955), em seu livro "Je suis Martiniquoise". Na análise, em linhas gerais, Fanon destaca que a personagem feminina de Mayotte despreza os negros de sua terra martinicana além de desdenhar a cultura deste local. Sua personagem tem o desejo de viver na capital francesa e, para tanto, torna-se cônjuge de um francês que atua no exército. Na crítica, Fanon diz que a personagem toma pra si a problemática em não se adaptar no território colonizador. Há vários significados nisto, do corpo a ser colonizado, exercer o poder através da entrega ao amor e da presunção de assimetria nessa relação colonizador e colonizado. É uma relação de encontro, mas ao mesmo tempo de necessidade ao se manter a assimetria dos lugares ocupados pelo colonizador e colonizada.

Mayotte ama um Branco de quem ela aceita tudo. É seu senhor. Ela não reclama nada, não exige nada senão um pouco de brancor em sua vida. E quando a questionam para saber se ele é belo ou feio, ela amorosamente dirá: Tudo que sei, é que ele tinha os olhos azuis, os cabelos louros, a tez pálida e que eu o amava, - é fácil de se ver se remetermos os termos aos seus devidos lugares, quando se obtém algo próximo disso: "Eu o amava porque ele tinha os olhos azuis, os cabelos louros e a tez pálida. E nós, que somos antilhanos, nós somente sabemos muito: o negro tem medo dos olhos azuis. (Fanon, 1975$, p. 34$)^{8}$

O que Fanon coloca em sua análise, diz muito sobre o quanto o desejo de ascensão está ligada a manter uma relação de subalternidade. Na minha história de vida, percebo que muitas vezes o corpo da mulher negra significa também esse

\footnotetext{
${ }^{8}$ Mayotte aime un Blanc dont elle accepte tout. C'est le seigneur. Elle ne réclame rien, n'exige rien, sinon un peu de blancheur dans sa vie. Et quand, se posant la question de savoir s'il est beau ou laid, l'amoureuse dira: "Tout que je sais, c'est qu'il avait les yeux bleus, les cheveux blonds, le teint pâle, et que je l'aimais", - il est facile de voir, en remettant les termes à leur place, qu'on obtient à peu près ceci: “Je l'aimais parce qu'il avait les yeux bleus, les cheveux blonds et la teint pâle". Et nous qui sommes Antillais, nous ne le savons que trop: le nègre craint les yeux bleus, répète-t-on là-bas. (Fanon, 1975. p. 34)
} 
território a ser colonizado. Na relação que se estabelece, a subalternidade é um elemento de poder. A mulata do carnaval exerce esse poder da sedução, por exemplo. Estar com um homem branco pode significar passaportes na ascensão da pessoa negra. Nesta relação de desiguais, vejo que esta ideologia aprisiona e garante a relação de poder. Neste sentido, há um poema da Escritora e Atriz Elisa Lucinda que dialoga efetivamente com este contexto.

"Mas que nega linda

E de olho verde ainda

Olho de veneno e açúcar!

Vem nega, vem ser minha desculpa

Vem que aqui dentro ainda te cabe

Vem ser meu álibi, minha bela conduta

Vem, nega exportação, vem meu pão de açúcar!

(Monto casa procê mas ninguém pode saber, entendeu meu dendê?)

Minha tonteira minha história contundida

Minha memória confundida, meu futebol, entendeu meu gelol?

Rebola bem meu bem-querer, sou seu improviso, seu karaoquê;

Vem nega, sem eu ter que fazer nada. Vem sem ter que me mexer

Em mim tu esqueces tarefas, favelas, senzalas, nada mais vai doer. Sinto cheiro docê, meu maculelê, vem nega, me ama, me colore Vem ser meu folclore, vem ser minha tese sobre nego malê.

Vem, nega, vem me arrasar, depois te levo pra gente sambar."

Imaginem: Ouvi tudo isso sem calma e sem dor.

Já preso esse ex-feitor, eu disse: "Seu delegado..."

E o delegado piscou.

Falei com o juiz, o juiz se insinuou e decretou pequena pena

com cela especial por ser esse branco intelectual...

Eu disse: "Seu Juiz, não adianta! Opressão, Barbaridade, Genocídio nada disso se cura trepando com uma escura!"

Ó minha máxima lei, deixai de asneira

Não vai ser um branco mal resolvido

que vai libertar uma negra:

Esse branco ardido está fadado

porque não é com lábia de pseudo-oprimido

que vai aliviar seu passado. 
Olha aqui meu senhor:

Eu me lembro da senzala

e tu te lembras da Casa-Grande

e vamos juntos escrever sinceramente outra história

Digo, repito e não minto:

Vamos passar essa verdade a limpo

porque não é dançando samba

que eu te redimo ou te acredito:

Vê se te afasta, não invista, não insista!

Meu nojo!

Meu engodo cultural!

Minha lavagem de lata!

Porque deixar de ser racista, meu amor, não é comer uma mulata!"

(Elisa Lucinda, www.escolalucinda.com.br)

Tendo estes significados em ascensão, tracei um paralelo entre as personagens Deolinda e Cristiane. Nas suas trajetórias distintas, elas se relacionaram com homens que detém poder e, não por acaso, significam retratos de embranquecimento (trabalhado no personagem professor de Deolinda) ou de branquitude (como no personagem herdeiro da maior mineradora do Brasil). Eles são brancos ou então conseguem dialogar em sua branquidade como signo de poder.

No roteiro do episódio "Deolinda", há um feixe de acontecimentos no qual as histórias das personagens se entrecruzam em passado e presente, recurso semelhante que Kiéslowski utilizou em "A Fraternidade é Vermelha”. Neste paralelo, não há interação de Deolinda e Cristiane anterior ao julgamento, mas as suas histórias são vivenciadas, independentemente das suas realidades sociais, através de relações amorosas com sentidos de ascensão. Neste passado e presente retratados, temos a história de Deolinda, já senhora de 54 anos, trabalhando como 
juíza e também Deolinda ainda jovem, por volta dos 23 anos, nos tempos de sua graduação numa faculdade tradicional de Direito. Nesta estrutura passado/presente, temos a história de Cristiane que aos 24 anos desfila como rainha da bateria de uma grande escola de samba paulistana e trabalha como doméstica na residência do herdeiro da maior mineradora do Brasil; e que atualmente aos 29 anos está detida em regime fechado numa penitenciária feminina e aguarda julgamento para o caso em que ela é a ré por ter assassinado seu patrão.

Durante a graduação na Faculdade de Direito, Deolinda lidou com diversos dilemas na sua convivência acadêmica acerca dos significados de seu corpo e de seu rosto negros. Sendo a única mulher negra na faculdade de Direito no final dos anos 70 e começo dos anos 80, Deolinda desenvolve uma relação amorosa com a única pessoa que demonstra desejo por ela, no caso seu professor de Direito Penal, Emílio de 48 anos. Este professor pode ser considerado negro ou branco dependendo das circunstâncias; sua pele clara e seus cabelos crespos significam este duplo. Emílio vive uma relação marital com uma mulher branca, os dois tem um filho já adolescente. No entanto, Emílio diz a protagonista que ele vive um momento de desquite ou separação porque ama Deolinda.

Deolinda se angustia cada vez mais pela relação desigual que vivencia com seu professor. Isto vai além de seu sentimento ao se enxergar como amante dele; o que a perturba é o que ela significa nesta relação amorosa. Deolinda percebe que Emílio deseja exercer o duplo relacionamento, mantendo-a no lugar de amante em que ela ocupa. Talvez faça sentido para ele o desejo colonizador. Na formatura de Deolinda, ela tem o desejo de matar seu professor namorado, mas ela se demove 
deste sentimento. Para transformar este lugar em que ela está e ocupa, ela deverá compreender sua jornada e os significados dela.

Aos 24 anos, Cristiane se enxerga como uma mulher bonita e desejada. Sua visibilidade como rainha da bateria da escola de samba em que frequenta favorece esse olhar sobre si mesma. Mas o olhar de Alberto, seu patrão, sobre a jovem neste novo papel exercido por ela como mulata de carnaval, é um passaporte para que ela se compreenda como mulher possível para estar junto ao que ele significa. $\mathrm{Na}$ história do episódio, Alberto é herdeiro do dono da maior mineradora do Brasil e tem formação em faculdade fora do país.

Alberto está recém separado e curte suas oportunidades de solteiro. Cristiane, enxergando-se como mulher possível diante das investidas de Alberto, almeja uma relação estável ou marital com seu patrão. Alberto entende a relação com Cristiane como uma atração física que se resolve em relação sexual quando o desejo lhe aflora. Ele detém o poder. Mas para imagem dele e da empresa pela qual ele é herdeiro, o mais efetivo é que ele tenha os flashes fotográficos de colunas sociais ao lado de uma modelo loira ou branca. Para Cristiane fica questões sobre os impedimentos daquilo que ela significa em seu corpo e rosto não ser possível numa relação de igualdade com Alberto. Esses mesmos impedimentos afloram em Cristiane o desejo de justiça no qual ela remói a necessidade de quebrar o espelho narcísico em que ela se projetava dentro da relação estabelecida com Alberto. Cristiane resolve atirar em Alberto numa última conversa entre os dois, mas além do tiro acertar o patrão dentro do carro dele, um outro acerta o tanque de combustível e o veículo explode com o Alberto e seu filho de 4 anos, que está no banco traseiro. 
Cristiane, agora autora de um crime, sai da representação da mulata para ser a vilã midiática inconteste.

Os caminhos paralelos das personagens vão revelando a humanidade de Deolinda ao não suportar a relação estabelecida e também revela a humanidade de Cristiane que compreende o ocorrido e o que realmente estava em jogo no que ela significa como mulher negra. Numa visão cristã dividida entre bem e mal, convido o espectador a refletir sobre a questão da representação da mulher negra caminhando em circunstancias complexas em que o humano se relaciona através de seu todo, com seu "bem" e com seu "mal". Ao final, a declaração de Cristiane diante do tribunal aproxima finalmente as duas personagens em suas condições humanas nas sociedades em que vivem.

\section{Conclusão}

Para construir estas dramaturgias audiovisuais da série televisiva/telefilme "Menina Mulher da Pele Preta" e outras que acabaram saindo deste processo de mestrado (como a série televisiva "Sociedade Anônima" que tem seu piloto roteirizado e apresentado como anexo a esta dissertação), foi necessário realizar este movimento simbólico de demolição para posterior construção de sentidos não recorrentes em nosso audiovisual. Ao analisar obras audiovisuais atuais que retrataram espaços e pessoas da periferia como Cidade de Deus, Cidade dos Homens, Turma do Gueto, Natália, Bróder, entre outros; meu intuito não foi desconsiderá-las totalmente em nome de uma nova dramaturgia que proponho através dos roteiros escritos neste mestrado. O que fica, de fato, diante da 
recorrência de certos retratos e atribuições a pessoa negra nessas obras, é a necessidade de compreendê-las a luz da atualidade dos exercícios de nossa branquitude.

Diante de questões que julgo ainda estar invisíveis em nosso audiovisual, propor uma série televisiva como "Menina Mulher da Pele Preta" é trazer a atualidade das disputas em nossa sociedade que estão balizadas na negociação, afirmação ou negação de nossa herança negra ou aquela não branca civilizatória europeia (se nos referenciarmos ao ideário civilizatório embranquecedor do início do século XX no Brasil). Não bastaria trazer uma dramaturgia que contemplasse somente a presença de uma protagonista negra, assim como foi feito na Novela Viver a Vida (2010, Rede Globo, escrita pelo autor Manoel Carlos) ao trazer a atriz negra Taís Araújo para estrelar nesta obra. Há que se compreender qual é a qualidade desse protagonismo diante de nosso processo histórico embranquecedor e de nossa atualidade enquanto exercício da branquitude.

Ao me debruçar sobre as produções audiovisuais citadas e correlacioná-las a minha experiência na Graduação em Audiovisual pela USP, tentei compreender o quanto as sutilezas das nossas discriminações são tão agudas e contundentes. Nelas estão muitas vezes os exercícios da normalidade da nossa branquitude. E quando discorro sobre a branquitude, não é num sentido de apontar quem a exerce, mas sim para entender o porque, todos nós, brasileiros (brancos, negros, índios, orientais), exercemos de alguma forma esta ideologia. Assim, eu afirmo que tanto retratos positivos quanto negativos da pessoa negra são carregados de sentidos que aprisionam a representação da cultura, do corpo e do rosto negro tal qual a 
necessidade de assegurar este lugar na nossa sociedade; como uma eterna visita a nossa relação entre colonizador e colonizado tão bem exposta e esmiuçada por Frantz Fanon, por exemplo.

Esta dissertação é fruto também do Cinema de Quebrada paulistano, nos quais as obras como Videolência, (2009, do Núcleo de Comunicação Alternativa); Amanhã Talvez (2009, Rogério Pixote - CineBecos) e Panorama Arte na Periferia (2007, Peu Pereira e David Vidad) entre outros; mostram um caminho muito importante no nosso audiovisual no qual os "eternos" retratados de nosso subdesenvolvimento agora têm voz e articula discursos audiovisuais que questionam alguns lugares comuns de nossa sociedade. Aqui não estou segurando bandeiras que tragam uma fórmula mágica dramatúrgica que atenda soluções de nosso mercado cinematográfico ou mesmo me punindo ao não apresentar soluções para o nosso cinema subdesenvolvido (Paulo Emílio Sales Gomes). Penso que a Globo Filmes já se encarrega disto com filmes como Assalto ao Banco Central (2011, Direção: Marcos Paulo), Cilada.com (2011, Direção: José Alvarenga Junior) e Se eu fosse Você 2 (2010, Direção: Daniel Filho). Com esta dissertação, ofereço o resultado de um caminho resultante da interlocução entre periferia, negro e universidade. Nós, da quebrada, somos capazes de fazer um cinema no qual sabemos bem o que queremos e como faremos nosso discurso audiovisual; por mais que seja interessante categorizar o cinema de quebrada como ingênuo na utilização técnica de luz, som e narrativa (como acontece em Oficinas Kinoforum). Está o embate político, pois o Cinema de Quebrada apresenta sua capacidade intelectual e técnica para se realizar um audiovisual que dialoga com inúmeras questões da nossa sociedade. 
Trazer referências como a filmografia de Krzysztof Kiéslowski e cineastas iranianos como Jafar Panahi, Mohsen Mahkmalbaf e Abbas Kiarostami para a dramaturgia apresentada em "Menina Mulher da Pele Preta", é uma forma de compreender a humanidade de seus retratos e de suas perspectivas naquilo em que suas culturas os formam e são traduzidas cinematograficamente para outros que venham a se identificar com suas questões, mesmo num outro contexto como o brasileiro em suas especificidades.

Esta dissertação tenta compreender os diversos nãos que a motivaram pra propor o dizer sim a histórias de vida, negras e periféricas, que também constroem o lugar universitário e audiovisual em seu saber e em seu conhecimento. Ao contrário do que vivenciei em minha graduação em que meu conhecimento indicava diversas formas de não fazer parte da universidade, ao contrário do retrato do negro que quase sempre evidenciou nossas inadequações civilizatórias ou exotizantes; aqui eu trago minha contribuição naquilo em que conheço e em que burilo, como um artesão que talha na história sentidos ancestrais para o mundo e para nossos tempos.

\section{Bibliografia}

ARAÚJO, Joel Zito. A Negação do Brasil. 1998. Editora SENAC/São Paulo. São Paulo.

BHABHA, Homi. The Location of Culture. 1994. Editora Routledge. Nova lorque.

BENTES, Ivana. Estéticas da Violência no Cinema. 2003. Rio de Janeiro. Interseções: Revista de Estudos Interdisciplinares, pág. 217-237.

BENTO, Maria Aparecida Silva. Pactos Narcísicos no racismo: branquitude e poder nas organizações empresariais e no poder Público. Cidadania em Preto e Branco, 
discutindo as relações raciais. 1998. Editora Ática. São Paulo

BORDWELL, David. Narración de un film de ficción. 1985. Editora Paidós. Londres.

BRECHT, Bertolt. Teatro Completo. 12 Volumes. Editora Paz e Terra, 1990. Rio de Janeiro.

CHION, Michel. O roteiro de cinema. 1989. Editora Martins Fontes. São Paulo.

FANON, Frantz. Los condenados de la Tierra. 1983. Edição nº7. Editora Fondo de Cultura Económica. Ciudad del México.

FANON, Frantz. Peau Noir, Masques Blancs. 1975. Editora Éditions du Sueil. Paris.

FANON, Frantz. Pele Negra, Máscaras Brancas. 2008. Editora UFBA. Salvador

FANON, Frantz. Piel Negra, Máscaras Blancas. 1973. Editora Abraxas. Buenos Aires.

FERNANDES, Florestan. O Negro no Mundo dos Brancos. 1972. Editora Difusão Europeia do Livro. São Paulo.

FIELD, Syd. Manual do roteiro: os fundamentos do texto cinematográfico. 2001. Editora Objetiva. Rio de Janeiro.

FRANKENBERG, Ruth. White Women, Race Matters: The Social Construction of Whiteness. 1993. Editora: University of Minesota Press. Minneapolis.

FREIRE, Marcelino. Rasif - Mar que Arrebenta. 2008. Editora: Record. São Paulo.

FREYRE, Gilberto. Casa Grande \& Senzala: Formação da família brasileira sob o regime de economia patriarcal. 1958. Editora José Olympio. Rio de Janeiro.

GUIMARÃES, Antônio Sérgio Alfredo. Classes, Raças e Democracia. 2002. Editora 34. São Paulo.

HALL, Stuart. Da diáspora - Identidades e Mediações Culturais. Editora UFMG. 2003. Belo Horizonte.

HAMBURGER, Esther Império; Ananda Stücker e Guilherme de Cerqueira César. "Políticas da representação: interações audiovisuais nas quebradas" CD de Resumo dos trabalhos do X Encontro Anual da Sociedade de Estudos de Cinema - SOCINE, Ouro Preto, MG, 2006.

HAMBURGER, Esther Império; Ananda Stücker, Laura Carvalho Hércules, Miguel Antunes Lemos. Inclusão Social e Política das representações no cinema e na televisão - Relatório Projeto Rede de Telas, FAPESP, SP, 2009.

HAMBURGER, Esther Império. Da política a poética de certas formas audiovisuais. 2009. Tese de Livre Docência. ECA/USP. São Paulo. 
HELMS, Janet E. Black and White racial identity: Theory, research, and practice. Contributions in Afro-American and African studies. 1990. Editora Greenwood. Edmonton.

HOLANDA, Sérgio Buarque de. Raízes do Brasil. 1998. Editora Companhia das Letras. São Paulo.

HOWARD, David e Mabley Edward. Teoria e prática do roteiro: um guia para escritores de cinema e televisão com análises de 16 filmes famosos. 1996. Editora Globo. São Paulo.

JESUS, Carolina Maria de. Quarto de Despejo: diário de uma favelada. Edição n9. 2010. Editora Ática. São Paulo.

LEWELLEN, Ted C. Political Anthropology - An Introduction. 2003. Editora: Greenwood. Edmonton.

LUANDO, Luan. Denegri. www.tutuliterario.blogspot.com

LIMA, Renato Candido de. Sociedade Anônima: O Protagonismo Negro na Teledramaturgia Brasileira. 2007. Trabalho de Conclusão de Curso CTR/ECA/USP. São Paulo.

LUCINDA, Elisa. Mulata Exportação. www.escolalucinda.com.br

MBEMBE, Achille. As Formas Africanas de Auto Inscrição. In: Revista Estudos AfroAsiáticos, Ano 23, $n^{\circ}$ 1. 2001. São Paulo.

MELO, Cristina. Representação da Periferia e do Centro em Cidade Dos Homens. In: Anais do XXIX Congresso Brasileiro em Ciências da Comunicação. 2006. São Paulo. Site: http://www.intercom.org.br/papers/nacionais/2006/lista resumos.htm

MOREIRA, Roberto Franco. Deus Contra Todos. Tese de Doutoramento. 2001. Escola de Comunicações e Artes da Universidade de São Paulo. São Paulo.

MUNANGA, Kabengele. Estratégias e políticas de combate à discriminação racial. 1996. Editora Edusp/Estação Ciência. São Paulo.

PIZA, Edith. Porta de vidro: uma entrada para branquitude. In: CARONE, Iray; BENTO, Maria Aparecida da Silva (orgs.). Psicologia Social do racismo: estudos sobre branquitude e branqueamento no Brasil. p. 59-90. 2002. Editora Vozes. Petrópolis.

SANTIAGO, Silvana. Tal Conceição, Conceição de Tal. Classe, gênero e raça no cotidiano de mulheres pobres no Rio de Janeiro das primeiras décadas republicanas. 2006. Tese de Mestrado. Ifch-Unicamp. Campinas.

SARAIVA, Leandro e CANNITO, Newton. Manual de roteiro: ou manuel, o primo pobre dos manuais de cinema e TV. 2004. Conrad Editora do Brasil. São Paulo. 
SEYFERTH, Giralda. et alii. Mundos em Movimento: Ensaios Sobre Migrações. 2007. Editora Universidade Federal de Santa Maria. Santa Maria.

SHOHAT, Ella e STAM, Robert. Crítica da Imagem Eurocêntrica. 2006. Cosac Naify. São Paulo.

SILVA, Ana Paula da. Pelé e o complexo de Vira-Latas. Tese de Doutoramento. 2008. Universidade Federal do Rio de Janeiro - Instituo de Filosofia e Ciências Sociais. Rio de Janeiro.

SILVA, Lunalva de Oliveira Mendes. A representação do negro e das relações raciais nos meios de comunicação: Um estudo comparativo em revistas de segmentos, do Grupo Abril, no Brasil e suas respectivas versões norte-americanas. Monografia. 2011. Escola de Comunicações e Artes da Universidade de São Paulo. São Paulo.

SOUZA, Elizandra (Mjiba). A primeira vez que fui ao céu. In: Um Segredo no Céu da Boca, ROSA, Alan da et alii. 2008. Edições Toró. Taboão da Serra.

SOUZA, Elizandra (Mjiba) e KINTE, Akins. Punga. 2008. Edições Toró. Taboão da Serra.

STANISLAVSKI, Constantin. A Construção do Personagem. 1998. Editora Civilização Brasileira. Rio de Janeiro.

STANISLAVSKI, Constantin. A Criação de um Papel. 1998. Editora Civilização Brasileira. Rio de Janeiro.

STÜCKER, Ananda. A Periferia nos Seriados Televisivos Antônia e Cidade dos Homens. 2009. Tese de Mestrado. PPGCOM ECA/USP. São Paulo

TATUM, Beverly Daniel. Why are all the Black kids sitting together in the cafeteria?. 1997. Editora Basic Books. Nova York.

TEIXEIRA, Moema de Poli. Negros na Universidade. 2003. Editora Pallas. Rio de Janeiro.

VAZ, Sérgio. O Colecionador de Pedras. 2007. Editora Global. São Paulo.

VEJA. Revista Hebdomadário. In: Revista Veja, 13 de Novembro de 2002 http://veja.abril.com.br/131102/p 146.html

WALKER, Alice. De Amor e Desespero. Edição n¹. 1998. Editora Rocco. São Paulo.

\section{Referências Audiovisuais}


Amanhã Talvez. Filme Curta Metragem. Direção: Rogério Pixote. 2009

Antônia. Filme. Direção: Tata Amaral. Filme. 2006.

Antônia. Série Televisiva. Direção: Vários. Rede Globo. 2006-2007.

Aqui Agora. Telejornal. Produção: Sistema Brasileiro de Televisão. 1990 a 1996.

Aruanda. Documentário. Direção: Linduarte Noronha. 1960

Assalto ao Banco Central. Filme. Direção: Marcos Paulo. 2011.

Atitude. Programa de TV (piloto. Direção: Renato Candido e Paula Silva. Produção: ECA/USP. 2003

Através das Oliveiras. Filme. Direção: Abbas Kiarostami. 1994.

O Balão Branco. Filme. Direção: Jafar Panahi. 1995.

Barravento. Filme. Direção: Glauber Rocha. 1962.

Besouro. Filme. Direção: João Daniel Tikomiroff. 2009.

Bróder. Filme. Direção: Jeferson De. 2011.

Cafundó. Filme. Direção: Paulo Betti. 2005.

Carandiru. Filme. Direção: Hector Babenco. 2003.

Cidade de Deus. Filme. Direção: Fernando Meirelles. 2003.

Cilada.com. Filme. Direção: José Alvarenga Júnior. 2011

Cidade dos Homens. Série Televisiva. Direção: Vários. Rede Globo. 2003-2006.

Cinco Vezes Favela. Filme. Direção: León Hirszman, Joaquim Pedro de Andrade, Cacá Diegues, Miguel Borges e Marcos Frias. 1961.

Cinco Vezes Favela, Agora por nós mesmos. Filme. Direção: Cacau Amaral, Cadu Barcelos, Luciana Bezerra, Luciano Vidigal, Manaíra Carneiro, Rodrigo Felha e Wagner Novaes.

Contra Todos. Filme. Direção: Roberto Moreira. 2004.

Dama do Lotação. Filme. Direção: Neville de Almeida. 1978.

O Decálogo. Série Televisiva. Direção: Krzysztof Kieslowski. 1988. Polônia. 
Dona Flor e Seus Dois Maridos. Filme. Direção: Bruno Barreto. 1976

A Fraternidade é Vermelha. Filme. Direção: Krzysztof Kiéslowski. 1994. FrançaPolônia.

Os Dois Filhos de Francisco. Filme. Direção Breno Silveira. 2006.

Eles Não Usam Black Tie. Filme. Direção: León Hirszman. 1981.

A Igualdade é Branca. Filme. Direção: Krzysztof Kiéslowski. 1994. França-Polônia. Jennifer. Filme. Direção: Renato Candido. 2011

Manos e Minas. Programa de TV. Produção: TV Cultura. 2008-2011

Moro na Tiradentes. Filme. Direção: Henri Gervaiseau. 2007.

O Nascimento de uma Nação. Filme. Direção: D.W. Griffith. 1913

Natália. Série Televisiva. Direção: Vários. TV Brasil. 2011.

A Negação do Brasil. Filme. Direção: Joel Zito Araújo. 2000.

Negrodrama. Filme. Direção: Tio Pac. 2008.

Notícias de uma Guerra Particular. Filme. Direção: João Moreira Salles. 1999.

Ônibus 174. Filme. Direção: José Padilha. 2003.

Orfeu Negro. Filme. Direção: Marcel Camus. 1959.

Orí - Consciência Negra. Filme. Direção: Raquel Gerber. 1986.

Os 12 Trabalhos. Filme. Direção: Ricardo Elias. 2008.

Quanto Dura o Amor. Filme. Direção: Roberto Moreira. 2009

Quase Dois Irmãos. Filme. Direção: Lúcia Murat. 2005.

Panorama Arte na Periferia. Documentário. Direção: Peu Pereira e David Vidad. 2007

Proibido Proibir. Filme. Direção: Jorge Durán. 2006.

Rio Zona Norte. Filme. Direção: Nelson Pereira dos Santos. 1957

Saneamento Básico. Filme. Direção: Jorge Furtado. 2007 
São Paulo S/A. Filme. Direção: Luís Sérgio Person. 1965.

Se eu fosse você 2. Filme. Direção: Daniel Filho. 2010.

O Silêncio. Filme. Direção: Mohsen Mahkmalbaf. 1998.

Sinhá Moça. Filme. Direção: Tom Payne. 1953.

Última Parada 174. Filme. Direção: Bruno Barreto. 2009.

Uma Onda no Ar. Filme. Direção: Helvécio Ratton. 2002.

Videolência. Direção: Núcleo de Comunicação Alternativa. 2009.

Viver a Vida. Novela. Produção: Rede Globo. Autor: Manoel Carlos. 2010.

Tropa de Elite. Filme. Direção: José Padilha. 2007.

Tropa de Elite 2. Filme. Direção: José Padilha. 2010.

Turma do Gueto. Série Televisiva. Direção: Vários. Rede Record. 2002-2005.

\section{Referencias Fonográficas}

Mundo Bom. Agepê. LP Tipo Exportação. 1977. Gravadora Continental. 